\title{
AVALIAÇÃO DA CONCENTRAÇÃO DE FLÚOR NA ÁGUA DE ABASTECIMENTO PÚBLICO DE BAURU, ANTES E DEPOIS DOS PROCEDIMENTTOS DE
}

FLUORETAÇÃO

\section{IRENE RAMIRES}

Dissertação apresentada à Faculdade de Odontologia de Bauru, Universidade de São Paulo, como parte dos requisitos para a obtenção do título de Mestre em Odontologia, área de concentração, Saúde Coletiva.

(Edição Revisada) 


\section{AVALIAÇÃO DA CONCENTRAÇÃO DE FLÚOR NA ÁGUA DE ABASTECIMENTO PÚBLICO DE BAURU, ANTES E DEPOIS DOS PROCEDIMENTOS DE}

FLUORETAÇÃO

IRENE RAMIRES

Dissertação apresentada à Faculdade de Odontologia de Bauru, Universidade de São Paulo, como parte dos requisitos para a obtenção do título de Mestre em Odontologia, área de concentração, Saúde Coletiva.

(Edição Revisada)

Orientadora: Profa. Dra. Marília Afonso Rabelo Buzalaf

Co-Orientador: Prof. Dr. José Roberto Pereira Lauris 


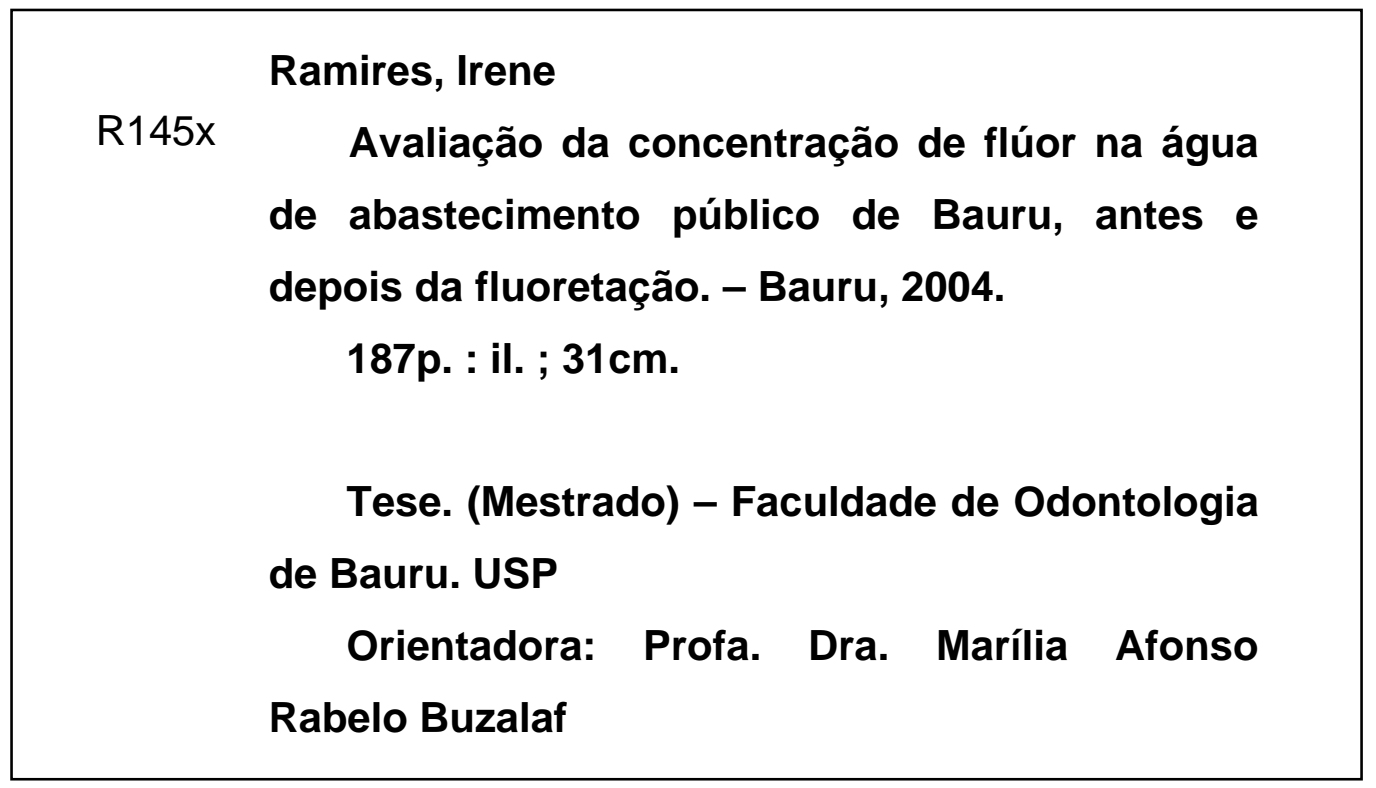

Autorizo, exclusivamente para fins acadêmicos e científicos, a reprodução total ou parcial desta dissertação/tese, por processos fotocopiadores e/ou meios eletrônicos.

Assinatura:

Data: 1

Comitê de Ética da FOB: Projeto de pesquisa aprovado em 21 de outubro de 2002. 


\section{IRENE RAMIRES}

08 de Novembro de 1962

Nascimento

Lucianópolis - SP

Filiação

Antonio Ramires

Iracy Ransi Ramires

1981-1985

Curso de Odontologia - Faculdades

Integradas de Uberaba - Uberaba MG.

1992

Curso de Pós-Graduação em Dentística Restauradora, em Nível de Especialização, na Faculdade de Odontologia de Bauru, USP.

1993

Curso de Pós-Graduação em Ajuste Oclusal, em Nível de Aperfeiçoamento, no Centro de Estudos Odontológicos de Bauru.

2001

Curso de Pós-Graduação em Odontologia em Saúde Coletiva, em Nível de Aperfeiçoamento, na Associação Paulista de CirurgiõesDentistas de Bauru.

$2001-2002$

Curso de Pós-Graduação em Odontologia em Saúde Coletiva, em Nível de Especialização, na Associação Paulista de CirurgiõesDentistas de Bauru.

$2003-2004$

Curso de Pós-Graduação em Odontologia em Saúde Coletiva, em Nível de Mestrado, na Faculdade de Odontologia de Bauru, USP. 
ASSOCIAÇÕES

APCD - Associação Paulista de

Cirurgiões-Dentistas

CRO - Conselho Regional de Odontologia do Estado de São Paulo

SBPqO - Sociedade Brasileira de Pesquisas Odontológicas 


\section{DEDICATÓRIA}

Àqueles que mais amo,

Meus avós Ana e José, que tanto me ensinaram e continuam a fazê-lo.

Meus pais Iracy e Antonio, pelo amor, carinho, dedicação e compreensão com que me criaram, ensinando que os obstáculos e dificuldades devem ser encarados como um desafio a ser transposto com dedicação, seriedade e acima de tudo muita dignidade.

Meu irmão José Patrício, carinhoso em todos os momentos, sempre preocupado comigo e disposto a me ouvir e ajudar, meu melhor amigo.

Minhas sobrinhas Isabella e Giovanna, minhas adoradas meninas que me trazem tanta alegria.

Meus filhos Ana Laura e José Guilherme, tudo de melhor e mais importante que a vida poderia me dar, que tanto me ajudam entendendo minhas ausências. Presentes de DEUS. 


\section{AgRADECIMENTOS}

À Professora Dra. Marília Afonso Rabelo Buzalaf, orientadora desta dissertação, pela confiança e liberdade com que conduziu a orientação, pelas sugestões de aprimoramento e tempo dedicado.

Ao Professor Dr. José Roberto Pereira Lauris, co-orientador desta dissertação, que com poucas palavras, me disse tanto. Sua serenidade e seriedade serão sempre lembrados.

À Professora Dra. Maria Fidela de Lima Navarro, por ter me orientado a seguir o caminho da Saúde Coletiva.

Ao Professor Dr. José Roberto de Magalhães Bastos, por tantas orientações e oportunidades concedidas.

Ao Professor Dr. Jesus Carlos Andreo, por se dispor a me ouvir e orientar em momentos difíceis de incertezas e dificuldades.

Ao Professor Dr. Arsenio Sales Peres e sua esposa Professora Silvia Helena de Carvalho Sales Peres, pela compreensão e respeito.

Ao José Vieira Alves, por toda ajuda e incentivo prestados durante as etapas da pesquisa.

Às amigas de mestrado Aline Guerra Aquilante e Beatriz Simões de Almeida e aos amigos Juliano Pelim Pessan e Eduardo Aleixo Figueira, que tanto participaram deste período da minha vida como verdadeiros amigos.

A todos os demais colegas do mestrado e outros tantos, com os quais partilhei menos intensamente, mas o suficiente para tê-los sempre comigo. 
A todos os funcionários da Faculdade de Odontologia de Bauru, especialmente aos da Biblioteca, Áreas de Concentração de Bioquímica e de Saúde Coletiva, dos quais estive mais próxima, e que de alguma forma colaboraram para que eu pudesse concluir este trabalho.

A todos os voluntários que participaram da pesquisa, sem os quais não seria possível obter as informações necessárias.

Ao Departamento de Água e Esgoto de Bauru, pela colaboração durante a pesquisa. 


\section{TECENDO A MANHÃ}

Um galo sozinho não tece uma manhã:

ele precisará sempre de outros galos.

De um que apanhe esse grito que ele

e o lance a outro; de um outro galo

que apanhe o grito que um galo antes

e o lance a outro; e de outros galos

que com muitos outros galos se cruzem

os fios de sol de seus gritos de galo,

para que a manhã, desde uma teia tênue,

se vá tecendo, entre todos os galos.

E se encorpando em tela, entre todos,

se erguendo tenda, onde entrem todos, se entretendendo para todos, no toldo

(a manhã) que plana livre de armação.

A manhã, toldo de um tecido tão aéreo

que, tecido, se eleva por si: luz balão.

João Cabral de Melo Neto 


\section{SUMÁRIO}

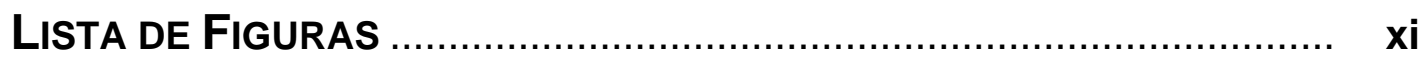

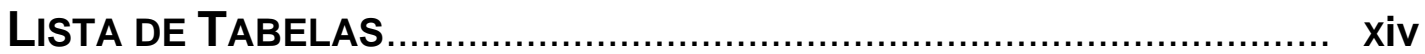

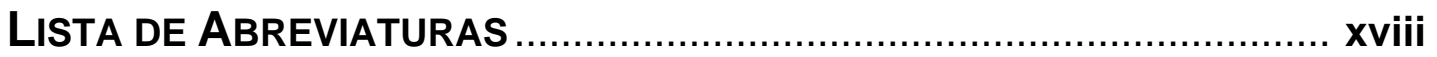

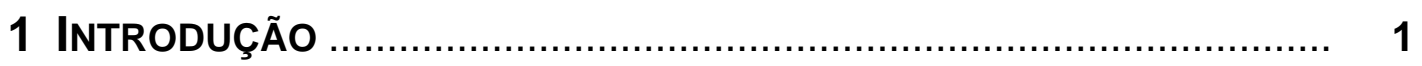

2 REVISÃo dE LiTERATURA $\ldots \ldots \ldots \ldots \ldots \ldots \ldots \ldots \ldots \ldots \ldots \ldots \ldots \ldots \ldots \ldots \ldots . \quad 5$

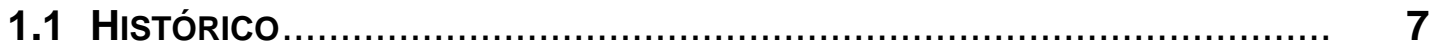

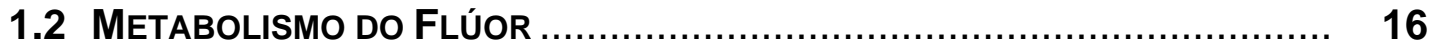

1.3 MECANISMO de AÇÃo do FLÚOR .......................................... 21

1.4 ToxicologIA DO FLÚOR......................................................... 27

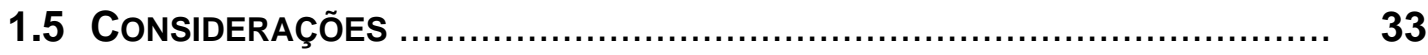

1.6 LEGISLAÇÃO ........................................................................ 45

1.7 A FLUORETAÇÃo No MUNDO ............................................. 51

1.8 A FLUORETAÇÃO NO BRASIL............................................... 63

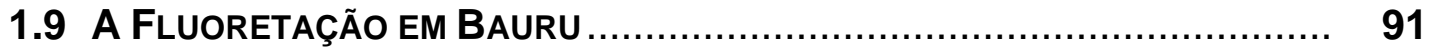

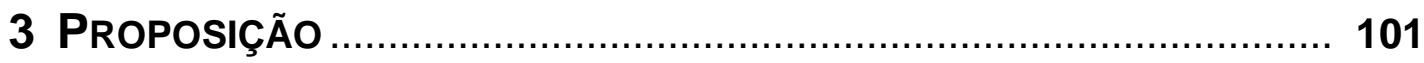

4 Material e Métodos ................................................... 103

4.1 O Sistema de Abastecimento de Água de Bauru...................... 104

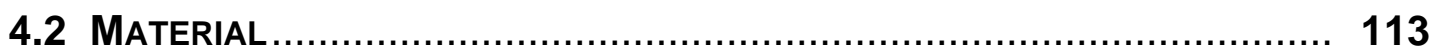

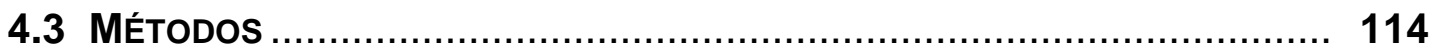

4.3.1 DefiniçÃO DA AMOSTRA .................................................. 115

4.3.2 Pontos de Coleta ....................................................... 118

4.3.3 Responsável Pela Coleta da Amostra ................................ 121

4.3.4 Coleta das Amostras.................................................. 127

4.3.5 AnÁlise Bioquímica de Flúor Presente na ÁGUa .................... 128

4.3.6 ClassificaÇÃo das AMOSTRAS ........................................ 129

4.3.7 ANÁLISE DOS DADOS ...................................................... 131 
5 Resultados

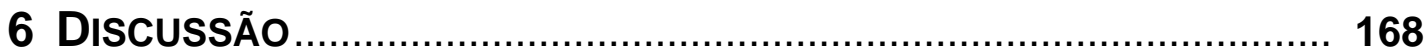

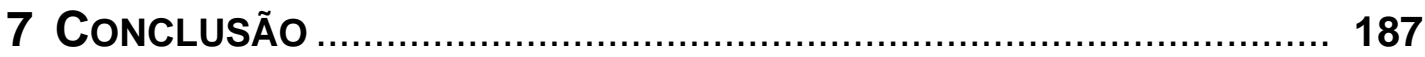

ANEXos

REFERÊNCIAS BIBLIOGRÁFICAS

Abstract

APÊNDICES 


\section{LISTA DE FIGURAS}

FIGURA 1 - Índice CPO-D médio aos 12 anos de idade em 1986 e 1996, segundo macrorregiões brasileiras.

FIGURA 2 - Redução de cárie em Bauru para ambos os gêneros, entre 1976, 1990 e 2001

FIGURA 3 - As bombas dosadoras ficam acopladas a cada um dos tanques contendo ácido fluossilícico e cloro.......................108

FIGURA 4 - Localização dos 19 setores de abastecimento no mapa da cidade de Bauru, 2004

FIGURA 5 - Localização da ETA e dos 27 poços no mapa onde estão definidos os setores de abastecimento da cidade de Bauru, 2004.

FIGURA 6 - Localização dos 63 pontos de coleta das amostras de água em cada um dos setores de abastecimento da cidade de Bauru, 2004 . 120

FIGURA 7 - Todos os poços são mantidos fechados e com entrada é proibida para pessoas estranhas ao DAE 121

FIGURA 8 - Bombas dosadoras e os tanques contendo ácido fluorssilícico e cloro são mantidas em instalações fechadas 122

FIGURA 9 - Instalações com as bombas dosadoras de cloro e flúor...... 122

FIGURA 10 - O uso de equipamentos adequados para abertura da tubulação possibilitando a coleta de água ......................... 123

FIGURA 11 - Ponto de coletada de água na tubulação com água diretamente do poço, antes da fluoretação....................... 123

FIGURA 12 - Folheto informativo com as datas e orientações para proceder a coleta, folheto informativo com orientações de saúde bucal e os frascos para a coleta de água..... 126

FIGURA 13 - Todo material entregue para os voluntários em cada uma das etapas da pesquisa 126

FIGURA 14 - Frascos plásticos de 50 mL usados para a coleta de água..127

FIGURA 15 - Concentração média de flúor na ETA e nos poços, em Bauru no mês de maio de 2003 
FIGURA 16 - Classificação das amostras de água de acordo com a concentração de flúor da ETA e dos poços de Bauru, no mês de maio de 2003.

FIGURA 17 - Concentração média de flúor na ETA e nos poços, em Bauru no mês de agosto de 2003 144

FIGURA 18 - Classificação das amostras de água de acordo com a concentração de flúor da ETA e dos poços de Bauru, no mês de agosto de 2003 144

FIGURA 19 - Concentração média de flúor na ETA e nos poços, em Bauru no mês de novembro de 2003 146

FIGURA 20 - Classificação das amostras de água de acordo com a concentração de flúor da ETA e dos poços de Bauru, no mês de novembro de 2003. 146

FIGURA 21 - Concentração média de flúor na ETA e nos poços, em Bauru no mês de fevereiro de 2004 148

FIGURA 22 - Classificação das amostras de água de acordo com a concentração de flúor da ETA e dos poços de Bauru, no mês de fevereiro de 2004 148

FIGURA 23 - Classificação das amostras de água da ETA e dos poços de acordo com a concentração de flúor, nos meses de maio, agosto e novembro de 2003 e fevereiro de 2004, em Bauru 150

FIGURA 24 - Concentração média de flúor, nos diferentes setores de abastecimento de Bauru, no mês de maio de 2003 155

FIGURA 25 - Classificação das amostras de água de acordo com a concentração de flúor nos diferentes setores de abastecimento de Bauru, no mês de maio de 2003 155

FIGURA 26 - Concentração média de flúor, nos diferentes setores de abastecimento de Bauru, no mês de agosto de 2003 .......... 158

FIGURA 27 - Classificação das amostras de água de acordo com a concentração de flúor nos diferentes setores de abastecimento de Bauru, no mês de agosto de 2003. 158

FIGURA 28 - Concentração média de flúor, nos diferentes setores de abastecimento de Bauru, no mês de novembro de 2003..... 161

FIGURA 29 - Classificação das amostras de água de acordo com a concentração de flúor nos diferentes setores de abastecimento de Bauru, no mês de novembro de 2003 161 
FIGURA 30 - Concentração média de flúor, nos diferentes setores de abastecimento de Bauru, no mês de fevereiro de 2004 ........ 164

FIGURA 31 - Classificação das amostras de água de acordo com a concentração de flúor nos diferentes setores de abastecimento de Bauru, no mês de fevereiro de 2004. 164

FIGURA 32 - Classificação das amostras de água de acordo com a concentração de flúor nos diferentes setores de abastecimento de Bauru, nos meses de maio, agosto e novembro de 2003 e fevereiro de 2004 167 


\section{LISTA DE TABELAS}

TABELA 1 - Após 5 anos de fluoretação, com o levantamento epidemiológico realizado em diferentes datas, o índice CPO-D médio de crianças de 5 a16 anos de idade, em Grand Rapids, Aurora e Muskegon 12

TABELA 2 - Os compostos de flúor mais utilizados na fluoretação da água de abastecimento público no Brasil 34

TABELA 3 - Características da dosagem por via úmida com o ácido fluossilícico, no Brasil, 2003. 37

TABELA 4 - Limite recomendados para a concentração do íon fluoreto em função da média das temperaturas máximas diárias... 38

TABELA 5 - Índice CPO-D médio segundo a idade em escolares. Brasil, 1980, 1986, 1993, 1996.

TABELA 6 - Percentual da população beneficiada com água fluoretada em relação à população total do país, por Estado. Brasil, 1996. 69

TABELA 7 - Percentual da população beneficiada com água fluoretada em relação à população com água tratada, por Estado. Brasil, 1996. 70

TABELA 8 - Percentual da população beneficiada com água fluoretada em relação à população total das capitais. Brasil,1996 ..... 71

TABELA 9 - Percentual da população beneficiada com água fluoretada em relação à população com água tratada e início da fluoretação, nas capitais. Brasil, 1996 ................................ 72

TABELA 10 - Percentual de municípios beneficiados com água fluoretada em relação ao total de municípios do país, por Estado. Brasil 1996 73

TABELA 11 - Percentual de municípios beneficiados com água fluoretada em relação ao total de municípios com água tratada, por Estado. Brasil, 1996. 74

TABELA 12 - Índice CPO-D médio para a idade de 12 anos em algumas cidades quando iniciada a fluoretação e após um período variando entre 7 a 10 anos de fluoretação da água de abastecimento público 93 
TABELA 13 - Índice CPO-D médio para a idade de 12 anos em algumas cidades após 10 anos de fluoretação da água de abastecimento público ....................................................94

TABELA 14 - Redução de cárie em Bauru para ambos os gêneros, entre

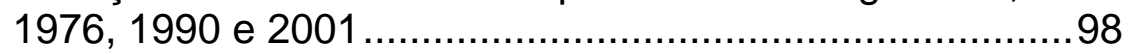

TABELA 15 - Relação dos poços, vazão e ponto de fluoretação. Bauru,

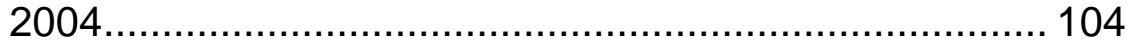

TABELA 16 - Relação dos bairros abastecidos pela Estação de Tratamento de Água (ETA). Bauru, 2004 ........................ 109

TABELA 17 - Relação dos setores, poços, forma de abastecimento e bairros abastecidos pelo DAE. Bauru, 2004 …............... 110

TABELA 17.1 - Relação dos setores, poços, forma de abastecimento e bairros abastecidos. Bauru, 2004 111

TABELA 18 - Pontos de coleta de amostra de água segundo o número e o nome do setor de abastecimento de cada um dos poços, bairro e o número do ponto de coleta 118

TABELA 18.1 - Pontos de coleta de amostra de água segundo o número e o nome do setor de abastecimento de cada um dos poços, bairro e o número do ponto de coleta 119

TABELA 19 - Classificação das amostras de água segundo a concentração de flúor*..... 130

TABELA 20 - Classificação das amostras de água de acordo com a concentração de flúor em $\mathrm{mg} / \mathrm{L}$ 130

TABELA 21 - Concentração de flúor na água da ETA e dos poços antes da fluoretação, no mês de maio, em Bauru, 2003 134

TABELA 22 - Concentração de flúor na água da ETA e dos poços antes da fluoretação, no mês de agosto, em Bauru, 2003 ......... 135

TABELA 23 - Concentração de flúor na água da ETA e dos poços antes da fluoretação, no mês de novembro, em Bauru, 2003 ... 136

TABELA 24 - Concentração de flúor na água da ETA e dos poços, antes da fluoretação, no mês de fevereiro, em Bauru, 2004 ..... 137

TABELA 25 - Concentração de flúor na água da ETA e dos poços, antes da fluoretação, nos meses de maio, agosto e novembro de 2003 e fevereiro de 2004, em Bauru 138 
TABELA 26 - Concentração de flúor na água da ETA e dos poços depois da fluoretação, no mês de maio, em Bauru, 2003.

TABELA 27 - Classificação das amostras de água da ETA e dos poços, de acordo com o teor de flúor, no mês de maio de 2003, em Bauru 141

TABELA 28 - Concentração de flúor na água da ETA e dos poços depois da fluoretação, no mês de agosto, em Bauru, 2003 ......... 143

TABELA 29 - Classificação das amostras de água da ETA e dos poços, de acordo com o teor de flúor, no mês de agosto de 2003, em Bauru 143

TABELA 30 - Concentração de flúor na água da ETA e dos poços depois da fluoretação, no mês de novembro, em Bauru, 2003 ... 145

TABELA 31 - Classificação das amostras de água da ETA e dos poços, de acordo com o teor de flúor, no mês de novembro de 2003, em Bauru 145

TABELA 32 - Concentração de flúor na água da ETA e dos poços depois da fluoretação, no mês de fevereiro, em Bauru, 2004 ..... 147

TABELA 33 - Classificação das amostras de água da ETA e dos poços, de acordo com o teor de flúor, no mês de fevereiro de 2004, em Bauru 147

TABELA 34 - Concentração de flúor na água da ETA e dos poços, depois da fluoretação, nos meses de maio, agosto e novembro de 2003 e de fevereiro de 2004, em Bauru 149

TABELA 35 - Classificação das amostras de água da ETA e dos poços, de acordo com o teor de flúor, nos meses de maio, agosto e novembro de 2003 e de fevereiro de 2004, em Bauru..... 149

TABELA 36 - Concentração de flúor na água de abastecimento público nos diferentes setores, no mês de maio, em Bauru, 2003

TABELA 36.1 - Concentração de flúor na água de abastecimento público nos diferentes setores, no mês de maio, em Bauru, 2003 154

TABELA 37 - Classificação das amostras de água de acordo com o teor de flúor, dos diferentes setores de abastecimento de Bauru, no mês de maio de 2003 154 
TABELA 38 - Concentração de flúor na água das residências nos diferentes setores de abastecimento público, no mês de agosto, em Bauru, 2003 ............................................. 156

TABELA 38.1 - Concentração de flúor na água das residências nos diferentes setores de abastecimento público, no mês de agosto, em Bauru, 2003 157

TABELA 39 - Classificação das amostras de água de acordo com o teor de flúor, dos diferentes setores de abastecimento de Bauru, no mês de agosto de 2003 157

TABELA 40 - Concentração de flúor na água das residências nos diferentes setores de abastecimento público, no mês de novembro, em Bauru, 2003 ......................................... 159

TABELA 40.1 - Concentração de flúor na água das residências nos diferentes setores de abastecimento público, no mês de novembro, em Bauru, 2003 160

TABELA 41 - Classificação das amostras de água de acordo com o teor de flúor, dos diferentes setores de abastecimento de Bauru, no mês de novembro de 2003 160

TABELA 42 - Concentração de flúor na água das residências nos diferentes setores de abastecimento público, no mês de fevereiro, em Bauru, 2004 ............................................ 162

TABELA 42.1 - Concentração de flúor na água das residências nos diferentes setores de abastecimento público, no mês de fevereiro, em Bauru, 2004 163

TABELA 43 - Classificação das amostras de água de acordo com o teor de flúor, dos diferentes setores de abastecimento de Bauru, no mês de fevereiro de 2004 163

TABELA 44 - Concentração de flúor na água das residências nos diversos setores de abastecimento público, nos meses de maio, agosto e novembro de 2003 e de 2003 e de fevereiro de 2004, em Bauru 165

TABELA 44.1 - Concentração de flúor na água das residências nos diversos setores de abastecimento público, nos meses de maio, agosto e novembro de 2003 e de 2003 e de fevereiro de 2004, em Bauru 166

TABELA 45 - Classificação das amostras de água de acordo com o teor de flúor, dos diferentes setores de abastecimento de Bauru, nos meses maio, agosto e novembro de 2003 e no mês de fevereiro de 2004. 166 
Lista de AbReViaturas, Siglas e Símbolos

\begin{tabular}{|c|c|}
\hline ABENO & Associação Brasileira de Ensino Odontológico \\
\hline ABO & Associação Brasileira de Odontologia \\
\hline ADA & Associação Americana de Odontologia \\
\hline AF & Apatita fluoretada \\
\hline ANVISA & Agência Nacional de Vigilância Sanitária \\
\hline APCD & Associação Paulista de Cirurgiões-Dentistas \\
\hline CDC & Centro de Controle e Prevenção de Doenças \\
\hline ceo-d & $\begin{array}{l}\text { Índice de dentes decíduos cariados, com extração } \\
\text { indicada e obturados }\end{array}$ \\
\hline CFO & Conselho Federal de Odontologia \\
\hline COFINS & Contribuição para Financiamento de Seguridade Social \\
\hline CPO-D & $\begin{array}{l}\text { Índice de Dentes Permanentes Cariados, Perdidos e } \\
\text { Obturados }\end{array}$ \\
\hline CPOS & $\begin{array}{l}\text { Índice de Superfícies Dentárias Cariadas, Perdidas e } \\
\text { Obturadas }\end{array}$ \\
\hline CROSP & Conselho Regional de Odontologia de São Paulo \\
\hline CTCSB & Comitê Técnico Científico de Saúde Bucal \\
\hline DAE & Departamento de Água e Esgoto \\
\hline DCL & Dose Certamente Letal \\
\hline DF & Distrito Federal \\
\hline DTP & Dose Tóxica Provável \\
\hline ERSAs & Escritórios Regionais de Saúde \\
\hline ES & Estado do Espírito Santo, Brasil \\
\hline et al. & E colaboradores \\
\hline
\end{tabular}


ETA

EUA

F

FA

FDI

FINSOCIAL

FNO

FOB

GO

Gr

HA

HF

IADR

IPMET

$\mathrm{Kg}$

L

LTB

mg

MG

MS

Mv

$\mathbf{N}$

$n^{0}$

n

OMS
Estação de Tratamento de Água

Estados Unidos da América

Flúor

Florapatita

Federação Internacional de Odontologia

Substituído por COFINS a partir de 1992

Federação Nacional dos Odontologistas

Faculdade de Odontologia de Bauru

Estado de Goiás, Brasil

Grama

Hidroxiapatita

Ácido Fluorídrico

Associação Internacional de Pesquisas em Odontologia

Instituto de Pesquisas Meteorológicas

Kilograma

Litro

Limite de Tolerância Biológica

Miligrama

Estado de Minas Gerais, Brasil

Ministério da Saúde

Milivoltagem

Número

Número

Número de elementos amostrais

Organização Mundial da Saúde 


\begin{tabular}{|c|c|}
\hline OPAS & Organização Pan-Americana de Saúde \\
\hline PH & Potencial Hidrogênico \\
\hline ppm & Partes por milhão \\
\hline PR & Estado do Paraná, Brasil \\
\hline $\mathbf{R} \$$ & Real (moeda nacional do Brasil em 2004) \\
\hline RS & Estado do Rio Grande do Sul, Brasil \\
\hline $\mathbf{s}$ & Segundos \\
\hline SABESP & $\begin{array}{l}\text { Companhia de Saneamento Básico do Estado de São } \\
\text { Paulo }\end{array}$ \\
\hline sc & Estado de Santa Catarina, Brasil \\
\hline SESP & Fundação Serviços de Saúde Pública \\
\hline SP & Estado de São Paulo, Brasil \\
\hline TF & Thylstrup/Fejerskov \\
\hline TISAB & Total ionic exchange adjustment buffer \\
\hline UNESP & Universidade Estadual Paulista \\
\hline US\$ & $\begin{array}{l}\text { Dólar (moeda nacional dos Estados Unidos da América } \\
\text { em 2004) }\end{array}$ \\
\hline USP & Universidade de São Paulo \\
\hline WHO & Organização Mundial da Saúde \\
\hline${ }^{\circ} \mathrm{C}$ & Graus Celcius \\
\hline$=$ & Igual \\
\hline$<$ & Menor que \\
\hline$\leq$ & Menor ou igual \\
\hline$\mu \mathbf{g}$ & Micrograma \\
\hline ( & Marca Registrado \\
\hline
\end{tabular}




\section{RESUMO}

A importância da fluoretação da água de abastecimento público na prevenção da cárie dentária é reconhecida e exaustivamente estudada desde 1945. O objetivo desta pesquisa foi o de avaliar a concentração de flúor presente na água de abastecimento público de Bauru, SP, antes e depois do processo de fluoretação. Para tanto estabeleceu-se um protocolo para a coleta de amostras de água durante três dias de uma semana, a cada três meses, durante as quatro estações do ano. As amostras foram coletas na ETA e nos 27 poços que abastecem a cidade, antes e depois da fluoretação, e em 63 pontos (residências) estabelecidos a partir do mapa onde estão definidos os 19 setores de abastecimento, com a finalidade de coletar amostras em toda a extensão da rede. A análise das amostras foi realizada em duplicata, utilizando-se o eletrodo íon-sensível (Orion 9609), acoplado ao potenciômetro (Procyon, modelo 720), adicionando $1 \mathrm{~mL}$ de TISAB II a $1 \mathrm{~mL}$ da amostra. A checagem dos resultados da análise das amostras de água foi feita através de nova leitura de $10 \%$ das amostras e com uma reprodutibilidade mínima estabelecida em 90\%. Não foram observadas variações na concentração do flúor naturalmente presente na água em função da sazonalidade de cada uma das estações do ano. A concentração, das 318 amostras analisadas, variou entre 0,05 e 0,15 mg F/L. Entretanto, a média das concentrações de flúor verificadas nas 297 amostras obtidas na ETA e nos poços após a fluoretação variou entre 0,26 e 6,23 mg F/L e das 697 amostras das residências, entre 0,10 e 0,91 mg F/L. A concentração de flúor presente na água de abastecimento público de Bauru, antes da fluoretação, mostrou-se constante, diferente daquela 
verificada após a fluoretação, que apresentou grandes oscilações na sua concentração de flúor, indicando que o sistema de abastecimento de Bauru não mantém constantes os níveis de flúor na água.

Palavras-chave: flúor, fluoretação da água, prevenção, vigilância. 
1 INTRODUÇÃO 


\section{INTRODUÇÃo}

A fluoretação é a adição controlada de um composto de flúor $^{1^{*}}$ à água de abastecimento público com a finalidade de elevar a concentração do mesmo a um teor predeterminado, e desta forma, atuar na prevenção da cárie dentária (BRASIL ${ }^{18}, 1975 ;$ CDC $^{40}, 1995$; BURT; FEJERSKOV $\left.{ }^{30}, 1996\right)$. O flúor pode estar presente naturalmente na água em diferentes concentrações que podem variar de acordo com a sazonalidade da região. Estes valores devem estar definidos antes de se iniciar a fluoretação $\left(\right.$ VIEGAS $^{137}, 1961 ;$ MURRAY $^{93}, 1992 ;$ CALVO $\left.^{36}, 1996\right)$

A fluoretação da água de abastecimento público representa uma das principais e mais importante medidas de saúde pública, podendo ser considerada como o método de prevenção de cárie dentária mais efetivo, quando considerada a abrangência coletiva (KOZLOWSKI; PEREIRA ${ }^{77}$, 2003). Como medida de saúde pública, sua maior vantagem é o fato de alcançar a todos em uma população, que em contrapartida, é também sua maior desvantagem como política social. A fluoretação não permite uma abordagem seletiva para o controle da cárie. Sendo assim, as dúvidas e questionamentos sobre a mesma são freqüentemente uma questão de filosofia social e não científica, uma vez que está apoiada em sua segurança e efetividade comprovadas após cerca de 50 anos de implantação e estudos (BURT; FEJERSKOV ${ }^{30}$, 1996). Há mais de cinco décadas, desde 1945, o flúor tem sido utilizado na prevenção da cárie dentária, resultando em uma

\footnotetext{
${ }^{1 *}$ Termo genérico para definir as formas químicas iônicas (íon flúor ou fluoreto) e inonizável (iônica ou cavalente) do elemento flúor.
} 
melhora significante na saúde bucal das populações (BASTOS; LOPES; FREITAS ${ }^{12}$, 1993; CURY ${ }^{50}, 2001 ;$ LIMA; CURY $\left.^{83}, 2001\right)$. Considerando sua efetividade, custo e freqüência de consumo, a fluoretação das águas de abastecimento tem sido apontada como o melhor método de exposição tópica ao flúor $\left(B_{U R T}{ }^{29}, 1992 ;\right.$ ASSIS et al. ${ }^{5}, 1999 ;$ BUZALAF; CURY; WHITFORD ${ }^{33}, 2001 ;$ CURY $^{50}, 2001$; BUZALAF et al. $\left.{ }^{34}, 2002\right)$.

O Centro de Controle e Prevenção de Doenças (CDC), dos Estados Unidos, admite que o poder preventivo da água fluoretada é de $40 \%$ a 70\%, em crianças, dependendo do índice de prevalência de cárie, reduzindo também a perda de dentes em adultos entre $40 \%$ a $60 \%\left(C D C^{41}\right.$, 1999).

Em outubro de 1975, foi implantada a fluoretação da água de abastecimento público em Bauru. Após 15 anos, em 1990, registrou-se entre os escolares de 12 anos de idade, um importante declínio do índice CPO-D, de 9,89 em 1976 para 3,97 em 1990. Tais valores indicam que se em 1976 os escolares na idade de 12 anos (idade índice recomendada pela Organização Mundial da Saúde), apresentavam em média, 9,89 dentes permanentes atacados pela doença, em 1990, 3,97 dentes permanentes, em média, haviam sido atingidos. A redução constatada é bastante expressiva, cerca 5,92 dentes em média, aproximadamente 60\% de redução. Em 2001, constatou-se a manutenção da tendência de queda, uma vez que o CPO-D médio, para idade de 12 anos foi 1,44. Entre os anos de 1976 e 2001 houve uma redução na prevalência de cárie dentária de cerca de $85 \%$ no município de Bauru (RAMIRES et al. ${ }^{112}$, 2002). Considerando que os efeitos preventivos do flúor, amplamente reconhecidos, em ações de 
saúde pública, são maiores quando a água é empregada como veículo (VIEGAS et al. ${ }^{140}, 1987 ;$ CURY $^{49}, 1992 ;$ MURRAY $^{93}, 1992 ;$ BASTOS; LOPES; FREITAS ${ }^{12}$, 1993; BURT; FEJERSKOV ${ }^{30}$, 1996; BASTING; PEREIRA; MENEGHIM ${ }^{10}$, 1997; NARVAI; CASTELLANOS; FRAZÃO ${ }^{97}$, 2000; BUZALAF et al. $\left.{ }^{34}, 2002\right)$, a fluoretação das águas de abastecimento público em Bauru, vem sendo reconhecida como um importante fator para o declínio da prevalência de cárie dentária (BASTOS; LOPES; FREITAS ${ }^{12}$, 1993; RAMIRES et al. $\left.{ }^{112}, 2002\right)$.

No entanto, vários estudos têm mostrado a dificuldade do Departamento de Água e Esgoto de Bauru em relação à manutenção da concentração de flúor da água de abastecimento público dentro dos teores adequados (NAGEM FILHO ${ }^{94}$, 1997; TAVARES; BASTOS ${ }^{129}$, 1999; BUZALAF $^{35}$, 2002; LODI; RAMIRES; BASTOS $^{85}$, 2003).

Considerando todos os fatores que envolvem o processo de fluoretação da água de abastecimento público, tão importante quanto manter ou adicionar flúor à água, é controlar todo o processo, a fim de que a água se apresente permanentemente com teores adequados de flúor (NARVAI ${ }^{98}$, 2001). Embora seja indispensável que a empresa responsável pela distribuição da água, o Departamento de Água e Esgoto (DAE), controle o processo de tratamento e distribuição, assegurando-Ihe a qualidade exigida pela legislação, isto não é suficiente. São necessárias também, ações no âmbito da vigilância sanitária. Sendo assim, esta pesquisa se propõe avaliar a concentração de flúor na água de abastecimento público de Bauru, antes e depois da fluoretação, durante um ano, para uma análise mais detalhada da fluoretação da água de abastecimento público de Bauru, SP. 
2 REVISÃo dE LITERATURA 


\section{REVISÃo dE LITERATURA}

A revisão de literatura pretende abordar desde a descoberta do flúor presente na água como elemento capaz de interferir nas condições de saúde bucal, sua ação na prevenção da cárie, legislação e métodos que regulamentam o seu uso na água de abastecimento público, até a fluoretação em Bauru, sem ter a pretensão de esgotar o assunto, mas de dar uma ordenação que facilite seu entendimento. 


\subsection{HistóRICO}

As propriedades preventivas do flúor foram descobertas a partir de investigações sobre o seu efeito tóxico no esmalte dentário em desenvolvimento, resultante da sua ingestão. A constatação da fluorose dentária, precedeu a adoção da fluoretação da água de abastecimento público como medida benéfica à saúde bucal. Mediante a observação de tais efeitos e do desejo de investigá-los desencadeou-se uma série estudos, que resultaram na descoberta da fluoretação da água de abastecimento público como medida de prevenção de cárie dentária (THYLSTRUP $\left.{ }^{134}, 1990\right)$. A história da fluoretação pode ser dividida em três períodos: entre 1803-1933; 1933-1945 e a partir de $1945\left(\right.$ BUZALAF $\left.^{35}, 2002\right)$.

EAGER, em 1901, um médico da marinha norte-americana, verificou em Nápoles, na Itália, modificações no esmalte dentário em moradores de uma região geograficamente rica em vulcões, onde a água de consumo apresentava uma alta concentração de húmus vulcânico. A população apresentava afeç̧ões endêmicas que se caracterizavam por manchas escuras no esmalte dentário, descritas como uma alteração dentária conhecida na região como "dente de chiaie". Estas já haviam sido observadas por MORICHINI (Chiaie), também na Itália, em 1803, o que resultou a denominação de "denti de Chiaie" (EAGER ${ }^{55}, 1902$ apud PEREIRA, 2003). No ano de 1888, em Durango, no México, foi descrita a constatação de alterações morfológicas do esmalte dentário $\left(\mathrm{KUHNS}^{78}\right.$, 1888). Por volta de 1911, MCKAY, observou que era relativamente freqüente a ocorrência de um determinado grau de opacidade no esmalte dentário entre os moradores de Colorado Springs, nos Estados Unidos da América. 
Esta alteração dentária era localmente denominada de "Mancha Amarronzada do Colorado". Apesar de ser alta a prevalência da mancha nos dentes dos moradores, verificou-se também que, ocorria apenas entre os nascidos ou aqueles que se mudaram para o local ainda bebês (BURT; FEJERSKOV $\left.{ }^{30}, 1996\right)$.

MCKAY e BLACK, em 1916, não conseguiram estabelecer correlação entre a ocorrência das "Manchas de Colorado" com a idade, sexo ou raça, doenças infecciosas ou fatores socioeconômicos e nutricionais da população local. Entretanto, estabeleceram uma relação direta entre o defeito estrutural do esmalte e a presença de alguma substância na água de abastecimento público. Ao ser constatado que a população residente na área urbana, abastecida pela água de Colorado Springs, desde bebês, ou seja, desde o período de formação dentária, apresentava o manchamento do esmalte e os moradores da área rural, não, estabeleceu-se a relação com a água. Outra constatação importante foi que as crianças desta área apresentavam uma menor prevalência de cárie (MCKAY; BLACK ${ }^{89}, 1916$ apud PEREIRA, 2003; BLACK; MCKAY ${ }^{15}, 1916$ apud FEJERSKOV; EKSTRANT; BURT ${ }^{62}$, 1996). BLACK e MCKAY quando descreveram a ocorrência utilizaram o termo "mottled enamel" (esmalte mosqueado) e associaram tal alteração ao tipo de água consumida. Mais tarde, em 1928, MCKAY sugeriu que a substância presente na água, responsável pelo manchamento dos dentes, também, seria capaz de reduzir a experiência de cárie das crianças (MCKAY ${ }^{90}, 1928$ apud BURT; FEJERSKOV $\left.{ }^{30}, 1996\right)$. Em 1931, PETREY descobriu, acidentalmente, que a água utilizada em Bauxite, uma das cidades americanas em que o esmalte mosqueado tornou-se 
endêmico, possuía 13,7 mg F/L. Assim, foram sendo reunidos os dados sobre a presença de flúor na água e foi se tornando claro que o grau de severidade das manchas dentárias era proporcional à maior quantidade de fluoreto na água, e a afecção do esmalte mosqueado passou a ser chamada de fluorose. Paralelamente a isto, também se percebeu que a fluorose ocorria durante o período de calcificação dos dentes $\left(\mathrm{MCKAY}^{90}, 1928\right.$ apud BURT; FEJERSKOV $\left.{ }^{30}, 1996\right)$.

Com novos métodos de análise espectrográfica, em 1931, foi possível a identificação do flúor presente na água potável das áreas previamente identificadas com ocorrência de fluorose endêmica, uma descoberta que ocorreu praticamente ao mesmo tempo, em três lugares, com as pesquisas de CHURCHILL (1931), SMITH, LANTZ e SMITH (1931), VELU e BALOZET (1931). Com a identificação da causa das alterações no esmalte dentário, registradas até então sem explicação, o Serviço de Saúde Pública dos Estados Unidos designou H. TRENDLEY DEAN para estudar o problema (BURT; FEJERSKOV $\left.{ }^{30}, 1996\right)$.

Na Segunda etapa da história da fluoretação (1933-1945), DEAN, através de vários estudos epidemiológicos, estabeleceu inicialmente um índice de fluorose em uma escala ordinal de sete pontos, baseado no grau de severidade, que posteriormente foi por ele mesmo modificado para uma escala de seis pontos pela combinação das categorias de moderadamente severa e severa. Confirmou a hipótese proposta por MCKAY, de que a concentração de flúor na água que provocava o manchamento dos dentes, seria também responsável por uma ação preventiva na redução da cárie dentária. Até meados dos anos 30, foram realizados estudos com extensas 
análises de água, quando foi encontrada fluorose leve ou muito leve em cerca de $12 \%$ das populações abastecidas de água com concentração de flúor de 1,0 mg F/L. Em 1933, MCKAY observou que os habitantes de Colorado Springs apresentavam os dentes manchados, porém com alta resistência à cárie, apesar de apresentarem o esmalte dentário hipoplásico (BURT; FEJERSKOV $\left.{ }^{30}, 1996\right)$.

Considerado como o estudo epidemiológico de maior relevância realizado por DEAN e um marco na epidemiologia, a partir de 1942, desenvolveu-se o "Estudo das 21 Cidades", que procurou estabelecer a concentração de flúor na água que provocava o manchamento dentário, ao mesmo tempo em que se buscou descobrir as concentrações capazes de uma ação preventiva e eficaz na redução da cárie dentária. Para tanto, foi analisada a experiência de cárie em crianças de 12 a 14 anos de idade, nascidas e residentes em 21 cidades de quatro estados com diferentes concentrações de flúor na água de abastecimento, variando de 0,1 a 2,5 mg/L. Os resultados mostraram que numa concentração de 0,6 mg F/L a redução na experiência de cárie dentária era de 50\%, quando comparados com os observados onde a concentração de flúor na água era de 0,2 mg/L. Verificou-se ainda uma redução de 60\% em concentrações de 1,2 mg F/L, e uma redução ainda maior em locais com 1,8 mg F/L. No entanto, era acompanhada por um nível inaceitável de fluorose, reforçando a tese da possibilidade do controle da cárie por meio da fluoretação controlada, com níveis adequados de flúor na água de abastecimento (BURT; FEJERSKOV ${ }^{30}, 1996$; KOZLOWSKI; PEREIRA ${ }^{77}$, 2003). 
Ainda em 1942, concluiu-se que havia uma importante correlação diretamente proporcional entre prevalência de fluorose dentária e concentração de íon flúor na água de consumo e, também, uma importante correlação e, esta inversamente proporcional, entre a presença de íon flúor e a prevalência de cárie dentária. Desde então ficou estabelecido que o flúor presente na água de abastecimento público em uma concentração em torno de $1 \mathrm{mg} / \mathrm{L}$, promoveria a máxima redução no índice CPO-D, e que quando o teor excedia 1,5 mg/L, não havia melhora significativa no índice e, no entanto, predispunha a um aumento na ocorrência e severidade de fluorose dentária (BURT; FEJERSKOV ${ }^{30}$, 1996; KOZLOWSKI; PEREIRA ${ }^{77}$, 2003).

A terceira etapa da história da fluoretação tem seu início por volta de 1945, a partir dos resultados obtidos com os estudos de DEAN e com os primeiros estudos experimentais a respeito da fluoretação da água de abastecimento com concentrações em torno de $1 \mathrm{mg}$ F/L. O objetivo era o de testar a hipótese de que a adição controlada de flúor à água de abastecimento público, naturalmente com baixas concentrações, reduziria a experiência de cárie da população (BURT; FEJERSKOV ${ }^{30}$, 1996; KOZLOWSKI; PEREIRA $\left.{ }^{77}, 2003\right)$.

Grand Rapids, no Estado de Michigan, em 25 de janeiro de 1945, tornou-se a primeira cidade do mundo a ajustar o teor de flúor da água de abastecimento para $1 \mathrm{mg} / \mathrm{L}$, tendo como controle negativo a cidade de Muskegon (Michigan) onde a concentração era de 0,1mg F/L e controle positivo, Aurora (Illinois), onde a concentração de flúor natural na água era de 1,2 mg/L. Em maio do mesmo ano, no Estado de Nova York, a cidade de Newburgh tem sua água fluoretada na concentração de $1 \mathrm{mg} \mathrm{F/L}$, onde o 
controle negativo, foi a cidade de Kingston, do mesmo estado e com concentração de 0,1 mg F/L. Em junho, de 1946, Brandford, no Canadá, fluoreta sua água com 1,2 mg F/L, tendo Sarnia como controle negativo, com 0,1 mg F/L e, Stratford, onde a concentração de flúor natural na água era 1,3 mg F/L, como controle positivo, ambas no Canadá (BURT; FEJERSKOV ${ }^{30}$, 1996; KOZLOWSKI; PEREIRA ${ }^{77}$, 2003).

TABELA 1 - Após 5 anos de fluoretação, com o levantamento epidemiológico realizado em diferentes datas, o índice CPO-D médio de crianças de 5 a 16 anos de idade, em Grand Rapids, Aurora e Muskegon

\begin{tabular}{cccccc}
\hline & \multicolumn{2}{c}{ GRAND RAPIDS } & AURORA & \multicolumn{2}{c}{ MUSKEGON } \\
\hline Idade & $\mathbf{1 9 4 5}$ & $\mathbf{1 9 5 0}$ & $\mathbf{1 9 4 6}$ & $\mathbf{1 9 4 5}$ & $\mathbf{1 9 5 0}$ \\
\hline 5 & 0,11 & 0,03 & 0,06 & 0,06 & 0,14 \\
8 & 2,94 & 2,16 & 1,04 & 2,81 & 2,58 \\
10 & 4,92 & 3,56 & 2,02 & 4,91 & 4,44 \\
12 & 8,07 & 7,02 & 2,95 & 8,66 & 7,21 \\
15 & 12,48 & 11,80 & 4,54 & 12,86 & 10,32 \\
16 & 13,50 & 11,83 & 5,19 & 14,07 & 12,51 \\
\hline Fonte: Dean, H.T. et al., 1950 apud Bastos; Lopes; Ramires ${ }^{14}, 2001$.
\end{tabular}

Com os resultados (TABELA 1) foi possível concluir que não havia diferença entre a ingestão de água natural ou artificialmente fluoretada. No entanto, as conclusões que indicavam a concentração ideal de flúor em torno de $1 \mathrm{mg} / \mathrm{L}$ tinham como referência áreas geográficas definidas, aparentemente não considerando que a concentração ideal de flúor poderia variar de acordo com as diferenças climáticas (KOZLOWSKI; PEREIRA ${ }^{77}$, 2003). Posteriormente, esta variável foi estudada por HODGE (1950), GALAGAN e LAMSON (1953) e por GALAGAN e VERMILLION (1957), que associaram a quantidade de flúor ingerido à temperatura média anual de 
uma determinada região, uma vez que quanto maior a temperatura maior seria a quantidade de água ingerida e, conseqüentemente, maior a quantidade de flúor (GALAGAN; VERMILLION ${ }^{71}, 1957$ ). Desta forma, para que se alcançasse o objetivo de oferecer a prevenção da cárie sem o aumento na incidência de fluorose, passou-se a recomendar que as concentrações consideradas ótimas de flúor, presente na água de abastecimento público, deveriam variar entre 0,7 e 1,2 mg F/L, de acordo com a temperatura local (BURT; FEJERSKOV ${ }^{30}$, 1996; KOZLOWSKI; PEREIRA $^{77}$, 2003). A temperatura é o fator ambiental de maior importância a ser considerado para a determinação da concentração de flúor na água, pois o consumo de água está diretamente relacionado à temperatura. Sendo assim, em países tropicais, a concentração ideal recomendada é de 0,7 mg F/L (ANGMAR-MANSSON; WHITFORD ${ }^{2}, \quad$ 1990; FEJERSKOV; THYLSTRUP ${ }^{61}, 1994$; ASSIS et al. $\left.{ }^{5}, 1999\right)$.

A Organização Mundial da Saúde, em 1958, reconheceu a importância da fluoretação e instituiu um Comitê de Peritos em fluoretação da água, que em seu primeiro relatório deu parecer favorável à fluoretação indicando-a como uma medida de saúde pública. O mesmo Comitê sugeriu que pesquisas de outros métodos e veículos de aplicação tópica de flúor fossem desenvolvidas, a fim de permitir o uso do composto em locais onde a fluoretação não pudesse ser implantada. Durante a 22a Assembléia Mundial de Saúde, em 1966, a mesma recomendação foi feita aos Estados Membros (VIEGAS et al. $\left.{ }^{140}, 1987\right)$.

Assim, em 1962, o Serviço de Saúde Pública dos EUA estabeleceu limites para a adição de flúor nas diversas zonas climáticas da 
América do Norte, que foram consideradas determinantes para graduar as concentrações em função da temperatura média anual $\left(18^{\circ} \mathrm{C}=1,2 \mathrm{mg} \mathrm{F} / \mathrm{L}\right.$; $19-26^{\circ} \mathrm{C}=0,9 \mathrm{mg} \mathrm{F} / \mathrm{L} ; 27^{\circ} \mathrm{C}$ ou mais=0,7 mg F/L). Estes limites também foram adotados na América Central e do Sul como base para determinar as concentrações de flúor na água. A concentração ótima de flúor na água de abastecimento deve possuir um nível que ofereça o mínimo de risco de fluorose dentária e melhore significativamente a prevenção contra a cárie, ou seja, proporcionar o maior benefício com o menor risco (MURRAY $\left.{ }^{93}, 1992\right)$.

O Public Health Service Drinking Water Standards dos Estados Unidos recomenda níveis ótimos de flúor de 0,$7 ; 0,8 ; 0,9 ; 1,0 ; 1,1$ e 1,2 mg F/L para temperaturas médias anuais, em ${ }^{\circ} \mathrm{C}$, de 26,3 a 32,$5 ; 21,5$ a 26,2; 17,8 a 21,$4 ; 14,7$ a 17,$7 ; 12,2$ a 14,6 ; e 10,0 a 12,1 ; respectivamente (MURRAY $\left.{ }^{93}, 1992\right)$.

Foi então desenvolvido na Organização Mundial da Saúde, um programa para a promoção da fluoretação de água de abastecimento de comunidades, apresentado na 25ª Assembléia Mundial de Saúde, em 1975. Ressaltando que o problema da cárie dentária não seria resolvido por meio de procedimentos curativos, a Assembléia aprovou o programa e, ainda, enfatizou a importância de se utilizar o flúor nas concentrações adequadas na água de abastecimento. O programa obteve aprovação por unanimidade dos 148 países-membros, incluindo os países que adotam outros métodos sistêmicos (Suécia, Holanda, Áustria, Bélgica, Dinamarca, Itália, Suíça e outros) (VIEGAS et al. $\left.{ }^{140}, 1987\right)$.

A Federação Dentária Internacional (FDI), Fundação Kellogg (FK) e a Organização Mundial da Saúde (OMS), realizaram em1982, a 
Conferência sobre Fluoretos, onde seus participantes concluíram que a fluoretação da água de abastecimento público é uma medida ideal de saúde pública para a prevenção da cárie dentária em países onde existem serviços de tratamento de água. Considerando que a fluoretação é cientificamente comprovada uma medida preventiva, eficiente e segura, reafirmou-se que esta medida além de implantada deve ser mantida (VIEGAS et al. ${ }^{140}, 1987$ ). 


\subsection{Metabolismo do Flúor}

A água de abastecimento público, a água engarrafada, os dentifrícios, os produtos odontológicos fluoretados, além dos alimentos e bebidas produzidos com água fluoretada, são considerados como importantes fontes de ingestão de flúor para indivíduos acima de 1 ano de idade, sendo que a água de abastecimento e os dentifrícios são as de maior impacto. (BURT ${ }^{29}$, 1992; WHITFORD ${ }^{146}$, 1994; SILVA; REYNOLDS ${ }^{123}$, 1996; EKSTRAND; OLIVEBY ${ }^{57}$, 1999; FOMON; EKSTRAND; ZIEGLER ${ }^{64}$, 2000; BASTOS et al. ${ }^{13}$, 2001; LIMA; CURY ${ }^{83}, 2001$; RAMIRES et al. ${ }^{113}$, 2004). Portanto, ao se considerar alimentos industrializados, a água fluoretada tem um impacto maior na prevalência de fluorose, indiretamente, quando é usada no processamento de leites e outros alimentos, além das bebidas (BURT $^{29}$, 1992; DIAS; ROSA; BUZALAF, 2000). A quantidade de ingestão diária de flúor, normalmente aceita como ideal para a prevenção da cárie e segura para a de fluorose, é de 0,05 a 0,07 mg de F/Kg da massa corporal (BURT $^{29}$, 1992; BUZALAF; CURY; WHITIFORD ${ }^{33}$, 2001). As concentrações de flúor presentes nas bebidas, onde se incluem sucos de frutas, chás, refrigerantes, entre outros, são decorrentes daquelas encontradas na água usada para o seu preparo. Estas concentrações, normalmente variam entre 0,1 a 1,4 mg/L, exceto para os chás, que podem chegar a $7 \mathrm{mg} \mathrm{F/L}$ (CURY $^{48}$, 1981; CLOVIS; HARGREAVES ${ }^{44}$, 1988; PANG; PHILIPPS; BAWDEN $^{107}$, 1992). No entanto, em alguns alimentos industrializados, comumente consumidos por crianças brasileiras, e, produzidos em diferentes regiões, com água fluoretada ou não, foram constatadas concentrações elevadas de flúor. Foram analisados três lotes dos cereais 
Mucilon $^{\circledR}$ e Neston $^{\circledR}$ e de um achocolatado líquido, o Toddynho ${ }^{\circledR}$, entre outros alimentos. Mas, especificamente, estes três alimentos apresentaram uma concentração de flúor de 2,43 $\mu \mathrm{g} / \mathrm{g}, \quad 6,16 \mu \mathrm{g} / \mathrm{g}$ e $1,18 \mathrm{mg} / \mathrm{L}$, respectivamente. Considerando que a ingestão "ótima de flúor" é em torno de 0,05 a $0,07 \mathrm{mg} / \mathrm{kg}$ peso corporal/dia, estes alimentos podem ser considerados como importantes fatores de risco para fluorose dentária, especialmente quando associados a outras fontes de ingestão de flúor. Tomando como exemplo, uma criança de 2 anos de idade, pesando aproximadamente $12 \mathrm{~kg}, 36 \%$ do limite máximo de sua ingestão diária recomendada (0,07 $\mathrm{mg} \mathrm{F} / \mathrm{kg}$ peso corporal), seria alcançado quando estes alimentos são consumidos apenas uma vez ao dia (BUZALAF ${ }^{35}$, 2002). Dados recentes mostram a ocorrência de fluorose dentária com ingestão de flúor de menos de 0,04 mg/kg peso corporal/dia (BAELUM et al. ${ }^{6}, 1987$; FEJERSKOV; BAELUM; RICHARDS ${ }^{62}$, 1996). Vários estudos têm sido realizados com a finalidade de estimar a ingestão diária de flúor por crianças (WHITFORD $^{144}$, 1987; BURT ${ }^{29}$, 1992; LEVY; KIRITSY; WARREN ${ }^{80}, 1995$; FEJERSKOV, BAELUM; RICHARDS ${ }^{62}$, 1996; GUHA-CHOWDHURY; DRUMMOND; SMILIE ${ }^{72}$, 1996; RICHARDS; BANTING, 1996; LEVY; GUHACHOWDHURY $^{81}$, 1999; BUZALAF ${ }^{35}, 2002$; PESSAN et al. $\left.{ }^{109}, 2003\right)$. Entretanto, o nível "ótimo" de ingestão sistêmica de flúor adequado para o controle da cárie dentária, sem o risco de desencadear lesões de fluorose clinicamente inaceitáveis, ainda não é precisamente conhecido (GUHACHOWDHURY; DRUMMOND; SMILLIE ${ }^{72}$, 1996; BUZALAF $^{35}$, 2002).

Vários aspectos do metabolismo do flúor são dependentes do pH do meio e da migração transmembrana do íon flúor que ocorre na forma de 
HF. Por isso, grande parte das características fisiológicas do flúor podem ser explicadas pela difusibilidade do HF. A absorção no estômago está diretamente relacionada à acidez do mesmo, ao conteúdo e à rapidez do esvaziamento gástrico para o intestino delgado. Portanto, quanto mais baixo for o $\mathrm{pH}$, maior e mais rápida será a absorção, e o pico de concentração de flúor nos fluidos corporais vai se dar em menos tempo (WHITFORD ${ }^{146}, 1994$; WHITFORD ${ }^{147}, 1994 ;$ WHITFORD $\left.^{148}, 1996\right)$.

Além do $\mathrm{pH}$, a quantidade e a composição dos alimentos presentes no estômago no momento da ingestão de alguma fonte de flúor, têm grande influência na absorção do flúor. Sendo assim, se no estômago estiverem alimentos aos quais o flúor possa se complexar ou já esteja complexado, parte do íon será excretado nas fezes. A presença de cálcio e outros cátions bi e trivalentes pode desencadear uma ligação química, formando compostos insolúveis, pobremente absorvíveis. Por isso, a dieta rica em cálcio e magnésio está associada a uma baixa absorção de flúor. No entanto, se no momento da ingestão o estômago estiver vazio, a absorção poderá ser total (FEJERSKOV; THYSLTRUP ${ }^{61}, 1994$; ASSIS et al. ${ }^{5}, 1999$ ).

Quando passa pelo estômago sem ser absorvido, o flúor vai seguir para o intestino delgado, que tem uma grande capacidade de absorção. No intestino delgado proximal a absorção ocorre com facilidade, uma vez que não depende de $\mathrm{pH}$ e se dá predominantemente na forma de íon flúor (difusão). Estima-se que após 2 horas, este seja responsável por cerca de $80 \%$ da absorção total do flúor (WHITFORD ${ }^{145}$, 1990; MESSER; OPHAUG ${ }^{91}, 1993 ;$ WHITFORD $\left.^{146}, 1994\right)$. 
Uma vez absorvido, o flúor é rapidamente distribuído pelo corpo. Os níveis plasmáticos geralmente começam a apresentar sinais de aumento 10 minutos após a ingestão, atingindo o pico máximo entre 20 a 60 minutos, e então, retornam para os níveis de pré-ingestão depois de 3 a 11 horas, dependendo da dose (WHITFORD $\left.{ }^{148}, 1996\right)$. Aproximadamente 99\% do flúor retido no organismo está associado aos tecidos mineralizados, principalmente ao osso, mas também, ao esmalte e à dentina. A concentração de flúor de todo o esmalte reflete o nível de exposição durante o período de formação dos dentes, enquanto que as concentrações presentes na dentina e no osso são geralmente proporcionais à ingestão ao longo do tempo. O aumento da retenção de flúor pelo esqueleto em desenvolvimento parece ser devido quase que inteiramente ao rico suprimento sangüíneo e maior área de superfície dos cristalitos ósseos, que são menores, mais desorganizados e mais numerosos, quando comparados com o osso maduro (WHITFORD; PASHILEY; REYNOLDS ${ }^{143}, 1979$; WHITFORD ${ }^{147}$, 1994). Com relação ao efeito cumulativo do flúor nos ossos, em decorrência da sua incorporação em função do tempo de exposição, é preciso considerar o Limite de Tolerância Biológica (LTB) ao flúor. Este limite avalia a excreção urinária, que normalmente é 4 vezes menor que o limite máximo de 3 mg/L, em condições de normalidade (CURY ${ }^{49}, 1992$; BUENDIA $^{27}, 1996$; BUENDIA $\left.{ }^{28}, 1997\right)$.

Depois que aproximadamente $50 \%$ de uma dose de flúor ingerida foi absorvida, as concentrações plasmáticas caem rapidamente, o que se deve à excreção renal e à incorporação aos tecidos mineralizados. Pelo fato dos rins serem a maior via de excreção do flúor, os fatores que alteram o pH 
urinário podem afetar sobremaneira o metabolismo do flúor. Estes fatores incluem a composição da dieta, determinadas doenças respiratórias ou metabólicas, algumas drogas e a altitude de residência. Em torno de 50\% do flúor absorvido diariamente pelo trato gastro-intestinal de adultos, é excretado pela urina (WHITFORD $\left.{ }^{145}, 1990\right)$. O flúor encontrado nas fezes, normalmente corresponde àquele que não foi absorvido. O flúor também pode ser excretado através do suor (WHITFORD $\left.{ }^{146}, 1994\right)$. 


\subsection{MECANISMO de AçÃo do FLÚOR}

O flúor é o elemento mais eletronegativo do grupo dos halógenos, tendo assim, uma grande capacidade de reagir com outros elementos químicos, formando compostos orgânicos e inorgânicos. Vários aspectos diferem o flúor dos demais elementos do grupo, incluindo o fato de se combinar reversivelmente com íons de hidrogenio para formar um ácido fraco, o HF; de ser um potente inibidor de várias enzimas; de ter uma velocidade de eliminação dos organismos muitas vezes mais rápida que a dos demais halógenos; afinidade por tecidos calcificados; capacidade de estimular a formação de tecido ósseo e, ainda, a sua grande capacidade de inibir e também de reverter o processo de formação de lesão de cárie. Grande parte das propriedades do flúor podem ser explicadas com base na capacidade de difusão do HF (FEATHESTONE et al. ${ }^{58}$, 1990; FEATHESTONE ${ }^{59}$, 1999; BUZALAF $\left.{ }^{35}, 2002\right)$.

O esmalte e a dentina são compostos minerais à base de apatita (sais contendo cálcio e fosfato), extremamente dinâmicos tanto no período de desenvolvimento dentário, quanto após a sua erupção $\left(C U R Y^{50}, 2001\right)$. Este fato justifica que durante muito tempo permaneceu a teoria de que as propriedades cariostáticas do flúor fossem decorrentes da sua incorporação ao esmalte. Acreditava-se que através do uso sistêmico do flúor ocorreria uma melhora na estrutura cristalina dos dentes, tornando-os mais resistentes à cárie, uma vez que incorporado ao dente formaria fluorapatita (FA). Esta, sendo menos solúvel que a hidroxiapatita (HA), não só explicaria a menor ocorrência de cárie quando da ingestão de água fluoretada, como também, justificaria o uso de flúor sistêmico (suplementos) (CURY ${ }^{50}, 2001$; 
BUZALAF ${ }^{35}$, 2002). No entanto, alguns estudos demonstraram que quando se ingere flúor durante a formação dos dentes, não ocorre a formação FA, mas sim desencadeia a incorporação de uma quantidade de flúor correspondente a cerca de apenas $10 \%$ de substituição de HA por FA. Esta concentração de flúor não torna o esmalte mais resistente aos ácidos produzidos pelas bactérias. Para aumentar a resistência do esmalte seriam necessários 30.000 ppm F (OGAARD et al. ${ }^{101}$, 1988, OGAARD et al. ${ }^{102}$, 1991; TEN CATE ${ }^{131}, 1997$; FESTHERSTONE, 1999; LIMEBACK $\left.{ }^{84}, 1999\right)$. O flúor incorporado na estrutura do esmalte tem um efeito inexpressivo ou mesmo inesistente (LIMEBACK ${ }^{84}$, 1999; FEATHERSTONE $\left.{ }^{57}, 1999\right)$.

Considerando que no esmalte daquele que ingere flúor não se forma FA, mas sim, apatita fluoretada (AF), a ingestão de flúor como medida indispensável para o controle da cárie deveria ser repensada (CURY ${ }^{50}$, 2001). No entanto, a exposição ao flúor tanto pela ingestão de água fluoretada e/ou pelo uso de dentifrícios fluoretados, propicia a presença constante de flúor na saliva, mudando suas propriedades físico-químicas com relação ao chamado pH crítico de dissolução do dente. A saliva por apresentar cálcio e fosfato, principais minerais componentes da estrutura cristalina dos dentes, protege naturalmente tanto o esmalte quanto a dentina. Essa propriedade biológica da saliva é pH-dependente e, assim, variações de pH decorrentes da ingestão de alimentos ou da conversão de açúcar em ácido pela placa dentária, estabelecerão o limite de capacidade da saliva de proteger os dentes, que é aumentada na presença de flúor (CURY $^{50}, 2001 ;$ BUZALAF $^{35}, 2002 ;$ WHITFORD $\left.^{149}, 2002\right)$. 
A partir de 1990, com os resultados de alguns estudos, tornou-se consenso na literatura de que manter um suprimento constante de baixos teores de flúor na cavidade bucal, particularmente na interface placa/saliva/esmalte, é o meio mais efetivo de prevenção de cárie dentária. Sendo assim, pode-se afirmar que a atividade dos íons flúor no fluído da cavidade bucal é mais importante que a alta concentração de flúor no esmalte, uma vez que, potencializa a resposta de menor solubilidade do esmalte frente às atividades bacterianas (FEJERSKOV; THYLSTRUP;

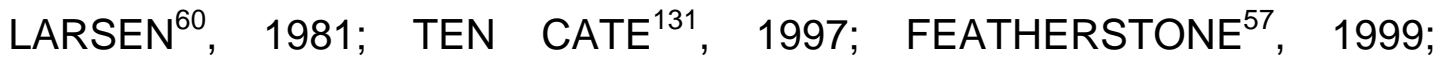
FUKUSHIMA et al. ${ }^{70}, 2000 ;$ WHITFORD $\left.{ }^{149}, 2002\right)$.

Para melhor entender o processo de remineralização é importante saber como ocorre a desmineralização, que desencadeia a remineralização. O conteúdo mineral do esmalte dentário é constituído por cristais de hidroxiapatita, que se acham distribuídos de modo a formar os prismas de esmalte. Entre os prismas, existem as lacunas denominadas de espaços interprismáticos, por onde circula o fluido do esmalte. Esta disposição dos prismas faz com que se formem verdadeiras vias de circulação deste fluido, estabelecendo-se assim uma pressão de difusão do esmalte para a saliva e vice-versa. Sempre que houver uma produção de ácidos, em especial do ácido lático, resultante do metabolismo bacteriano, ocorrerá a saída de íons cálcio e fosfato dos cristais de hidroxiapatita. Desta forma, tem-se um aumento das concentrações de cálcio e fosfato no fluido do esmalte que se difunde para a saliva. Assim ocorre a desmineralização. Quando termina o desafio ácido cariogênico, no momento em que a concentração de cálcio e fosfato na saliva for maior que a do fluido do esmalte, o fluxo de íons ocorre 
no sentido contrário, da saliva para o esmalte $\left(B U_{Z A L A F}^{32}, 1996\right.$; ASSIS et al. $^{5}, 1999 ;$ WHITFORD $\left.{ }^{149}, 2002\right)$.

A medida em que a saliva flui na placa dentária, seus componentes tampão (bicarbonato, fosfato e peptídeos) neutralizam os ácidos produzidos pelas bactérias e o pH retorna à normalidade, ao menos enquanto o fluxo salivar é normal. Este fenômeno diminui e/ou paralisa a dissolução do mineral subsuperficial. A presença de flúor, além de proteção frente à dissolução, promove uma aceleração no processo de remineralização, ou seja, na superfície dos cristais parcialmente dissolvida no interior da lesão, uma nova superfície é formada sobre os cristais (FEATHERSTONE, 1999; BUZALAF ${ }^{35}$, 2002).

Vários estudos demostraram que o flúor em contato com os cristais de apatita é muito mais efetivo para inibir a desmineralização, à medida em que a solução onde está presente, circunda os cristais e o flúor se adsorve fortemente à superfície dos cristais de apatita carbonatada (mineral de esmalte), atuando como um potente mecanismo de proteção contra a dissolução ácida da superfície do cristal. Sendo assim, se o flúor está presente no fluido da placa no exato momento em que as bactérias produzem o ácido, este vai penetrar com o ácido na subsuperfície do dente, adsorver-se à superfície dos cristais e protegê-los da dissolução (FEATHERSTONE et al. ${ }^{56}$, 1990; TEN CATE; FEATHERSTONE ${ }^{130}$, 1991; WHITFORD ${ }^{149}$, 2002). A presença de flúor pode aumentar a velocidade da remineralização, pois este age no processo quando se adsorve à superfície e atrai íons de cálcio. A saliva é supersaturada em relação ao cálcio e fosfato, dirigindo a força no sentido de levar os minerais de volta ao dente. 
Quando o flúor presente atrai os íons de cálcio, forma uma nova superfície, que vai captar preferencialmente, flúor da solução que circunda os cristais e excluir carbonato. Como conseqüência deste processo forma-se a flúorhidroxiapatita (TEN CATE; FEATHERSTONE ${ }^{130}$, 1991; WHITFORD ${ }^{149}$, 2002). Na presença de baixas concentrações de flúor, a hidroxiapatita se dissolve abaixo do seu $\mathrm{pH}$ crítico, mas os íons minerais podem se repreciptar como fluorapatita ou flúor-hidroxiapatita. Este mecanismo não só previne a perda de minerais, como também aumenta a resistência superficial dos cristais neoformados, cuja superfície passará a se comportar como fluorapatita, que é mais resistente à desmineralização (FEATHERSTONE, 199957; WHITFORD ${ }^{149}, 2002 ;$ BUZALAF $\left.^{35}, 2002\right)$. Quanto à inibição das bactérias, não existem dúvidas com relação aos efeitos do flúor, mas para que estes ocorram é necessário que a concentração de flúor exceda em muito aquela que prevalece na cavidade bucal (TEN CATE ${ }^{132}$, 1999). Portanto, do ponto de vista de ação do flúor na prevenção da cárie dentária, os efeitos nos processos de desmineralização e remineralização são notadamente os mais importantes (BRUNELLE; CARLOS ${ }^{26}$, 1990; HOROWITZ ${ }^{73}, \quad 1990 ; \quad$ THYLSTRUP $^{134}, \quad 1990 ; \quad$ TEN CATE $^{132}, \quad 1999$; WHITFORD $\left.{ }^{149}, 2002\right)$.

Alguns estudos demonstraram uma redução de cárie inferior a $50 \%$ quando o consumo de água fluoretada é adotado depois dos 4 anos de idade. Nem todas as superfícies dos dentes se beneficiam igualmente da ação do flúor. As faces proximais e as outras superfícies lisas são muito mais protegidas que as depressões e sulcos (BRUNELLE; CARLOS ${ }^{26}$, 1990; THYLSTRUP ${ }^{134}, 1990 ;$ MURRAY $\left.^{93}, 1992\right)$. 
A fluoretação da água de abastecimento público é reconhecida como sendo um dos meios mais efetivos para se manter constante a presença do flúor na cavidade bucal $\left(\mathrm{CURY}^{50}, 2001\right.$; BUZALF, 2002; WASDIN; SCHAFER; ADAIR, 2002). Quando é interrompida a ingestão de flúor, o organismo não dispõe de mecanismos para manter constante sua presença. Portanto, quando ocorre a interrupção ou paralisação da fluoretação da água de abastecimento público, a concentração de flúor na saliva, não se mantém constante (HOROWITZ ${ }^{73}, 1990 ;$ CURY $\left.^{50}, 2001\right)$. 


\subsection{TOXICOLOGIA DO FLÚOR}

Os resultados positivos obtidos mediante o uso do flúor, na prevenção da cárie dentária, são indiscutíveis e reconhecidos cientificamente. No entanto, a ingestão excessiva deste composto no período de formação dos dentes pode levar à fluorose dentária. A partir da década de 80 ocorreu um declínio na prevalência e incidência de cárie e, simultâneamente, um aumento na prevalência de fluorose dentária. Embora haja consenso da relação existente entre o uso do flúor e a redução de cárie dentária, portanto, o reconhecimento da sua ação terapêutica, é preciso entender que o flúor é uma substância tóxica e, como tal, pode causar efeitos colaterais quando altas doses são ingeridas agudamente, ou mesmo, baixas doses cronicamente. Estes efeitos podem desencadear desde distúrbios gástricos reversíveis e redução temporária da capacidade urinária, fluorose dentária ou esquelética e, eventualmente, até mesmo a morte, uma vez que, estão diretamente relacionados à dose, tempo de ingestão e idade (THYLSTRUP; FEJERSKOV ${ }^{133}$, 1978; FEJERSKOV; THYLSTRUP; LARSEN $^{60}, 1981 ;$ BURT $^{29}, 1992 ;$ WHITFORD $^{148}$, 1996; BUZALAF; CURY; WHITFORD $\left.{ }^{33}, 2001\right)$.

O flúor se distribui rapidamente pelo organismo após a sua ingestão. Uma vez que os níveis plasmáticos geralmente começam apresentar sinais de aumento 10 minutos após a ingestão, o pico máximo é atingido entre 20 a 60 minutos, e então, retornam para os níveis de préingestão depois de 3 a 11 horas, dependendo da dose (WHITFORD ${ }^{148}$, 1996). Haja vista que o gradiente de $\mathrm{pH}$ entre os meios intra e extracelulares pode ser aumentado ou diminuído pela alteração do pH 
extracelular, é possível promover a entrada ou saída de flúor nas células. Esta é a base para a sugestão de que a alcalinização dos fluidos corporais seja um bom coadjuvante no tratamento de toxidade aguda pelo flúor (WHITFORD; REYNOLDS; PASHELY $\left.{ }^{143}, 1979\right)$.

Com relação à intoxicação aguda pelo flúor a dose seguramente tolerada, também denominada "dose tóxica provável" (DTP) tem sido definida como sendo a dose mínima capaz de provocar sinais e sintomas de intoxicação, incluindo a morte, e que necessite intervenção terapêutica e/ou hospitalar. A DTP é de aproximadamente $5 \mathrm{mg} \mathrm{F/kg} \mathrm{de} \mathrm{peso} \mathrm{corporal.} \mathrm{A}$ dose certamente letal (DCL), está entre 32 e 64 mg F/kg peso corporal, embora haja casos de morte com doses menores (VIEGAS et al. ${ }^{140}$, 1987; WHITFORD ${ }^{148}, 1996 ;$ BUZALAF $\left.^{35}, 2002\right)$.

Os efeitos tóxicos do flúor sobre o esmalte dentário em desenvolvimento são do tipo crônico, e estão associados com sua capacidade de atuação tanto sobre os ameloblastos como sobre o estágio de maturação da formação do esmalte (THYLSTRUP; FEJERSKOV ${ }^{133}$, 1978; BURT ${ }^{29}$, 1992; LEWIS; BANTING ${ }^{82}$, 1994; HOROWITZ ${ }^{74}, 1996 ;$ ASSIS et al. $\left.{ }^{5}, 1999 ;\right)$. Tratando-se de um distúrbio sistêmico, que ocorre durante o desenvolvimento do dente, sempre há simetria no grau de fluorose entre os dentes homólogos afetados. Nem todos os dentes são acometidos por fluorose dentária, e o grau de fluorose é diferente de um grupo de dentes para outro. Esta constatação ressalta a importância da idade da população examinada, garantindo a verificação do real índice de ocorrência de fluorose. O esmalte normal é formado por cristais de hidroxiapatita arranjados em um alto padrão de organização, formando os prismas de esmalte. Os cristais 
estão unidos de tal forma que os espaços entre eles são muitos pequenos, conferindo a aparência de translucidez ao esmalte. A superfície do esmalte normal é lisa e brilhante, geralmente de cor branca pálida cremosa. A fluorose altera as características da camada externa do esmalte. Os primeiros sinais que podem ser vistos como linhas brancas e finas cruzando toda a superfície do esmalte, que em casos de maior gravidade podem chegar à perda da principal parte do esmalte externo, resultando em uma mudança na forma anatômica da superfície do dente. Um halo cervical de esmalte opaco é geralmente notado (BAELUM ${ }^{6}, 1987$; FEJERSKOV; THYLSTRUP $\left.{ }^{61}, 1994\right)$.

A ocorrência e a gravidade da fluorose dentária podem variar entre os diferentes indivíduos e populações, devido à influência de fatores ambientais e fisiológicos, bem como à maior exposição e disponibilidade a diferentes fontes de ingestão de flúor. Estes fatores, mesmo em comunidades onde a água de abastecimento público não é fluoretada, podem resultar em concentrações aumentadas de flúor nos fluídos corporais e alterações nas manifestações aos efeitos tóxicos do flúor em tecido mineralizados com respostas individuais. Entretanto, há uma relação direta entre o aumento da quantidade de flúor ingerido por um indivíduo e a subseqüente incidência e gravidade da fluorose (FEJERSKOV; THYLSTRUP $^{61}$, 1994; WHITFORD ${ }^{146}$, 1994; WHITFORD ${ }^{147}, 1994 ;$ DO CARMO et al. ${ }^{53}$, 1995; FEJERSKOV; BAELUM; RICHARDS ${ }^{62}$, 1996; WHITFORD ${ }^{148}$, 1996; BUZALAF; CURY; WHITIFORD ${ }^{33}$, 2001; PEREIRA ${ }^{108}$, 2001). Tendo um caráter dose-dependente, o aspecto clínico da fluorose está diretamente relacionado à interação das concentrações de flúor no 
plasma e o tempo (idade da criança e duração da exposição), podendo variar desde linhas brancas finas até um esmalte opaco e de aspecto calcáreo, que pode se fraturar após a erupção e/ou se pigmentar. A quantidade de ingestão diária de flúor, normalmente aceita como ideal para a prevenção da cárie e segura para a de fluorose, é de 0,05 a 0,07 mg de F/Kg massa corporal (BURT ${ }^{29}$, 1992; BUZALAF; CURY; WHITIFORD ${ }^{33}$, 2001).

A partir de 6 meses de idade, inicia-se o processo de erupção dos primeiros dentes da criança. Uma vez que a fluorose é um distúrbio na formação do dente, em decorrência da ingestão excessiva de flúor durante o seu período de desenvolvimento, a prevenção deve se concentrar em crianças com menos de 6 anos de idade (THYLSTRUP; FEJERSKOV ${ }^{133}$, 1978; ANGMAR-MÂNSSON; WHITFORD ${ }^{2}$, 1990; BURT ${ }^{29}$, 1992; LEWIS; BANTING ${ }^{82}$, 1994; FEJERSKOV; THYLSTRUP ${ }^{61}$, 1994; HOROWITZ ${ }^{74}$, 1996; ASSIS et al. ${ }^{5}$, 1999; BUZALAF; CURY; WHITIFORD $\left.{ }^{33}, 2001\right)$. EVANS e DARVELL, em 1995, sugeriram que o período de risco para a fluorose dos incisivos centrais superiores compreende-se entre 15 e 24 meses para os meninos e, entre 21 e 30 meses para as meninas. Recentemente questionou-se este período para os incisivos centrais superiores (BARDSEN $\left.{ }^{7}, 1999\right)$. Em geral, os dentes posteriores são os mais afetados em regiões com alta concentração de flúor, enquanto que em regiões com baixa concentração de flúor, os pré-molares e os segundos molares são os mais afetados (THYLSTRUP; FEJERSKOV $\left.{ }^{133}, 1978\right)$.

Embora a água seja uma importante fonte de ingestão de flúor, outras fontes estão disponíveis, como os dentifrícios, géis, soluções para 
bochecho, bem como sucos, bebidas, alimentos e fórmulas infantis, preparados com a água fluoretada. Até a década de 70 , a única fonte de exposição sistêmica coletiva ao flúor era a água fluoretada, no entanto, a partir da década de 90, o dentifrício fluoretado passou a ter uma importante participação, tendo em vista à sua ingestão por crianças durante a escovação (LIMA; CURY ${ }^{83}$, 2001). Para os profissionais de saúde é importante uma avaliação do consumo total de flúor, bem como dos fatores ambientais que podem influenciar na sua absorção e excreção (BURT ${ }^{29}$, 1992; ASSIS et al. $^{5}$, 1999; BUZALAF; CURY; WHITIFORD ${ }^{33}, 2001$; BUZALAF et al. $\left.{ }^{34}, 2002\right)$.

A fluorose dentária não é um efeito colateral decorrente da fluoretação da água em concentração ótima. Portanto, com relação a riscos à saúde é um método seguro. Um dos parâmetros de segurança é a avaliação da excreção urinária de flúor. Assim, de acordo com a Portaria N 12 do Ministério do Trabalho do Brasil, 3,0 mg F/L é o Limite de Tolerância Biológica (LTB) estabelecida para a avaliação de exposição ocupacional. Sendo assim, o indivíduo adulto que excreta até este valor está num ambiente seguro em termos de saúde geral. Em uma população ingerindo água fluoretada numa concentração de $0,7 \mathrm{mg}$ F/L, a excreção urinária normalmente deverá estar em torno do mesmo valor. Portanto, a quantidade excretada é no mínimo 4 vezes inferior ao LTB. Considerando a relação direta entre a concentração de flúor ingerido pela água e a excreção pela urina e, ainda que o efeito é cumulativo em termos de concentração óssea decorre da dose ingerida, para se observar algum efeito colateral no esqueleto humano esperado para uma ingestão de $3 \mathrm{mg} F / L$, numa 
população que ingere água fluoretada a 0,7 mg/L, seria necessário que esta atingisse 260 anos de idade $\left(C U R Y^{49}, 1992\right)$. Assim, para que o efeito de 0,7 mg F/L corresponda ao de 3,0 mg F/L seria necessário ingerir flúor por um perído de tempo correspondente a relação de 3 para 0,7 que é 4 vezes mais. Para o indivíduo de 260 anos, o esqueleto começaria a apresentar os primeiros efeitos colaterais do flúor, para a saúde geral, com significado clínico semelhante ao da fluorose dentária quando ingerido na concentração ótima (CURY ${ }^{49}, 1992 ; B^{2}$ ENDIA $\left.{ }^{28}, 1997\right)$.

Ainda com relação a possívies efeitos colaterais do flúor, de acordo com a American Dental Association (ADA), nenhum dos estudos já realizados permite supor que a fluoretação está associada a um aumento na ocorrência ou na mortalidade por câncer (PINTO ${ }^{110}$, 1993). Segundo a Federation Dental International (FDI), após 9 meses de pesquisa um Comitê de Especialistas do Serviço de Saúde Pública dos Estados Unidos, concluiu que a fluoretação da água não é carcinogênica e que esta medida é segura e eficaz na prevenção da cárie dentária (VIEGAS et al. ${ }^{140}$, 1987; PINTO ${ }^{110}$, 1993; CURY50, 2001). 


\subsection{Considerações GeRAIS}

A fluoretação da água de abastecimento público deve ser considerada como uma atividade de caráter multiprofissional, da qual devem participar dentistas, engenheiros, químicos, nutricionistas, médicos e outros profissionais do setor da saúde. Embora as principais tarefas de fluoretação fiquem sob a responsabilidade de nutricionistas e engenheiros, é extremamente importante que outros grupos participem em todos os aspectos do programa, como promoção, planejamento, financiamento, implementação, funcionamento, manutenção e vigilância (MURRAY ${ }^{93}$, 1992).

O equipamento e os fluoretos que serão utilizados em um programa de fluoretação de água dependerão das circunstâncias e características próprias de cada local. Ao projetar um sistema de fluoretação, antes de se definir o produto químico de escolha como fonte do íon flúor deve-se considerar o tipo de equipamento de fluoretação que será instalado. Por exemplo, com fluoreto de sódio granulado usa-se um saturador, com fluorsilicato ou fluoreto de sódio, um distribuidor seco e, com ácido hidrofluossilícico, um distribuidor líquido (MURRAY $\left.{ }^{93}, 1992\right)$. Além destes aspectos, o teor de flúor presente naturalmente na água deve ser avaliado antes de se estabelecer a quantidade a ser adicionada, quando necessário para se obter o nível ótimo (VIEGAS ${ }^{137}, 1961$; SPEARS ${ }^{128}$, 1991; MURRAY $^{93}$, 1992; CALVO ${ }^{36}$, 1996; SAMPAIO et al. ${ }^{117}$, 2000; EKANAYAKE; HOEK $^{56}$, 2002; SANTOS et al. ${ }^{120}$, 2003).

O flúor constitui $0,08 \%$ do córtex terrestre, sendo o $13^{\circ}$ elemento por ordem de abundância. Sua forma elementar é desconhecida na 
natureza, sendo que os minerais mais abundantes são o espato-flúor (fluorita), a criolita e a apatita. O ácido fluorídrico é um composto formado a partir da fluorita e é utilizado para formar outros compostos ou diretamente na fluoretação da água; contudo, é altamente corrosivo e de difícil manipulação. O fluoreto de sódio é mais caro, tem alta solubilidade e maior facilidade de manipulação. A partir de compostos de flúorsilicato são obtidos subprodutos como o ácido fluossilícico e o flúorsilicato de sódio (que podem ser utilizados na fluoretação das águas) e outros como o flúorsilicato de amônia e de magnésio. Já a criolita não é utilizada na fluoretação devido ao seu alto custo (BRASIL ${ }^{20}, 1975 ;$ MURRAY $\left.^{93}, 1992\right)$.

TABELA 2 - Os compostos de flúor mais utilizadados na fluoretação da água de abastecimento público no Brasil

\begin{tabular}{|c|c|c|c|c|}
\hline Características & $\begin{array}{c}\text { Fluoreto } \\
\text { de Cálcio } \\
\text { (Fluorita) } \mathrm{CaF}_{2}\end{array}$ & $\begin{array}{l}\text { Fluossilicato } \\
\text { de Sódio } \\
\mathrm{Na}_{2} \mathrm{SiF}_{6}\end{array}$ & $\begin{array}{c}\text { Fluoreto } \\
\text { de Sódio } \\
\text { NaF }\end{array}$ & $\begin{array}{c}\text { Ácido Fluossilícico } \\
\qquad \mathrm{H}_{2} \mathrm{SiF}_{6}\end{array}$ \\
\hline Forma & Pó & Pó ou cristal fino & Pó ou cristal & líquido \\
\hline Peso Molecular & 78,08 & 188,05 & 42 & 144,08 \\
\hline Pureza Comercial & 85 a 98 & 98 a 99 & 90 a 98 & 22 a 30 \\
\hline Solubilidade gr/100 $\left(25^{\circ} \mathrm{C}\right)$ & 0,0016 & 0,762 & 4,05 & \\
\hline pH da solubilidade saturada & 6,7 & 3,5 & 7,6 & 1,2 (solução 1\%) \\
\hline íon fluoreto em \% (100\% puro) & 48,8 & 60,7 & 52,25 & 79,2 \\
\hline
\end{tabular}

Fonte: PORTARIA N 635/BSB, de 26 de dezembro de 1975.

Toda estação de tratamento deve ter um sistema de controle permanente do teor de flúor na água através da quantidade de sal gasto, que pode ser realizado através do uso de balanças ou alimentadores automáticos gravimétricos ou ainda, através da verificação do nível da solução nos tanques dosadores volumétricos, onde a quantidade de água é fornecida pelo medidor principal da estação. Porém, o mais indicado é fazer a verificação direta do teor de flúor na água através de amostras coletadas 
na estação de tratamento, nos depósitos principais e em vários pontos da rede de distribuição. Para se analisar o teor de flúor na água existem vários métodos, sendo que os colorimétricos, onde reagentes apropriados são misturados à água e, dependendo de sua coloração, é determinada a quantidade de flúor (Método Scott-Sanchis e Método Megregian-Maier), são muito usados. Existem, ainda, medidores eletrônicos que utilizam dois eletrodos, tendo leitura rápida e precisa (MURRAY $\left.{ }^{93}, 1992\right)$.

Para que a eficácia do sistema de fluoretação seja sempre máxima, é necessário observar a manutenção minuciosa do equipamento de fluoretação e controlar a dosificação do produto químico para manter uma correção uniforme do íon flúor em todos os momentos e em todas as partes da rede. O controle analítico na estação de tratamento consiste em determinar o conteúdo de flúor na água quando esta sai da estação e, também, da rede de distribuição de água. Estes controles podem ser feitos utilizando um eletrodo de ionização específico. A análise permanente do conteúdo de flúor da água é essencial para determinar se a fluoretação está sendo realizada na concentração ótima. Toda variação do nível de flúor deve ser prontamente corrigida pelo operador. Recomenda-se que a água que sai da estação de tratamento seja analisada várias vezes ao dia e, pelo menos, uma vez ao dia, a água da rede de distribuição. Deve-se fazer ainda um controle da qualidade das análises. A cada mês, a autoridade competente deve enviar três amostras dos lotes previamente analisados, sem identificação, para uma nova análise, verificando desta forma se há coincidência dos resultados (MURRAY $\left.{ }^{93}, 1992\right)$. 
Os procedimentos de fluoretação dependem do composto utilizado. Para o flúor silicato de sódio, os dosadores podem ser a seco ou de solução, sendo que os dosadores a seco podem ser gravimétricos ou volumétricos. No Brasil, os mais utilizados são os volumétricos. A fluorita tem emprego restrito devido à sua baixa solubilidade, embora a sua prédissolução em tanques com sulfato de alumínio possibilite o aumento na velocidade de dissolução. Ela também pode ser utilizada diretamente nos filtros de areia ou fluorita microgranulada como outra alternativa nos sistemas de tratamento de água (MURRAY $\left.{ }^{93}, 1992\right)$.

Recentemente tem-se optado pelo uso do ácido fluossilícico, que é uma solução que pode ser dosada através de bombas apropriadas por hidro-ejetor ou dosador de nível constante. Entre as vantagens em se utilizar este composto está a de evitar os problemas inerentes à dosificação, como a obstrução da tubulação e o risco de pós tóxicos (MURRAY $\left.{ }^{93}, 1992\right)$.

A dosagem dos compostos é definida de acordo com a vazão do sistema e com a forma (pó ou líquido) que se apresenta o composto empregado na fluoretação da água (BRASIL ${ }^{20}$, 1975). Especificamente em Bauru o composto empregado é o ácido fluossilícico a 20\%, com dosagem por via úmida (BASTOS; FREITAS $\left.{ }^{11}, 1991\right)$. 
TABELA 3 - Características da dosagem por via úmida com o ácido fluossilícico, no Brasil, 2003

\begin{tabular}{|c|c|c|c|c|c|c|}
\hline $\begin{array}{l}\text { Composto } \\
\text { químico }\end{array}$ & $\begin{array}{l}\text { Vazão } \\
\text { L/s }\end{array}$ & $\begin{array}{l}\text { Equipamento } \\
\text { requerido }\end{array}$ & $\begin{array}{l}\text { Especidficação } \\
\text { do produto }\end{array}$ & Manuseio & $\begin{array}{l}\text { Ponto de } \\
\text { aplicação }\end{array}$ & Cuidados \\
\hline \multirow{2}{*}{$\begin{array}{c}\text { Ácido } \\
\text { fluossilícico }\end{array}$} & 30 & $\begin{array}{l}\text { dosador de solução } \\
\text { balança } \\
\text { tanque calibrado } \\
\text { tanque de mistura } \\
\text { misturador }\end{array}$ & $\begin{array}{l}\text { Ácido fortificado } \\
\text { (pouca sílica) em } \\
\text { tambores ou } \\
\text { bombonas }\end{array}$ & $\begin{array}{l}\text { despejo ou } \\
\text { sifonamento } \\
\text { medição } \\
\text { misturador } \\
\text { pesagem }\end{array}$ & \multirow{2}{*}{$\begin{array}{l}\text { Efluente do } \\
\text { filtro } \\
\text { Reservatório } \\
\text { de água } \\
\text { filtrada }\end{array}$} & $\begin{array}{l}\text { corrosão } \\
\text { vapores } \\
\text { respingos } \\
\text { preparo da } \\
\text { solução }\end{array}$ \\
\hline & 30 & $\begin{array}{l}\text { dosador de solução } \\
\text { tanque diário } \\
\text { balança } \\
\text { bomba para } \\
\text { transferência }\end{array}$ & $\begin{array}{l}\text { A granel em } \\
\text { vagões ou } \\
\text { caminhões }\end{array}$ & bombeamento & & $\begin{array}{c}\text { corrosão } \\
\text { vapores } \\
\text { vazamentos }\end{array}$ \\
\hline
\end{tabular}

Fonte: Portaria N 635/BSB, de 26 de dezembro de 1975.

A existência de um sistema centralizado de fornecimento de água de abastecimento bem estabelecido é um requisito essencial para a fluoretação da água. Embora a água seja uma das principais fontes de ingestão de fluoretos, deve-se levar em consideração outras fontes. Por exemplo, no Japão, consome-se muito peixe, chás e algas marinhas, hábitos que influenciam no ajuste do sistema de fluoretação desse país para 0,6 mg F/L. Além dos aspectos culturais que interferem nos hábitos de alimentação, o consumo de líquidos está relacionado com a temperatura ambiente, e desta forma o clima também exerce influência na quantidade de fluoretos ingerida diariamente através da água. Além da temperatura, a definição do nível ótimo de flúor na água, depende da pureza e tipo de sal de flúor que será adicionado à água e da quantidade de flúor, porventura, já existente na água (MURRAY $\left.{ }^{93}, 1992\right)$.

Nos climas temperados, a concentração ótima é de $1 \mathrm{mg}$ F/L. As taxas recomendadas revelam, como valores de segurança e praticidade de adição de flúor na água, a concentração de 0,7 a 1,2 mg F/L, numa média de 
0,8 mg F/L, variando com a temperatura do local. A OMS, em 1984, determinou uma concentração máxima de 1,5 mg F/L na água para evitar fluorose. Somente quando o flúor excede ao nível de 1,6 mg/L é que aparecem os primeiros sinais de manchas de fluorose (MURRAY $\left.{ }^{93}, 1992\right)$. A Portaria N 635/BSB, que normatiza a fluoretação de água no Brasil estabelece os limites mínimos e máximos de flúor aceitáveis (TABELA 4).

TABELA 4 - Limite recomendados para a concentração do íon fluoreto em função da média das temperaturas máximas diárias

\begin{tabular}{c|c|c|c}
\hline \multirow{2}{*}{$\begin{array}{c}\text { Média das temperaturas } \\
\text { máximas diárias }\end{array}{ }^{\circ} \mathbf{C}$} & \multicolumn{3}{|c}{$\begin{array}{c}\text { Limites recomendados para a } \\
\text { concentração de íons flúor em mg/L }\end{array}$} \\
\cline { 2 - 4 } & mínimo & máximo & ótimo \\
\hline $10,0-12,1$ & 0,9 & 1,7 & 1,2 \\
$12,2-14,6$ & 0,8 & 1,5 & 1,1 \\
$14,7-17,7$ & 0,8 & 1,3 & 1,0 \\
$17,8-21,4$ & 0,7 & 1,2 & 0,9 \\
$21,5-26,3$ & 0,7 & 1,0 & 0,8 \\
$26,4-32,5$ & 0,6 & 0,8 & 0,7 \\
\hline
\end{tabular}

Fonte: Portaria N 635/BSB, de 26 de dezembro de 1975.

Para que um município possa introduzir a fluoretação da água destinada ao abastecimento público é necessário que preencha os seguintes requisitos (MURRAY $\left.{ }^{93}, 1992\right)$ :

- Um grau suficiente de desenvolvimento econômico;

- Existência de uma rede municipal de abastecimento de água que alcance um grande número de residências;

- Ingestão constante por parte da população da água da rede municipal e não de poços ou cisternas;

- Existência de equipamento indispensável em uma estação de tratamento e bombeamento; 
- Fornecimento assegurado de um produto químico de flúor de qualidade aceitável;

- Existência de pessoal capacitado na estação de tratamento para manter o sistema e realizar os registros apropriados;

- Disponibilidade de capital suficiente para os gastos iniciais de instalação e funcionamento;

- Prevalência alta ou moderada de cárie dentária na coletividade ou indícios claros de que é cada vez maior;

- Legislação adequada que autorize a fluoretação.

Para que a fluoretação da água seja adequadamente implantada, além dos requisitos preenchidos, é importante que sejam considerados os seguintes aspectos gerais do sistema de fluoretação: (MURRAY $\left.{ }^{93}, 1992\right)$

- O equipamento de fluoretação deve adaptar-se às condições e às necessidades locais da rede de abastecimento de água;

- O equipamento deve ser eficaz, seguro e preciso em todas as condições climáticas;

- Deverá ser um tipo padronizado, reconhecido como satisfatório e de fácil manutenção;

- A escolha do distribuidor deve basear-se na quantidade e no tipo do produto portador de flúor que será utilizado;

- O equipamento deverá ser de precisão bem delimitada, ou seja, independentemente da variação de quantidade de água tratada, não podem ser produzidos erros maiores do que $5 \%$ em todo o sistema. Para evitar todo o excesso de dosificação, deverá possuir um 
mecanismo de segurança que detenha automaticamente a adição do flúor quando diminuir, bruscamente, a passagem de água pela estação de tratamento;

- O ajustamento dos distribuidores deve ser suficientemente fácil e rápido;

- O aparelhamento deve funcionar entre 20 e $80 \%$ de sua capacidade total, medida de segurança que permite uma dosificação máxima de flúor de até 5 vezes o nível ótimo em caso de defeito grave de funcionamento. Esse nível é considerado inócuo por um breve período;

- Em cada sistema de fluoretação convém instalar um mecanismo de ação anti-sifônica nos tubos de distribuição da solução de flúor na água, para evitar a entrada de uma solução concentrada no sistema de distribuição.

A fluoretação da água de abastecimento público é recomendada e apoiada por mais de 150 organizações científicas, sanitárias e políticas. É um método indicado para países com um bom nível de desenvolvimento econômico, pois só é prático se: existe abastecimento municipal de água para número suficiente de moradias; a população bebe desta água, ao invés da água de poços e cisternas; existe o equipamento adequado em uma estação de tratamento e bombeamento; está assegurado um produto químico de flúor adequado; há operadores capazes de fazer a manutenção do sistema e registros corretos; existem recursos suficientes para a instalação inicial do equipamento (MURRAY $\left.{ }^{93}, 1992\right)$. 
O Serviço de Saúde Pública dos EUA estimou em U\$0.35 (trinta e cinco centavos de dólar) o custo da fluoretação por pessoa por ano em 1981. Este custo pode oscilar entre 0.20 e 0.40 dólares, para grandes cidades, enquanto que para pequenas pode variar entre 0.50 a 2.50 dólares. Estes valores, normalmente, superestimam os gastos diretos reais, pois foram obtidos a partir da divisão do custo total do equipamento, das instalações e do produto químico utilizado em um ano totalizados pelo número de habitantes que recebem a água de abastecimento fluoretada. $\mathrm{O}$ equipamento de fluoretação pode durar de 10 a 15 anos. Quanto maior a população, menor o custo per capita da fluoretação. Segundo BURT, o custo médio nos Estados Unidos é cerca de US\$0,51 (MURRAY $\left.{ }^{93}, 1992\right)$.

No Brasil, estima-se que o custo per capitalano da fluoretação da água, seja em torno de $\mathrm{R} \$ 1,00$. Manter um indivíduo beneficiado pela fluoretação de água, ao longo de toda sua vida, é a melhor relação de custobenefício, dentre todas atividades voltadas para a prevenção da cárie, pois custa o equivalente a uma restauração dentária (NARVAI $\left.{ }^{98}, 2001\right)$.

Existem questionamentos quanto à necessidade de fluoretação da água. Quando indivíduos residem em comunidades que são suficientemente fluoretadas através de outras fontes que não a água, então qual a necessidade de se fluoretar a água? Devido a isso, discute-se que poderia não ser apropriada a fluoretação da água em comunidades com baixa incidência de cárie, pois os custos seriam altos em comparação aos benefícios esperados. Os diversos trabalhos na literatura acerca deste assunto são bastante controversos: alguns encontraram menor prevalência de cárie em regiões fluoretadas, outros maior incidência de cárie em cidade 
fluoretada, mas o debate em questão parte de achados de pesquisas que vêm relatando pequenas diferenças entre a prevalência de cárie dentária em cidades fluoretadas e não fluoretadas. Isto se deve à crescente introdução de produtos fluoretados no mercado, bem como ao "efeito halo", ou seja, cidades não fluoretadas que consomem produtos fabricados em cidades fluoretadas, como bebidas, por exemplo (SALES PERES ${ }^{118}, 2001$; SEPPÄ et al. $\left.{ }^{122}, 2002\right)$.

O efeito da fluoretação da água de abastecimento público tem sido diluído por outras medidas para o controle da doença, e o impacto ("atenuação da força do método") foi reduzido a valores em torno de $20 \%$ com tendência a continuar decrescendo. Este fato é decorrente de dois fenômenos: a diluição e a difusão. O primeiro é a aparente redução dos benefícios resultantes da fluoretação da água de abastecimento, devido ao aumento de fontes de ingestão de flúor (géis, soluções para bochecho, dentifrícios, suplementos sistêmicos). Este fenômeno tem sido confirmado por estudos onde se constatou uma diferença muito pequena entre os índices de localidades com fluoretação ótima e deficiente (BUZALAF ${ }^{32}$, 1996; HOROWITZ ${ }^{74}, 1996$; CURY $\left.{ }^{50}, 2001\right)$. Portanto, o uso destes produtos reduz a prevalência de cárie em ambas as populações, reduzindo a diferença existente do índice de cáries entre as cidades com água fluoretada e não fluoretada. O segundo fenômeno, a difusão corresponde à extensão dos benefícios da fluoretação da água de abastecimento público de uma determinada cidade, para as residências de cidades não fluoretadas. O consumo de produtos industrializados, processados com água fluoretada, como bebidas e alimentos, por uma comunidade que não recebe água de 
abastecimento público fluoretada $\left(\right.$ RIPA $^{116}, 1993 ;$ BUZALAF $^{32}, 1996$; HOROWITZ ${ }^{74}, 1996$; CURY $\left.^{50}, 2001\right)$.

De acordo com estudos feitos com critérios fixados pela OMS e pela FDI, a fluoretação ótima da água é altamente eficaz, sendo que a redução mais frequente na prevalência de cárie dos dentes decíduos oscila entre 40 e $50 \%$ e, dos dentes permanentes, entre 50 e 60\%. Foram estabelecidas relações entre a redução da cárie nas dentições temporárias e permanentes com o menor ritmo de progressão das lesões causadas por esta afecção, com a diminuição da frequência com que é afetada a polpa dentária e com o número crescente de indivíduos cuja dentição está isenta de cárie. Estes efeitos são observados em todas as populações que se beneficiam da fluoretação da água, independentemente de classe social (THYLSTRUP ${ }^{134}, 1990 ;$ MURRAY $\left.^{93}, 1992\right)$.

É da maior importância assegurar de modo permanente o aporte de fluoretos em concentrações ótimas na água de abastecimento. Segundo os resultados de estudos a longo prazo, o efeito anti-cárie pode diminuir ou desaparecer por completo se a fluoretação da água for interrompida (CHAVES et al. ${ }^{42}$, 1953). Após 5 anos de paralisação da fluoretação na cidade de Wick, na Escócia, constatou-se um aumento no índice de cárie, na dentição decídua, de 40\% (STEPHEN; McCALL, 1987; THYLSTRUP ${ }^{134}$, 1990). Situação semelhante foi verificada nos Estados Unidos, onde as crianças de cidades com água fluoretada apresentaram cerca de 18 a 25\% menos cárie (BRUNELLE; CARLOS $\left.{ }^{26}, 1990\right)$.

A fluoretação da água continua sendo uma estratégia de relevante custo-benefício para prevenção de cárie dentária mesmo onde tenha sido 
observado um acentuado declínio da prevalência de cárie dentária nos últimos anos (O'MULLANE ${ }^{100}, 1990 ;$ THYLSTRUP $\left.^{134}, 1990\right)$. Daí, a grande importância da manutenção da regularidade da concentração ótima de flúor na água em termos de benefícios, principalmente considerando as particularidades do Brasil (VIEGAS ${ }^{140}$, 1987; CURY $^{49}$, 1992; NARVAI ${ }^{98}$, 2001).

A oficialização de um sistema de vigilância sanitária que controle a concentração do flúor na água, assim como sua freqüência, a adoção de estratégias específicas para quebrar as barreiras da expansão e maior divulgação dos dados epidemiológicos, comparando cidades fluoretadas com não-fluoretadas, assegurariam argumentos para a sociedade exigir seus direitos com relação a fluoretação $\left(C U Y^{49}, 1992\right)$. 


\subsection{LegISLAÇÃo}

A legislação relativa à fluoretação das águas de abastecimento público pode ser de dois tipos. Pode ser vinculante, obrigando o Ministério da Saúde ou as coletividades de determinada magnitude à fluoretação da água de abastecimento público, se esta é pobre em flúor. Pode, também, limitar-se a permitir ou autorizar o Ministério da Saúde ou ao Governo local à prática da fluoretação (MURRAY93, 1992).

A legislação que permite ou autoriza, mas não torna obrigatória a implantação da fluoretação, faculta às autoridades nacionais de saúde ou aos governos locais o estabelecimento de fluoretação da água de abastecimento público, envolvendo duas classes: uma autoriza a ação dos funcionários de saúde e a outra autoriza a atividade ou atuação dos funcionários da administração local. Este tipo de legislação existe na Austrália, na República Democrática Alemã, em Israel, na Holanda, e em outros países (MURRAY $\left.{ }^{93}, 1992\right)$.

No Brasil, na Bulgária, na Grécia, na Irlanda e em seis estados dos EUA e em Washington foram promulgadas leis que impõem a fluoretação da água de abastecimento público pobre em fluoreto. O Brasil foi um dos primeiros países da América Latina a estabelecer a fluoretação da água. Desde 1974, o Minstério da Saúde está autorizado a estabelecer normas e critérios nacionais sobre a fluoretação, tendo em conta o conteúdo natural de fluoretos da água potável, o estado de saúde buco-dental da população, entre outros aspectos (MURRAY $\left.{ }^{93}, 1992\right)$.

A partir de 1974, a fluoretação da água de abastecimento público passa a ser obrigatória no Brasil, onde existe Estação de Tratamento de 
Água (ETA), e é regulamentada por meio de legislação. A Lei Federal N 6.050, de 24 de maio de 1974, dispõe sobre a fluoretação da água em sistemas públicos de abastecimento, sendo devidamente regulamentada pelo Decreto Federal $n^{\circ}$ 76.872, de 22 de dezembro de 1975, que dispõe sobre a obrigatoriedade da fluoretação, estabelecendo que "os projetos destinados à construção ou ampliação de sistemas públicos de abastecimento de água, onde haja estação de tratamento, devem incluir previsões e planos relativos à fluoretação de água" (BRASIL ${ }^{17}, 1974$; BRASIL $\left.^{18}, 1975\right)$. Por sua vez, a operacionalização da medida tem seus padrões definidos pela Portaria do Ministério da Saúde nº 635/BSB, de 26 de dezembro de 1975, que aprova e determina normas e padrões a serem seguidos, desde a concentração do íon flúor a ser utilizado, de acordo com as médias das temperaturas máximas anuais de cada região, até os compostos recomendados, para a correta implementação da fluoretação das águas de abastecimento (BRASIL $\left.{ }^{19}, 1975\right)$. Esta portaria dispõe entre outros itens sobre a concentração de íon fluoreto que representa a relação estabelecida entre a massa de íon fluoreto dissolvido na água e a massa da solução, normalmente expressa em partes por milhão (ppm) que representa miligramas de íon flúor por quilograma de solução. Para um melhor entendimento desta norma admite-se que 1 litro de água, pesa 1 quilograma; portanto ppm=1mg/litro $\left(\right.$ BRASIL $\left.^{19}, 1975\right)$.

No Estado de São Paulo, a Resolução SS-250/95, de 15/08/95 estabelece que as águas dos municípios do referido Estado devem conter 0,7 miligramas de flúor por litro $(0,7$ ppm) e define como aceitável, uma variação entre 0,6 a 0,8 mg/L, no teor de flúor. De acordo com o documento, 
teor de flúor abaixo ou acima desse intervalo caracteriza água fora do "Padrão de Potabilidade", portanto, inaceitável para o consumo humano do ponto de vista de prevenção da cárie e da fluorose dentária (SÃO PAULO ${ }^{121}$, 1995).

A mais recente legislação relativa à água de abastecimento dispõe que, são pertinentes à Portaria do Ministério da Saúde nº 518, de 25 de março de 2004, e Decreto $n^{\circ}$ 79.367, de 9 de março de 2004, os procedimentos e as responsabilidades relativas ao controle e à vigilância da qualidade da água para o consumo humano e seu padrão de potabilidade (BRASIL $\left.{ }^{25}, 2004\right)$.

A Vigilância Sanitária, de acordo com a Lei Federal, 8.080, de 19/09/1990, é definida como "um conjunto de ações capaz de eliminar, diminuir ou prevenir riscos à saúde e de intervir nos problemas sanitários decorrentes do meio ambiente, da produção e circulação de bens e da prestação de serviços de interesse da saúde" (BRASIL $\left.{ }^{20}, 1990\right)$. Segundo NARVAI, a Vigilância Sanitária é um dos pilares da Saúde Pública e propõe que, na área da saúde bucal coletiva e da área de atuação odontológica, suas ações abranjam três dimensões: "os estabelecimentos de prestação de serviços odontológicos, os produtos para higiene bucal, e os alimentos e bebidas" (NARVAI $\left.{ }^{98}, 2001\right)$.

O Sistema de Vigilância Sanitária Brasileiro foi reestruturado através da Lei no 9.782, de 25/10/1999, quando foi criada a Agência Nacional de Vigilância Sanitária (ANVISA), cuja finalidade institucional é a de "promover a proteção da saúde da população por intermédio do controle sanitário da produção e da comercialização de produtos e serviços 
submetidos à vigilância sanitária, inclusive dos ambientes, dos processos, dos insumos e das tecnologias a eles relacionados" (ANVISA $\left.{ }^{3}, 2001\right)$. Sendo o flúor um elemento químico e, que por estar presente em diversos produtos, como água de abastecimento público, água engarrafada, bebidas, sucos, refrigerantes, em alimentos, e em alguns medicamentos e suplementos nutricionais, o controle e a manutenção da sua concentração adequada, são de interesse da Vigilância Sanitária (OMS ${ }^{105}$, 1972; MURRAY ${ }^{93}$, 1992; BASTOS; LOPES; FREITAS ${ }^{12}$, 1993; PINTO ${ }^{110}, 1993$; NARVAI $\left.{ }^{98}, 2001\right)$

O Comitê Técnico-Científico de Assessoramento à Área Técnica de Saúde Bucal, do Ministério da Saúde do Brasil, com o objetivo de esclarecer seu posicionamento favorável sobre o método de fluoretação da água de abastecimento público, elaborou um parecer com as seguintes observações $\left(\mathrm{CTCSB}^{45}, 2001\right)$ :

1. "Tal método é recomendado por mais de 150 organizações de ciências e saúde, incluindo a Federação Dentária Internacional (FDI), a Associação Internacional de Pesquisa em Odontologia (IADR), a Organização Mundial da Saúde (WHO) e a Organização PanAmericana de Saúde (OPAS);

2. Programas de fluoretação da água têm sido implementados em aproximadamente 39 países, atingindo mais de 200 milhões de pessoas. Acrescente-se a isto um adicional estimado de outras 40 milhões que ingerem água naturalmente fluoretada; 
3. No Brasil, este método está regulamentado pelo Decreto N 76.872 de 22 de dezembro de 1975 e é considerado pelo Ministério da Saúde o Programa Básico Coletivo para Prevenção de Cárie no país. Sua implementação é apoiada por todas as Associações de Classe da Odontologia brasileira: Conselho Federal de Odontologia (CFO), Associação Brasileira de Odontologia (ABO), Federação Nacional dos Odontologistas (FNO), Associação Brasileira de Ensino Odontológico (ABENO), Academia Brasileira de Odontologia, entre outras;

4. Estima-se que aproximadamente 65 milhões de brasileiros estão sendo atualmente beneficiados pela agregação de flúor ao tratamento da água com resultados comprovados de eficiência do método;

5. A segurança da agregação de flúor ao tratamento de água é incontestável e reconhecida mundialmente. Os níveis de fluorose dental decorrentes de ingestão de água fluoretada na concentração ótima não têm qualquer significado em termos de saúde pública;

6. A fluoretação da água é um método que beneficia toda a população e principalmente a de menor nível sócio-econômico;

7. Este método, possibilita a manutenção de concentrações baixas e constantes concentrações de flúor na cavidade bucal para controlar o desenvolvimento da cárie. Assim, beneficia não só crianças como adultos que continuamente ingerem água fluoretada durante toda a vida;

8. Embora tenha havido no Brasil uma mudança positiva do quadro epidemiológico relativo à cárie dental, os dados mostram padrões melhores de Saúde Bucal onde a água é fluoretada. Assim, a água 
fluoretada ainda é um método coletivo indispensável para o país. Deve ser destacado que mesmo nos países onde houve, por outras causas, um significativo declínio de cárie nos últimos anos, água fluoretada ainda continua sendo utilizada na maioria deles;

9. Para garantir os benefícios deste método com segurança em relação à fluorose dental, recomenda-se:

a) Oficializar um programa de heterocontrole da concentração de flúor na água;

b) Controlar as outras fontes de exposição sistêmica a flúor, principalmente a ingestão de dentifrícios por crianças e o uso inadequado de medicamentos fluoretados;

c) Fazer levantamentos epidemiológicos de cárie e fluorose dental antes e depois da implementação do método.

Assim sendo, ratifica-se o entendimento segundo o qual não fluoretar a água no Brasil ou interromper sua continuidade deve ser considerada uma atitude juridicamente ilegal, cientificamente insustentável e socialmente injusta." 


\subsection{A fluoretação da Água de Abastecimento Público No MUNDO}

Entre os programas que alcançaram maior êxito, está o de Hong Kong e Singapura, onde a fluoretação da água é quase geral, na República da Irlanda, onde, aproximadamente, $70 \%$ da população se beneficia da fluoretação da água de abastecimento, em Porto Rico 63\%, nos EUA 51\%, na Austrália 50\%, na Nova Zelândia 50\%, no Canadá 28\% e a na GrãBretanha 12\%. Nos países da América Central e do Sul, na Austrália, Nova Zelândia e Malásia, também foram realizados progressos com relação à fluoretação (MURRAY93, 1992$)$.

NA AustráliA, a fluoretação da água é uma medida de saúde pública adotada desde 1964. Em 1977, sete de oito capitais de estado implementaram a fluoretação da água de abastecimento público, e por volta de $1984,65,8 \%$ da população australiana viviam em regiões com água fluoretada. Durante os anos 80 , estudos epidemiológicos mostraram baixa experiência de cárie em crianças que consumiram água fluoretada por toda vida em comparação com aquelas que não o fizeram. Em 1995, buscou-se verificar a relação existente entre experiência de cárie em crianças e a exposição ao flúor, em dois estados da Austrália. Em ambos, verificou-se uma redução no ceos em relação ao tempo de exposição ao flúor, concordando com a hipótese de uma relação linear entre experiência de cárie dentária e a porcentagem do tempo de vida de exposição à água fluoretada (SLADE et al. ${ }^{125}$, 1995).

No CanadÁ, com a finalidade de avaliar a necessidade de fluoretação da água de abastecimento de Truro, um levantamento 
epidemiológico foi planejado estabelecendo uma comparação entre a prevalência de cárie dentária e a de fluorose, entre crianças moradoras de uma cidade fluoretada, Kentville (1,1 mg/L), e de uma cidade não fluoretada, Truro $(<0,1 \mathrm{mg} / \mathrm{L})$. Paralelamente aos exames, os pais responderam a questionários que investigavam as fontes de água de beber utilizadas pelas crianças desde o nascimento, a história de onde residiram, o uso de suplementos fluoretados, de dentifrícios ou de outros produtos fluoretados durante os seis primeiros ano de vida. As diferenças de CPOS não foram consideradas estatisticamente significantes. Entretanto, a fluorose dentária estava presente em $41,5 \%$ das crianças residentes na região não fluoretada e em $69,2 \%$ das crianças residentes na região fluoretada. Os achados deste estudo epidemiológico e de outros, demonstraram que a relação entre cárie dentária e fluoretação de água não era clara até o ano de 1990, pois ainda não estava estabelecida uma separação entre os efeitos das diversas fontes de ingestão de flúor sistêmico e tópico. Portanto, há a necessidade de se reavaliar os benefícios da fluoretação da água como parte de um programa de saúde bucal, uma vez que, embora a fuoretação da água tenha influênciado poisitivamente na redução da prevalência de cárie dentária entre as crianças de alto risco, as crianças expostas à água fluoretada desde o nascimento, não tiveram uma redução adicional de cárie dentária em função do flúor na água, quando se considerou a utilização de dentifrícios fluoretados. Sendo assim, a fluoretação da água ainda é um programa preventivo ideal quando se considera a relação custo-benefício, entretanto pode não ser necessária em todas as comunidades, especialmente naquelas onde a prevalência de cárie da comunidade é baixa. A efetividade 
da fluoretação da água mostrou-se reduzida, considerando as crianças do grupo não fluoretado que já estavam expostas a outras fontes de ingestão de flúor. Cerca de $75 \%$ do flúor ingerido pelas crianças vem de sucos e bebidas e não da água de beber, e estes produtos constituem fontes adicionais de flúor em uma área fluoretada. A fluoretação da água deve ser promovida depois de se avaliar a quantidade de flúor presente em alimentos e bebidas, o uso de outros produtos fluoretados e, quando a fluoretação da água é indicada, deve-se definir uma concentração ótima de flúor na água de abastecimento público, considerando-se estes fatores (ISMAIL et al. ${ }^{75}$, 1993).

Nos Estados Unidos, em 1945, começaram os primeiros estudos de fluoretação artificial da água e a primeira cidade do mundo a ter suas águas de abastecimento fluoretadas, foi Grand Rapids. O efeito protetor da água fluoretada contra a cárie é incontestável. Exemplo disto é a cidade de Antigo, Wisconsin, EUA, que em 1960 interrompeu a fluoretação e o índice de cárie na dentição decídua aumentou em até 112\%, em 6 anos. Por isso, em 1965 a comunidade voltou a ser beneficiada por tal método. O advento do dentifrício fluoretado trouxe uma contribuição significativa, mas a fluoretação da água continua sendo importante, até em países desenvolvidos. No último levantamento nacional, realizado nos Estados Unidos, observou-se que as crianças de regiões fluoretadas apresentaram de 18 a 25\% menos cárie que as residentes em áreas não fluoretadas. Tais dados mostram a importância do método, principalmente num país com as características como as do Brasil (BRUNELLE; CARLOS ${ }^{26}$, 1990; CURY $^{49}$, 1992). 
O Centro de Ciências de Saúde do Departamento de Odontologia da Universidade do Texas, Houston, coletou amostras de água de agosto de 1988 a dezembro de 1991, semanalmente, nas torneiras da cidade de Houston. Analisaram a concentração de flúor na água durante um período de três anos, quando foi constado um declínio na concentração de flúor na água variando de um máximo de 0,92 mg/L em 1988 para um mínimo de 0,51 mg/L durante os primeiros oito meses de 1991. A menor concentração encontrada foi de 0,32 mg/L, no mês de agosto de 1991. Quando da realização da pesquisa, a cidade de Houston tinha 195 poços (a maioria com baixos níveis de flúor) que forneciam água para uma central, onde apenas a água de superfície era fluoretada. Estando a água de superfície adequadamente fluoretada e monitorada, os níveis de flúor na água que se apresentaram abaixo do nível ótimo de $0,7 \mathrm{mg} / \mathrm{L}$, seriam decorrentes provavelmente desta mistura da água de superfície fluoretada com a água provenientes dos poços (não fluoretada). Como os níveis de flúor da água de Houston se mostraram inconstantes, os profissionais de saúde (médicos e odontopediatras) tinham dificuldades na prescrição de uma dosagem adequada de suplementos de flúor, pois uma super ou subdosagem pode provocar fluorose ou aumento do risco de cárie, respectivamente. Desta forma, se as flutuações nos níveis de flúor na água de abastecimento observadas neste estudo são uma ocorrência comum entre outras comunidades com água fluoretada, faz-se necessário uma melhoria no equipamento de dosagem de flúor, programas de treinamento para os operadores das centrais de tratamento de água e o monitoramento e vigilância mais rigorosos da fluoretação de água (CHAN et al. ${ }^{39}$, 1993). 
As metas dos níveis de fluoretação de água da Califórnia de 1992-1993, foram desenvolvidas baseando-se na Academia Americana de Odontologia Pediátrica, que se orienta através dos níveis de flúor relatados pelas Centrais de Abastecimento de Água. Para comparar o teor de flúor de amostras de água obtidas em 45 residências em Los Angeles com os níveis de flúor relatados pelas Centrais de Abastecimento de Água, foram feitas coletas nas segundas, quartas e sextas-feiras de 11 a 29 de maio de 1992 , sendo 9 amostras de cada local. Observou-se uma grande variação nos níveis de flúor de 0,27 a 0,72 mg/L, numa média de 0,53 mg/L. Os resultados mostraram valores consistentemente mais altos do que os fornecidos pelas Centrais de Abastecimento, sendo que alguns excederam o nível ótimo. O conhecimento de todas as fontes de ingestão de flúor é difícil, ou mesmo impossível, mas antes de prescrever suplementos de flúor, devese considerar todas essas fontes, além da concentração de íon flúor na água de abastecimento, para evitar a fluorose (DUPERON; JEDRYCHOWSKI; $\left.\mathrm{KONG}^{54}, 1995\right)$.

A prevalência de cárie e fluorose dentária, foi avaliada em 344 crianças, entre 7 e 14 anos de idade, residentes em comunidades de Indiana, EUA, onde a concentração de flúor natural na água apresentava variações entre níveis menores (0,2 mg/L), ótimos (1,0 mg/L) e quatro vezes a dose ideal (4,0 mg/L). O CPO-D médio, das crianças na região não fluoretada foi de 3,68, e, de 3,34 e 2,95 nas regiões otimamente fluoretada e superfluoretada, respectivamente. A média do CPO-D da região otimamente fluoretada, não apresentou diferença significativa com relação às das outras regiões. No entanto, houve uma diferença significante entre a região super 
fluoretada e a não fluoretada. Os resultados sugerem que a ingestão de água com $1 \mathrm{mg}$ F/L de flúor durante o período de desenvolvimento dos dentes pode resultar em fluorose dentária, nas suas formas mais leves. As crianças que estavam expostas a $1 \mathrm{mg}$ F/L de flúor apresentaram menor risco de cárie dentária em relação às que viviam em regiões subfluoretadas (JACKSON et al. $\left.{ }^{76}, 1999\right)$.

Mediante uma interrupção de 11 meses na fluoretação de água de Durham, Carolina do Norte, EUA, passando de $1 \mathrm{mg}$ F/L de flúor, para zero ou concentrações insignificantes, entre setembro de 1990 e agosto de 1991, por razões técnicas, pesquisou-se o possível impacto da interrupção da fluoretação no desenvolvimento de cárie dentária e fluorose, e ainda, as idades nas quais a fluoretação da água tem seu máximo efeito. Os grupos de estudo foram estabelecidos de acordo com a idade das crianças no momento da interrupção da fluoretação, variando do nascimento aos 3 anos para cárie dentária, e do nascimento até 5 anos, para fluorose. Os resultados demonstraram que a cárie estava associada ao nível educacional das mães. Não foi observado efeito da fluoretação na cárie, em nenhum dos grupos etários. No entanto, a prevalência de fluorose foi de $44 \%$, sendo que a prevalência constatada nos grupos de 1, 2, 3, 4 e 5 anos foi 39,8\%, 32,3\%, $33,0 \%, 62,3 \%$ e $57,1 \%$, respectivamente, diferenças estas estatisticamente significantes. Apesar da interrupção causar pequenos efeitos na cárie dentária, a fluorose é mais sensível a pequenas alterações no nível de flúor na água, principalmente nas idades de 1 a 3 anos, em relação às idades de 4 e 5 anos (BURT; KEELS; HELLER $\left.{ }^{31}, 2000\right)$. 
Em 1955, mais de 15\% da população americana tinha acesso à água fluoretada. Em 1965 aumentou em 30\%, e em 1970, por volta de 49\%. A partir de 1975, o processo tornou-se mais lento. Em 1996, aproximadamente 10.000 comunidades nos EUA estavam ajustando a concentração de flúor na água e outras 3.700 possuíam água naturalmente fluoretada em concentração adequada. As estimativas mais recentes indicaram que 144,2 milhões de pessoas (56\% da população americana) recebem água fluoretada na concentração adequada (de 0,7 a 1,2 mg/L, dependendo da temperatura média da máxima anual da região), sendo que $62 \%$ da população vive em região com central de tratamento de água. Um dos fatores que explicam o declínio dos benefícios da fluoretação da água é o efeito halo e outro é o uso de vários produtos com flúor como gel, vernizes, bochechos e suplementos fluoretados. Nos Estados Unidos, a fluoretação tem encontrado dificuldades, tanto por resistência na sua adoção quanto por problemas econômicos e políticos. Um dos entraves para o sucesso na fluoretação da água no futuro é o fato da sociedade, alguns cientistas e governantes não verem mais a cárie como um grande problema de saúde pública, além da falta de conhecimento da sociedade sobre os benefícios da fluoretação, do aumento da prevalência de fluorose dentária e os conceitos mal fundamentados sobre poluição ambiental. Existe ainda um problema de ordem técnica, o controle e monitoramento do equipamento de fluoretação, fazendo com que em algumas regiões a concentração fique abaixo do ideal. Portanto, há necessidade de educação, treinamento e programas de incentivo ao pessoal envolvido neste trabalho (HOROWITZ $\left.{ }^{74}, 1996\right)$. 
Embora seja considerado o método mais barato e efetivo de prevenção de cárie, aproximadamente 46 mil centrais de abastecimento de água, servindo mais de 1/3 da população americana, ainda não fluoretavam suas águas em 1996. Apesar da impressão de haver progressos na fluoretação da água, a diferença entre a população que recebe água fluoretada e não, se mostra significante; ela manteve-se a mesma desde 1980. O Serviço de Saúde Pública estabeleceu as metas a serem alcançadas nos anos de 1980 e 1990, sendo que a meta a ser alcançada com a fluoretação foi a de aumentar em 75\%, no mínimo, a proporção de pessoas atendidas pelo Sistema de Abastecimento de Água, com níveis ótimos de flúor (baseline: 62\% em 1989). A estratégia do CDC definiu a natureza do problema através da busca deste objetivo e, uma vez definidas as prioridades do CDC, estabeleceram-se 6 pontos principais para ação: 1) Análise, avaliação e vigilância; 2) Consulta; 3) Esforços estaduais e regionais; 4) Educação e envolvimento profissional; 5) Educação da população; e 6) Monitoramento dos níveis de flúor. O detalhamento e a conscientização da importância de cada um destes pontos é fundamental para se alcançar à meta (REEVES $\left.{ }^{115}, 1996\right)$.

Na República dA IRLANDA, a sugestão de fluoretar a água de abastecimento foi dada pelo Dr. Trendley Dean, enquanto participava do Encontro Científico Anual do Royal College of Surgeons of Ireland, em Dublin, na metade da década de 1950. Em 1958 ficou determinada a concentração de 1,0 mg/L como sendo a mais adequada. A partir de 1964 a água passou a ser fluoretada, em Dublin (O'MULLANE et al. ${ }^{104}$, 1996). Durante os anos de 1961 e 1963 um estudo foi conduzido para verificar a 
prevalência de cárie antes da adoção da fluoretação da água e determinar o baseline, bem como monitorar a efetividade do método que estava para ser adotado. A pesquisa foi realizada com escolares de 5, 8, 12 e 15 anos. Após 10 anos, a maioria das comunidades urbanas já recebia o benefício e, até 1996, 67\% da população da Irlanda recebia água fluoretada (O’MULLANE et al. $\left.{ }^{104}, 1996\right)$. Estudos posteriores demonstraram o declínio na prevalência de cárie tanto na população residente em áreas não fluoretadas como fluoretadas, sendo que a redução foi mais significativa nestas últimas. Em 1984, 20 anos após o início da fluoretação, houve aumento na porcentagem de crianças livres de cárie, tanto nas comunidades com água fluoretada como nas que não possuíam este benefício. Nos anos de 1992, 1993 e 1995 foram realizados levantamentos para verificar o CPO-D nas comunidades fluoretadas e não fluoretadas, bem como estabelecer uma comparação com os dados de 1961-1963 (baseline). A redução no CPO-D e incremento de indivíduos livres de cárie foram constatados em todas as idades examinadas (5, 8 e 12 anos de idade). Enquanto que nos exames realizados em adultos com idades entre 16 e mais de 65 anos, observou-se que os residentes em áreas fluoretadas apresentaram CPO-D menor, maior número de dentes presentes na cavidade bucal, maior porcentagem de indivíduos com mais de 20 dentes, menor porcentagem de edentados e menos casos de exposição radicular. Os resultados indicam que, após 30 anos de fluoretação na Irlanda, houve declínio na prevalência de cárie nas crianças e uma maior conservação de dentes naturais nos adultos. Com o passar dos anos, a efetividade do método "diminuiu" e as condições bucais dos moradores das comunidades não fluoretadas passaram a se assemelhar às da população 
com água fluoretada. Esta constatação é esperada uma vez que a força máxima do método só é alcançada quando existe alta prevalência da doença, e como houve diminuição do CPO-D, aparentemente a efetividade do método diminuiu. Este fato pode ser explicado, por exemplo, pelo consumo de refrigerantes fabricados em regiões fluoretadas pela população que reside nas comunidades não fluoretadas, e pessoas de comunidades não fluoretadas que ocasionalmente passam as férias ou finais de semana em áreas fluoretadas. Outro fator importante foi a fluoretação dos dentifrícios a partir de 1970 (O’MULLANE et al. $\left.{ }^{104}, 1996\right)$.

Apesar de ter ocorrido uma redução significativa na prevalência de cárie na Irlanda ao longo dos anos de fluoretação, a cárie continuava a representar um sério problema no país, principalmente nas comunidades que ainda não são fluoretadas. Nos adultos, os resultados também se mostraram favoráveis, mas como estava havendo uma maior conservação de dentes naturais na boca, acredita-se que os benefícios do flúor na redução do risco de cárie radicular teriam um impacto maior no futuro (O’MULLANE et al. $\left.{ }^{104}, 1996\right)$.

Na Nova Zelândia, assim como em outros países, também se observou um declínio substancial na prevalência de cárie e um aumento no uso de flúor. Os níveis de cárie diminuíram tanto nas comunidades fluoretadas como nas não fluoretadas, embora a diminuição tenha sido $20 \%$ maior nas fluoretadas. Esta diferença "pequena" entre as comunidades se deve à variedade de fontes de obtenção de flúor (CUTRESS et al. ${ }^{51}$, 1996).

No REINo UnIDo, em Huddersfield, após 19 anos de fluoretação da água de abastecimento público, determinou-se a interrupção em 31 de 
outubro de 1989. Para avaliar os benefícios da fluoretação da água sobre a saúde bucal das crianças de 3 anos de idade, no Reino Unido, foi proposto comparar a prevalência de cárie dentária entre crianças de 3 anos de idade que moravam na região fluoretada de Huddersfield (1 mg/L) com a prevalência de uma região não fluoretada, Dewsbury $(<0,3 \mathrm{mg} / \mathrm{L})$. Além disto, comparou-se a prevalência de fluorose dentária nestas duas regiões. Os resultados obtidos apontaram um ceod médio de 0,3 em Huddersfield e de 0,74 em Dewsbury. A porcentagem de crianças que tiveram experiência de cárie foi, significativamente, mais baixa em Huddersfield. A diferença no ceod deu-se em 59\% e, apesar da diferença ser de apenas 0,4 dente, ainda é importante em termos de saúde pública já que somente uma criança de Huddersfield apresentou experiência de dor de dente, contra oito em Dewsbury. Os resultados sugerem que a interrupção da fluoretação da água de Huddersfield fosse suspensa o mais breve possível (BOOTH et al. ${ }^{16}$, 1991).

NA SuíçA, realizou-se um levantamento dos resultados mais importantes das avaliações feitas sobre os benefícios da água de abastecimento público fluoretada em Basel, publicados em periódicos científicos ou disponíveis em documentos de instituições provedoras de tratamento dentário. Basel era abastecida com água fluoretada desde 1962 com a concentração de flúor de $1 \mathrm{mg} / \mathrm{L}$, exceto em julho e agosto, quando se adiciona 0,8 mg/L à água, com uma média anual de 0,96 mg/L de flúor. $A$ prevalência de cárie em escolares apresentou um declínio, até 1977, correlacionado a fluoretação da água. No entanto, a partir de 1980, outros fatores passaram a interagir com a fluoretação e foram relacionados à 
manutenção do declínio da cárie dentária. Os resultados destas avaliações indicaram que a prevalência de cárie em Basel foi, tão baixa quanto naquelas outras regiões da Suíça onde existiam programas de educação em saúde bucal ou programas amplos de fluoretação do sal implementados por muitos anos. A fluoretação da água tem resultado no benefício esperado, continua a ser necessária e o desenvolvimento de uma política recente sugere que a fluoretação da água continuará existindo lado a lado à fluoretação do sal, a qual é realizada fora da região de Basel pelas cidades vizinhas e países com a qual fazem fronteira (MARTHALLER $\left.{ }^{88}, 1996\right)$. 


\subsection{A fluoretação da Água de Abastecimento Público no BRASIL}

Em 1950, quando já estavam cientificamente confirmados os resultados dos primeiros estudos de fluoretação controlada da água, é que a ADA passa a recomendar a fluoretação das águas de abastecimento público. A Organização Mundial da Saúde (OMS), a Organização Panamericana da Saúde (OPAS), o Ministério da Saúde (MS) e todas as entidades nacionais representativas da área odontológica no Brasil recomendam a fluoretação das águas de abastecimento público nos locais onde há indicação técnica para aplicar a medida (CHAVES ${ }^{43}, 1986$; BRASIL $\left.^{24}, 1999\right)$.

No $\mathrm{X}$ Congresso Brasileiro de Higiene, realizado em Belo Horizonte, Minas Gerais, em outubro de 1952, pela primeira vez recomendou-se oficialmente, no Brasil, a adição de flúor à água de abastecimento público (NARVAI $\left.{ }^{98}, 2001\right)$. Anteriormente a esta data, Rossi e Oliveira, em 1947, ressaltaram que:

"em São Paulo já foi verificada a pequena quantidade de flúor nas águas de abastecimento e foi também proposto [grifo do autor] o acréscimo de quantidade que perfaçam a normalidade. Infelizmente, verificamos nenhuma providência das autoridades sobre o assunto e nossas águas continuam apresentando a insignificante proporção de 0,2 a 0,4 ppm de $F($...) proporemos a dosagem e controle das quantidades de F não só em São Paulo, mas em todo Brasil." (ROSSI; OLIVEIRA, 1954 apud NARVAI ${ }^{98}$, 2001). 
Após oito anos de estudos realizados em Grand Rapids, a Fundação Serviços de Saúde Pública (FSESP), do Ministério da Saúde, implantou em 31 de outubro de 1953, o primeiro sistema de fluoretação de águas no Brasil. O primeiro município brasileiro a adicionar flúor nas águas de abastecimento público foi Baixo Guandu, no Espírito Santo. O teor de flúor natural da água era de 0,15 mg/L e teor ótimo final, foi estabelecido em 0,8 mg F/L (KOZLOWSKI; PEREIRA ${ }^{77}$, 2003). A implantação da fluoretação ocorreu um ano após a recomendação da mesma no X Congresso Brasileiro de Higiene (CHAVES et al. ${ }^{42}$, 1953). Mantido como piloto, foi o pioneiro a comprovar os benefícios obtidos em outros países na redução da cárie dentária. O índice CPO-D, das crianças na faixa etária de 6 a 12 anos de idade, em 1967, após 14 anos de iniciada a fluoretação das águas, apresentou uma redução de 67\% (KOZLOWSKI; PEREIRA ${ }^{77}$, 2003).

Vários outros municípios brasileiros, posteriormente, passaram a adotar a fluoretação das águas de abastecimento público. No Estado de São Paulo, em 1956, Marília iniciou a fluoretação; em 1961, Campinas; em 1971, Piracicaba e Barretos; em 1975, Bauru e Santos; em 1980, Paulínia; em 1981, Birigui; em 1985, São Paulo, capital do Estado de São Paulo. A fluoretação da água do município de São Paulo foi implantada pela Companhia de Saneamento Básico do Estado de São Paulo (SABESP). O teor adequado de flúor para o município foi definido em 0,7 mg/L, com uma expectativa de redução na incidência de cárie de 50\%. Esta meta de redução foi estabelecida levando-se em consideração não submeter a população a nenhum risco de saúde; estipulando ainda que uma variação de 0,1 mg F/L para mais ou para menos em relação à concentração ótima de 
0,7 mg F/L seria considerada aceitável (0,6-0,8 mg/L). A primeira capital de Estado, a fluoretar suas águas foi Curitiba, no Paraná, em 1958 (AMARANTE; JITOMIRSKI; AMARANTE ${ }^{1}, \quad$ 1993; NARVAI ${ }^{98}, \quad 2001 ;$ KOZLOWSKI; PEREIRA $\left.{ }^{77}, 2003\right)$.

A partir de 1974 , a fluoretação das águas de abastecimento público passa a ser obrigatória no Brasil, através da lei federal $n^{0} 6.050$, de 24 de maio de 1974, que dispõe sobre a fluoretação da água em sistemas públicos de abastecimento, sendo devidamente regulamentada pelo Decreto Federal $\mathrm{n}^{\mathrm{0}}$ 76.872, de 22 de dezembro de 1975 (BRASIL ${ }^{17}, 1974$; BRASIL $\left.^{18}, 1975\right)$.

Diversas medidas legais e ações oficiais têm sustentado a adoção da fluoretação como a principal medida de saúde pública na área odontológica a nível nacional. Após a lei 6.050, de 1975, foi firmada em 1983 a Exposição de Motivos 216, da Presidência da República instituindo o Programa Nacional de Fluoretação da Água de Abastecimento Público com recursos do FINSOCIAL (US\$6,7 milhões no $1^{\circ}$ ano). Até o ano de 1989, foram disponibilizados recursos para a expansão do programa. O Ministério da Saúde, em 1989, ao estabelecer o Programa Nacional de Saúde Bucal (Portaria 613/GM), declarou que para o controle da cárie dentária há necessidade de fazer concomitantemente uso tópico e sistêmico (ingestão), de fluoretos em dosagens adequadas. Ainda segundo o Ministério, a fluoretação da água de abastecimento público é o método de ingestão indicado. O Programa Nacional de Prevenção da Cárie Dentária, também definiu a fluoretação como método de escolha para prevenção em massa da 
cárie, considerando que seus efeitos têm sido sistematicamente comprovados (PINTO $\left.{ }^{110}, 1993\right)$.

A expanção da fluoretação deu-se de forma gradual, sendo que em 1972 a população beneficiada era de apenas 3,3 milhões de habitantes; em 1982, 25,7 milhões; em 1989, 60,4 milhões e em 1996, 68 milhões (PINTO $^{110}$, 1993; BRASIL ${ }^{22}$, 1996; NARVAI; FRAZÃO; CASTELLANOS ${ }^{96}$, 1999).

Segundo o Ministério da Saúde Brasileiro :

"estima-se que aproximadamente 65 milhões de brasileiros estão sendo atualmente beneficiados pela agregação de flúor ao tratamento da água com resultados comprovados de eficiência do método" (MINISTÉRIO DA SAÚDE, 1999).

Os benefícios desta medida preventiva já vêm sendo observados nos últimos anos, como relata o Parecer Técnico elaborado pelo Comitê Técnico-Científico de Saúde Bucal do Ministério da Saúde, haja visto os resultados observados no Levantamento Epidemiológico em Saúde Bucal Cárie Dental, realizado pelo Ministério da Saúde em 1996, quando se verificou uma redução do índice CPO-D aos 12 anos da ordem de 54\% (BRASIL ${ }^{22}$, 1996). Segundo NARVAI, FRAZÃO e CASTELLANOS, em 1999, através da análise dos dados de estudos que utilizaram como instrumento de medida de cárie, o índice CPO-D, além de informações disponíveis no site do Ministério da Saúde na Internet a análise, verificou-se uma significativa redução nos valores do índice CPO-D no período 1980-1996. Para a idade de 12 anos, o índice que em 1980 era de 7,25 ("prevalência muito alta"), apresentou uma consistente tendência de queda ao longo do 
período, atingindo o valor de 3,06 ("prevalência moderada"), em 1996. Observou-se também uma reducão bastante significativa para as idades entre 7 e 11 anos (TABELA 5). Entre 1980 e 1996 a redução nos valores do índice para a idade de 12 anos foi cerca de $57,8 \%$. A prevalência para a idade de 12 anos mostra diferenças importantes de acordo com as macrorregiões do Brasil (FIGURA 1) (NARVAI; FRAZÃO; CASTELLANOS ${ }^{96}$, 1999).

TABELA 5 - Índice CPO-D médio segundo a idade em escolares. Brasil, 1980, 1986, 1993, 1996

\begin{tabular}{ccccc}
\hline Idade & $\begin{array}{c}\text { CPO-D } \\
\mathbf{1 9 8 0}\end{array}$ & $\begin{array}{c}\text { CPO-D } \\
\mathbf{1 9 8 6}\end{array}$ & $\begin{array}{c}\text { CPO-D } \\
\mathbf{1 9 9 3}\end{array}$ & $\begin{array}{c}\text { CPO-D } \\
\mathbf{1 9 9 6}\end{array}$ \\
\hline 7 & 2,56 & 2,24 & 1,27 & 0,7 \\
8 & 3,39 & 2,84 & 1,83 & 1,16 \\
9 & 3,88 & 3,61 & 2,34 & 1,53 \\
10 & 4,74 & 4,56 & 2,98 & 1,88 \\
11 & 5,92 & 5,8 & 3,71 & 2,39 \\
12 & 7,25 & 6,66 & 4,84 & 3,06 \\
\hline
\end{tabular}

Fonte: Narvai; Frazão; Castellanos ${ }^{96}, 1999$.

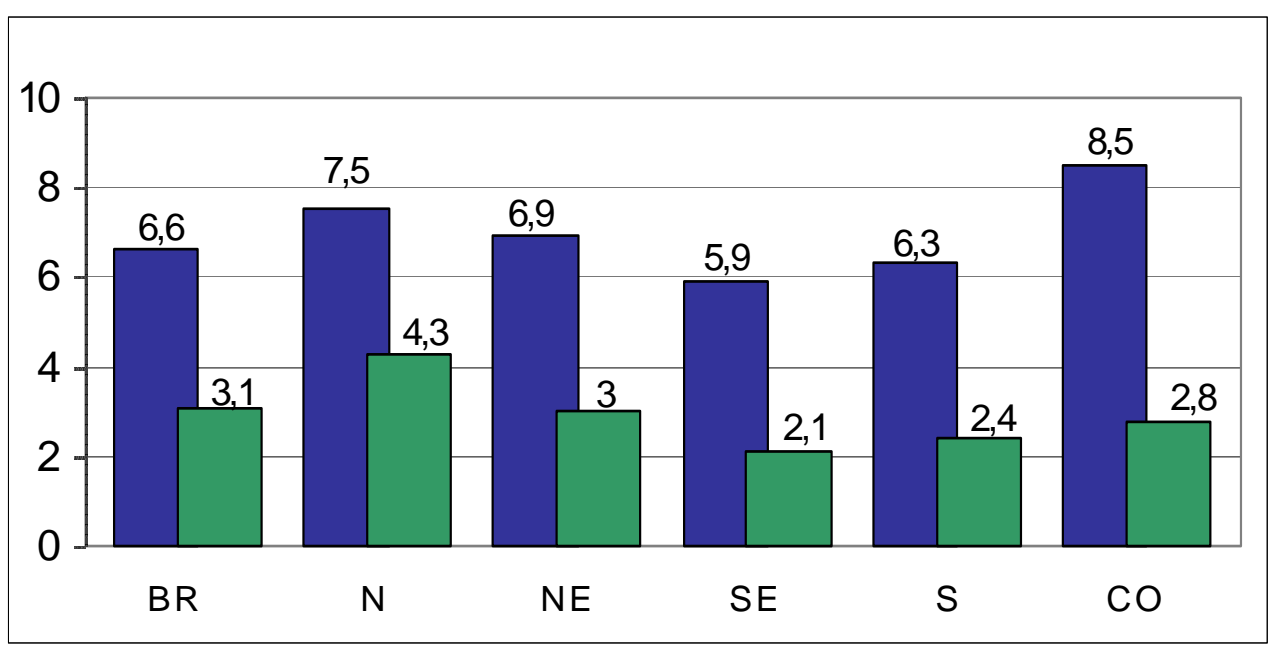

Fonte: Narvai; Frazão; Castellanos ${ }^{96}, 1999$, Rev. Odontologia e Sociedade, p.26-7.

FIGURA 1 - Índice CPO-D médio aos 12 anos de idade em 1986 e 1996, segundo macrorregiões brasileiras 
Os dados relativos à fluoretação da água de abastecimento público no Brasil, disponívies no Ministério da Saúde permitem entender a seu alcance territorial no país (BRASIL ${ }^{22}, 1996$ ). Com o Levantamento da Situação da Fluoretação de Águas de Abastecimento Público, realizado pelo Ministério da Saúde no ano de 1996 nas 26 capitais e no Distrito Federal, a Área Técnica de Saúde Bucal teve como objetivo maior apresentar uma visão mais aproximada do quadro atual da fluoretação da água de abastecimento público do país (TABELAS 6, 7, 8, 9, 10 e 11). 
TABELA 6 - Percentual da população beneficiada com água fluoretada em relação à população total do país, por Estado. Brasil, 1996

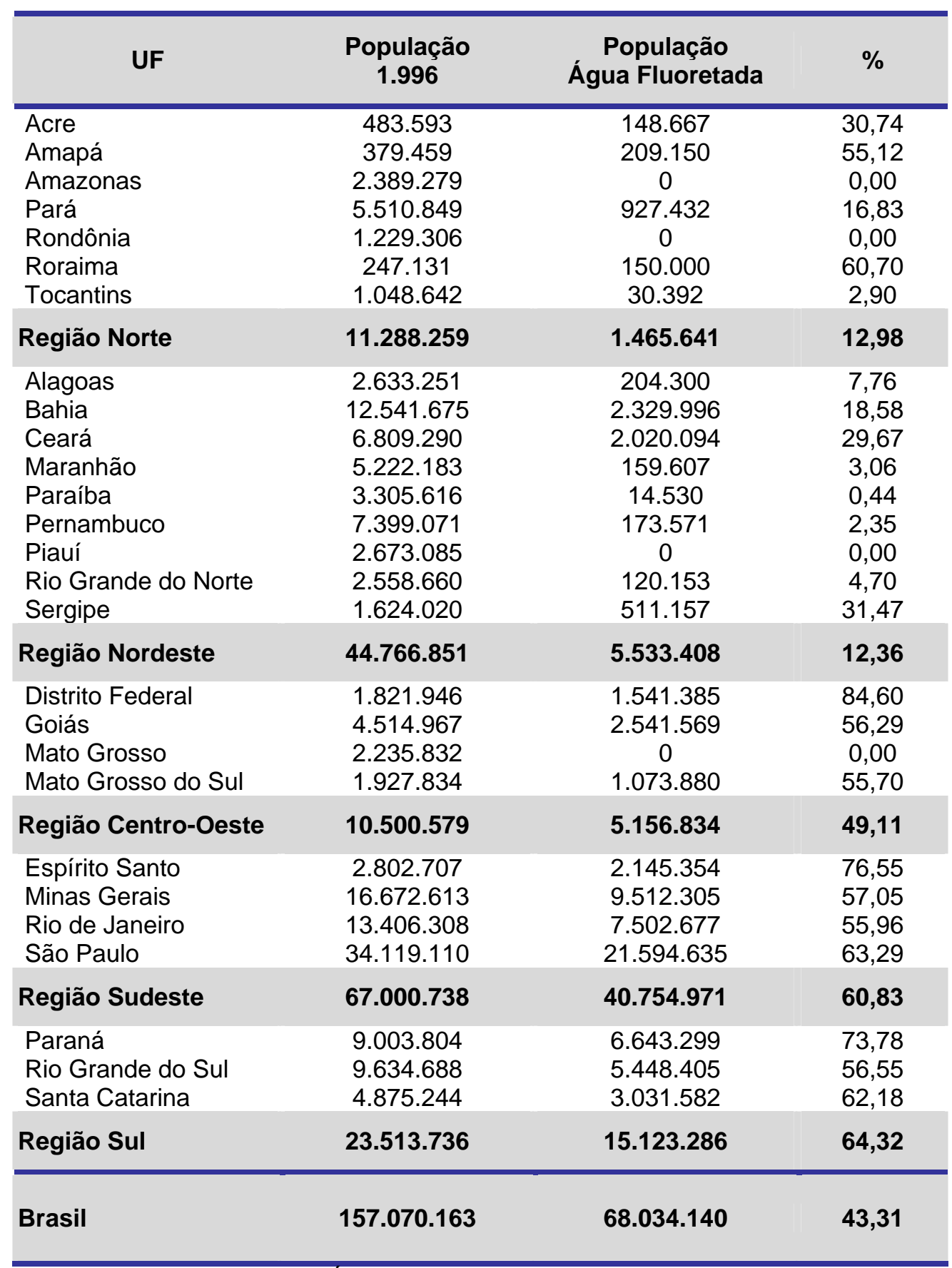

Fonte: Ministério da Saúde. Área Técnica de Saúde Bucal, 1996. 
TABELA 7 - Percentual da população beneficiada com água fluoretada em relação à população com água tratada, por Estado. Brasil, 1996

\begin{tabular}{|c|c|c|c|c|}
\hline UF & $\begin{array}{c}\text { População } \\
1.996\end{array}$ & $\begin{array}{l}\text { População } \\
\text { Água Tratada }\end{array}$ & $\begin{array}{c}\text { População } \\
\text { Água Fluoretada }\end{array}$ & $\%$ \\
\hline Acre & 483.593 & 214.333 & 148.667 & 69,36 \\
\hline Amapá & 379.459 & 230.570 & 209.150 & 90,71 \\
\hline Amazonas & 2.389 .279 & 1.669 .988 & 0 & 0,00 \\
\hline Pará & 5.510 .849 & 1.417 .420 & 927.432 & 65,43 \\
\hline Rondônia & 1.229 .306 & 463.600 & 0 & 0,00 \\
\hline Roraima & 247.131 & 238.220 & 150.000 & 62,97 \\
\hline Tocantins & 1.048 .642 & 486.211 & 30.392 & 6,25 \\
\hline Região Norte & 11.288.259 & 4.720 .342 & 1.465 .641 & 31,05 \\
\hline Alagoas & 2.633 .251 & 1.615 .619 & 204.300 & 12,65 \\
\hline Bahia & 12.541 .675 & 5.880 .402 & 2.329 .996 & 39,62 \\
\hline Ceará & 6.809 .290 & 2.969 .119 & 2.020 .094 & 68,04 \\
\hline Maranhão & 5.222 .183 & 1.399 .777 & 159.607 & 11,40 \\
\hline Paraíba & 3.305 .616 & 1.983 .192 & 14.530 & 0,73 \\
\hline Pernambuco & 7.399 .071 & 4.748 .780 & 173.571 & 3,66 \\
\hline Piauí & 2.673 .085 & 1.117 .772 & 0 & 0,00 \\
\hline Rio Grande do Norte & 2.558 .660 & 1.534 .728 & 120.153 & 7,83 \\
\hline Sergipe & 1.624 .020 & 1.367 .488 & 511.157 & 37,38 \\
\hline Região Nordeste & 44.766 .851 & 22.616.877 & 5.533 .408 & 24,47 \\
\hline Distrito Federal & 1.821 .946 & 1.541 .385 & 1.541 .385 & 100,00 \\
\hline Goiás & 4.514 .967 & 2.968 .016 & 2.541 .569 & 85,63 \\
\hline Mato Grosso & 2.235 .832 & 1.446 .501 & 0 & 0,00 \\
\hline Mato Grosso do Sul & 1.927 .834 & 1.639 .668 & 1.073 .880 & 65,49 \\
\hline Região Centro-Oeste & 10.500 .579 & 595.570 & 5.156 .834 & 67,89 \\
\hline Espírito Santo & 2.802 .707 & 2.273 .797 & 2.145 .354 & 94,35 \\
\hline Minas Gerais & 16.672 .613 & 10.244 .454 & 9.512 .305 & 92,85 \\
\hline Rio de Janeiro & 13.406 .308 & 9.529 .562 & 7.502 .677 & 78,73 \\
\hline São Paulo & 34.119 .110 & 22.289 .872 & 21.594 .635 & 96,88 \\
\hline Região Sudeste & 67.000 .738 & 44.337 .685 & 40.754.971 & 91,92 \\
\hline Paraná & 9.003 .804 & 6.997 .255 & 6.643 .299 & 94,94 \\
\hline Rio Grande do Sul & 9.634 .688 & 5989980 & 5.448 .405 & 90,96 \\
\hline Santa Catarina & 4.875 .244 & 3257938 & 3.031 .582 & 93,05 \\
\hline Região Sul & 23.513.736 & 16.245 .173 & 15.123 .286 & 93,09 \\
\hline Brasil & 157.070.163 & 95.515 .647 & 68.034 .140 & 71,23 \\
\hline
\end{tabular}

Fonte: Ministério da Saúde. Área Técnica de Saúde Bucal, 1996. 
TABELA 8 - Percentual da população beneficiada com água fluoretada em relação à população total das capitais. Brasil,1996

\begin{tabular}{|c|c|c|c|}
\hline CAPITAL & $\begin{array}{c}\text { População Total } \\
1.996\end{array}$ & $\begin{array}{l}\text { População } \\
\text { Água Fluoretada }\end{array}$ & $\%$ \\
\hline Rio Branco & 203.891 & 148.667 & 72,91 \\
\hline Macapá & 189.376 & 169.100 & 89,29 \\
\hline Manaus & 1.128 .175 & 0 & 0,00 \\
\hline Belém & 1.356 .285 & 905.002 & 66,73 \\
\hline Porto Velho & 320.148 & 0 & 0,00 \\
\hline Boa Vista & 173.981 & 150.000 & 86,22 \\
\hline Palmas & 49.363 & 19.203 & 38,90 \\
\hline Maceió & 688.856 & 0 & 0,00 \\
\hline Salvador & 2.239 .226 & 2.017 .014 & 90,08 \\
\hline Fortaleza & 1.893 .313 & 1.644 .971 & 86,88 \\
\hline São Luís & 758.982 & 0 & 0,00 \\
\hline João Pessoa & 536.641 & 0 & 0,00 \\
\hline Recife & 1.341 .910 & 0 & 0,00 \\
\hline Teresina & 653.094 & 0 & 0,00 \\
\hline Natal & 658.298 & 0 & 0,00 \\
\hline Aracaju & 435.447 & 435.447 & 100,00 \\
\hline Brasília & 256.500 & 256.500 & 100,00 \\
\hline Goiânia & 1.136 .903 & 1.007 .677 & 88,63 \\
\hline Cuiabá & 462.739 & 0 & 0,00 \\
\hline Campo Grande & 585.100 & 450.527 & 77,00 \\
\hline Vitória & 310.419 & 290.796 & 93,68 \\
\hline Belo Horizonte & 2.106 .817 & 2.049 .012 & 97,26 \\
\hline Rio de Janeiro & 5.645 .166 & 4.734 .149 & 83,86 \\
\hline São Paulo & 10.142 .504 & 9.211 .000 & 90,82 \\
\hline Curitiba & 1.384 .163 & 1.384 .163 & 100,00 \\
\hline Porto Alegre & 1.308 .538 & 1.282 .367 & 98,00 \\
\hline Florianópolis & 274.774 & 199.458 & 72,59 \\
\hline Brasil - Capitais & 36.240 .609 & 26.355 .053 & 72,72 \\
\hline
\end{tabular}

Fonte: Ministério da Saúde. Área Técnica de Saúde Bucal, 1996. 
TABELA 9 - Percentual da população beneficiada com água fluoretada em relação à população com água tratada e início da fluoretação, nas capitais. Brasil, 1996

\begin{tabular}{|c|c|c|c|c|}
\hline Capital & $\begin{array}{l}\text { População } \\
\text { Água Tratada }\end{array}$ & $\begin{array}{l}\text { População } \\
\text { Água Fluoretada }\end{array}$ & $\%$ & $\begin{array}{c}\text { Início } \\
\text { Fluoretação }\end{array}$ \\
\hline Rio Branco & 162.917 & 148.667 & 91,25 & 1988 \\
\hline Macapá & 189.376 & 169.100 & 89,29 & 1974 \\
\hline Manaus & 1.072 .555 & 0 & 0,00 & - \\
\hline Belém & 1.100 .185 & 905.002 & 82,26 & 1985 \\
\hline Porto Velho & 149.421 & 0 & 0,00 & - \\
\hline Boa Vista & 150.000 & 150.000 & 100,00 & 1977 \\
\hline Palmas & 44.660 & 19.203 & 43,00 & 1994 \\
\hline Maceió & 612.242 & 0 & 0,00 & - \\
\hline Salvador & 2.017 .014 & 2.017 .014 & 100,00 & 1996 \\
\hline Fortaleza & 1.644 .971 & 1.644 .971 & 100,00 & 1989 \\
\hline São Luís & 758.982 & 0 & 0,00 & - \\
\hline João Pessoa & 532.623 & 0 & 0,00 & - \\
\hline Recife & 1.308 .744 & 0 & 0,00 & - \\
\hline Teresina & 646.563 & 0 & 0,00 & - \\
\hline Natal & 588.723 & 0 & 0,00 & - \\
\hline Aracaju & 435.447 & 435.447 & 100,00 & 1996 \\
\hline Brasília & 256.500 & 256.500 & 100,00 & 1960 \\
\hline Goiânia & 1.007 .677 & 1.007 .677 & 100,00 & 1985 \\
\hline Cuiabá & 462.739 & 0 & 0,00 & - \\
\hline Campo Grande & 579.459 & 450.527 & 77,75 & 1987 \\
\hline Vitória & 290.796 & 290.796 & 100,00 & 1982 \\
\hline Belo Horizonte & 2.049 .012 & 2.049 .012 & 100,00 & 1975 \\
\hline Rio de Janeiro & 5.260 .166 & 4.734.149 & 90,00 & 1980 \\
\hline São Paulo & 9.211 .000 & 9.211 .000 & 100,00 & 1985 \\
\hline Curitiba & 1.384 .163 & 1.384 .163 & 100,00 & 1959 \\
\hline Porto Alegre & 1.282 .367 & 1.282 .367 & 100,00 & 1991 \\
\hline Florianópolis & 199.458 & 199.458 & 100,00 & 1982 \\
\hline Brasil - Capitais & 33.397 .760 & 26.355 .053 & 78,91 & - \\
\hline
\end{tabular}

Fonte: Ministério da Saúde. Área Técnica de Saúde Bucal, 1996. 
TABELA 10 - Percentual de municípios beneficiados com água fluoretada em relação ao total de municípios do país, por Estado. Brasil 1996

\begin{tabular}{|c|c|c|c|}
\hline UF & $\begin{array}{c}\text { Total } \\
\text { Municípios }\end{array}$ & $\begin{array}{l}\text { Municípios } \\
\text { Água Fluoretada }\end{array}$ & $\%$ \\
\hline Acre & 22 & 1 & 4,55 \\
\hline Amapá & 15 & 2 & 13,33 \\
\hline Amazonas & 62 & 0 & 0,00 \\
\hline Pará & 128 & 2 & 1,56 \\
\hline Rondônia & 40 & 0 & 0,00 \\
\hline Roraima & 8 & 1 & 12,50 \\
\hline Tocantins & 123 & 2 & 1,63 \\
\hline Região Norte & 398 & 8 & 2,01 \\
\hline Alagoas & 100 & 10 & 10,00 \\
\hline Bahia & 415 & 10 & 2,41 \\
\hline Ceará & 184 & 16 & 8,70 \\
\hline Maranhão & 136 & 5 & 3,68 \\
\hline Paraíba & 171 & 2 & 1,17 \\
\hline Pernambuco & 178 & 8 & 4,49 \\
\hline Piauí & 148 & 0 & 0,00 \\
\hline Rio Grande do Norte & 152 & 5 & 3,29 \\
\hline Sergipe & 75 & 3 & 4,00 \\
\hline Região Nordeste & 1.559 & 59 & 3,78 \\
\hline Distrito Federal & 15 & 13 & 86,67 \\
\hline Goiás & 234 & 96 & 41,03 \\
\hline Mato Grosso & 117 & 0 & 0,00 \\
\hline Mato Grosso do Sul & 77 & 28 & 36,36 \\
\hline Região Centro-Oeste & 443 & 137 & 30,93 \\
\hline Espírito Santo & 71 & 66 & 92,96 \\
\hline Minas Gerais & 756 & 401 & 53,04 \\
\hline Rio de Janeiro & 81 & 12 & 14,81 \\
\hline São Paulo & 625 & 365 & 58,40 \\
\hline Região Sudeste & 1.533 & 844 & 55,06 \\
\hline Paraná & 371 & 319 & 85,98 \\
\hline Rio Grande do Sul & 427 & 146 & 34,19 \\
\hline Santa Catarina & 260 & 150 & 57,69 \\
\hline Região Sul & 1.058 & 615 & 58,13 \\
\hline Brasil & 4.991 & 1.663 & 33,32 \\
\hline
\end{tabular}

Fonte: Ministério da Saúde. Área Técnica de Saúde Bucal, 1996. 
TABELA 11 - Percentual de municípios beneficiados com água fluoretada em relação ao total de municípios com água tratada, por Estado. Brasil, 1996

\begin{tabular}{|c|c|c|c|}
\hline UF & $\begin{array}{l}\text { Municípios } \\
\text { Água Tratada }\end{array}$ & $\begin{array}{l}\text { Municípios } \\
\text { Água Fluoretada }\end{array}$ & $\%$ \\
\hline $\begin{array}{l}\text { Acre } \\
\text { Amapá } \\
\text { Amazonas } \\
\text { Pará } \\
\text { Rondônia } \\
\text { Roraima } \\
\text { Tocantins }\end{array}$ & $\begin{array}{c}14 \\
11 \\
58 \\
22 \\
30 \\
8 \\
82\end{array}$ & $\begin{array}{l}1 \\
2 \\
0 \\
2 \\
0 \\
1 \\
2\end{array}$ & $\begin{array}{c}7,14 \\
18,18 \\
0,00 \\
9,09 \\
0,00 \\
12,50 \\
2,44\end{array}$ \\
\hline Região Norte & 225 & 8 & 3,56 \\
\hline $\begin{array}{l}\text { Alagoas } \\
\text { Bahia } \\
\text { Ceará } \\
\text { Maranhão } \\
\text { Paraíba } \\
\text { Pernambuco } \\
\text { Piauí } \\
\text { Rio Grande do Norte } \\
\text { Sergipe }\end{array}$ & $\begin{array}{c}100 \\
415 \\
144 \\
112 \\
171 \\
169 \\
13 \\
135 \\
75\end{array}$ & $\begin{array}{l}10 \\
10 \\
16 \\
5 \\
2 \\
8 \\
0 \\
5 \\
3\end{array}$ & $\begin{array}{c}10,00 \\
2,41 \\
11,11 \\
4,46 \\
1,17 \\
4,73 \\
0,00 \\
3,70 \\
4,00\end{array}$ \\
\hline Região Nordeste & 1.334 & 59 & 4,42 \\
\hline $\begin{array}{l}\text { Distrito Federal } \\
\text { Goiás } \\
\text { Mato Grosso } \\
\text { Mato Grosso do Sul }\end{array}$ & $\begin{array}{c}13 \\
211 \\
92 \\
77\end{array}$ & $\begin{array}{c}13 \\
96 \\
0 \\
28\end{array}$ & $\begin{array}{c}100,0 \\
45,50 \\
0,00 \\
36,36\end{array}$ \\
\hline Região Centro-Oeste & 393 & 137 & 34,86 \\
\hline $\begin{array}{l}\text { Espírito Santo } \\
\text { Minas Gerais } \\
\text { Rio de Janeiro } \\
\text { São Paulo }\end{array}$ & $\begin{array}{c}71 \\
504 \\
65 \\
395\end{array}$ & $\begin{array}{c}66 \\
401 \\
12 \\
365\end{array}$ & $\begin{array}{l}92,96 \\
79,56 \\
18,46 \\
92,41\end{array}$ \\
\hline Região Sudeste & 1.035 & 844 & 81,55 \\
\hline $\begin{array}{l}\text { Paraná } \\
\text { Rio Grande do Sul } \\
\text { Santa Catarina }\end{array}$ & $\begin{array}{l}371 \\
274 \\
223\end{array}$ & $\begin{array}{l}319 \\
146 \\
150\end{array}$ & $\begin{array}{l}85,98 \\
53,28 \\
67,26\end{array}$ \\
\hline Região Sul & 868 & 615 & 70,85 \\
\hline Brasil & 3.855 & 1.663 & 43,14 \\
\hline
\end{tabular}

Fonte: Ministério da Saúde. Área Técnica de Saúde Bucal, 1996. 
Alguns estudos possibilitam um conhecimento mais detalhado das condições em que se dá a fluoretação da água de abastecimento público nos diferentes pontos do país. A implantação da fluoretação da água de abastecimento no Brasil, deu-se a partir da Região Sudeste do país, mais especificamente da cidade de Baixo Guandu, no Estado do Espírito Santo, em 1953 (FREIRE ${ }^{66}, 1962 ;$ FREIRE $\left.^{67}, 1974\right)$. Na capital do Estado, Vitória, a fluoretação das águas somente teve início em 1982. Para a região, o teor ótimo de flúor foi estabelecido em $0,7 \mathrm{mg} / \mathrm{L}$. Antes da implantação da fluoretação, em 1982 realizou-se um levantamento epidemiológico, quando o índice CPO-D registrado foi 9,3 aos 12 anos de idade. Após 14 anos, em 1996, no levantamento realizado pelo Ministério da Saúde, nas capitais brasileiras, O CPO-D de Vitória foi 1,47 aos 12 anos. A cidade já havia atingido a meta proposta pela Organização Mundial de Saúde (OMS) para o ano de 2000, que era a de atingir um índice CPO-D menor ou igual a 3, aos 12 anos de idade (FERREIRA et al. ${ }^{63}, 1999$ ). Devido ao aumento da prevalência e do grau de severidade da fluorose, em 1997, buscou-se verificar a incidência e o grau de fluorose em crianças de 12, 13 e 14 anos que haviam nascido e crescido morando na cidade de Vitória. Foi constatado que $70,8 \%$ das crianças examinadas apresentavam fluorose, sendo que $46,1 \%$ tinham fluorose muito leve; $15,8 \%$ leve; $7,2 \%$ moderada e $1,7 \%$ severa. Através de um questionário aplicado junto aos pais, a causa da fluorose foi atribuída ao bochecho e ao dentifrício fluoretados (SILVA ${ }^{124}$, 1997). Posteriormente, em 1999, foram coletadas amostras de água do bebedouro de 14 escolas selecionadas aleatoriamente, localizadas em 7 microrregiões do município de Vitória. As coletas foram realizadas duas 
vezes, com intervalo de um mês. Os resultados mostraram um teor médio de flúor de 0,40 mg/L na primeira coleta e 0,42 mg/L na segunda, com uma variação de 0,25 a 0,65 mg/L entre as diferentes regiões. Portanto, todas as escolas eram abastecidas com água com uma concentração abaixo da considerada ótima para a região $(0,7 \mathrm{mg} \mathrm{F} / \mathrm{L})$. Os resultados, foram divergentes dos registrados no mesmo período pela companhia responsável pelo tratamento e fluoretação da água, sendo 0,78 mg F/L a concentração média diária, com uma oscilação grande, que variou de 0 a 1,5 mg F/L. Em Vitória, no período de 10 anos, constatou-se que a temperatura média anual aumentou 5 décimos. Este fato, aliado à exposição às múltiplas fontes de ingestão de flúor e à alta prevalência e severidade da fluorose, justificaria o desenvolvimento de um estudo para verificar qual seria a nova concentração ótima de flúor para a água de abastecimento público local. O ajuste na concentração de flúor possibilita a manutenção dos benefícios na redução da prevalência de cárie e da severidade da fluorose dentária. As diferenças no índice CPO-D entre cidades fluoretadas e não fluoretadas vêm diminuindo devido às múltiplas fontes de ingestão de flúor disponíveis (dentifrício, água de abastecimento, bochechos, aplicação tópica de flúor, "efeito halo", ...) (FERREIRA et al. ${ }^{63}$, 1999). Em contrapartida, o índice de fluorose aumenta cada vez mais, sendo que, a água de abastecimento tem sido responsabilizada por $40 \%$ deste quadro epidemiológico de fluorose, sendo os outros 60\% atribuídos às outras fontes de flúor (LEWIS; BANTING $\left.{ }^{82}, 1994\right)$.

A fluoretação de água de abastecimento da cidade de Belo Horizonte iniciou-se em 1975, não havendo desde então nenhum relato de 
períodos de interrupção neste sistema. Embora o nível ideal de 0,74 mg F/L não tenha sido uma constante, a oscilação da concentração de flúor esteve dentro da faixa de 0,6 a 0,8 mg/L, considerada como aceitável. Com o objetivo de avaliar o benefício da fluoretação da água na cidade de Belo Horizonte, durante 18 anos foi analisada a evolução no índice CPO-D dos escolares de 6 a 12 anos de idade, comparando os índices epidemiológicos de cárie dentária. Verificou-se uma redução média do CPO-D de 44,46\%. Constatou-se ainda um aumento de crianças livres de cárie em 25,60\%, sendo que para 6 anos de idade este aumento foi de $52 \%$ e para 12 anos, de $12 \%$. De acordo com os resultados obtidos, o percentual de redução observado, nos 18 anos de implantação de fluoretação de água na cidade de Belo Horizonte, alcançou o máximo de 47\%, aproximadamente no ano de 1986. Esse resultado é inferior aos observados na literatura, que registra uma redução de até $60 \%$ em média após 10 anos de fluoretação da água de abastecimento público. Apesar da redução de cárie ter sido inferior ao esperado, o método pode ser considerado benéfico para as regiões de alta prevalência de cárie (OLIVEIRA; ASSIS; FERREIRA $\left.{ }^{103}, 1995\right)$.

Na cidade do Rio de Janeiro, em 1999, foram avaliadas as condições da fluoretação da água do município, uma vez que dados anteriores, considerando a temperatura da região, apresentaram níveis subótimos de fluoreto de sódio, deixando dúvida quanto à sua regularidade. Foram coletadas 60 amostras de água de diferentes pontos, representando todas as áreas programáticas em que o município estava dividido. Destas amostras, 36 (60\%) apresentaram uma concentração de flúor de apenas de 0,10 a 0,19 mg/L; $13(21,67 \%)$ entre 0,20 e 0,29 mg/L; 5 (8,33\%) entre 0,30 
a 0,39 mg/L; $3(5 \%)$ entre 0,40 e 0,49 mg/L e $3(5 \%)$ entre 0,50 a 0,55mg/L, com uma média de 0,22 mg/L variando de 0,10 a 0,55 mg/L. A fluoretação da água do município do Rio de Janeiro estava sendo realizada de maneira inadequada, sendo necessário adotar medidas para reverter esta situação. Estas medidas devem envolver o Conselho Municipal de Saúde e programas de heterocontrole da concentração de fluoreto na água. Embora o efeito da fluoretação da água de abastecimento tenha sido considerado comprovadamente eficaz na redução da doença cárie dentária em mais de centenas de levantamentos epidemiológicos realizados em quase todo o mundo, incluindo o Brasil, e da agregação do fluoreto ao tratamento da água ser recomendado por organizações científicas e de saúde, uma série de problemas dificulta a manutenção de sua eficiência (MODESTO et al. ${ }^{92}$, 1999).

Ainda na Região Sudeste, no Estado de São Paulo, uma das primeiras cidades do país a adicionar flúor à água de abastecimento público foi Campinas. Iniciou-se em abril de 1962, com concentração de 0,7 mg F/L, quando o índice CPO-D para a idade de 12 anos na cidade era igual a 7,36. Passados 10 anos, em 1972 o índice passou para 3,63, uma redução de cerca de 50\% (VIEGAS; VIEGAS ${ }^{138}$, 1974). Após quatorze anos de fluoretação sem interrupção, em 1976, a tendência de redução da prevalência da cárie dentária mostrou-se evidente, o CPO-D constatado foi 3,3, para 12 anos. A redução na prevalência de cárie manteve-se dentro dos padrões constatos em outros estudos, ou seja, 57\% para a dentição permanente e 49\% para a decídua (VIEGAS; VIEGAS $\left.{ }^{139}, 1985\right)$. 
A cidade de Araraquara passou a fluoretar suas águas a partir de outubro de 1963, com uma concentração de flúor recomendada de 0,8 mg/L. Comparando os índices de cárie para a idade de 12 anos, de 1962 (dados de baseline) e 1982, 19 anos de ingestão de água fluoretada pela população, constatou-se redução na prevalência de cárie, embora menor que a esperada para o período. Em 1962 o CPO-D aos 12 anos era 11,7, e em 1982, 6,8, sendo que em 1972 chegou a 5,5. Analisando os dados do mesmo período, relativos à concentração de flúor na água, foram identificados problemas na manutenção do teor ótimo de flúor, que esteve oscilando entre 0,5 e $1 \mathrm{mg}$ F/L, com tendência para subfluoretação. Esta oscilação na concentração de flúor poderia justificar o aumento da prevalência de cárie quando comparados os índices dos anos de 1972 e 1982, com CPO-D 5,5 e 6,8 respectivamente (VERTUAN $\left.{ }^{136}, 1986\right)$.

Em 1971 procedeu-se a implantação da fluoretação da água de abastecimento em Barretos, onde as crianças de 12 anos de idade apresentavam um CPO-D igual a 8,37. Em 1987, portanto 16 anos de fluoretação na cidade, o índice diminuiu drasticamente, passando para 3,5 para as crianças de 12 anos, muito próximo da meta da OMS para o ano de 2000. Verificou-se ainda que entre as crianças na faixa etária de 5 e 6 anos, 66\% eram livres de cárie, ultrapassando a meta estabalecida pela OMS para a idade, que é de $50 \%$ de livres de cárie (VIEGAS; VIEGAS ${ }^{141}, 1988$ ).

A água de abastecimento público da cidade de Piracicaba (SP) também foi fluoretada a partir de 1971, sendo que, em janeiro de 1987, foi encerrada devido à não disponibilidade de flúorsilicato de sódio. Este fato motivou o desenvolvimento de um estudo com o intuito de relatar a mudança 
na concentração de flúor na placa dentária após a interrupção da fluoretação da água de Piracicaba. Foram coletadas as placas dentárias de 91 crianças de ambos os sexos, de 6 a 8 anos de idade, durante os últimos 6 meses de fluoretação da água (0,8 mg F/L) e de 41 participantes após o encerramento da fluoretação $(0,06 \mathrm{mg} F / L)$. As amostras foram transferidas para tubos de ensaio, centrifugadas e secas. O peso seco da placa para ambos os grupos variou de 1,8 a 4,8 mg, sendo que o peso seco médio foi de $3,3 \mathrm{mg}( \pm 1,5$ mg). Através dos resultados pôde-se observar que a suspensão da fluoretação da água produziu um acentuado decréscimo de flúor na placa, o que pode contribuir para a redução do efeito cariostático decorrente da ingestão de flúor proveniente da água (NOBRE DOS SANTOS; CURY ${ }^{100}$, 1988).

Em 1996, foram analisadas 759 amostras da água de abastecimento público dos municípios com sistema de fluoretação de água, na região de Campinas, pertencentes aos ERSAS (Escritórios Regionais de Saúde) de Amparo, Bragança Paulista, Campinas, Casa Branca, Limeira, Mogi Mirim, Piracicaba, Rio Claro e São João da Boa Vista para subsidiar as autoridades sanitárias no cumprimento da legislação vigente. O teor ótimo de flúor para a região avaliada, é de $0,7 \mathrm{mg} / \mathrm{L}$, sendo de 0,6 a $1 \mathrm{mg} / \mathrm{L}$ os valores mínimo e máximo aceitávies, respectivamente. Verificou-se que dos 76 municípios, apenas $33(43,4 \%)$ fluoretaram com regularidade suas águas de abastecimento, enquanto 9 (11,8\%) fluoretaram de modo descontínuo, 30 (39,5\%) simplesmente não fluoretaram, e apenas em 4 municípios, não foi possível obter informações. Os dados obtidos indicam a necessidade de se incrementar o processo de fluoretação de água para melhorar os resultados 
dos programas de saúde bucal. Para tanto, é necessário controlar de modo efetivo a fluoretação da água de abastecimento público, realizando levantamentos periódicos do teor de flúor na água de abastecimento em diferentes localidades. Quando estes dados da região de Campinas são comparados com os dados relativos ao ano de 1991, verifica-se que o número de municípios que fluoretavam a água de abastecimento diminuiu significativamente e estas observações devem ser estendidas para as demais regiões do Estado. A fluoretação controlada da água é considerada a forma de aplicação do flúor mais importante em Saúde Pública, reduzindo em média $60 \%$ a prevalência de cáries a custos relativamente baixos, sem qualquer tipo de discriminação dos beneficiados da medida (FREITAS et al. $\left.{ }^{69}, 1996\right)$.

Ainda na região de Campinas, em 1995, para verificar a prevalência de cárie dentária, fluorose e opacidades de esmalte de origem não fluorótica em localidades com diferentes concentrações de flúor na água de abastecimento público, foram examinados 610 escolares de 10 a 14 anos, que haviam nascido e residiam nas seguintes localidades: 200 em Iracemápolis-SP (0,1 mg F/L), 211 em Piracicaba-SP (0,7 mg F/L) e 199 em Pereiras-SP (7,0 mg F/L), em alguns poços artesianos. Para o exame de cárie utilizou-se o índice CPO-D; para fluorose, os índices de Dean e TF; em relação às opacidades de esmalte, foram seguidos os critérios de RUSSEL. As médias do CPO-D em Piracicaba, Pereiras e Iracemápolis foram de 3,4, 4,0 e 6,7 respectivamente; enquanto que a prevalência de fluorose foi de 20,4\%, 58,8\% e 2,0\% utilizando o índice TF e de $20,8 \%, 58,8 \%$, e $4,5 \%$ utilizando o índice de Dean. Em Iracemápolis, onde a concentração de flúor 
na água era menor, a porcentagem de opacidades de origem não-fluorótica foi maior (24,5\%); em relação à localidade de maior concentração de flúor na água, Pereiras, a prevalência foi baixa (11\%). Analisando-se os resultados de prevalência de cárie, pode-se observar que Piracicaba e Pereiras apresentaram médias moderadas e próximas da meta que a OMS havia proposto para o ano 2000 (CPO-D S 3); embora em Iracemápolis, a média tenha sido alta (CPO-D=6,7) e distante da meta preconizada pela OMS. Em Pereiras, a prevalência de fluorose foi menor que a esperada, provavelmente pelo hábito, por parte da população, de consumir água de outras fontes, que não a de abastecimento público. Os resultados indicam que quanto maior a concentração de flúor na água de abastecimento público, maior a prevalência de fluorose dentária e menor a prevalência de opacidades de esmalte de origem não fluorótica; e também que em áreas com alta, ótima e baixa concentração de flúor nas águas de abastecimento público, os índices de Dean e TF comportam-se de maneira semelhante (SOARES et al. ${ }^{126}$, 1995).

Após 25 anos de fluoretação da água de abastecimento público de Piracicaba, foi feita uma análise da prevalência de cárie dentária nos escolares a partir dos dados coletados em 1971. Comparando a prevalência em escolares de 7 a 12 anos de idade, verificou-se uma redução do índice CPO-D de 79\%. A evolução no quadro de declíneo da cárie das crianças de 10 anos de idade mostrou-se da seguinte forma: em 1971 o índice CPO-D era 6,17; em 1977 4,09; em 1980 3,52; em 1992, 2,79 e em 1996 1,5. O índice CPO-D encontrado para a idade de 12 anos, foi 2,0. Os resultados indicam que a adição de flúor à água de abastecimento público associada a 
programas preventivos e à utilização de dentifrícios fluoretados, pode levar a uma redução significante do índice de cárie dentária (BASTING; PEREIRA; MENEGHIM $\left.{ }^{10}, 1997\right)$.

Em 1990, foi avaliado o teor de flúor presente na água de abastecimento de 68 cidades da região de Ribeirão Preto pelo método do eletrodo seletivo. Como os dados disponíveis sobre a fluoretação da água de abastecimento público na região eram incompletos e até mesmo conflitantes, esta avaliação teve como finalidade despertar as autoridades locais para a importância da fluoretação da água na prevenção da cárie dentária e a responsabilidade que Ihes cabe pela sua rigorosa execução. Foram encontradas 31 cidades com o teor de flúor na água abaixo de 0,1 mg/L, o que representa 45,5\% das cidades da região. Ainda com relação ao total, 17 cidades apresentaram níveis de flúor na água entre 0,1 e 0,5 mg/L, (25\%); 13 entre 0,5 e 0,7 mg F/L, (19,1\%); 7 entre 0,7 e 1 mg F/L (10,3\%). Apenas 29,4\% das cidades apresentaram a concentração de flúor de suas águas dentro dos níveis considerados representativos para a proteção à cárie dentária, considerando-se o temperatura da região (SPADARO et al. ${ }^{127}$, 1990).

A fluoretação da água do município de São Paulo, foi implantada no ano de 1985 pela Companhia de Saneamento Básico do Estado de São Paulo (SABESP). O teor ótimo de flúor para o município é de 0,7 mg/L. Uma variação de 0,1 mg/L para mais ou para menos em relação à concentração ótima é considerada como aceitável (0,6-0,8 mg/L). Foram feitas coletas mensais de água, de janeiro a dezembro de 1994, no município de São Paulo, representando 62 pontos estrategicamente selecionados. De acordo 
com os resultados, 98\% das amostras foram classificadas como aceitáveis, ao passo que apenas $2 \%$ apresentaram concentração considerada anormal, com baixos teores de flúor. Comparando os resultados com os de anos anteriores, verificou-se que a fluoretação da água de abastecimento de São Paulo encontrava-se numa situação ideal, pois estava sendo realizado um controle eficaz dos limites máximos e mínimos de flúor, a partir de onde se espera uma redução de 50\% na incidência de cárie sem submeter a população a nenhum risco de saúde (ARMONIA et al. $\left.{ }^{4}, 1995\right)$.

Em São Paulo, no ano de 1990, foi implantado um sistema de vigilância. Os resultados para o período de 1990-1999 foram baseados nos dados apresentados nos relatórios anuais, publicados pela Secretaria Municipal de Saúde de São Paulo. Segundo um padrão de classificação das amostras de água, de acordo com a concentração de flúor, verificou-se que $80 \%$ ou mais das amostras analisadas foram consideradas como aceitáveis. Os resultados indicam que a população esteve exposta a níveis adequados de flúor na água neste período. O sistema de vigilância da fluoretação de água de abastecimento público é fundamental para a manutenção dos níveis adequados de flúor (NARVAI $\left.{ }^{98}, 2001\right)$.

O declínio da cárie dentária na cidade de São Paulo entre 1986 e 1996 foi bastante siginificante. Em 1986, as crianças aos 12 anos de idades apresentavam um índice CPO-D de 6,47, uma prevalência considerada alta. Desde então se verificou uma tendência de declínio, atingindo em 1996, um CPO-D de 2,06 aos 12 anos de idade, o que corresponde a um declínio de 68,2\% neste período, com cerca de 39,8\% de livres de cárie. Tal declínio não é uma resultante apenas da fluoretação da água. Estes resultados são 
decorrentes de múltiplos fatores, entre os quais se identificam a fluoretação da água de abastecimento público, os dentifrícios fluoretados e os programas preventivos. Entretanto, quando são considerados outros municípios onde houve a interrupção da fluoretação da água de abastecimento público, os valores do índice CPO-D retornaram aos níveis verificados antes da implantação da fluoretação (Baixo Guandu-ES e Campinas-SP) ou o declínio se deu em porcentagens muito menores do que em São Paulo. Sendo assim, pode-se aceitar a hipótese de que parte significativa do declínio observado deve-se efetivamente à fluoretação da água (NARVAI; CASTELLANOS ${ }^{95}$, 1999; NARVAl; CASTELLANOS; FRAZÃO ${ }^{97}, 2000 ;$ NARVAI $\left.^{98}, 2001\right)$.

No Estado de São Paulo, onde a partir dos anos 80 e 90, observou-se grande expansão na utilização de produtos fluoretados, a água de abastecimento público é considerada como o principal veículo para a administração de flúor. Em 1996, 30,7 milhões de paulistas eram beneficiados com essa medida preventiva, o que corresponde a 79,3\% da população do Estado e a $91,8 \%$ da população com acesso à rede de abastecimento de água tratada $\left(\mathrm{CALVO}^{36}, 1996\right)$. Num esforço conjunto entre CROSP, APCD e Secretaria da Saúde do Estado, foi firmado um acordo com o Governo do Estado em 10 de maio de 2004, onde o governo firma convênio com 116 municípios a fim de que passem a fluoretar suas águas de abastecimento. A exceção é o município de Tejubá, com previsão de participação do convênio, ainda em 2004. Sendo assim, praticamente 100\% da população do Estado passarão a receber o benefício da fluoretação da água de abastecimento público. Na ocasião em que foi 
firmado o acordo, o Governador do Estado declarou: "Não tem como ter saúde se não tiver saúde bucal. O fato de ter um dente infeccionado é porta de entrada, de doenças...." (CONVÊNIO $\left.{ }^{47}, 2004\right)$.

Nas Regiões Centro-Oeste e Sul, alguns estudos mostram a preocupação com a fluoretação. Em Goiânia, os resultados de análises realizadas nas águas de todos os bairros da cidade, em 1999, mostraram grandes e constantes oscilações nos níveis de flúor da água de abastecimento. As amostras que foram coletadas entre os anos de $1997 \mathrm{e}$ 1999 apresetaram como resultados alguns índices preocupantes, variando entre 0,11 a 0,92 mg/L. Portanto, neste período a cidade não conseguiu manter os teores ideais de flúor da água de abastecimento, de maneira contínua (FREIRE et al. ${ }^{68}, 1997$; WERNER $\left.{ }^{142}, 1999\right)$.

No estado do Paraná, em 1958, a cidade de Curitiba, na Região Sul do país, foi a primeira capital de Estado e a quarta cidade do país a adicionar flúor na água de abastecimento público. Após 10 anos de fluoretação observou-se uma redução no índice de cárie em torno de 39,4\% para as idades entre 6 e 12 anos, quando o CPO-D médio, para a idade de 12 anos foi 5,34. Em 1984 o mesmo índice estava em torno de 4 para crianças entre 6 e 12 anos de idade (AMARANTE; JITOMIRSKI; AMARANTE $\left.^{1}, 1993\right)$.

Em Santa Catarina estão localizadas 40\% das reservas brasileiras de fluorita, que é um minério utilizado na indústria de cerâmica, de alumínio e na fluoretação da água de abastecimento público. O distrito de Cacoal, município de Urussanga, encontra-se situado nesta região rica em fluorita, que compreende principalmente a região sudeste de Santa Catarina. Até o 
ano de 1978, o abastecimento de água de Cacoal era feito por meio de fontes superficiais. Com o esgotamento dessas fontes, optou-se por realizar o abastecimento através de poço tubular profundo. De acordo com dados obtidos junto à Fundação SESP, entre os anos de 1985 e 1988 houve uma variação de 1,2 a 5,6 mg/L na concentração de íon flúor na água de abastecimento, superando a faixa ideal para a região, que seria de 0,8 a 1,0 $\mathrm{mg} / \mathrm{L}$, de acordo com a temperatura local. Devido a isso, procedeu-se a um levantamento epidemiológico com 338 crianças de 3 a 10 anos, que nasceram e sempre residiram em Cacoal. Utilizando-se o índice de fluorose de DEAN foi constatado que cerca de $87 \%$ das crianças apresentavam fluorose moderada (escore 3) e severa (escore 4), e, apenas, 2,4\% das crianças eram livres de fluorose. O índice médio final de fluorose encontrado foi de 3,2 ; um resultado preocupante, levando-se em conta que o escore máximo é 4. Os resultados indicaram a necessidade das autoridades sanitárias catarinenses promoverem o controle rigoroso do flúor na água de abastecimento em toda região sudeste do Estado, levando em consideração a presença de reservas naturais de fluorita. Caberia à Fundação SESP providências cabíveis com relação à população de Cacoal atingida pela fluorose, sendo o controle técnico do abastecimento, de sua inteira competência e responsabilidade (CAPELLA et al. ${ }^{38}$, 1989).

A primeira cidade brasileira onde se realizou oficialmente um estudo a respeito dos aspectos da fluoretação das águas de abastecimento público, foi Porto Alegre, em 1944. O estudo teve por objetivo investigar a fluoretação no Estado do Rio Grande do Sul e seus efeitos sob a prevenção da cárie dentária. Entre os anos de 1957 e 1965, foram implantados 71 
sistemas de fluoretação no Rio Grande do Sul, sendo que em 1967, parte destes foi suspenso. Taquara foi a primeira cidade do Estado a fluoretar suas águas, em 1957. Apenas em 1975 é que a capital do Estado, Porto Alegre inciou a fluoretação, sem um levantamento epidemiológico prévio das condições de saúde bucal da população. Desde então as informações a respeito dos benefícios obtidos com a medida não foram sistematizadas. Foram observadas variações bastante siginificativas quando observados os dados da análise da concentração de flúor na água do município. No mês de agosto de 1976, verificou-se uma concentração de 0,62 mg F/L num dado ponto de coleta, sendo que, o mesmo ponto no mês de setembro apresentrou uma concentração de 3,10 mg F/L, seguida por 2,80 mg F/L, 2,40 mg F/L, 2,30 mg F/L nos meses de outubro, novembro e dezembro respectivamente. Em 1987, quando avaliada a concentração de flúor de outro ponto de coleta observaram-se variações entre 0,39 e 0,49 mg F/L. Estes resultados indicam que a população não recebeu o benefício da fluoretação como recomendado (BARROS; TOVO; SCAPINI ${ }^{8}$, 1990; BARROS; SCAPINI; TOVO $\left.{ }^{9}, 1993\right)$.

Antes do uso dos dentifrícios fluoretados em larga escala no Brasil, em 1987, avaliou-se a prevalência de fluorose dentária em escolares de cidades brasileiras com e sem flúor na água de abastecimento. Foram examinadas 435 crianças de 8 e 9 anos de idade de 4 cidades localizadas em duas regiões com condições climáticas distintas: uma com clima subtropical (Porto Alegre - RS e Arroio do Tigre - RS) e outra com clima tropical semi-árido (Brasília - DF e Lusiânia - GO), sendo que uma cidade de cada região tinha água fluoretada e a outra não. Em ambas as regiões foi 
avaliada a prevalência de fluorose através do índice TF (THYLSTRUP e FEJERSKOV). Foi observada uma grande variação na concentração de flúor nas águas de abastecimento artificialmente fluoretadas. Em Porto Alegre, os níveis de flúor variaram de 0,45 a 0,96 mg/L, além das interrupções na fluoretação da água. No ano de 1981 verificou-se o maior período de interrupção da fluoretação, 4 meses. Em Brasília, a concentração de flúor na água variou de 0,32 a 0,72 $\mathrm{mg} / \mathrm{L}$. A prevalência de fluorose dentária foi praticamente nula nas cidades não fluoretadas. No entanto, dentre as fluoretadas, Brasília foi a cidade que apresentou a maior prevalência, 22,3\% das crianças examinadas. Em Porto Alegre a prevalência foi de 7,7\%, sugerindo a influência das condições climáticas sobre a prevalência da fluorose. O grau de fluorose, no entanto, foi baixo, sendo o escore máximo TF2. A prevalência e severidade da fluorose mostraram-se muito baixas nas duas cidades com água fluoretada, sugerindo que somente seu consumo, nas concentrações observadas, não é causa de alta prevalência de fluorose dentária, mesmo em cidades com clima tropical semi-árido com altas temperaturas e conseqüente elevado consumo de água na mesma proporção (CAMPOS et al. ${ }^{37}$, 1998; MALTZ; FARIAS $\left.{ }^{86}, 1998\right)$.

Em 1997/98 observou-se uma importante mudança no quadro epidemiológico de fluorose dentária de duas destas cidades decorridos 10 anos do início da fluoretação dos dentifrícios, entre 1987/1997. Neste período houve uma interrupção de 8 meses na fluoretação da água de abastecimento de Porto Alegre e a concentração de flúor entre 1988 e 1996 variou de 0,10 a 1,02 mg/L. Em Arroio do Tigre, sem adição artificial de flúor na água, a percentagem de crianças com fluorose que era de 0\% em 1987, 
passou para 29,7\% em 1997, e, em Porto Alegre, de 7,7\% para 32,6\%. Em 1987, apenas $0,86 \%$ das crianças TF2 cerca de 6,84\% TF1. No entanto, em 1997/98, 28,1\% das crianças apresentavam TF1 e 3,71\%, TF2. O aumento da prevalência e severidade da fluorose de 1987 para 1997/98, provavelmente se deve ao uso intensivo de diferentes métodos de aplicação tópica combinados, uma vez que, em Arroio do Tigre não há fluoretação da água de abastecimento. Com relação à experiência de cárie, embora tenha sido observada semelhança entre as duas cidades quanto ao número de livres de cárie e dos componentes do índice CPOS, em Arroio do Tigre observou-se que a velocidade de progressão e severidade era maior. Provavelmente este fato se deve à falta de flúor na água de abastecimento. A fluorose constatada nesta população não pode ser considerada como problema de saúde pública, levando-se em conta o nível dos problemas estéticos em relação aos benefícios que o uso do flúor traz para a redução da incidência de cárie (MALTZ et al. ${ }^{87}, 2000$ ).

A manutenção da continuidade da aplicação de flúor na água de abastecimento público, bem como dos níveis adequados de sua concentração, são fundamentais para que a fluoretação da água alcance sua eficácia preventiva no controle da cárie dentária. Os órgãos responsáveis pelo saneamento fazem o controle operacional durante a adição de flúor à água, no entanto, é preciso que além deste controle sejam montados sistemas de vigilância baseados no princípio do heterocontrole (NARVAI ${ }^{98}$, 2001). 


\subsection{A fluoretação da Água de Abastecimento Público na Cidade de Bauru}

A implantação da fluoretação da água de abastecimento público em Bauru, na Estação de Tratamento de Água (ETA), deu-se no dia 10 de outubro de 1975. O Departamento de Água e Esgoto (DAE) do município, após a realização de estudos e observação dos vários tipos de fluoretos em outras localidades, optou pelo fluorsilicato de sódio. Até agosto de 1981, ocorreram algumas interrupções de ordem técnica, o que prejudicou a distribuição de água no nível proposto. Após essa data os aparelhos foram substituídos, e com isso passaram a operar em condições normais. Em 1985, cerca de $71,4 \%$ da população da cidade (130 mil habitantes) recebia água fluoretada, abrangendo as regiões da Central de Abastecimento, Núcleo Presidente Geisel e Parque Vista Alegre. A Estação de Tratamento de Água (ETA) fornecia água fluoretada a 110.000 habitantes, aproximadamente $60,4 \%$ da população abastecida por água tratada, o que correspondia a $84,6 \%$ da população abastecida por água fluoretada. O poço do Núcleo Presidente Geisel beneficiava 9.200 habitantes que correspondia a 5,05\% da população que recebia água tratada, ou seja, $7,07 \%$ da população que era servida por água fluoretada. O poço do Parque Vista Alegre atingia 10.000 habitantes, sendo $5,49 \%$ da população abastecida por água tratada e $7,69 \%$ da população que recebia água fluoretada. Tanto na Estação de Tratamento, quanto no Núcleo Geisel era utilizado o sal fluorsilicato de sódio e, no poço Primavera, localizado no Parque Vista Alegre, era utilizado o ácido fluossilícico (DE PRETO et al. $\left.{ }^{52}, 1985\right)$. 
Com a finalidade de obter os dados de baseline para comparações futuras, foi realizado no início de 1976, um levantamento epidemiológico de cárie dentária, que registrou um CPO-D médio, para a idade de 12 anos, igual a 9,89 (1515 exames). Em 1984 foi realizado um segundo levantamento, quando foi constatado um CPO-D bastante inferior ao de 1975, porém ainda alto, 7,01 para a idade de 12 anos (2416 exames). A diminuição na prevalência de cárie observada no período de 8 anos, variou de $29 \%$ a $36 \%$, de acordo com a faixa etária, sendo que a média foi de $33 \%$. Esse resultado foi inferior aos observados na literatura, a qual apresenta uma redução de até $50 \%$ para o mesmo intervalo de tempo de fluoretação da água de abastecimento público. Contudo, vários fatores podem ter contribuído para este resultado, dentro dos quais, o fato de que vários setores da cidade, em particular, os bairros periféricos, não eram abastecidos com água fluoretada. É possível que, a despeito das escolas se localizarem em área fluoretada, uma parte das crianças examinadas, das 2416, não consumiam água fluoretada. Sendo assim, existe a possibilidade de que as crianças examinadas não faziam parte desta população beneficiada com água fluoretada em suas residências. O hábito da população de consumir água de poços artesianos não fluoretados também deve ser considerado. Um terceiro fator seria de ordem técnica, uma vez que ocorreram algumas interrupções no primeiro ano de fluoretação, seguindo normalmente até 1980, quando novamente houve outra interrupção que perdurou até 1981 , além da falta da manutenção de um controle rígido do processo de fluoretação. Embora o declínio de cárie dentária tenha ficado aquém do esperado, os resultados obtidos embasaram as discussões para 
que se ampliasse o sistema de fluoretação para todo o município e indicaram a necessidade de que a população fosse esclarecida sobre os benefícios do consumo de água fluoretada (DE PRETO et al. ${ }^{52}, 1985$ ).

Os resultados obtidos em outras cidades foram muito superiores aos verificados em Bauru, apenas Piracicaba apresentou uma redução ainda menor no mesmo perído de tempo (TABELA 12).

TABELA 12 - Índice CPO-D médio para a idade de 12 anos em algumas cidades quando iniciada a fluoretação e após um período variando entre 7 a 10 anos de fluoretação da água de abastecimento público

\begin{tabular}{l|c|c|c|c|l}
\hline \multicolumn{1}{c|}{ Cidade } & $\begin{array}{c}\text { CPO-D } \\
\text { Início da } \\
\text { fluoretação }\end{array}$ & $\begin{array}{c}\text { CPO-D } \\
\text { até 10 } \\
\text { anos }\end{array}$ & Período & $\begin{array}{c}\text { Redução } \\
\%\end{array}$ & Referência \\
\hline Araraquara - SP & 11,7 & 5,5 & $1962 / 72$ & 52,99 & Vertuan, 1986 \\
Baixo Guandu - ES & 8,61 & 4,63 & $1953 / 60$ & 46,22 & Freire; Freire, 1962 \\
Barretos - SP & 8,37 & 3,82 & $1971 / 81$ & 54,36 & Viegas; Viegas, 1985 \\
Bauru - SP & 9,89 & 7,01 & $1975 / 84$ & 29,12 & De Preto, et al., 1985 \\
Belo Horizonte - MG & 7,95 & 4,47 & $1975 / 86$ & 43,77 & Oliveira, et al., 1995 \\
Campinas - SP & 7,36 & 3,63 & $1961 / 72$ & 50,67 & Viegas; Viegas, 1974 \\
Curitiba - PR & 8,36 & 5,34 & $1958 / 68$ & 36,12 & Amarante et al., 1993 \\
Piracicaba - SP & 8,6 & 6,17 & $1971 / 80$ & 28,25 & Basting et al.,1997 \\
São Paulo - SP & 6,47 & 2,06 & $1986 / 96$ & 68,16 & Narvai et al., 2000 \\
\hline
\end{tabular}

Após 15 anos da fluoretação das águas de abastecimento público de Bauru, a condição de saúde bucal dos escolares entre 7 e 12 anos de idade foi avaliada com a finalidade de estabelecer uma comparação com os dados de 1976, e ainda, identificar o percentual de crianças com CPO-D igual a zero (livres de cárie). Verificou-se então um índice CPO-D, para a idade de 12 anos igual a 3,97, uma redução média de $60 \%$ do índice de 
cárie e que o percentual de livres de cárie variou entre 13,83\% aos 12 anos de idade e 56,75\% aos 7 anos. Segundo o Departamento de Água e Esgoto (DAE), de Bauru, em 1991, 90\% da água fornecida à população estava recebendo flúor, através da água fornecida pela ETA e pelos 15 poços em atividade na época (BASTOS; FREITAS $\left.{ }^{11}, 1991\right)$.

TABELA 13 - Índice CPO-D médio para a idade de 12 anos em algumas cidades após 10 anos de fluoretação da água de abastecimento público

\begin{tabular}{l|c|c|c|c|l}
\hline \multicolumn{1}{c|}{ Cidade } & $\begin{array}{c}\text { CPO-D } \\
\text { Início da } \\
\text { fluoretação }\end{array}$ & $\begin{array}{c}\text { CPO-D } \\
\text { Após 10 anos }\end{array}$ & Período & $\begin{array}{c}\text { Redução } \\
\%\end{array}$ & Referência \\
\hline Araraquara - SP & 11,7 & 6,8 & $1962 / 82$ & 41,88 & Vertuan, 1986 \\
Baixo Guandu - ES & 8,61 & 2,66 & $1953 / 67$ & 69,10 & Barros et al.; 1993 \\
Barretos - SP & 8,37 & 3,54 & $1971 / 87$ & 57,70 & Viegas; Viegas, 1988 \\
Bauru - SP & 9,89 & 3,97 & $1975 / 90$ & 59,85 & Bastos, et al., 1985 \\
Belo Horizonte - MG & 7,95 & 5,33 & $1975 / 91$ & 32,95 & Oliveira, et al., 1995 \\
Campinas - SP & 7,36 & 3,30 & $1961 / 76$ & 55,16 & Viegas; Viegas, 1985 \\
Grand Rapids - USA & 8,07 & 3,47 & $1945 / 59$ & 57,00 & Bastos et al., 2001 \\
Paulínea - SP & 3,4 & 1,6 & $1980 / 94$ & 52,94 & Moreira et al.,1996 \\
Piracicaba - SP & 8,60 & 3,47 & $1971 / 92$ & 44,11 & Basting et al., 1997 \\
Santos - SP & 8,9 & 5,1 & $1975 / 89$ & 42,69 & Sales Peres, 2001 \\
Vitória - ES & 9,3 & 1,47 & $1982 / 96$ & 84,19 & Ferreira et al., 1999 \\
\hline
\end{tabular}

O inesperado aconteceu. Com o levantamento epidemiológico realizado em 1993, constatou-se um índice CPO-D igual a 4,87 para a idade de 12 anos, observando-se ligeiro, porém importante, aumento no índice de cárie dentária. Este resultado foi muito significativo para chamar a atenção das autoridades de Saúde Pública, de que um programa de prevenção deveria ser implantado e mantido, para que os resultados, uma vez obtidos, fossem mantidos e desta forma as metas estabelecidas pela OMS, alcançadas (POLETTO ${ }^{111}$, 1993). Em 1998 foi realizado o levantamento epidemiológico das condições de saúde bucal da população do Estado de 
São Paulo, quando a cidade de Bauru apresentou o CPO-D igual a 3,42, para a idade de 12 anos, apenas ligeiramente menor que em 1990 (LEVANTAMENTO $\left.{ }^{79}, 1999\right)$.

Em 1997, 59\% da água distribuída na cidade de Bauru, era proveniente da ETA, $29 \%$ de poços com bomba dosadora de flúor, $12 \%$ de poços sem bomba dosadora de flúor. Na ETA a fluoretação era feita pelo método de vazão, onde se adicionava uma determinada quantidade de ácido hidro-fluossilícico $\left(\mathrm{H}_{2} \mathrm{SiF}_{6}\right)$, proporcional à quantidade de água tratada. Os poços artesianos, alguns eram fluoretados por sistema de bombas injetoras, tipo pistão, e outros, por bombas de diafragma, consideradas mais eficientes. Existiam 29 reservatórios de água em Bauru no ano de 1997, sendo que destes 7 recebiam água fluoretada por vazão, diretamente da ETA e os 22 restantes recebiam de poços artesianos. Vale salientar que desses 22 poços artesianos, 14 recebiam fluoretação no local, por bomba dosadora tipo pistão ou diafragma e, os outros 8 poços, não eram fluoretados por problemas técnicos (contrapressão), bombeando a água diretamente para a rede de distribuição. Foram realizadas coletas diárias durante 10 dias, em 40 bairros da cidade e na ETA, sendo que em cada bairro foram coletas 2 amostras de água e na ETA, 1 amostra, perfazendo um total de 810 amostras. A mistura de água de diferentes origens, pela insuficiência no abastecimento de várias regiões, acabou dificultando um levantamento preciso e exato da eficiência na fluoretação da água de abastecimento de Bauru. No mesmo ponto de coleta, uma amostra apresentou o nível de flúor baixo e, na coleta seguinte, a concentração era 10 vezes maior, como pôde ser observado no bairro Bauru 22/26. No bairro 
Vânia Maria, em alguns dias a taxa era de 0,8 a 0,9 mg F/L e em outros caía para 0,2 a 0,3 mg F/L. Por sua vez, a análise da água da ETA, mostrou uma concentração de flúor dentro dos limites estabelecidos pela OMS. No entanto, a região abastecida pela ETA corresponde ao centro e bairros mais nobres (Jardim Estoril, Jardim D. Sarah, Aeroporto), ou seja, beneficiava uma população de nível sócio-econômico elevado. Em contrapartida, uma grande variação na concentração de flúor foi verificada nas regiões mais afastadas do centro e, geralmente, as mais pobres. Outro aspecto a ser considerado, além da diferença do nível sócio-econômico, esta população também estava menos exposta a outras fontes de ingestão de flúor. Das amostras coletadas nos 40 bairros, a concentração de flúor de 16 amostras ficou entre 0 e 0,2 mg/L. Apesar da população receber água fluoretada, 0 problema da distribuição irregular fazia com que alguns bairros não usufruíssem dos benefícios do flúor. A eficiência só foi observada na ETA e em alguns poços. Muitas regiões da cidade apresentaram grande deficiência na fluoretação (NAGEM FILHO et al. $\left.{ }^{94}, 1997\right)$.

O processo de fluoretação das águas de abastecimento público de Bauru, em 1997, foi avaliado mediante monitoramento externo, para identificar as áreas onde a fluoretação estava sendo regular ou não. Durante 6 meses, de fevereiro a julho, foram coletadas e analisadas 55 amostras de água por mês, em 49 diferentes áreas da cidade. A concentração média de flúor, verificada nas 330 amostras de água, mostrou uma variação de 0,05 a 1,4 mg/L. Considerando o teor ótimo de flúor na água do município entre 0,6 e $0,8 \mathrm{mg} / \mathrm{L}$, apenas $16,36 \%$ do total de amostras apresentaram um nível adequado de flúor, ou seja, em apenas 6 dos 49 áreas (pontos) de coleta. 
Um controle rigoroso da quantidade de flúor adicionado à água é indispensável, visando assegurar a manutenção do teor adequado de flúor na água de abastecimento público (TAVARES; BASTOS ${ }^{129}, 1999$ ).

Em 2001, foi confirmada a manutenção da tendência de queda do índice CPO-D, uma vez que o CPO-D médio registrado, para a idade de 12 anos, foi igual a 1,44, uma redução de aproximadamente 63,7\% de 1990 para 2001, portanto, 11 anos depois. O percentual de livres de cárie, em 2001, aos 12 anos de idade foi de 38,39\% e aos 7 anos de idade, de $56,86 \%$. Há que se ressaltar que, para crianças de 7 anos de idade, houve redução de cárie dentária de 94,83\% entre 1976 e 2001, e de 85,44\% , considerando-se escolares de 12 anos de idade, no mesmo período (SALES PERES et al. ${ }^{119}$, 2002; RAMIRES et al. ${ }^{112}$, 2002) (TABELA 13, FIGURA 1). Resultados semelhantes foram observados em Piracicaba, onde após 25 anos de fluoretação, onde o índice CPO-D apresentado pelas crianças, aos 12 anos, foi 2,0 (BASTING; PEREIRA; MENEGHIM ${ }^{10}$, 1997).

Os resultados constatados em Bauru podem estar relacionados principalmente com a melhor observação por parte do DAE das recomendações relativas à fluoretação da água de abastecimento, uso de dentifrícios fluoretados e também, à políticas de saúde pública da Secretaria Municipal de Saúde, como por exemplo o Projeto "Sorria Bauru", resultante da ação conjunta dos "esforços organizados da sociedade". Considerando que a Organização Mundial de Saúde, fixou dentre outras metas para o ano 2010, um índice CPO-D menor ou igual a 1,0, aos 12 anos de idade $\left(\mathrm{OMS}^{106}, 1994 ; \mathrm{FRAZÃO}{ }^{65}, 2003\right)$, Bauru está muito próximo de alcançar antecipadamente esta meta. Para que esta tendência se mantenha é 
fundamental que as medidas de saúde pública adotadas para a prevenção da cárie sejam mantidas e ajustadas. Sendo a fluoretação da água de abastecimento público a medida de maior alcance populacional merece atenção especial na sua manutenção e perpetuação, dentro dos teores adequados de flúor (SALES PERES et al. ${ }^{119}$, 2002; RAMIRES et al. ${ }^{112}$, 2002).

TABELA 14 - Redução de cárie em Bauru para ambos os gêneros, entre 1976, 1990 e 2001

\begin{tabular}{cccccc}
\hline Idade & $\mathbf{1 9 7 6}$ & $\mathbf{1 9 9 0}$ & $\mathbf{2 0 0 1}$ & Diferença & Redução \% \\
\hline 07 & 3,10 & 0,94 & 0,16 & 2,94 & 94,83 \\
08 & 3,98 & 1,48 & 0,42 & 3,56 & 89,44 \\
09 & 5,02 & 2,03 & 0,62 & 4,40 & 87,65 \\
10 & 5,98 & 2,58 & 0,73 & 5,25 & 87,79 \\
11 & 8,16 & 3,27 & 1,16 & 7,00 & 85,79 \\
12 & 9,89 & 3,97 & 1,44 & 8,45 & 85,44 \\
\hline
\end{tabular}

Fonte: RAMIRES et al. ${ }^{112}, 2002$.

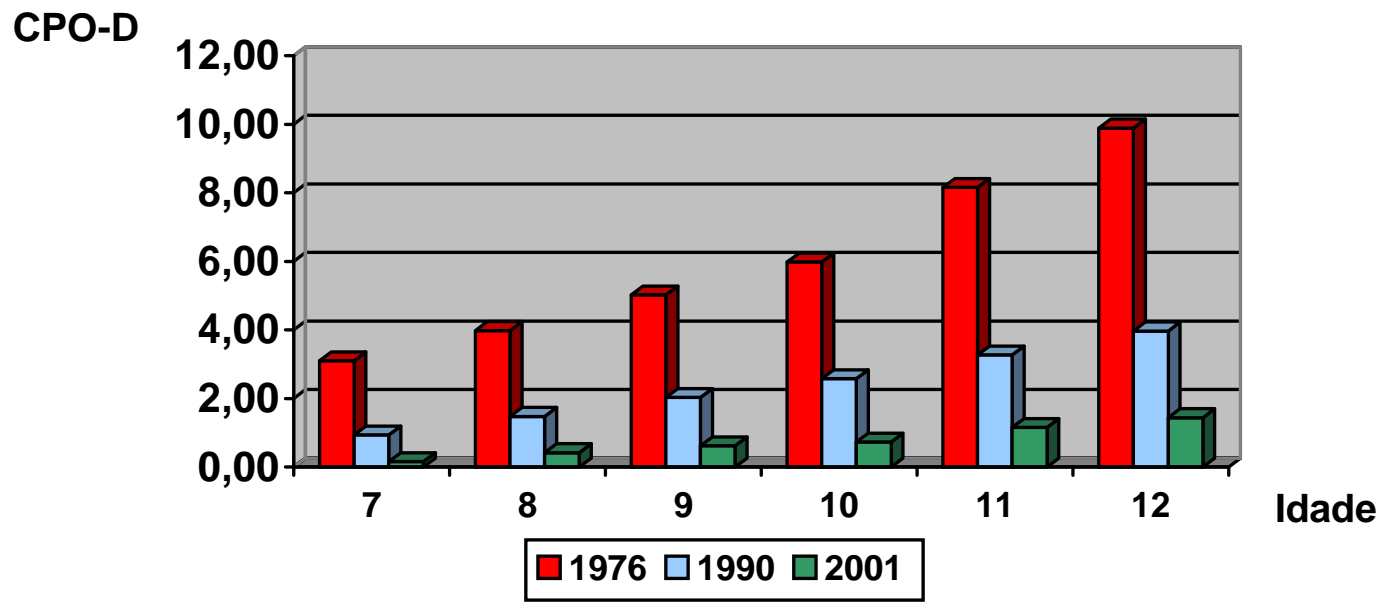

FIGURA 2 - Redução de cárie em Bauru para ambos os gêneros, entre 1976, 1990 e 2001 
Embora os níveis de cárie tenham dado mostra de grande declínio, o problema quanto à manutenção permanente do teor ideal de flúor em 0,7 mg/L, perdura e é constatado em 1999, quando foram coletadas 3 amostras por semana, durante 4 semanas, em 20 pontos de distribuição de água, no período de 2 de julho a 23 de agosto. A concentração de flúor variou de 0,01 a 9,35 mg/L. Houve uma grande variabilidade entre as amostras da mesma área em dias diferentes, e entre áreas diferentes. Uma porcentagem de $82 \%$ das amostras apresentou uma concentração de flúor abaixo do nível mínimo aceitável. Os resultados não apresentaram concordância com os dados fornecidos pelo Departamento de Água e Esgoto, do mesmo período. Curiosamente, na área onde foi constatada uma concentração de 9,35 mg/L em um dia, não houve adição de flúor nos dias subseqüentes. Observou-se uma tendência de hipofluoretação na maioria das áreas analisadas, com grande flutuação no nível de flúor das águas de abastecimento público, fato que pode ser decorrente da fluoretação processar-se no local, em cada um dos poços de forma individual. Faz-se necessário uma melhor informação e treinamento dos funcionários, tanto na formação técnica de manuseio e manutenção do sistema, quanto em relação aos possíveis danos causados à saúde pelas irregularidades na fluoretação. Deve haver um monitoramento mais rigoroso da fluoretação da água, para que apresente níveis satisfatórios e constantes de flúor, próximos do ideal (BUZALAF et al. $\left.{ }^{34}, 2002\right)$.

Novamente em 2003, tem-se a confirmação da falta de manutenção do teor adequado de flúor, entre 0,6 e 0,8 mg/L, em Bauru. Com o objetivo de avaliar a água do setor abastecido pela ETA, que 
corresponde a 44\% da população, foram coletadas amostras de água em 120 residências (abrangendo todos os bairros), em um único dia em outubro de 2002. O procedimento se repetiu em março de 2003. Constatou-se uma variação no teor de flúor entre os bairros abastecidos pela ETA, e também, entre as amostras coletadas no mesmo bairro e na mesma residência, em períodos diferentes. Em outubro de 2002, período em que foi coletado o primeiro lote de amostras, $88,33 \%$ destas, foram classificadas como inaceitáveis, e apenas, 11,67\%, como aceitáveis, ou seja, com a concentração de flúor variando entre 0,6 - 0,8 mg/L. Na segunda etapa, em março de 2003, a concentração de flúor variou de 0,32 a 1,77 mg/L, onde $29,67 \%$ das amostras ficaram fora dos limites considerados como aceitáveis e 70,33\% apresentaram concentração variando entre 0,6 e 0,8 mg F/L. Esta variação é alarmante, uma vez que se esperava uma maior estabilidade no processo de fluoretação realizado na ETA, onde se encontra o laboratório de análises químicas do DAE (LODI; RAMIRES; BASTOS $\left.{ }^{85}, 2003\right)$.

As dificuldades na manutenção dos níveis adequados de flúor na água de abastecimento público fazem com que alguns munucípios deixem de fluoretar suas águas. No entanto, a interrupção da fluoretação traz conseqüências diretas no mecanismo primário de ação do flúor no sítio da lesão em formação. A exposição contínua ao flúor permite alcançar um efeito máximo, devido à manutenção de uma adequada concentração de flúor nos fluidos orais e placa dentária (VERTUAN ${ }^{136}, 1986$; VIEGAS et al. ${ }^{140}$, 1987; NOBRE DOS SANTOS; CURY ${ }^{100}$, 1988; BARROS; SCAPINI; TOVO ${ }^{9}$, 1993; CURY ${ }^{50}$, 2001; BUZALAF et al. ${ }^{34}$, 2002; WHITFORD et al. ${ }^{149}$, 2002). 
3 PROPOSIÇÃo 


\section{ProposiçÃo}

O presente estudo se propós a avaliar a concentração de flúor na água de abastecimento público de Bauru, antes e depois dos procedimentos de fluoretação da água, durante as quatro estações do ano e avaliar as possívies influências exercidas pela temperatura e índice pluviométrico na concentração de flúor naturalmente existente na água. 
4 Material e Métodos 


\section{MATERIAL e MÉtodos}

\subsection{O Sistema de Abastecimento de Água em Bauru}

O abastecimento de água da cidade de Bauru é feito de forma bastante singular, através de uma malha estabelecida entre a ETA, que abastece $44 \%$ da população e os 27 poços artesianos (TABELA 15), que abastecem o restante de $56 \%$ da população, com tratamento convencional de cloração e fluoretação (CONFERÊNCIA MUNICIPAL DE SAÚDE ${ }^{46}$, 2003).

TABELA 15 - Relação dos poços, vazão e ponto de fluoretação. Bauru, 2004

\begin{tabular}{|c|c|c|c|c|}
\hline Poço & $\begin{array}{l}\text { Nome dos } \\
\text { poços }\end{array}$ & $\begin{array}{l}\text { Vazão } \\
\mathrm{m}^{3} / \mathrm{h}\end{array}$ & $\begin{array}{c}\text { Fluoretação } \\
\text { no poço }\end{array}$ & $\begin{array}{l}\text { Fluoretação } \\
\text { no reservatório }\end{array}$ \\
\hline 1 & Jd. América & 90,482 & $\mathrm{X}$ & -- \\
\hline 2 & Parque Real I & 21,932 & $\mathbf{x}$ & -- \\
\hline 3 & Parque Real II & 59,769 & $\mathrm{x}$ & -- \\
\hline 4 & Bauru 16 & 54,026 & -- & $\mathbf{X}$ \\
\hline 5 & Nova Esperança II* & 30,831 & $\mathrm{X}$ & -- \\
\hline 6 & Jaraguá & 98,104 & -- & $\mathbf{X}$ \\
\hline 7 & Distrito Industrial III & 203,349 & $\mathrm{x}$ & -- \\
\hline 8 & Roosevelt II & 177,579 & $\mathbf{x}$ & -- \\
\hline 9 & Vânia Maria & 27,224 & $\mathbf{X}$ & -- \\
\hline 10 & Bíblia & 149,68 & $\mathbf{X}$ & -- \\
\hline 11 & Padilha & 101,426 & -- & $\mathbf{X}$ \\
\hline 12 & Consolação & 59,304 & -- & $\mathbf{X}$ \\
\hline 13 & Primavera & 40,212 & $\mathbf{X}$ & -- \\
\hline 14 & Beija-flor & 173,499 & $\mathbf{X}$ & -- \\
\hline 15 & Santa Cecília & 116,543 & -- & $\mathbf{X}$ \\
\hline 16 & Garrafa & 47,756 & -- & $\mathbf{X}$ \\
\hline 17 & Gasparini & 201,257 & $\mathbf{X}$ & -- \\
\hline 18 & Lotes Urbanizados & 312,151 & $\mathbf{X}$ & -- \\
\hline 19 & Mary Dota & 378,051 & $\mathbf{X}$ & -- \\
\hline 20 & Cruzeiro do Sul & 174,425 & $\mathbf{X}$ & -- \\
\hline 21 & Octávio Rasi & 52,675 & -- & $\mathbf{X}$ \\
\hline 22 & Funcraf (Agroquisa) & 29,392 & $\mathbf{X}$ & -- \\
\hline 23 & Santa Terezinha** & 5,681 & -- & $\mathbf{X}$ \\
\hline 24 & Bauru 25 & 115,323 & $\mathbf{X}$ & -- \\
\hline 25 & Geisel II ( Nicéia II) & 121,875 & $\mathbf{X}$ & -- \\
\hline 26 & Nações Unidas & 214,961 & $\mathbf{X}$ & -- \\
\hline 27 & Samambaia & 187,823 & $\mathbf{X}$ & -- \\
\hline
\end{tabular}

* Nova Esperança - desativado em fevereiro de 2004

** Santa Terezinha - reativado em novembro de 2003 
A água fornecida pela ETA é captada das águas superficiais do manancial do Rio Batalha, enquanto que a dos poços provêm do manancial de águas subterrâneas do Aqüífero Guarani $\left(U^{135}\right.$, 2003). Um sistema aqüífero é constituído de uma formação geológica permeável que aloja água subterrânea em permanente movimento. Os aquíferos ultrapassam limites de fronteiras geográficas, uma vez que a água se infiltra e circula pelo subsolo a grandes distâncias. O aquífero Guarani conta com uma área de 1,2 milhão de quilômetros quadrados, é um dos maiores reservatórios de água doce do mundo e se extende pela Argentina, Brasil, Paraguai e Uruguai (UM $\left.{ }^{135}, 2003\right)$.

A partir de 1990, o Departamento de Água e Esgoto (DAE) alcançou 100\% em cloração e fluoretação da água que em 2003 era distribuída a 99,77\% da população (CONFERÊNCIA MUNICIPAL DE SAÚDE ${ }^{46}$, 2003). A população de 326.392 habitantes é abastecida por uma malha de tubulações com cerca de 1.500 quilômetros de extensão (REDE ${ }^{108}$, 2004). Este abastecimento se dá de quatro diferentes formas: 1) dependendo da vazão do poço e da extensão da área de cobertura do setor, um único poço pode ser a fonte de abastecimento do setor; 2) a água de um poço é associada à água fornecida por um ou mais poços, para o abastecimento de um setor e, o excedente é canalizado para um reservatório; 3) um ou mais poços têm suas águas canalizadas diretamente para um reservatório, e a partir deste, é feito o abastecimento de um ou mais setores. Os poços que abastecem diretamente as residências de um determinado setor têm ligação com outros poços e reservatórios através de uma malha de ligações subterrâneas da rede de abastecimento de água do 
Departamento de Água e Esgoto (DAE). A quarta forma de abastecimento é feita através da ETA (Estação de Tratamento de Água), onde a água proveniente do Rio Batalha passa pelos procedimentos convencionais de tratamento e é distribuída para cerca de 44\% da população.

O sistema de abastecimento de água de Bauru é setorizado (FIGURA 4) e em cada um dos setores um ou mais poços abastecem as residências, além da ETA que é responsável pelo abastecimento do maior e mais populoso setor da cidade (TABELAS 16, 17 e 17.1). Os poços que abastecem as residências para depois abastecerem, com seu excedente de água, os reservatórios, têm seu fornecimento de água interrompido quando o reservatório alcança seu nível máximo de armazenamento de água. Automaticamente, o fornecimento dos poços é interrompido e o abastecimento do setor passa a ser realizado através do retorno da água do reservatório para as residências. Quando o nível mínimo de água do reservatório é alcançado, da mesma forma, o fornecimento de água a partir do reservatório é interrompido e, automaticamente passa a ser feito pelos poços, que iniciarão, também, simultaneamente, o reabastecimento do reservatório com o excedente de água do abastecimento das residências. É um processo contínuo e automatizado, que acontece ininterruptamente desde que não haja alguma falha mecânica dos equipamentos dos poços, ou ainda, por falta de energia. Quando ocorrem falhas ou há necessidade de inspeção para manutenção dos equipamentos, desde que possível, são feitas manobras, que permitem a manutenção do abastecimento enquanto o reparo é realizado. As manobras são possíveis graças à interligação, à 
malha de tubulações que estabelece a ligação entre os poços e reservatórios da rede.

A fluoretação da água de abastecimento público da cidade de Bauru, tem sido realizada com base na média anual das temperaturas máximas diárias, não sendo considerado nenhum outro fator para o estabelecimento da concentração de flúor. Sendo assim, a concentração de flúor considerada como ideal para a cidade é de $0,7 \mathrm{mg} / \mathrm{L}$. Os valores empregados para este cálculo foram preconizados por GALAGAN, VERMILLION, em 1957, quando os dentifrícios e produtos odontológicos contendo flúor, não eram usados em grande escala como passou a acontecer a partir do século 19 (BUZALAF $\left.{ }^{35}, 2002\right)$.

Para obter dados complementares e atualizar as informações a respeito da temperatura da cidade, foi solicitado ao Instituto de Pesquisas Meteorológicas (IPMET), da Universidade Estadual Paulista (UNESP), do Campus de Bauru informações a respeito da temperatura local. Segundo este Instituto a temperatura média do ar (à sombra) nos meses mais quentes é de $26^{\circ} \mathrm{C}$ e nos meses mais frios $20^{\circ} \mathrm{C}$. A média das temperaturas máximas nos meses mais quentes é de 30 a $31^{\circ} \mathrm{C}$ e nos meses mais frios, em torno de $25^{\circ} \mathrm{C}$, apesar de ocorrerem recordes nas temperaturas máximas (próximo de $40^{\circ} \mathrm{C}$ ) nos meses de setembro e outubro. Portanto, de acordo com o relatório fornecido pelo Instituto, os meses de temperaturas mais altas e menores índices de chuva são os de setembro e outubro. A média das temperaturas mínimas nos meses mais quentes está entre 17 e $18^{\circ} \mathrm{C}$ e nos meses mais frios, entre 11 e $13^{\circ} \mathrm{C}$. Recordes entre um máximo próximo de 
$20^{\circ} \mathrm{C}$ e um mínimo em torno de $0^{\circ} \mathrm{C}$, foram observados nos meses mais quentes e frios respectivamente (ANEXO 1).

Embora a fluoretação seja realizada em alguns casos nos poços, em outros, nos reservatórios e, ainda há aquela que é realizada na ETA, o composto é o mesmo e as bombas dosadoras são todas do mesmo tipo (FIGURA 3).

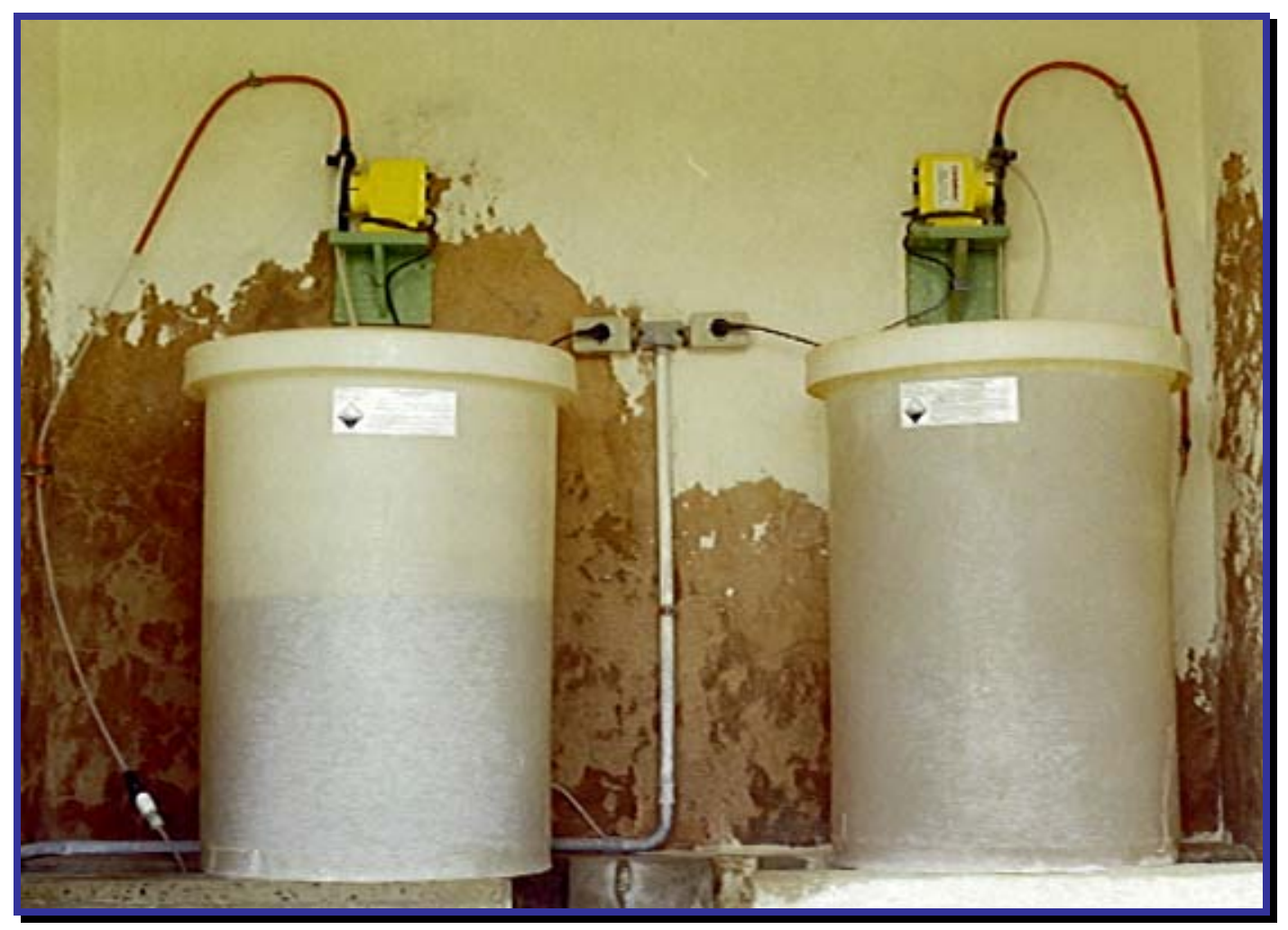

FIGURA 3 - As bombas dosadoras ficam acopladas a cada um dos tanques contendo ácido fluossilícico e cloro 
TABELA 16 - Relação dos bairros abastecidos pela Estação de Tratamento de Água (ETA). Bauru, 2004

Jd Shangri-lá, Jd. OuroVerde, Jd. Vitória, Jd. ferraz, Jd. Solange, Pq. Sabiás, V. Ipiranga, Jd. Terra Branca, Jd. Eugência, V. Santista, V. Serrão, V. S. Francisco, Jd. Gaivota, V. Nipônica, V. Independêcia, Pq. Andorinhas, N. Joaquim Guilherme Francisco de Oliveira, Pq. Viaduto, V. Nova Celina, Jd. Jussara, Chac. Cornélia, V. Industrial, V. Paraíso, V. Souto, V. Falcão, V. Pacífico, Pq. Das Nações, Resid.

Tívole, Jd. Aeroporto, Jd. América, Jd. Paulista, Jd. Estoril I, Jd. Estoril II, Jd. Estoril III, Altos da Cidade, Centro, V. Antarctica, Higienópolis, V. Cardia, V. Carolina, Pq. Paulistano, Jd. Marambá, Jd. Cruzeiro do Sul, Cardia Monlevade e Jd. Guadalajara Fonte: Departamento de Água e Esgoto, 2003.

* ETA - A Estação de Tratamento de Água abastece cerca de 143.612 habitantes da cidade de Bauru (44\% da população). 
TABELA 17 - Relação dos setores, poços, forma de abastecimento e bairros abastecidos. Bauru, 2004

\begin{tabular}{|c|c|c|c|}
\hline Setor & ETA e Poços & $\begin{array}{c}\text { Forma de } \\
\text { abastecimento }\end{array}$ & Bairros abastecidos \\
\hline I & Jd. América e ETA & Direto & Jd. América (parte) e Europa \\
\hline II & $\begin{array}{l}\text { Parque Real I } \\
\text { Parque Real II }\end{array}$ & $\begin{array}{l}\text { Direto } \\
\text { Direto }\end{array}$ & $\begin{array}{l}\text { Pq. Real, Santa Cândida, V. Dutra } \\
\text { V. Industrial (parte), N. Leão XIII, } \\
\text { I e III }\end{array}$ \\
\hline III & Bauru 16 & Indireto & $\begin{array}{l}\text { N. Bauru 16, Parque Val de Palamas } \\
\text { E V. Edson Francisco }\end{array}$ \\
\hline IV & $\begin{array}{l}\text { Nova Esperança II } \\
\text { Distrito Industrial III } \\
\text { Jaraguá II }\end{array}$ & $\begin{array}{l}\text { Direto } \\
\text { Direto } \\
\text { Indireto }\end{array}$ & $\begin{array}{l}\text { Nova Esperança, Jd. Eldorado II, } \\
\text { V. Prudência, Santa Filomena, Jd. da } \\
\text { Grama, Pq. Marilu e V. Industrial }\end{array}$ \\
\hline V & $\begin{array}{l}\text { Distrito Industrial III } \\
\text { Roosevelt II } \\
\text { Vânia Maria } \\
\text { Gasparini }\end{array}$ & $\begin{array}{l}\text { Direto } \\
\text { Direto } \\
\text { Direto } \\
\text { Direto }\end{array}$ & $\begin{array}{l}\text { Pq. Jaraguá, Distrito Industrial III, } \\
\text { N. } 9 \text { de Julho, Santa Fé, Fortunato } \\
\text { Rocha Lima, Alto Alegre, Petrópoles, } \\
\text { Marajoara, V. Lemos e Pq. União (par } \\
\text { te), Marajoara }\end{array}$ \\
\hline VI & Vânia Maria & Direto & Vânia Maria \\
\hline VII & $\begin{array}{l}\text { Bíblia } \\
\text { Padilha } \\
\text { Consolação }\end{array}$ & $\begin{array}{l}\text { Direto } \\
\text { Indireto } \\
\text { Indireto }\end{array}$ & $\begin{array}{l}\text { Bela Vista, V. Quagio, Pq. União, V. } \\
\text { Lemos, Gernson França e V. Seabra }\end{array}$ \\
\hline VIII & $\begin{array}{l}\text { Primavera } \\
\text { Beija-flor }\end{array}$ & $\begin{array}{l}\text { Direto } \\
\text { Direto }\end{array}$ & $\begin{array}{l}\text { Pq. Vista Alegre (parte baixa), Pq. } \\
\text { Sumaré ,Jd. Santana e Jd. Araruna }\end{array}$ \\
\hline IX & $\begin{array}{l}\text { Santa Cecília } \\
\text { Garrafa } \\
\text { Beija-flor }\end{array}$ & $\begin{array}{l}\text { Indireto } \\
\text { Indireto } \\
\text { Direto }\end{array}$ & $\begin{array}{l}\text { Pq. São Geraldo, Pq. City, Pq. Vista } \\
\text { Alegre (parte alta), Jd. Godoy, Jd. } \\
\text { Colina Verde, Jd. Pagani e Sta. Cecília }\end{array}$ \\
\hline$x$ & Gasparini & Direto & $\begin{array}{l}\text { N. Gasparini, Nanoire, V, Sào Paulo, } \\
\text { Vila Garcia (parte), Pousada I, Jd. TV, } \\
\text { Jd. Ivone e Jd. Helena }\end{array}$ \\
\hline XI & $\begin{array}{l}\text { Lotes Urbanizados } \\
\text { (Poço Zona Norte) }\end{array}$ & Direto & $\begin{array}{l}\text { N. Nova Bauru, Pousada II, Quinta } \\
\text { da Bela Olinda e Bauru 2000, Lotes } \\
\text { Urbanizados e N. Nobuja Nagasaua }\end{array}$ \\
\hline XII & Mary Dota & Direto & $\begin{array}{l}\text { N. Mary Dota, N. Beija Flor, Sta. Luzia, } \\
\text { Eldorado I, Jd. Flórida, Jd. Silvestre, } \\
\text { Jd. Chapadão, Jd. Mendonça e Pq. } \\
\text { Rossi }\end{array}$ \\
\hline
\end{tabular}

Fonte: Departamento de Água e Esgoto, 2003. 
TABELA 17.1 - Relação dos setores, poços, forma de abastecimento e bairros abastecidos. Bauru, 2004

\begin{tabular}{|c|c|c|c|}
\hline Setor & ETA e Poços & $\begin{array}{c}\text { Forma de } \\
\text { abastecimento }\end{array}$ & Bairros abastecidos \\
\hline XIV & Octávio Rasi & Indireto & $\begin{array}{l}\text { Jd. CECAP, Jd. Carolina (parte), Jd. } \\
\text { Redentor, Mutirão Primavera, Pq. } \\
\text { Júlio Nóbrega, Pq. Bauru, Distrito } \\
\text { Industrial I e Pq. Paulista } \\
\text { N. Octávio Rasi e Distrito Industrial I } \\
\text { (parte) }\end{array}$ \\
\hline xV & $\begin{array}{l}\text { Funcraf (Agroquisa) } \\
\text { Santa Terezinha }\end{array}$ & $\begin{array}{l}\text { Direto } \\
\text { Indireto }\end{array}$ & $\begin{array}{l}\text { Pq. Manchester, Santa Terezinha e } \\
\text { Distrito Industrial II }\end{array}$ \\
\hline XVI & Bauru 25 & Direto & $\begin{array}{l}\text { José Regino, Jd. das Orquídeas, Pq. } \\
\text { Bauru, N. Geisel e Jd. Tangarás }\end{array}$ \\
\hline XVII & Geisel II (Jd. Nicéia) & Direto & Carolina, Jd. Nicéia e N. Geisel \\
\hline XVIII & Nações & Direto & $\begin{array}{l}\text { V. Universitária, Jd.Panorama, Jd. } \\
\text { Aeroporto, Jd. Samburá, Jd. Contorno } \\
\text { e Jd. Brasil }\end{array}$ \\
\hline XIX & Samambaia & Direto & $\begin{array}{l}\text { Cond. Paineiras, V. Aviação, Jd. } \\
\text { Nicéia, Cond. Samambaia, } \\
\text { Cond. Jd. Colonial, Jd. Marabá, } \\
\text { Jd. Europa (parte alta) e Jd. Santos }\end{array}$ \\
\hline
\end{tabular}

Fonte: Departamento de Água e Esgoto, 2003. 


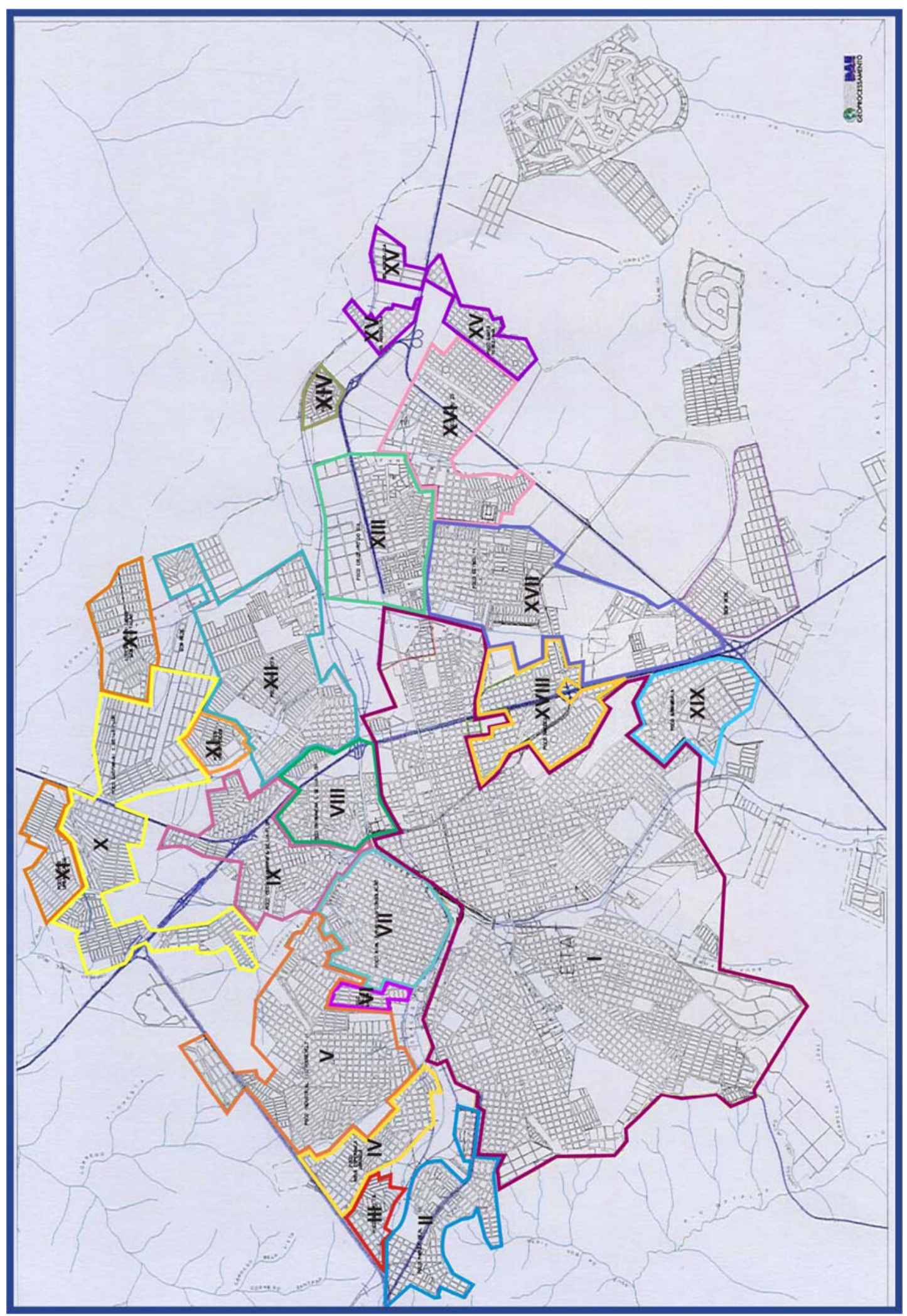

FIGURA 4 - Localização dos 19 setores de abastecimento no mapa da cidade de Bauru, 2004 


\subsection{MATERIAL}

Parte do material utilizado para a realização da pesquisa foi adquirido pelo Departamento de Ciências Biológicas, área de Bioquímica da FOB/USP. Os aparelhos e soluções empregadas nas análises das amostras também foram cedidos pela Bioquímica.

Equipamentos e material usados:

- $\quad$ eletrodo íon sensível Orion 9609;

- potenciômetro/Procyon, modelo 720;

- agitador;

- cronômetro;

- $\quad$ pipetas de $1000 \mu \mathrm{L}$;

- ponteiras de $1000 \mu \mathrm{L}$;

- frascos J10;

- frascos plásticos de 50 mL;

- computador;

Reagentes usados:

- $\quad$ soluções padrão 0,1, 0,2, 0,4, 0,8, 1,6, 3,2 mgF;

- solução de preenchimento do eletrodo;

- solução tampão TISAB II;

- água deionizada. 


\subsection{MÉtodos}

Para avaliar a concentração de flúor antes e depois da fluoretação, bem como as possíveis influências exercidas pela temperatura e índice de chuvas do período, estabeleceu-se um protocolo com duração de um ano. A coleta de amostras de água foi realizada durante três dias de uma semana, a cada três meses durante as quatro estações do ano, ou seja, nos meses de maio, agosto, novembro de 2003 e fevereiro de 2004.

Devido à necessidade de entrar nas instalações de cada um dos poços, bem como da ETA, para a coleta das amostras antes e imediatamente após a fluoretação, fez-se necessário que, funcionários do DAE acompanhassem as coletas. Para tanto, foi solicitada autorização à Presidência do Departamento de Água e Esgoto (DAE), via ofício, para que tal pesquisa pudesse ser realizada. Para possibilitar a programação do cronograma de atividades por parte da autarquia, permitindo que dois funcionários pudessem estar disponíveis para acompanharem a coleta, as datas foram previamente estabelecidas: maio (19-21-23), agosto (18-20-22), novembro (17-19-21) de 2003, e no mês de fevereiro (16-18-20) de 2004 realizando-se a coleta no meio de cada estação do ano (outono, inverno, primavera e verão, respectivamente). O ofício de autorização da Presidência do DAE para a realização da pesquisa está em apêndice (APÊNDICE 1). 


\subsubsection{Definição da amostra}

Para a definição da amostra, foi realizada uma reunião entre o funcionário do DAE, responsável pelo setor de distribuição de água em Bauru e a pesquisadora, com a finalidade de entender o mecanismo de distribuição de água no município.

Em função do sistema de abastecimento de água adotado no município de Bauru, o DAE estabeleceu 19 setores de abastecimento (FIGURA 4). As amostras de água deveriam ser coletadas em 27 poços antes e depois da fluoretação e na ETA (FIGURA 5), além dos 63 pontos de coleta, que foram definidos e fixados, a partir do mapa do município que estabelece a setorização da distribuição de água (FIGURA 6, TABELAS 18, 18.1). Em cada um dos setores abastecidos por poços foram coletadas 3 amostras em 3 diferentes pontos e, no setor abastecido pela ETA, 6 amostras em 6 diferentes pontos, de forma a abranger toda a rede municipal de abastecimento. O setor da ETA foi privilegiado com um número maior de amostras (6) por corresponder a $44 \%$ do abastecimento realizado pelo DAE. Sendo o maior setor de abastecimento da cidade, sua área de abrangência faz limite com vários outros setores de abastecimento, daí a importância em se verificar a manutenção da concentração de flúor em toda a sua extensão. A exceção foi o setor abastecido pelo poço Lotes Urbanizados, onde também foram coletadas 6 amostras. Este procedimento foi adotado pelo fato desse poço cobrir uma área geograficamente descontinua, e daí a necessidade de se investigar a manutenção da concentração de flúor em toda a sua extensão. O total de amostras coletadas por dia, na semana de coleta (segunda, quarta e sexta-feira), foi de 27 amostras de água dos poços 
antes da fluoretação, 24 depois, 1 da ETA antes e 1 depois, e 63 das residências. Os poços Padilha e Consolação têm suas águas fluoretadas no reservatório, daí ser coletada uma única amostra depois da fluoretação. O mesmo procedimento foi adotado com relação aos poços Funcraf e Santa Terezinha, Santa Cecília e Garrafa, que também têm suas águas fluoretadas em um mesmo ponto. Portanto, de acordo com o protocolo definido deveriam ser coletadas, por semana, 81 amostras de água dos poços antes da fluoretacão, 72 depois, 3 antes e 3 depois da ETA e 189 das residências, totalizando 348 amostras por semana (em cada estação do ano) e 1392 durante o tempo de duração da pesquisa. 


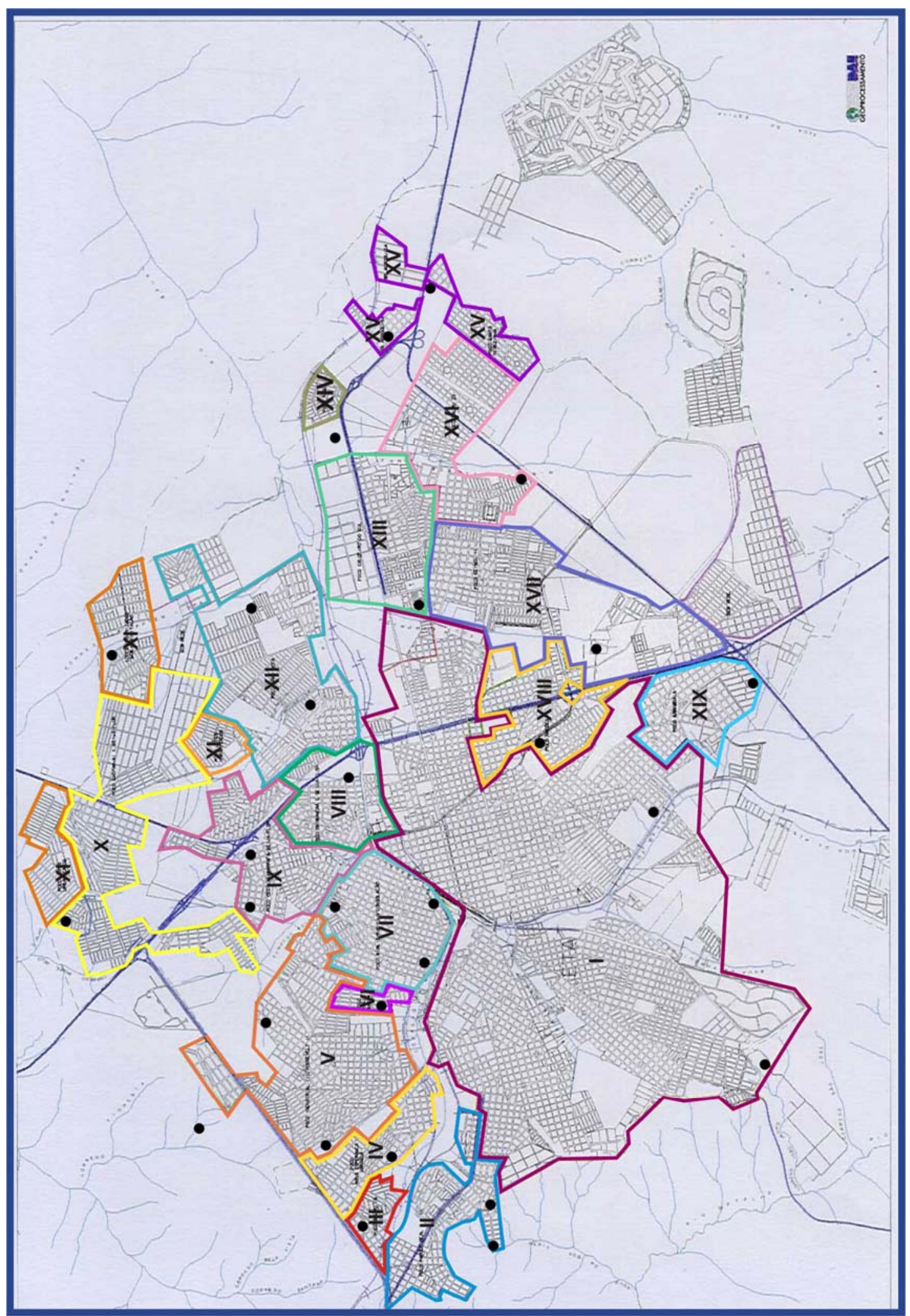

FIGURA 5 - Localização da ETA e dos 27 poços no mapa onde estão definidos os setores de abastecimento da cidade de Bauru, 2004. 


\subsection{2 - Pontos de Coleta}

A coleta das amostras de água antes e depois da fluoretação na ETA nos poços foi realizada no local onde se encontra o poço (FIGURA 5). Os pontos de coleta de amostra de água que chega nas residências foram estabelecidos de forma a cobrir os diferentes setores de abastecimento da cidade (FIGURA 6, TABELAS 18 e 18.1).

TABELA 18 - Pontos de coleta de amostra de água segundo o número e o nome do setor de abastecimento de cada um dos poços, bairro e o número do ponto de coleta

\begin{tabular}{|c|c|c|c|}
\hline $\begin{array}{l}\mathrm{N} \text { do } \\
\text { Setor }\end{array}$ & Nome do Setor & Nome do Bairro & Ponto \\
\hline $\mathbf{I}$ & Setor da ETA & $\begin{array}{l}\text { Jd. Sangri-lá } \\
\text { Jd. Europa } \\
\text { V. Aviação } \\
\text { Jd. Sangri-lá } \\
\text { V. Souto } \\
\text { Altos da Cidade }\end{array}$ & $\begin{array}{l}1 \\
2 \\
3 \\
4 \\
5 \\
6\end{array}$ \\
\hline II & Parque Real I e Parque Real II & $\begin{array}{l}\text { P. S. Cândida } \\
\text { V. Dutra } \\
\text { P. Real }\end{array}$ & $\begin{array}{l}7 \\
8 \\
9\end{array}$ \\
\hline III & Bauru 16 & $\begin{array}{l}\text { V. Edson Francisco } \\
\text { V. Edson Francisco } \\
\text { V. Edson Francisco }\end{array}$ & $\begin{array}{l}10 \\
11 \\
12\end{array}$ \\
\hline IV & Nova Esperança/Jaraguá & $\begin{array}{l}\text { V. Industrial } \\
\text { V. Industrial } \\
\text { Jd. Prudência }\end{array}$ & $\begin{array}{l}13 \\
14 \\
15\end{array}$ \\
\hline V & Industrial III/Roosevelt II & $\begin{array}{l}\text { S. Edwirges } \\
\text { S. Edwirges } \\
\text { P. Jaraguá }\end{array}$ & $\begin{array}{l}16 \\
17 \\
18\end{array}$ \\
\hline VI & Vânia Maria & $\begin{array}{l}\text { Vânia Maria } \\
\text { Vânia Maria } \\
\text { Vânia Maria }\end{array}$ & $\begin{array}{l}19 \\
20 \\
21\end{array}$ \\
\hline VII & Bíblia/Padilha/Consolação & $\begin{array}{l}\text { Bela Vista } \\
\text { V. Lemos } \\
\text { V. Gonçalves }\end{array}$ & $\begin{array}{l}22 \\
23 \\
24\end{array}$ \\
\hline VIII & Primavera/Beija Flor & $\begin{array}{l}\text { Jd. Santana } \\
\text { Jd. Araruna } \\
\text { P. Vista Alegre }\end{array}$ & $\begin{array}{l}25 \\
26 \\
27\end{array}$ \\
\hline
\end{tabular}


TABELA 18.1 - Pontos de coleta de amostra de água segundo o número e o nome do setor de abastecimento de cada um dos poços, bairro e o número do ponto de coleta

\begin{tabular}{|c|c|c|c|}
\hline $\begin{array}{l}\text { N do } \\
\text { Setor }\end{array}$ & Nome do Setor & Nome do Bairro & Ponto \\
\hline IX & SantaCecília/Garrafa/Beija Flor & $\begin{array}{l}\text { P. São Geraldo } \\
\text { P. Perdizes } \\
\text { P. S. Cecília }\end{array}$ & $\begin{array}{l}28 \\
29 \\
30\end{array}$ \\
\hline $\mathrm{X}$ & Gasparini & $\begin{array}{l}\text { Núcleo Gasparini } \\
\text { V. São Paulo }\end{array}$ & $\begin{array}{l}32 \\
33\end{array}$ \\
\hline $\mathbf{X I}$ & Lotes Urbanizados & $\begin{array}{l}\text { Pousada da Esperança II } \\
\text { Pousada da Esperança II } \\
\text { Nova Bauru } \\
\text { N. H. Nobuja Nagasawa } \\
\text { N. H. Nobuja Nagasawa } \\
\text { N. H. Nobuja Nagasawa }\end{array}$ & $\begin{array}{l}34 \\
35 \\
36 \\
37 \\
38 \\
39\end{array}$ \\
\hline XII & Mary Dota & $\begin{array}{l}\text { Nova Santa Luzia } \\
\text { Núcleo Mary Dota } \\
\text { Jd. Chapadão }\end{array}$ & $\begin{array}{l}40 \\
41 \\
42\end{array}$ \\
\hline XIII & Cruzeiro do Sul & $\begin{array}{l}\text { P. Paulista } \\
\text { Redentor } \\
\text { P. Júlio Nóbrega }\end{array}$ & $\begin{array}{l}43 \\
44 \\
45\end{array}$ \\
\hline XIV & Octávio Rasi & $\begin{array}{l}\text { N. Octávio Rasi } \\
\text { N. Octávio Rasi } \\
\text { N. Octávio Rasi }\end{array}$ & $\begin{array}{l}46 \\
47 \\
48\end{array}$ \\
\hline XV & Funcraf/Santa Terezinha & $\begin{array}{l}\text { P. S. Terezinha } \\
\text { P. Manchester } \\
\text { P. Aimorés }\end{array}$ & $\begin{array}{l}49 \\
50 \\
51\end{array}$ \\
\hline $\mathbf{X V I}$ & Bauru 25 & $\begin{array}{l}\text { Tangaras } \\
\text { P. Bauru } \\
\text { N. José Regino }\end{array}$ & $\begin{array}{l}52 \\
53 \\
54\end{array}$ \\
\hline XVII & Geisel II & $\begin{array}{l}\text { P. Geisel } \\
\text { Jd. Carolina } \\
\text { Jd. Nicéia }\end{array}$ & $\begin{array}{l}55 \\
56 \\
57\end{array}$ \\
\hline XVIII & Nações & $\begin{array}{l}\text { Jd. Planalto } \\
\text { Jd. Brasil } \\
\text { P. Camélias }\end{array}$ & $\begin{array}{l}58 \\
59 \\
60\end{array}$ \\
\hline XIX & Samambaia & $\begin{array}{l}\text { Samambaia } \\
\text { Jd. Europa } \\
\text { Vila Aviação }\end{array}$ & $\begin{array}{l}61 \\
62 \\
63\end{array}$ \\
\hline
\end{tabular}




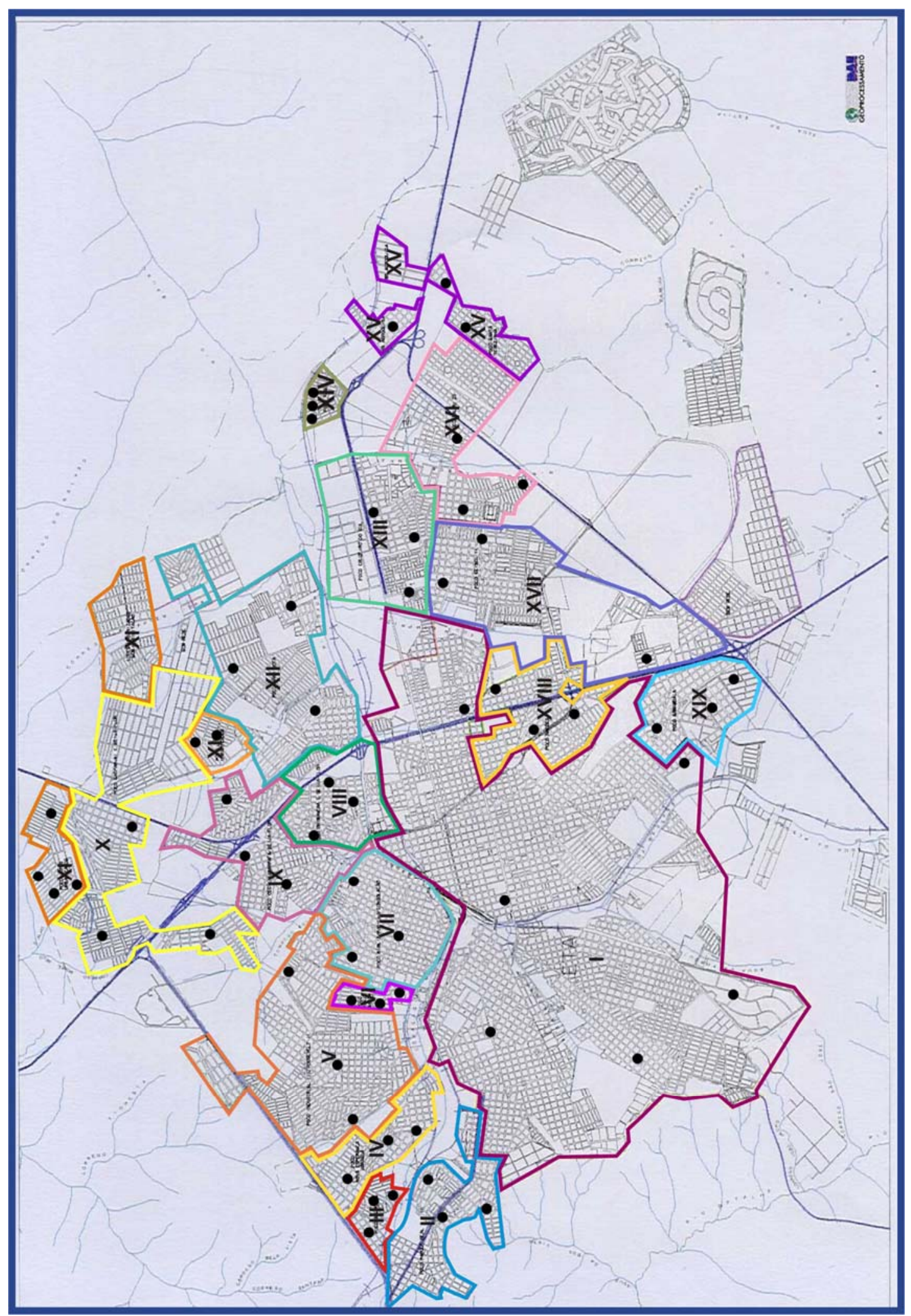

FIGURA 6 - Localização dos 63 pontos de coleta de amostras de água, em cada um dos 19 setores de abastecimento da cidade de Bauru, 2004 


\subsection{3 - Responsável pela coleta da amostra}

\section{Amostras dos poços e ETA}

As amostras de água dos poços e da ETA, antes e imediatamente após à fluoretação foram coletadas pela pesquisadora com 0 acompanhamento de um técnico do Laboratório de Química do DAE e um funcionário da manutenção da mesma autarquia, para que fosse possível entrar e ter acesso às instalações dos poços para realizar a coleta de água (FIGURAS 7, 8, 9, 10 e 11).

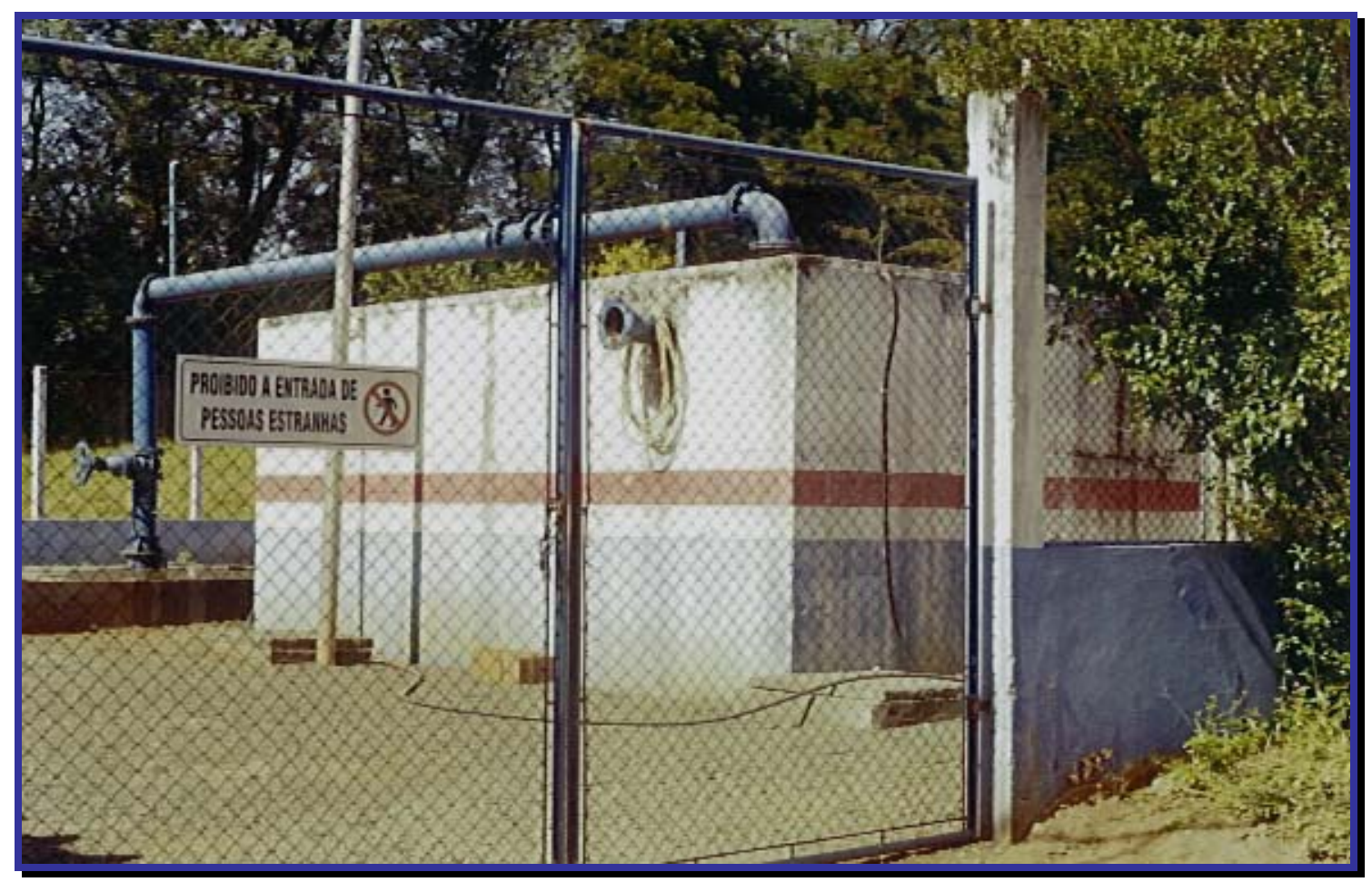

FIGURA 7 - Todos os poços são mantidos fechados e com entrada proibida para pessoas estranhas ao DAE. 


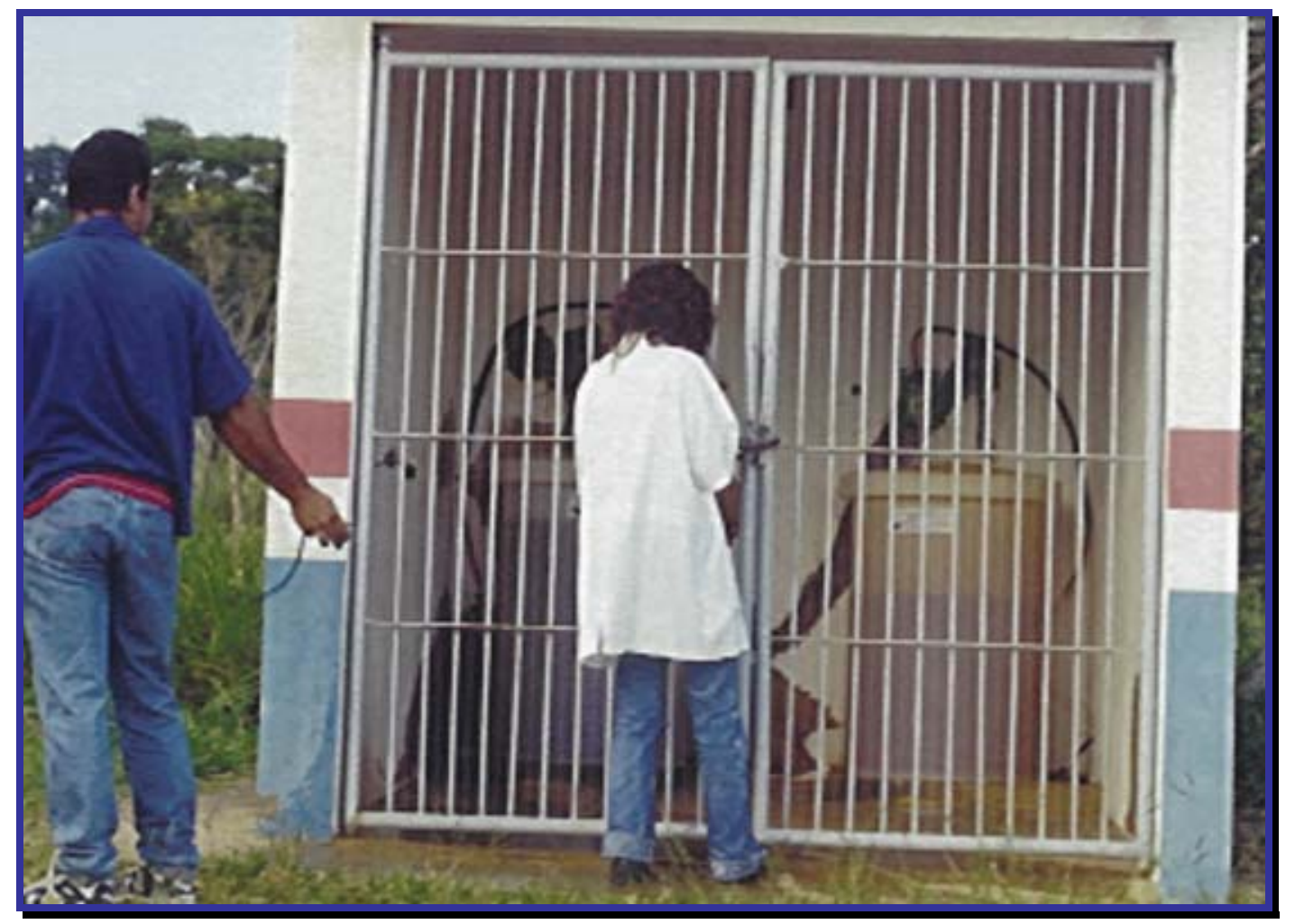

FIGURA 8 - Bombas dosadoras e os tanques contendo ácido fluossilícico e cloro são mantidas em instalações fechadas

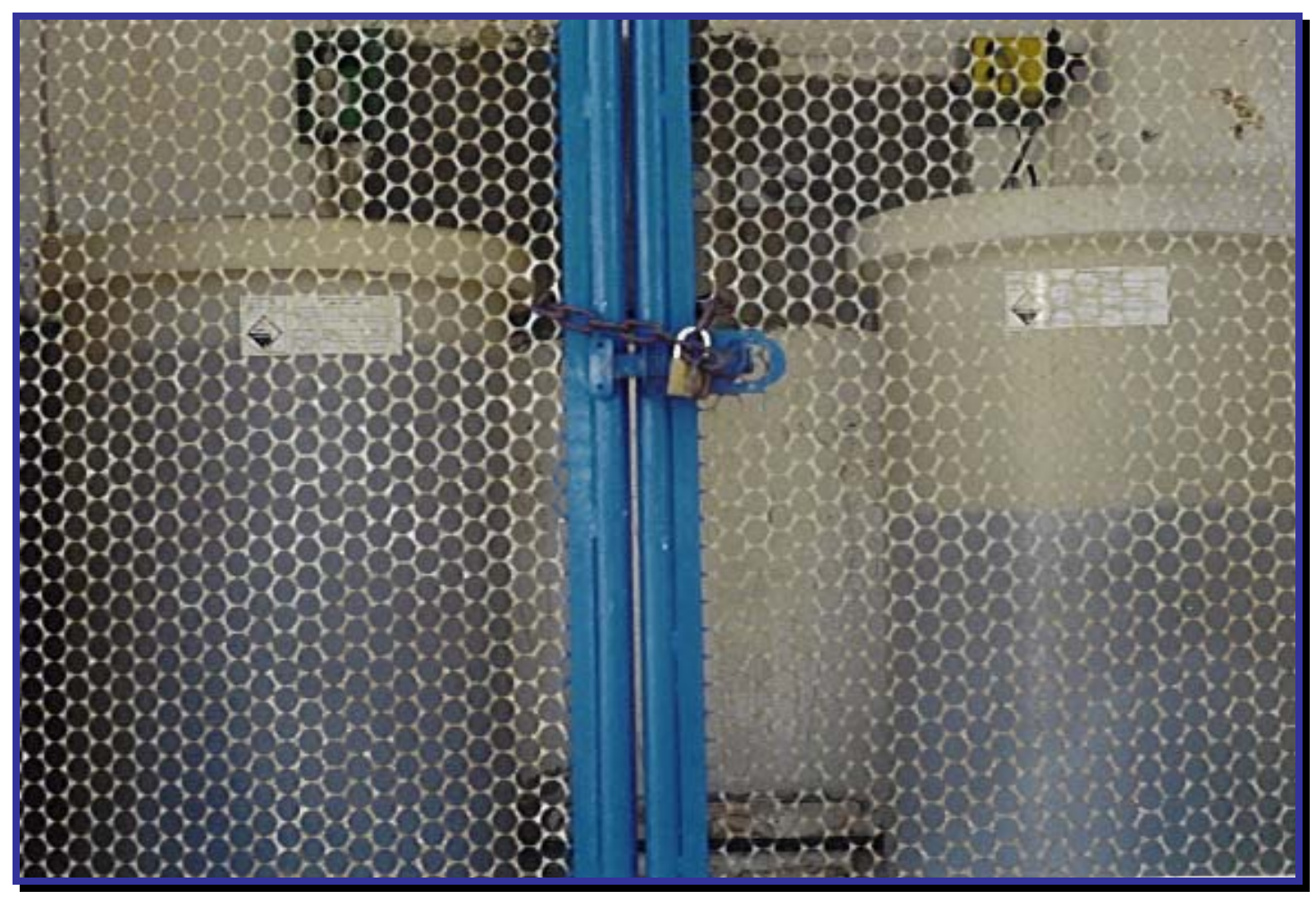

FIGURA 9 - Instalações com as bombas dosadoras de cloro e flúor 


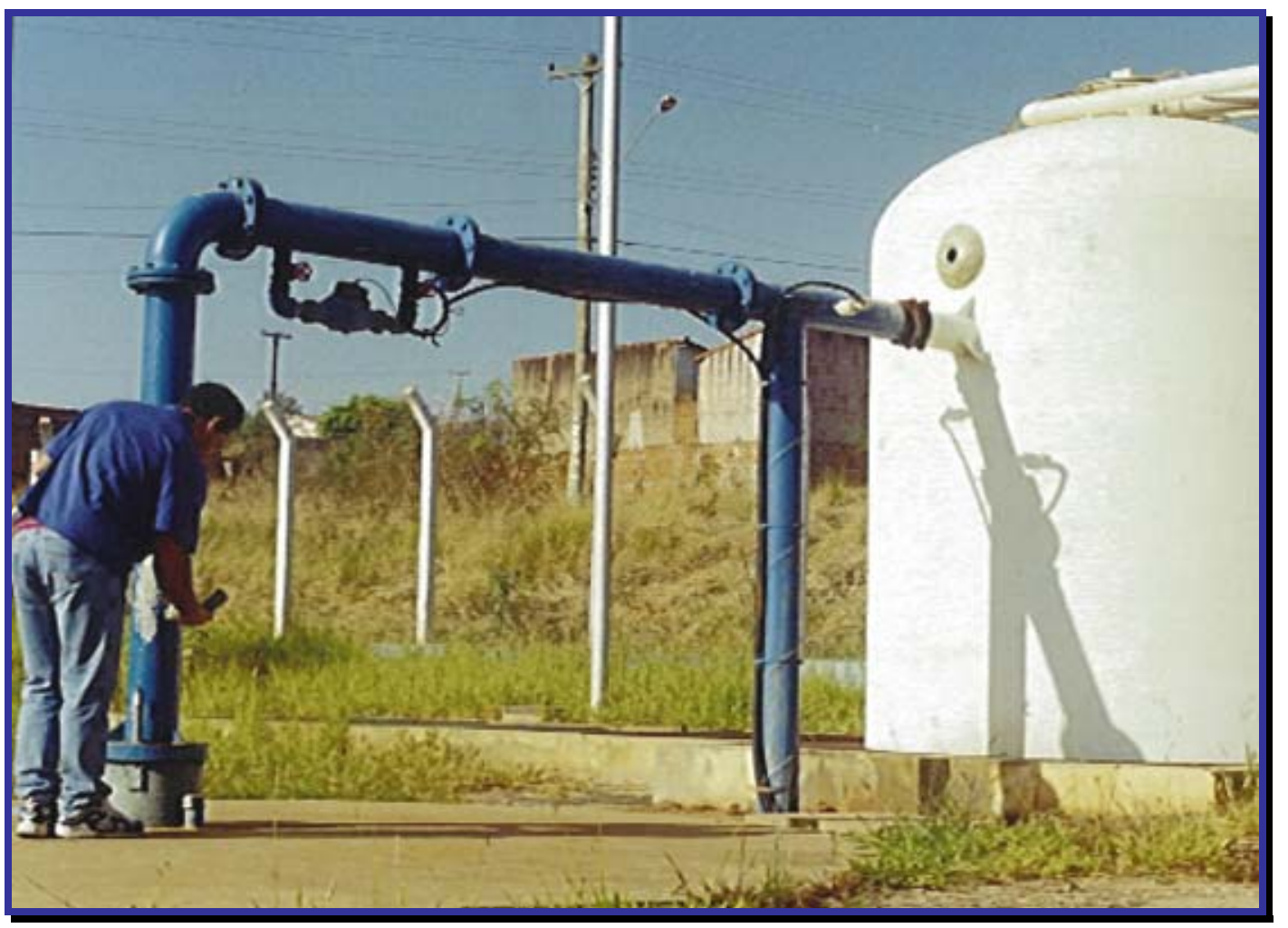

FIGURA 10 - O uso de equipamentos adequados para abertura da tubulação possibilitando a coleta de água.

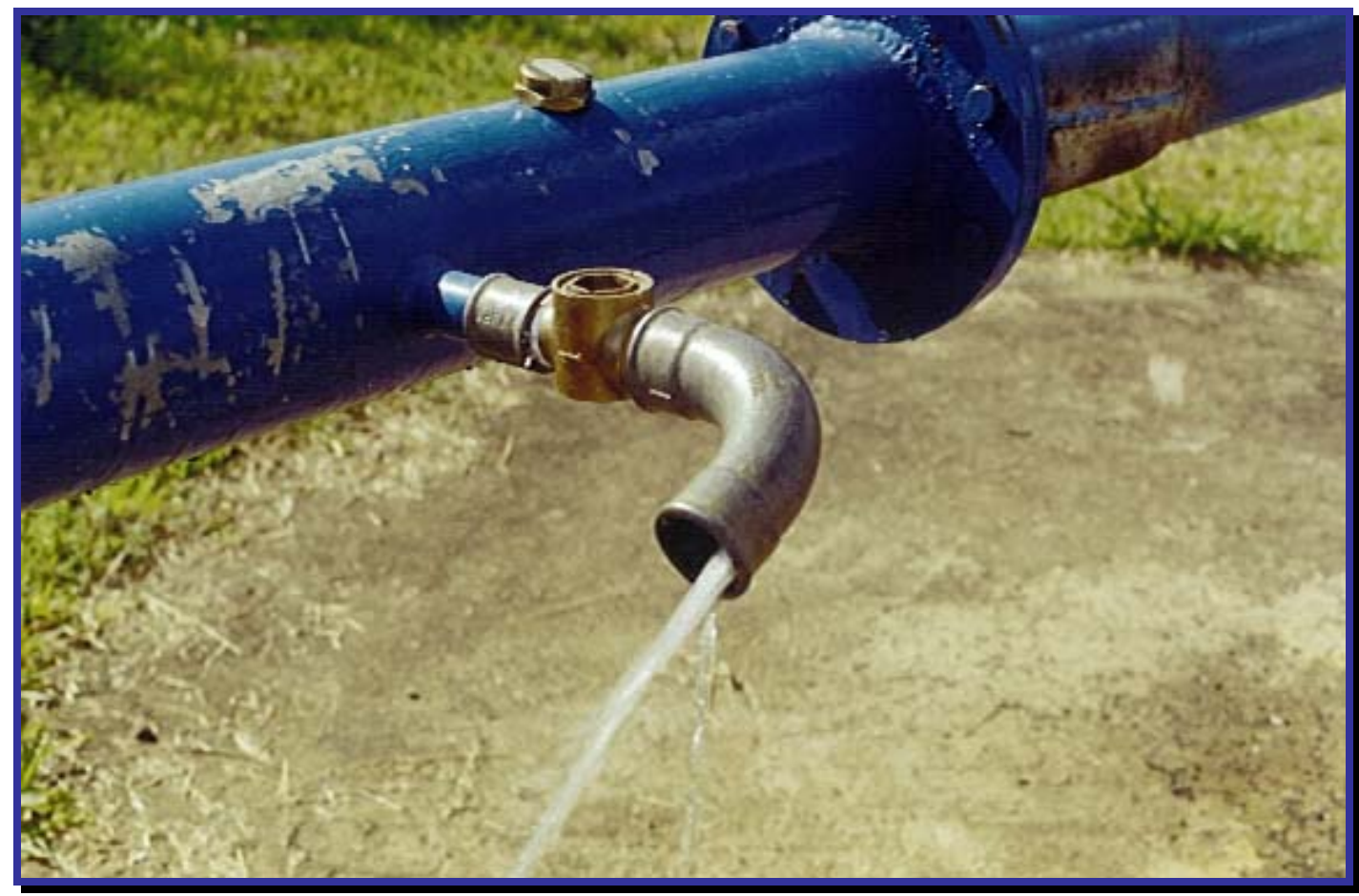

FIGURA 11 - Ponto de coletada de água na tubulação com água diretamente do poço, antes da fluoretação 


\section{Amostras das residências}

As amostras de água das residências, em todos os setores da cidade, foram coletadas por moradores no mesmo dia em que a pesquisadora estava realizando a coleta nos poços e na ETA. Estes moradores foram contatados previamente, questionados a respeito da sua disponibilidade e desejo em participar da pesquisa. Receberam a carta de informação e o Termo de Consentimento, conforme normas do Comitê de Ética em Pesquisa, e após a leitura, compreensão e assinatura do mesmo, passaram a fazer parte do grupo de voluntários para a coleta das amostras de água nas residências (APÊNDICE 2 e APÊNDICE 3). Este projeto de pesquisa foi submetido e aprovado pelo Comitê de Ética em Pesquisa da Faculdade de Odontologia de Bauru, FOB/USP (APÊNDICE 4). A seleção dos pontos de coleta dentro de cada um dos setores, foi feita com auxílio do mapa de setorização do abastecimento de água do município, como mencionado anteriormente. A definição dos participantes (pontos) da coleta foi por conveniência. Parte dos pontos foram estabelecidas utilizando uma listagem de funcionários da FOB/USP, com os endereços, disponibilizados pela Diretoria e, o restante, através de visita realizada pela pesquisadora em cada um dos setores estabelecendo contato com os moradores. Cerca de 20 funcionários da FOB/USP, participaram como voluntários na coleta das amostras.

Os responsáveis receberam um folheto informativo com as datas previstas para a coleta durante toda a pesquisa e a cada nova etapa, um folheto com as orientações quanto à forma de proceder à coleta e armazenagem da água (APÊNDICE 5). Além do folheto informativo com 
orientações de como realizar a coleta das amostras de água todos, foram orientados pessoalmente quanto a forma de proceder a coleta. As amostras eram guardadas na geladeira pelos voluntários.

Todos os frascos mais o folheto com as orientações para a coleta e um folheto informativo sobre saúde bucal eram colacados em um saco plástico maior, identificado com o nome do voluntário para facilitar a entrega dos mesmos. Os folhetos informativos sobre saúde bucal foram desenvolvidos pela pesquisadora com a finalidade de passar algumas informações gerais a respeito de saúde bucal para cerca de 300 pessoas (63 famílias) que participaram da pesquisa durante 1 ano. Nos folhetos foram abordados os seguintes temas (por ordem de entrega durante a pesquisa): A água que você bebe, sua saúde e a prevenção de cárie; Fluorose Dentária; A saúde da gestante e do seu bebê; Dieta, saúde geral e cárie dentária; A saúde geral e sua gengiva; Câncer de boca e o auto-exame (ANEXO 2, ANEXO 3, ANEXO 4, ANEXO 5, ANEXO 6 e ANEXO 7).

Em todas as etapas os voluntários receberam o material no final de semana anterior à semana da coleta (FIGURAS 12 e 13). Os participantes da pesquisa receberão os resultados das análises das amostras de água coletadas, quando também receberão explicações sobre os resultados. O DAE também receberá os resultados obtidos para que possa assim tomar as providências cabíveis. 


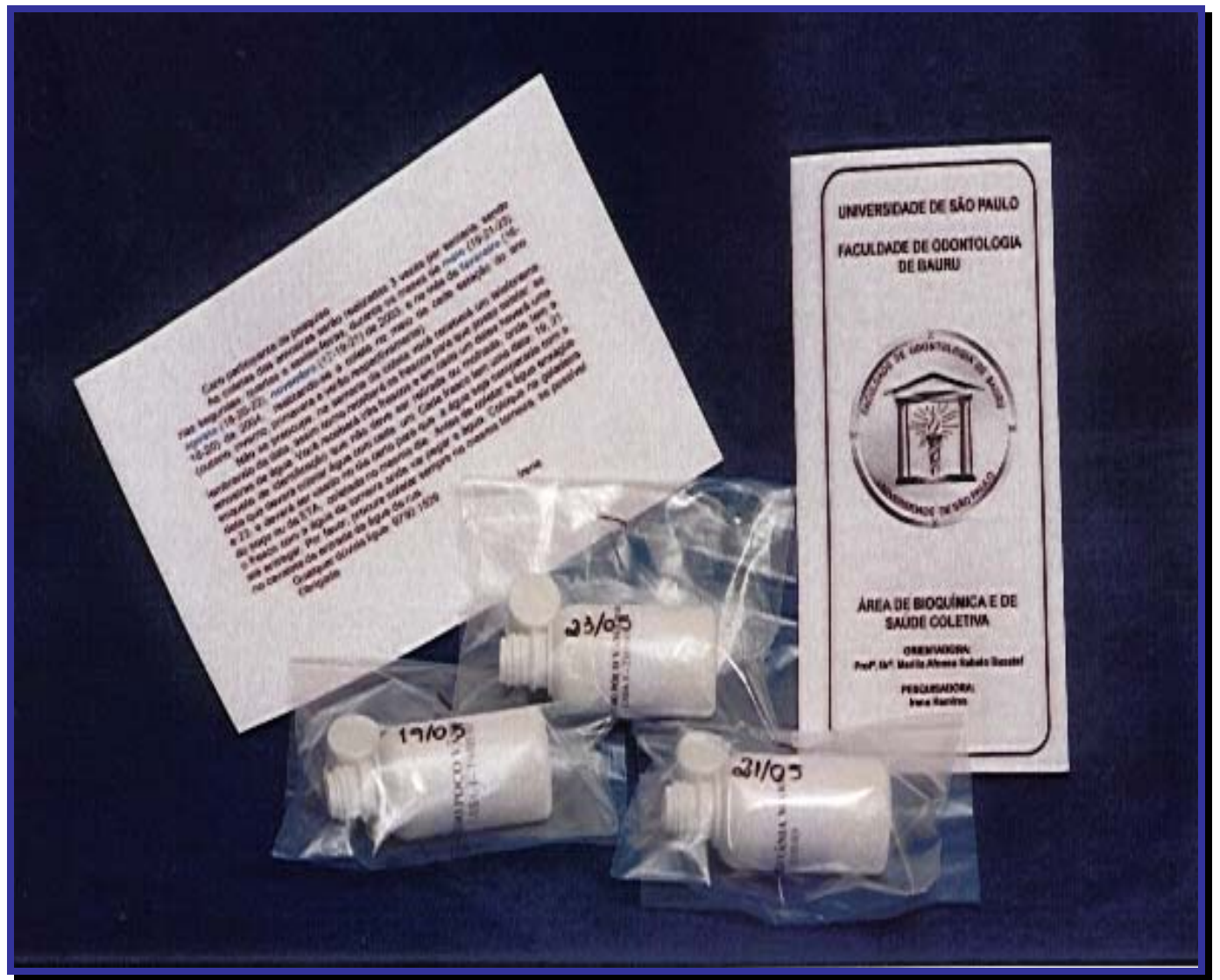

FIGURA 12 - Folheto informativo com as datas e orientações para proceder a coleta, folheto informativo com orientações de saúde bucal e os frascos para a coleta de água

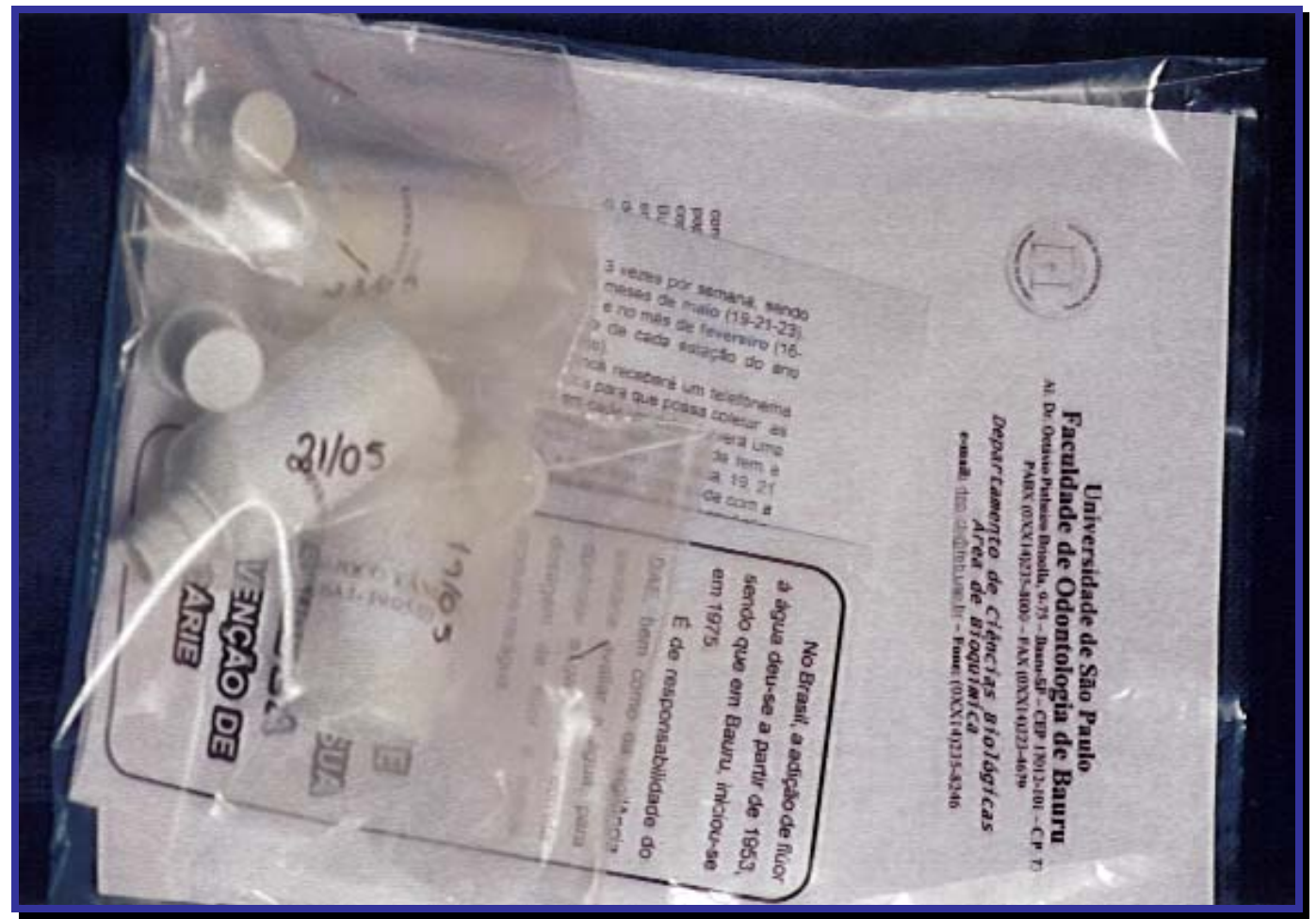

FIGURA 13 - Todo material entregue para os voluntários em cada uma das etapas da pesquisa 


\subsection{4 - Coleta das amostras}

Para a coleta das amostras de água foram utilizados frascos plásticos de $50 \mathrm{~mL}$, adquiridos especificamente para este fim, e, portanto, sem contato prévio com qualquer tipo de substância. Os frascos foram previamente etiquetados com a identificação do setor, número da casa, data e o nome do responsável pela coleta (FIGURA 14).

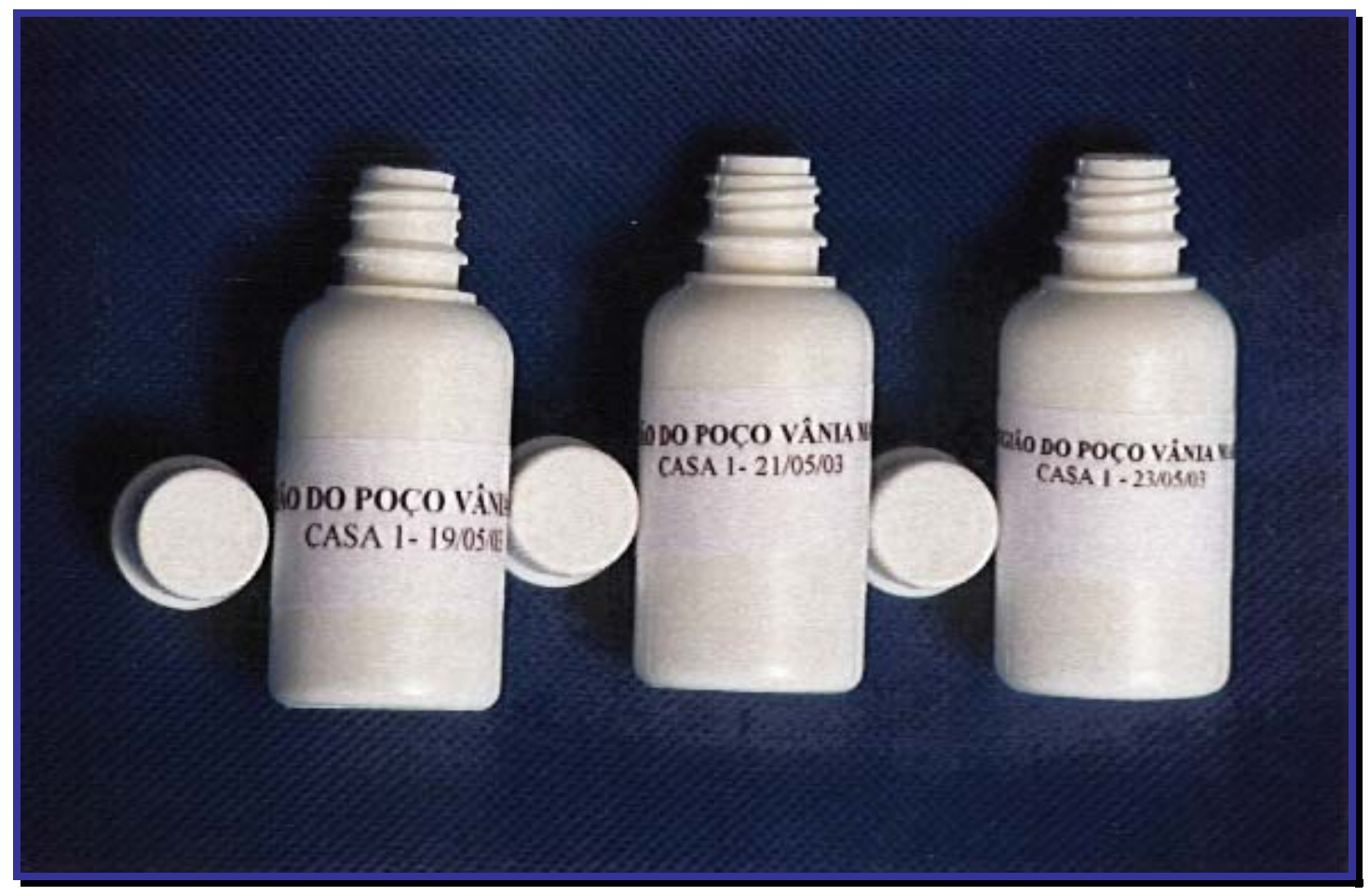

FIGURA 14 - Frascos plásticos de 50 mL usados para a coleta de água

Antes de proceder a coleta da amostra de água, os frascos eram enxaguados com a água a ser coletada, com a finalidade de condicionar o frasco. Os voluntários recebiam os frascos para as coletas das amostras dos três dias da semana dentro de um saco plástico individualizado para cada frasco. Este procedimento foi adotado com a finalidade de chamar a atenção dos voluntários para a data da coleta impressa nos sacos plásticos e nos frascos, para evitar erros na coleta. Optou-se por entregar os frascos nas 4 
etapas da pesquisa e não todos de uma única vez, para evitar transtornos no dia da coleta, como por exemplo a perda do frasco guardado por um longo período.

O recolhimento das amostras era feito pela pesquisadora no final de cada semana de coleta. As amostras assim que recolhidas, eram levadas para o laboratório de Bioquímica da $\mathrm{FOB}$, armazenadas na câmara à $-20^{\circ} \mathrm{C}$ e posteriormente analisadas.

\subsection{5 - Análise Bioquímica de F presente na água}

Método de leitura direta - Análise de F

A concentração de flúor presente nas amostras de água foi determinada em duplicata, utilizando-se o eletrodo íon sensível (Orion 9609), acoplado ao potenciômetro (Procyon, modelo 720), utilizando-se 1,0 mL da amostra à qual foi adicionado 1,0 $\mathrm{mL}$ de TISAB II (Orion). Para melhor entender o princípio da análise com eletrodo específico para flúor é importante saber que este método utiliza o potenciômetro ocoplado ao eletrodo, porque o potenciômetro acusa a diferença de potencial entre a solução contida dentro do eletrodo e a solução que está sendo analisada. Delta $V=-\log \left[\mathrm{F}^{-}\right]$. O pH ideal para a determinção da concentração de flúor é em torno de 5,0 a 5,5, pois $99 \%$ do flúor presente está ionizado e o eletrodo é sensível o flúor na forma iônica. Por isso, o pH do TISAB II, utilizado durante as análises é 5,0. A função do TISAB II é a de tamponar a amostra para a análise, bem como atuar como agente complexante, uma vez que o flúor pode se complexar com cálcio, alumínio e magnésio, acarretando 
distorção na dosagem. O TISAB II é um composto formado por: ácido acético Glacial, NaCl, CDTA (Sigma), NaOH (Nuclear).

Para a definição da curva foram utilizadas as seguintes soluções padrão: $0,1,0,2,0,4,0,8,1,6,3,2 \mathrm{mgF}$, preparadas a partir da solução padrão de 100 ppm F (Fluoride Standart). Foram realizados também, testes com concentrações conhecidas de flúor, a cada hora, para se checar a estabilidade da calibração do eletrodo. As leituras obtidas em $\mathrm{mV}$, foram convertidas para $\mu \mathrm{g}$ de $\mathrm{F}$, através do programa Excel (Microsoft). A média das leituras obtidas a partir dos padrões foi inserida na planilha, e então calculada a porcentagem de concordância, aceita até $90 \%$ para todos os padrões. O "slope" do eletrodo foi checado antes de cada uma das etapas de leitura. A checagem dos resultados das análises das amostras de água, foi feita através de nova leitura de 10\% das amostras (erro intraexaminador).

\subsubsection{Classificação das Amostras}

As amostras foram classificadas segundo o teor de flúor observado em cada trimestre (estação). O teor de flúor encontrado nas amostras foi utilizado para classificá-las como "aceitáveis" ou "inaceitáveis". De acordo com este critério, quando a amostra apresenta um teor de flúor entre 0,6 a 0,8 ppm (mg F/L) é considerada "aceitável" e "inaceitável", quando o teor de flúor está fora do intervalo estipulado. Estes critérios foram utilizados por NARVAI, em 2001 (TABELA 19) seguindo normas estabelecidas pela Secretaria Municipal de Saúde de São Paulo, baseadas na adaptação feita a partir de MINUGUCHI, 1972 (ARMONIA $\left.{ }^{4}, 1995\right)$. 
TABELA 19 - Classificação das amostras de água segundo a concentração de flúor*

\begin{tabular}{l|c}
\hline \multicolumn{1}{c}{ TEOR DE FLÚOR } & CLASSIFICAÇÃOICONCENTRAÇÃO \\
\hline Até $0,59 \mathrm{ppm}$ & Inaceitável \\
$0,60 \mathrm{ppm}$ & Mínima aceitável \\
$0,61 \mathrm{a} 0,69 \mathrm{ppm}$ & Sub-ótima \\
$0,70 \mathrm{ppm}$ & Ótima \\
0,71 a $0,79 \mathrm{ppm}$ & Supra-ótima \\
$0,80 \mathrm{ppm}$ & Máxima aceitável \\
0,81 a $1,19 \mathrm{ppm}$ & Inadequada \\
1,20 ppm & Limite \\
1,21 ppm ou mais & Inaceitável \\
\hline \multicolumn{2}{c}{ Fonte: SÃO PAULO (Município) } \\
\hline
\end{tabular}

Para a classificação das amostras obtidas com presente pesquisa foi elaborada uma tabela a partir da Tabela 19 e da descrita por Narvai $\left(\right.$ NARVAI $^{99}$, 2002), com a finalidade de facilitar a classificação das amostras dentro do intervalo de variação na concentração de flúor estabelecido pela legislação (SÃO PAULO $\left.{ }^{121}, 1995\right)$.

TABELA 20 - Classificação das amostras de água de acordo com a concentração de flúor em $\mathrm{mg} / \mathrm{L}^{*}$

\begin{tabular}{c|c}
\hline TEOR DE FLÚOR & CLASSIFICAÇÃo \\
\hline ㄷ $0,55 \mathrm{mg} / \mathrm{L}$ & Inaceitável (fator de proteção para cárie) \\
$\mathbf{0 , 5 5} \mathbf{~} \mathbf{g} / \mathbf{L}$ & Teor mínimo aceitável \\
$0,55 \vdash 0,65 \mathrm{mg} / \mathrm{L}$ & Sub-ótima \\
$0,65 \vdash 0,75 \mathrm{mg} / \mathrm{L}$ & Ótima \\
$0,75 \vdash 0,85 \mathrm{mg} / \mathrm{L}$ & Supra-ótima \\
$\mathbf{0 , 8 4} \mathbf{~} \mathbf{m g} / \mathbf{L}$ & Teor máximo aceitável \\
$0,85 \vdash 1,15 \mathrm{mg} / \mathrm{L}$ & Inadequada \\
$\mathbf{1 , 1 5}$ - ou mais mg/L & Inaceitável (fator de risco para fluorose) \\
\hline
\end{tabular}

* Fonte: Tabela adaptada e elaborada a partir de Narvai, 2002. 


\subsubsection{Análise dos dados obtidos}

Os dados obtidos trimestralmente, relativos ao teor de flúor na água foram analisados por meio de estatística descritiva, utilizando-se das médias que foram descritas por meio de tabelas e gráficos. 
5 Resultados 


\section{Resultados}

Os resultados da análise das amostras de água coletadas na ETA e nos poços antes da fluoretação, no período de maio de 2003 a fevereiro de 2004, estão apresentados nas TABELAS 21, 22, 23 e 24. Foram coletadas 318 amostras, das 336 previstas. Esta diferença entre o número de amostras idealmente estabelecido e o coletado é decorrente de fatores não previstos. No mês de maio o poço Garrafa não dispunha de um ponto para a coleta da amostra de água antes da fluoretação e o Santa Terezinha encontrava-se desativado (TABELA 21). No mês de agosto os mesmos fatores impossibilitaram a coleta das amostras de água destes dois poços (TABELA 22). Em novembro, no dia 17, os poços Parque Real I e Bíblia estavam com suas bombas temporariamente desligadas e no dia 19, a bomba do poço Lotes Urbanizados, também estava desligada (TABELA 23). Em fevereiro de 2004, o poço Nova Esperança foi desativado e o Lotes Urbanizados, no dia 18, estava com sua bomba desligada, o que impossibilitou a coleta das amostras de água (TABELA 24). Vale salientar que o setor normalmente abastecido pelo poço Nova Esperança, a partir do mês de fevereiro de 2004, teve seu abastecimento suprido pelos poços Distrito Industrial III, Roosevelt Il e Gasparini. A concentração média de flúor presente naturalmente na água da ETA e dos poços variou entre 0,05 (poço Garrafa) a 4,29 mg F/L (poço Bauru 25), sendo que esta última não corresponde ao valor real (flúor naturalmente presente na água). As considerações a respeito desta e outras constatações inesperadas, durante a análise das amostras, serão feitas na discussão. Ainda com relação à concentração de flúor naturalmente 
encontrado na água proveniente do manancial do Rio Batalha (ETA) e do Aqüífero Guarani (poços), não foram observadas alterações decorrentes de uma possível interferência das diferentes temperaturas e índices pluviométricos, nos meses de maio, agosto e novembro de 2003 e fevereiro de 2004, durante as quatro estações do ano (Tabela 25). Sempre considerando as condições de normalidade durante a coleta das amostras de água. O índice pluviométrico e as temperaturas do período foram informados pelo IPMET (ANEXO 4). A reprodutibilidade alcançada na análise das amostras foi de 98,84\%.

TABELA 21 - Concentração de flúor na água da ETA e dos poços antes da fluoretação, no mês de maio, em Bauru, 2003

\begin{tabular}{|c|c|c|c|c|c|}
\hline ETA e Poços & 19/mai & 21/mai & 23/mai & Média & $\mathbf{n}$ \\
\hline ETA & 0,11 & 0,09 & 0,08 & 0,09 & 3 \\
\hline Parque Real I & 1,44 & 1,58 & 1,28 & 1,43 & 3 \\
\hline Parque Real II & 0,14 & 0,12 & 0,17 & 0,14 & 3 \\
\hline Bauru 16 & 0,09 & 0,08 & 0,12 & 0,09 & 3 \\
\hline Nova Esperança & 0,08 & 0,07 & 0,11 & 0,08 & 3 \\
\hline Jaraguá & 0,12 & 0,11 & 0,15 & 0,12 & 3 \\
\hline Industrial III & 0,15 & 0,14 & 0,18 & 0,15 & 3 \\
\hline Roosevelt II & 0,11 & 0,11 & 0,11 & 0,11 & 3 \\
\hline Vânia Maria & 0,14 & 0,12 & 0,12 & 0,12 & 3 \\
\hline Bíblia & 0,11 & 0,09 & 0,09 & 0,09 & 3 \\
\hline Padilha & 0,10 & 0,09 & 0,09 & 0,09 & 3 \\
\hline Consolação & 0,13 & 0,10 & 0,10 & 0,11 & 3 \\
\hline Primavera & 0,11 & 0,10 & 0,10 & 0,10 & 3 \\
\hline Beija Flor & 0,11 & 0,11 & 0,11 & 0,11 & 3 \\
\hline Santa Cecília & 0,12 & 0,10 & 0,10 & 0,10 & 3 \\
\hline Garrafa* & -- & -- & -- & -- & 0 \\
\hline Gasparini & 0,13 & 0,11 & 0,11 & 0,11 & 3 \\
\hline Lotes Urbanizados & 0,12 & 0,10 & 0,11 & 0,11 & 3 \\
\hline Mary Dota & 0,11 & 0,07 & 0,10 & 0,09 & 3 \\
\hline Cruzeiro do Sul & 0,12 & 0,10 & 0,10 & 0,10 & 3 \\
\hline Octávio Rasi & 0,09 & 0,07 & 0,08 & 0,08 & 3 \\
\hline Funcraf & 0,08 & 0,09 & 0,07 & 0,08 & 3 \\
\hline Santa Terezinha** & -- & -- & -- & -- & 0 \\
\hline Bauru 25 & 0,11 & 0,10 & 0,09 & 0,10 & 3 \\
\hline Geisel II & 0,12 & 0,10 & 0,10 & 0,10 & 3 \\
\hline Nações & 0,13 & 0,10 & 0,10 & 0,11 & 3 \\
\hline Samambaia & 0,22 & 0,10 & 0,10 & 0,14 & 3 \\
\hline \multirow[t]{2}{*}{ Jardim América } & 0,12 & 0,09 & 0,09 & 0,10 & 3 \\
\hline & & & & Total & 78 \\
\hline
\end{tabular}

* O Poço Garrafa não tinha ponto disponível para coleta.

**O Poço Santa Terezinha estava desativado. 
TABELA 22 - Concentração de flúor na água da ETA e dos poços antes da fluoretação, no mês de agosto, em Bauru, 2003

\begin{tabular}{|c|c|c|c|c|c|}
\hline ETA e Poços & 18/ago & 20/ago & 22/ago & Média & $\mathbf{n}$ \\
\hline ETA & 0,10 & 0,08 & 0,08 & 0,09 & 3 \\
\hline Parque Real I & 0,87 & 0,92 & 1,24 & 1,01 & 3 \\
\hline Parque Real II & 0,11 & 0,10 & 0,10 & 0,10 & 3 \\
\hline Bauru 16 & 0,08 & 0,06 & 0,07 & 0,07 & 3 \\
\hline Nova Esperança & 0,08 & 0,06 & 0,06 & 0,07 & 3 \\
\hline Jaraguá & 0,11 & 0,09 & 0,10 & 0,10 & 3 \\
\hline Industrial III & 0,13 & 0,11 & 0,11 & 0,12 & 3 \\
\hline Roosevelt II & 0,11 & 0,09 & 0,09 & 0,10 & 3 \\
\hline Vânia Maria & 0,12 & 0,10 & 0,10 & 0,11 & 3 \\
\hline Bíblia & 0,09 & 0,08 & 0,08 & 0,08 & 3 \\
\hline Padilha & 0,09 & 0,08 & 0,08 & 0,08 & 3 \\
\hline Consolação & 0,12 & 0,09 & 0,10 & 0,10 & 3 \\
\hline Primavera & 0,11 & 0,09 & 0,09 & 0,10 & 3 \\
\hline Beija Flor & 0,11 & 0,09 & 0,09 & 0,10 & 3 \\
\hline Santa Cecília & 0,11 & 0,09 & 0,09 & 0,10 & 3 \\
\hline Garrafa* & -- & -- & -- & -- & 0 \\
\hline Gasparini & 0,11 & 0,09 & 0,10 & 0,10 & 3 \\
\hline Lotes Urbanizados & 0,09 & 0,09 & 0,08 & 0,09 & 3 \\
\hline Mary Dota & 0,11 & 0,09 & 0,08 & 0,09 & 3 \\
\hline Cruzeiro do Sul & 0,10 & 0,09 & 0,09 & 0,09 & 3 \\
\hline Octávio Rasi & 0,08 & 0,07 & 0,07 & 0,07 & 3 \\
\hline Funcraf & 0,07 & 0,06 & 0,06 & 0,06 & 3 \\
\hline Santa Terezinha ${ }^{\star \star}$ & -- & -- & -- & -- & 0 \\
\hline Bauru 25 & 0,10 & 0,08 & 0,08 & 0,09 & 3 \\
\hline Geisel II & 0,11 & 0,09 & 0,09 & 0,10 & 3 \\
\hline Nações & 0,11 & 0,09 & 0,09 & 0,10 & 3 \\
\hline Samambaia & 0,11 & 0,09 & 0,08 & 0,09 & 3 \\
\hline Jardim América & 0,10 & 0,08 & 0,08 & 0,09 & 3 \\
\hline
\end{tabular}

* O Poço Garrafa não tinha ponto de coleta de água antes da fluoretação.

** O Poço Santa Terezinha estava desativado. 
TABELA 23 - Concentração de flúor na água da ETA e dos poços antes da fluoretação, no mês de novembro, em Bauru, 2003

\begin{tabular}{|c|c|c|c|c|c|}
\hline ETA e Poços & 17 Inov & $19 /$ nov & $21 /$ nov & Média & $\mathbf{n}$ \\
\hline ETA & 0,09 & 0,09 & 0,10 & 0,09 & 3 \\
\hline Parque Real I & -- & 1,30 & 1,17 & 1,24 & 2 \\
\hline Parque Real II & 0,13 & 0,14 & 0,12 & 0,13 & 3 \\
\hline Bauru 16 & 0,08 & 0,08 & 2,29 & 0,82 & 3 \\
\hline Nova Esperança & 0,07 & 0,08 & 0,08 & 0,08 & 3 \\
\hline Jaraguá & 0,11 & 0,11 & 0,11 & 0,11 & 3 \\
\hline Industrial III & 0,14 & 0,13 & 0,14 & 0,14 & 3 \\
\hline Roosevelt II & 0,11 & 0,11 & 0,11 & 0,11 & 3 \\
\hline Vânia Maria & 0,12 & 0,12 & 0,12 & 0,12 & 3 \\
\hline Bíblia & -- & 0,09 & 0,09 & 0,09 & 2 \\
\hline Padilha & 0,09 & 0,08 & 0,09 & 0,09 & 3 \\
\hline Consolação & 0,11 & 0,11 & 0,11 & 0,11 & 3 \\
\hline Primavera & 0,11 & 0,10 & 0,11 & 0,11 & 3 \\
\hline Beija Flor & 0,10 & 0,10 & 0,10 & 0,10 & 3 \\
\hline Santa Cecília & 0,10 & 0,10 & 0,10 & 0,10 & 3 \\
\hline Garrafa & 0,10 & 0,04 & 0,04 & 0,06 & 3 \\
\hline Gasparini & 0,10 & 0,10 & 0,10 & 0,10 & 3 \\
\hline Lotes Urbanizados & 0,08 & -- & 0,08 & 0,08 & 2 \\
\hline Mary Dota & 0,09 & 0,09 & 0,09 & 0,09 & 3 \\
\hline Cruzeiro do Sul & 0,09 & 0,09 & 0,10 & 0,09 & 3 \\
\hline Octávio Rasi & 0,07 & 0,07 & 0,07 & 0,07 & 3 \\
\hline Funcraf & 0,08 & 0,06 & 0,06 & 0,07 & 3 \\
\hline Santa Terezinha* & 0,52 & 0,63 & 0,66 & 0,60 & 3 \\
\hline Bauru 25 & 0,08 & 0,08 & 0,08 & 0,08 & 3 \\
\hline Geisel II & 0,09 & 0,09 & 0,09 & 0,09 & 3 \\
\hline Nações & 0,10 & 0,10 & 0,10 & 0,10 & 3 \\
\hline Samambaia & 0,09 & 0,09 & 0,09 & 0,09 & 3 \\
\hline \multirow[t]{2}{*}{ Jardim América } & 0,08 & 0,08 & 0,08 & 0,08 & 3 \\
\hline & & & & Total & 81 \\
\hline
\end{tabular}


TABELA 24 - Concentração de flúor na água da ETA e dos poços, antes da fluoretação, no mês de fevereiro, em Bauru, 2004

\begin{tabular}{|c|c|c|c|c|c|}
\hline ETA e Poços & $16 / f e v$ & $18 / f e v$ & $20 / f e v$ & Média & $\mathbf{n}$ \\
\hline ETA & 0,12 & 0,11 & 0,10 & 0,11 & 3 \\
\hline Parque Real I & 0,94 & 1,18 & 6,68 & 2,93 & 3 \\
\hline Parque Real II & 0,11 & 0,11 & 3,48 & 1,23 & 3 \\
\hline Bauru 16 & 0,08 & 0,08 & 0,56 & 0,24 & 3 \\
\hline Nova Esperança & -- & -- & -- & -- & 0 \\
\hline Jaraguá & 0,11 & 0,10 & 0,10 & 0,10 & 3 \\
\hline Industrial III & 0,13 & 0,13 & 0,12 & 0,13 & 3 \\
\hline Roosevelt II & 0,11 & 0,11 & 0,10 & 0,11 & 3 \\
\hline Vânia Maria & 0,13 & 0,12 & 0,11 & 0,12 & 3 \\
\hline Bíblia & 0,10 & 0,09 & 0,09 & 0,09 & 3 \\
\hline Padilha & 0,12 & 0,11 & 0,11 & 0,11 & 3 \\
\hline Consolação & 0,10 & 0,09 & 0,09 & 0,09 & 3 \\
\hline Primavera & 0,12 & 0,11 & 0,11 & 0,11 & 3 \\
\hline Beija Flor & 0,11 & 0,10 & 0,10 & 0,10 & 3 \\
\hline Santa Cecília & 0,11 & 0,11 & 0,11 & 0,11 & 3 \\
\hline Garrafa & 0,06 & 0,05 & 0,05 & 0,05 & 3 \\
\hline Gasparini & 0,12 & 0,11 & 0,08 & 0,10 & 3 \\
\hline Lotes Urbanizados & 0,10 & -- & 0,08 & 0,09 & 2 \\
\hline Mary Dota & 0,11 & 0,09 & 0,09 & 0,10 & 3 \\
\hline Cruzeiro do Sul & 0,11 & 0,11 & 0,09 & 0,10 & 3 \\
\hline Octávio Rasi & 0,09 & 0,09 & 0,07 & 0,08 & 3 \\
\hline Funcraf & 0,08 & 0,08 & 0,06 & 0,07 & 3 \\
\hline Santa Terezinha & 0,85 & 0,77 & 0,83 & 0,82 & 3 \\
\hline Bauru 25 & 0,10 & 12,70 & 0,08 & 4,29 & 3 \\
\hline Geisel II & 0,11 & 0,08 & 0,09 & 0,09 & 3 \\
\hline Nações & 0,11 & 0,09 & 0,09 & 0,10 & 3 \\
\hline Samambaia & 0,11 & 0,09 & 0,09 & 0,10 & 3 \\
\hline \multirow[t]{2}{*}{ Jardim América } & 0,10 & 0,09 & 0,08 & 0,09 & 3 \\
\hline & & & & Total & 80 \\
\hline
\end{tabular}


TABELA 25 - Concentração de flúor na água da ETA e dos poços, antes da fluoretação, nos meses de maio, agosto e novembro de 2003 e fevereiro de 2004, em Bauru

\begin{tabular}{|c|c|c|c|c|c|c|}
\hline ETA e Poços & mai & Ago & nov & fev & Média & $\mathbf{n}$ \\
\hline ETA & 0,09 & 0,09 & 0,09 & 0,11 & 0,09 & 12 \\
\hline Parque Real I & 1,43 & 1,01 & 1,24 & 2,93 & 1,65 & 11 \\
\hline Parque Real II & 0,14 & 0,10 & 0,13 & 1,23 & 0,40 & 12 \\
\hline Bauru 16 & 0,09 & 0,07 & 0,82 & 0,24 & 0,30 & 12 \\
\hline Nova Esperança* & 0,08 & 0,07 & 0,08 & -- & 0,07 & 9 \\
\hline Jaraguá & 0,12 & 0,10 & 0,11 & 0,10 & 0,10 & 12 \\
\hline Industrial III & 0,15 & 0,12 & 0,14 & 0,13 & 0,13 & 12 \\
\hline Roosevelt II & 0,11 & 0,10 & 0,11 & 0,11 & 0,10 & 12 \\
\hline Vânia Maria & 0,12 & 0,11 & 0,12 & 0,12 & 0,11 & 12 \\
\hline Bíblia & 0,09 & 0,08 & 0,09 & 0,09 & 0,08 & 11 \\
\hline Padilha & 0,09 & 0,08 & 0,09 & 0,11 & 0,09 & 12 \\
\hline Consolação & 0,11 & 0,10 & 0,11 & 0,09 & 0,10 & 12 \\
\hline Primavera & 0,10 & 0,10 & 0,11 & 0,11 & 0,10 & 12 \\
\hline Beija Flor & 0,11 & 0,10 & 0,10 & 0,10 & 0,10 & 12 \\
\hline Cecília & 0,10 & 0,10 & 0,10 & 0,11 & 0,10 & 12 \\
\hline Garrafa** & - & -- & 0,06 & 0,05 & 0,05 & 6 \\
\hline Gasparini & 0,11 & 0,10 & 0,10 & 0,10 & 0,10 & 12 \\
\hline Lotes Urbanizados & 0,11 & 0,09 & 0,08 & 0,09 & 0,09 & 10 \\
\hline Mary Dota & 0,09 & 0,09 & 0,09 & 0,10 & 0,09 & 12 \\
\hline Cruzeiro do Sul & 0,10 & 0,09 & 0,09 & 0,10 & 0,09 & 12 \\
\hline Octávio Rasi & 0,08 & 0,07 & 0,07 & 0,08 & 0,07 & 12 \\
\hline Funcraf & 0,08 & 0,06 & 0,07 & 0,07 & 0,07 & 12 \\
\hline Santa Terezinha*** & -- & -- & 0,60 & 0,82 & 0,71 & 6 \\
\hline Bauru 25 & 0,10 & 0,09 & 0,08 & 4,29 & 1,14 & 12 \\
\hline Geisel II & 0,10 & 0,10 & 0,09 & 0,09 & 0,09 & 12 \\
\hline Nações & 0,11 & 0,10 & 0,10 & 0,10 & 0,10 & 12 \\
\hline Samambaia & 0,14 & 0,09 & 0,09 & 0,10 & 0,10 & 12 \\
\hline \multirow[t]{2}{*}{ Jardim América } & 0,10 & 0,09 & 0,08 & 0,09 & 0,09 & 12 \\
\hline & & & & & Total & 318 \\
\hline
\end{tabular}


Com relação às amostras de água coletadas na ETA e nos poços depois da fluoretação, de acordo com o projeto inicial deveriam ser coletadas 300 amostras, mas o total alcançado foi de 297, pelo fato do poço Nova Esperança encontrar-se desativado no mês de fevereiro (TABELA 32). O número de amostras de água coletadas nos poços, depois da fluoretação, é menor que o estabelecido para antes da fluoretação, uma vez que os poços Padilha/Consolação, Santa Cecília/Garrafa e Funcraf/Santa Terezinha, têm suas águas fluoretadas em um mesmo ponto, reduzindo assim, o número de amostras. A média da concentração de flúor adicionado artificialmente à água da ETA e dos poços, no período de maio de 2003 a fevereiro de 2004, variou entre 0,26 (poço Lotes Urbanizados, mês de maio) a 6,23 mg/L (poço Parque Real I, mês de fevereiro) (TABELAS 26, 28, 30 e 32). Durante a análise das amostras a reprodutibilidade resultante foi $98,85 \%$.

A classificação das amostras de água dos meses de maio, agosto, novembro de 2003 e de fevereiro de 2004, de acordo com a concentração de flúor, está apresentada nas tabelas 27, 29, 31 e 33, respectivamente. No mês de maio, cerca de $36 \%$ das amostras foram classificadas como inaceitáveis e, 61\%, entre a mínima e a máxima aceitável (TABELA 27). No mês de agosto, aproximadamente $68 \%$ das amostras de água, apresentaram uma concentração de flúor variando entre a mínima e a máxima aceitável, e 32 \% a concentração de flúor foi considerada inaceitável (TABELA 29). No entanto, em novembro cerca de $83 \%$ das amostras foram classificadas como dentro do limite mínimo e máximo aceitável (TABELA 31). Em fevereiro de 2004, $11 \%$ das amostras apresentaram uma 
concentração de flúor classificada como inaceitável e aproximadamente 88\% entre os limites de mínima e máxima aceitável, resultado inverso ao verificado no mês de agosto e próximo do verificado no mês de novembro (TABELA 33). Através das TABELAS 34 e 35 pode-se analisar a variação na média da concentração de flúor das 297 amostras coletadas na ETA e nos poços, durante todo o período de maio de 2003 a fevereiro de 2004, bem como a classificação destas amostras de acordo com a concentração de flúor. A menor média verificada para o período foi a do poço Lotes Urbanizados, 0,48 mg F/L, enquanto que a maior, foi a do poço Parque Real I, 2,85 mg F/L (TABELA 34). De acordo com a classificação, cerca de 22\% das amostras foram consideradas inaceitáveis, 3\% inadequadas e $75 \%$ variando entre os limites de mínima e máxima concentração aceitável (TABELA 35 e FIGURA 23). 
TABELA 26 - Concentração de flúor na água da ETA e dos poços depois da fluoretação, no mês de maio, em Bauru, 2003

\begin{tabular}{lccccc}
\hline \multicolumn{1}{c}{ ETA e Poços } & $\mathbf{1 9 / m a i}$ & $\mathbf{2 1 / m a i}$ & $\mathbf{2 3 / m a i}$ & Média & $\mathbf{n}$ \\
\hline ETA & 0,51 & 0,42 & 0,39 & $\mathbf{0 , 4 4}$ & 3 \\
Parque Real I & 1,62 & 2,51 & 0,98 & $\mathbf{1 , 7 0}$ & 3 \\
Parque Real II & 0,57 & 0,56 & 0,64 & $\mathbf{0 , 5 9}$ & 3 \\
Bauru 16 & 0,63 & 0,67 & 0,70 & $\mathbf{0 , 6 7}$ & 3 \\
Nova Esperança & 0,62 & 0,76 & 0,67 & $\mathbf{0 , 6 8}$ & 3 \\
Jaraguá & 0,75 & 0,74 & 0,54 & $\mathbf{0 , 6 8}$ & 3 \\
Industrial III & 1,23 & 0,79 & 0,84 & $\mathbf{0 , 9 5}$ & 3 \\
Roosevelt II & 0,61 & 0,60 & 0,54 & $\mathbf{0 , 5 8}$ & 3 \\
Vânia Maria & 0,68 & 0,54 & 0,65 & $\mathbf{0 , 6 2}$ & 3 \\
Bíblia & 0,48 & 0,53 & 0,53 & $\mathbf{0 , 5 1}$ & 3 \\
Padilha/Consolação & 0,43 & 0,42 & 0,41 & $\mathbf{0 , 4 2}$ & 3 \\
Primavera & 0,65 & 0,71 & 0,75 & $\mathbf{0 , 7 0}$ & 3 \\
Beija Flor & 0,39 & 0,41 & 0,72 & $\mathbf{0 , 5 1}$ & 3 \\
Santa Cecília/Garrafa & 0,64 & 0,74 & 0,66 & $\mathbf{0 , 6 8}$ & 3 \\
Gasparini & 0,63 & 0,63 & 0,65 & $\mathbf{0 , 6 4}$ & 3 \\
Lotes Urbanizados & 0,07 & 0,33 & 0,39 & $\mathbf{0 , 2 6}$ & 3 \\
Mary Dota & 0,10 & 0,77 & 0,78 & $\mathbf{0 , 5 5}$ & 3 \\
Cruzeiro do Sul & 0,55 & 0,63 & 0,58 & $\mathbf{0 , 5 9}$ & 3 \\
Octávio Rasi & 0,92 & 0,69 & 0,72 & $\mathbf{0 , 7 8}$ & 3 \\
Funcraf/Santa Terezinha & 0,55 & 0,57 & 0,57 & $\mathbf{0 , 5 6}$ & 3 \\
Bauru 25 & 0,70 & 0,57 & 0,51 & $\mathbf{0 , 5 9}$ & 3 \\
Geisel II & 0,72 & 0,61 & 0,55 & $\mathbf{0 , 6 3}$ & 3 \\
Nações & 0,65 & 0,56 & 0,54 & $\mathbf{0 , 5 8}$ & 3 \\
Samambaia & 0,49 & 0,44 & 0,45 & $\mathbf{0 , 4 6}$ & 3 \\
Jardim América & 0,66 & 0,52 & 0,55 & $\mathbf{0 , 5 8}$ & 3 \\
\hline & & & & $\mathbf{T o t a l}$ & $\mathbf{7 5}$ \\
\hline
\end{tabular}

TABELA 27 - Classificação das amostras de água da ETA e dos poços, de acordo com o teor de flúor, no mês de maio de 2003, em Bauru

\begin{tabular}{cccc}
\hline Teor de flúor & $\mathbf{n}$ & $\%$ & Classificação \\
\hline $0 \vdash-0,55 \mathrm{mg} / \mathrm{L}$ & 24 & 32 & Inaceitável \\
$0,55 \models-0,65 \mathrm{mg} / \mathrm{L}$ & 21 & 28 & Sub-ótima \\
$0,65 \models-75 \mathrm{mg} / \mathrm{L}$ & 18 & 24 & Ótima \\
$0,75 \models 0,85 \mathrm{mg} / \mathrm{L}$ & 7 & 9 & Supra-ótima \\
$0,85 \models-15 \mathrm{mg} / \mathrm{L}$ & 2 & 3 & Inadequada \\
$1,15 \models$ acima & 3 & 4 & Inaceitável \\
\hline Total & $\mathbf{7 5}$ & $\mathbf{1 0 0}$ & \\
\hline
\end{tabular}




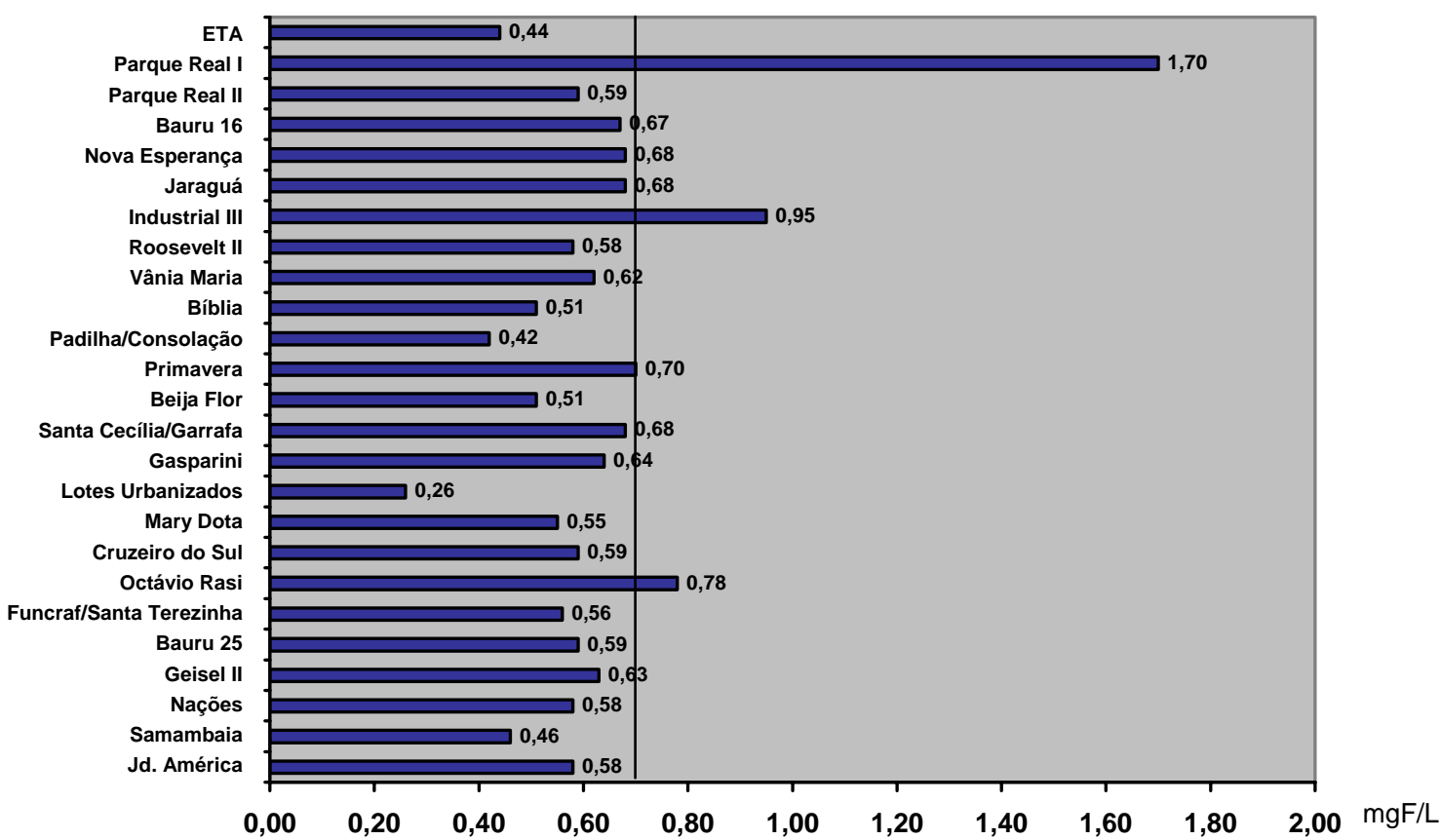

FIGURA 15 - Concentração média de flúor na ETA e nos poços, em Bauru no mês de maio de 2003

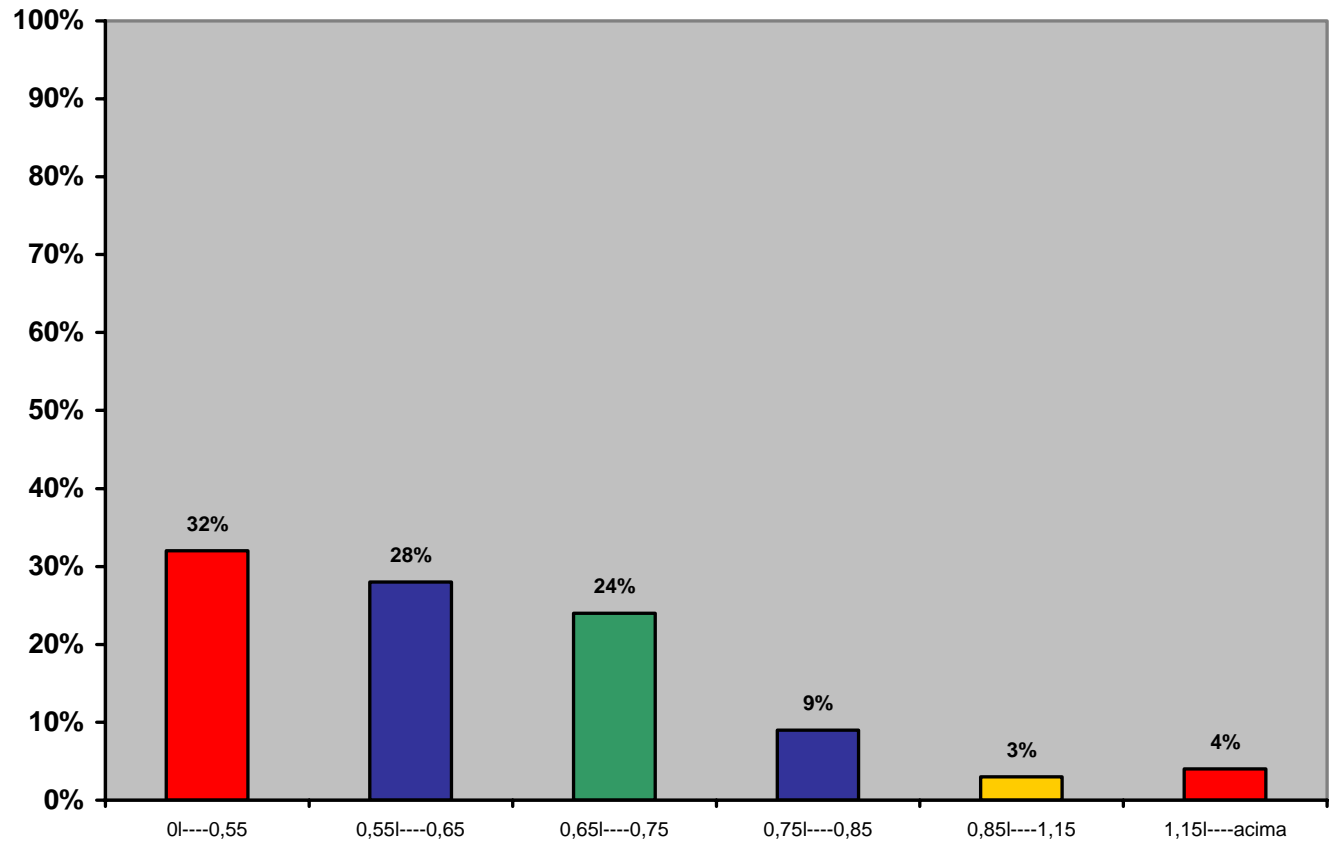

FIGURA 16 - Classificação das amostras de água de acordo com a concentração de flúor da ETA e dos poços de Bauru, no mês de maio de 2003 
TABELA 28 - Concentração de flúor na água da ETA e dos poços depois da fluoretação, no mês de agosto, em Bauru, 2003

\begin{tabular}{lccccc}
\hline ETA e Poços & $\mathbf{1 8 / a g o}$ & $\mathbf{2 0 / a g o}$ & $\mathbf{2 2 / a g o}$ & Média & $\mathbf{n}$ \\
\hline ETA & 0,53 & 0,47 & 0,51 & $\mathbf{0 , 5 0}$ & 3 \\
Parque Real I & 1,24 & 2,28 & 1,21 & $\mathbf{1 , 5 8}$ & 3 \\
Parque Real II & 0,54 & 0,56 & 0,45 & $\mathbf{0 , 5 2}$ & 3 \\
Bauru 16 & 0,60 & 0,62 & 0,57 & $\mathbf{0 , 6 0}$ & 3 \\
Nova Esperança & 0,56 & 0,59 & 0,49 & $\mathbf{0 , 5 5}$ & 3 \\
Jaraguá & 0,63 & 0,60 & 0,61 & $\mathbf{0 , 6 1}$ & 3 \\
Industrial III & 0,69 & 0,48 & 0,56 & $\mathbf{0 , 5 8}$ & 3 \\
Roosevelt II & 0,65 & 0,66 & 0,63 & $\mathbf{0 , 6 5}$ & 3 \\
Vânia Maria & 0,76 & 0,57 & 0,56 & $\mathbf{0 , 6 3}$ & 3 \\
Bíblia & 0,56 & 0,60 & 0,61 & $\mathbf{0 , 5 9}$ & 3 \\
Padilha/Consolação & 0,54 & 0,52 & 0,55 & $\mathbf{0 , 5 4}$ & 3 \\
Primavera & 0,51 & 0,54 & 0,54 & $\mathbf{0 , 5 3}$ & 3 \\
Beija Flor & 0,55 & 0,50 & 0,41 & $\mathbf{0 , 4 9}$ & 3 \\
SantaCecília/Garrafa & 0,42 & 0,42 & 0,25 & $\mathbf{0 , 3 6}$ & 3 \\
Gasparini & 0,55 & 0,55 & 0,63 & $\mathbf{0 , 5 8}$ & 3 \\
Lotes Urbanizados & 0,63 & 0,65 & 0,62 & $\mathbf{0 , 6 3}$ & 3 \\
Mary Dota & 0,63 & 0,59 & 0,60 & $\mathbf{0 , 6 1}$ & 3 \\
Cruzeiro do Sul & 0,58 & 0,56 & 0,62 & $\mathbf{0 , 5 9}$ & 3 \\
Octávio Rasi & 0,78 & 2,66 & 0,50 & $\mathbf{1 , 3 1}$ & 3 \\
Funcraf/Santa Terezinha* & 0,58 & 0,60 & 0,57 & $\mathbf{0 , 5 8}$ & 3 \\
Bauru 25 & 0,60 & 0,60 & 0,58 & $\mathbf{0 , 5 9}$ & 3 \\
Geisel II & 0,55 & 0,53 & 0,59 & $\mathbf{0 , 5 6}$ & 3 \\
Nações & 0,58 & 0,55 & 0,52 & $\mathbf{0 , 5 5}$ & 3 \\
Samambaia & 0,62 & 0,62 & 0,56 & $\mathbf{0 , 6 0}$ & 3 \\
Jardim América & 0,67 & 0,58 & 0,56 & $\mathbf{0 , 6 0}$ & 3 \\
\hline & & & & $\mathbf{T o t a l}$ & $\mathbf{7 5}$ \\
\hline Poço Santa Terezin & & & & &
\end{tabular}

* Poço Santa Terezinha desativado

TABELA 29 - Classificação das amostras de água da ETA e dos poços, de acordo com o teor de flúor, no mês de agosto de 2003, em Bauru

\begin{tabular}{cccc}
\hline Teor de flúor & $\mathbf{n}$ & $\%$ & Classificação \\
\hline $0 \vdash 0,55 \mathrm{mg} / \mathrm{L}$ & 20 & 27 & Inaceitável \\
$0,55 \models-0,65 \mathrm{mg} / \mathrm{L}$ & 44 & 58 & Sub-ótima \\
$0,65 \models 0,75 \mathrm{mg} / \mathrm{L}$ & 5 & 7 & Ótima \\
$0,75 \models 0,85 \mathrm{mg} / \mathrm{L}$ & 2 & 3 & Supra-ótima \\
$0,85 \models-15 \mathrm{mg} / \mathrm{L}$ & 0 & 0 & Inadequada \\
$1,15 \models$ acima & 4 & 5 & Inaceitável \\
\hline Total & $\mathbf{7 5}$ & $\mathbf{1 0 0}$ & \\
\hline
\end{tabular}




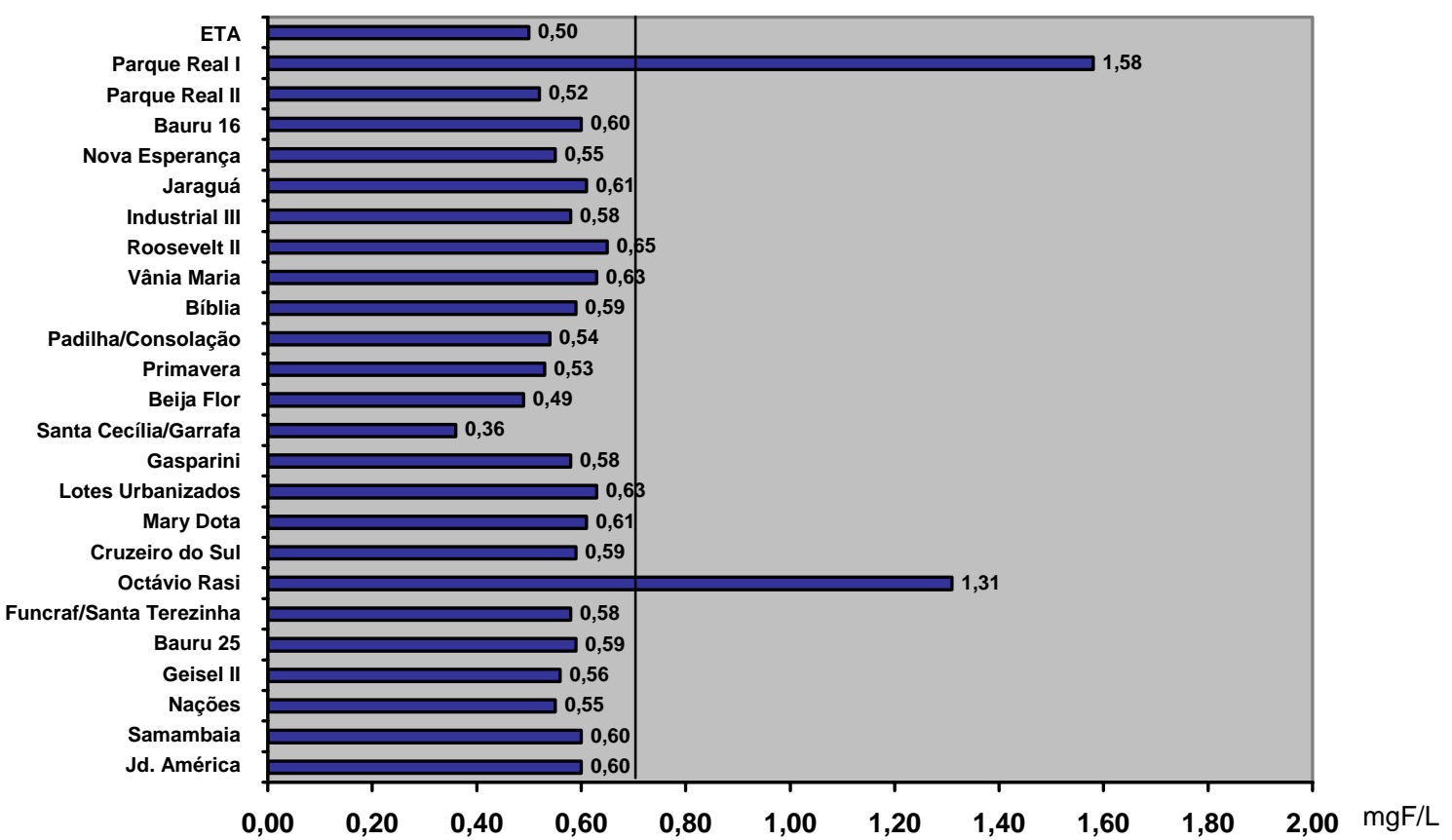

FIGURA 17 - Concentração média de flúor na ETA e nos poços, em Bauru no mês de agosto de 2003

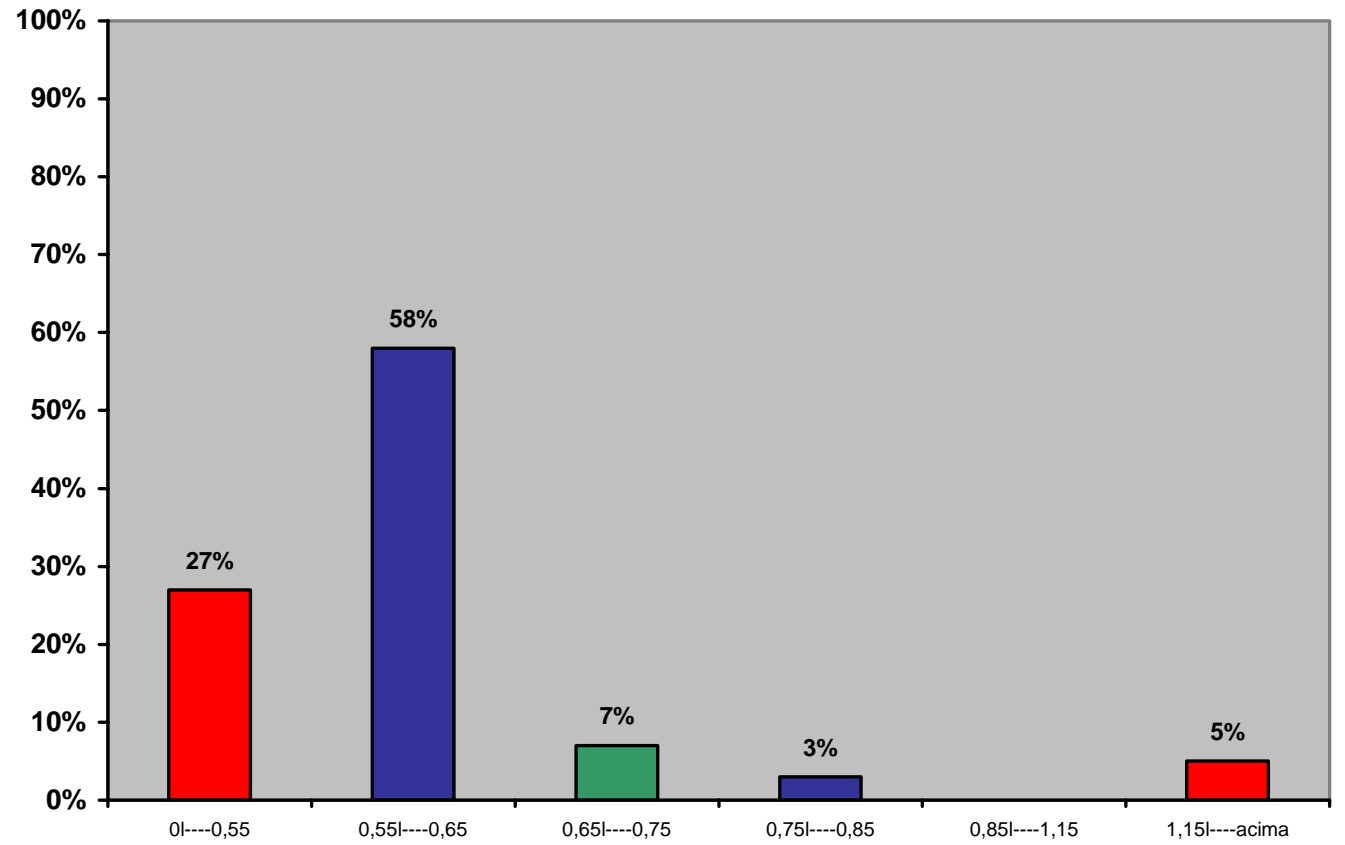

FIGURA 18 - Classificação das amostras de água de acordo com a concentração de flúor da ETA e dos poços de Bauru, no mês de agosto de 2003 
TABELA 30 - Concentração de flúor na água da ETA e dos poços depois da fluoretação, no mês de novembro, em Bauru, 2003

\begin{tabular}{lccccc}
\hline \multicolumn{1}{c}{ ETA e Poços } & $\mathbf{1 7 / n o v}$ & $\mathbf{1 9 / n o v}$ & $\mathbf{2 1 / n o v}$ & Média & $\mathbf{n}$ \\
\hline ETA & 0,79 & 0,77 & 0,80 & $\mathbf{0 , 7 9}$ & 3 \\
Parque Real I & 2,09 & 1,98 & 1,61 & $\mathbf{1 , 8 9}$ & 3 \\
Parque Real II & 0,77 & 0,70 & 0,67 & $\mathbf{0 , 7 1}$ & 3 \\
Bauru 16 & 0,73 & 0,73 & 0,73 & $\mathbf{0 , 7 3}$ & 3 \\
Nova Esperança & 0,74 & 0,86 & 0,77 & $\mathbf{0 , 7 9}$ & 3 \\
Jaraguá & 0,68 & 0,91 & 0,70 & $\mathbf{0 , 7 6}$ & 3 \\
Industrial III & 0,69 & 0,74 & 0,74 & $\mathbf{0 , 7 2}$ & 3 \\
Roosevelt II & 0,84 & 0,84 & 0,81 & $\mathbf{0 , 8 3}$ & 3 \\
Vânia Maria & 0,93 & 0,79 & 0,78 & $\mathbf{0 , 8 3}$ & 3 \\
Bíblia & 0,74 & 0,72 & 0,76 & $\mathbf{0 , 7 4}$ & 3 \\
Padilha/Consolação & 0,74 & 0,69 & 0,71 & $\mathbf{0 , 7 1}$ & 3 \\
Primavera & 0,77 & 0,78 & 0,78 & $\mathbf{0 , 7 8}$ & 3 \\
Beija Flor & 0,78 & 0,80 & 0,88 & $\mathbf{0 , 8 2}$ & 3 \\
Santa Cecília/Garrafa & 0,72 & 0,77 & 0,72 & $\mathbf{0 , 7 4}$ & 3 \\
Gasparini & 0,76 & 0,83 & 0,83 & $\mathbf{0 , 8 1}$ & 3 \\
Lotes Urbanizados & 0,43 & 0,51 & 0,61 & $\mathbf{0 , 5 2}$ & 3 \\
Mary Dota & 0,75 & 0,76 & 0,78 & $\mathbf{0 , 7 6}$ & 3 \\
Cruzeiro do Sul & 0,78 & 0,74 & 0,77 & $\mathbf{0 , 7 6}$ & 3 \\
Octávio Rasi & 0,81 & 0,89 & 0,86 & $\mathbf{0 , 8 5}$ & 3 \\
Funcraf/Sta Terezinha* & 0,63 & 0,64 & 0,65 & $\mathbf{0 , 6 4}$ & 3 \\
Bauru 25 & 0,85 & 0,78 & 1,15 & $\mathbf{0 , 9 3}$ & 3 \\
Geisel II & 0,73 & 0,70 & 0,73 & $\mathbf{0 , 7 2}$ & 3 \\
Nações & 0,69 & 0,78 & 0,75 & $\mathbf{0 , 7 4}$ & 3 \\
Samambaia & 0,74 & 0,74 & 0,74 & $\mathbf{0 , 7 4}$ & 3 \\
Jardim América & 0,76 & 0,79 & 0,76 & $\mathbf{0 , 7 7}$ & 3 \\
\hline & & & & $\mathbf{0 0 t a l}$ & $\mathbf{7 5}$ \\
\hline
\end{tabular}

* Poço Santa Terezinha reativado

TABELA 31 - Classificação das amostras de água da ETA e dos poços, de acordo com o teor de flúor, no mês de novembro de 2003, em Bauru

\begin{tabular}{cccc}
\hline Teor de flúor & $\mathbf{n}$ & $\%$ & Classificação \\
\hline O־ $0,55 \mathrm{mg} / \mathrm{L}$ & 2 & 3 & Inaceitável \\
$0,55 \models 0,65 \mathrm{mg} / \mathrm{L}$ & 3 & 4 & Sub-ótima \\
$0,65-0,75 \mathrm{mg} / \mathrm{L}$ & 27 & 36 & Ótima \\
$0,75 \models 0,85 \mathrm{mg} / \mathrm{L}$ & 32 & 43 & Supra-ótima \\
$0,85 \models-1,15 \mathrm{mg} / \mathrm{L}$ & 7 & 9 & Inadequada \\
$1,15 \models$ acima & 4 & 5 & Inaceitável \\
\hline Total & $\mathbf{7 5}$ & $\mathbf{1 0 0}$ & \\
\hline
\end{tabular}




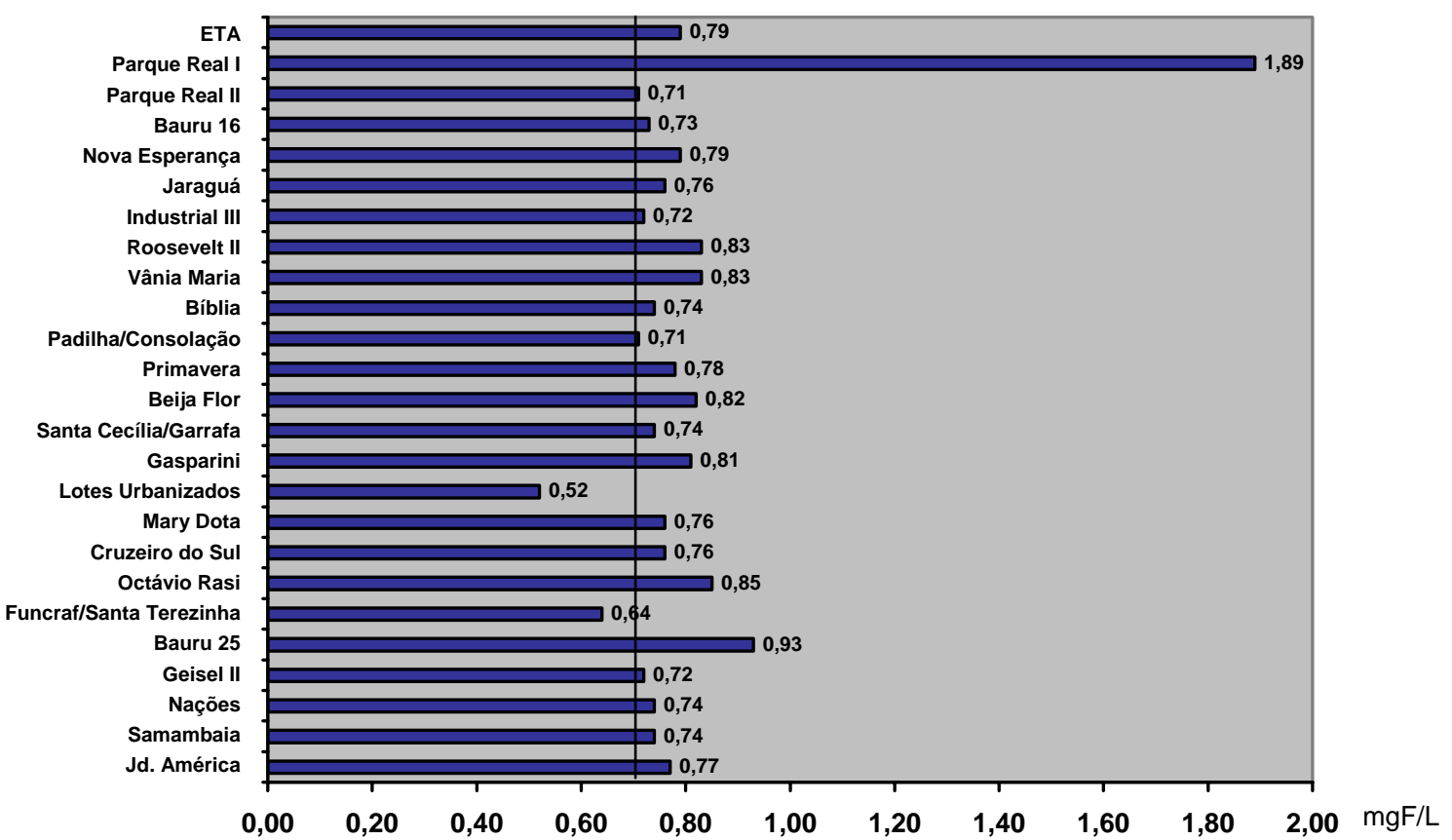

FIGURA 19 - Concentração média de flúor na ETA e nos poços, em Bauru no mês de novembro de 2003

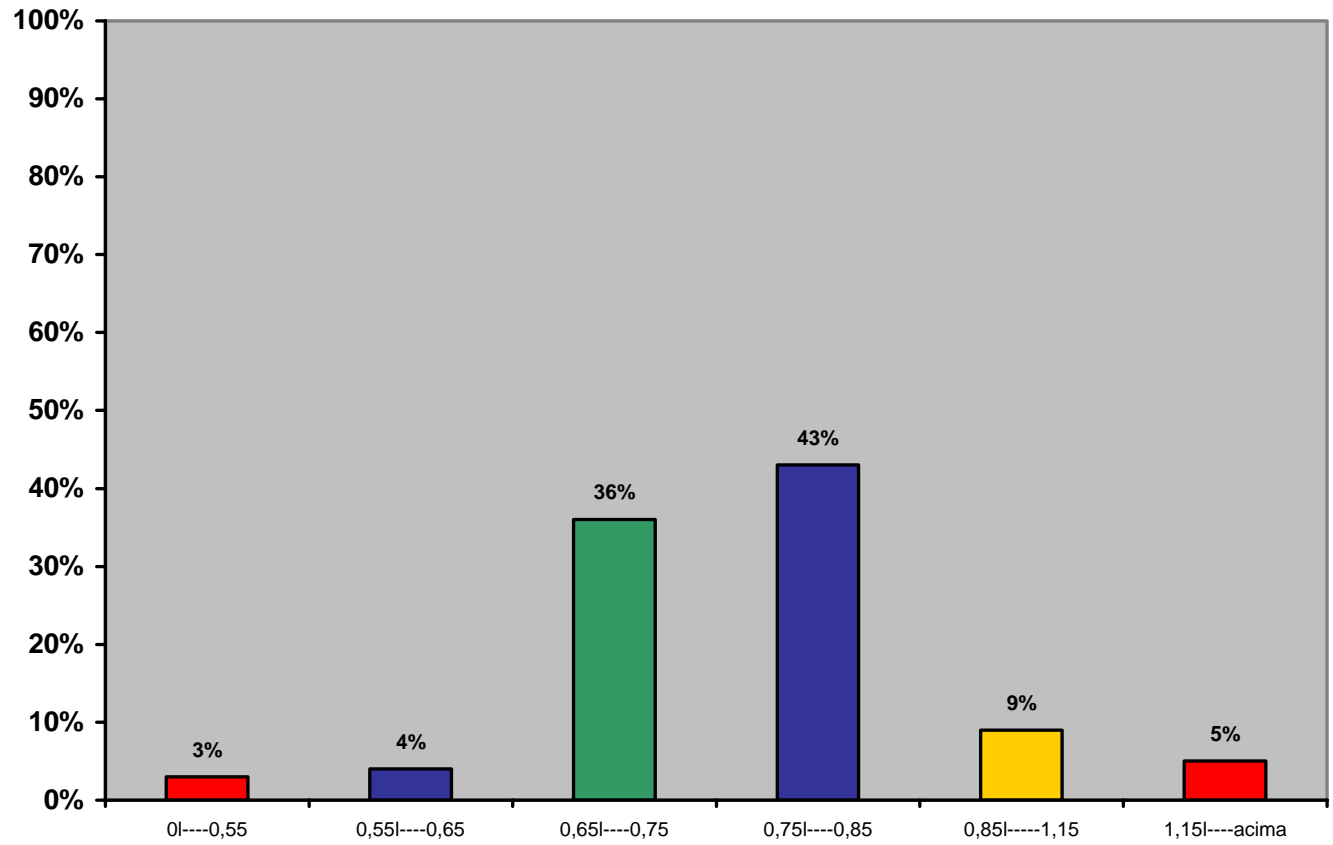

FIGURA 20 - Classificação das amostras de água de acordo com a concentração de flúor da ETA e dos poços de Bauru, no mês de novembro de 2003 
TABELA 32 - Concentração de flúor na água da ETA e dos poços depois da fluoretação, no mês de fevereiro, em Bauru, 2004

\begin{tabular}{lccccc}
\hline \multicolumn{1}{c}{ ETA e Poços } & $\mathbf{1 6 / f e v}$ & $\mathbf{1 8 / f e v}$ & $\mathbf{2 0 / f e v}$ & Média & $\mathbf{n}$ \\
\hline ETA & 0,58 & 0,63 & 0,59 & $\mathbf{0 , 6 0}$ & 3 \\
Parque Real I & 1,50 & 0,89 & 16,30 & $\mathbf{6 , 2 3}$ & 3 \\
Parque Real II & 0,67 & 0,63 & 0,61 & $\mathbf{0 , 6 4}$ & 3 \\
Bauru 16 & 0,68 & 0,62 & 0,63 & $\mathbf{0 , 6 4}$ & 3 \\
Nova Esperança* & -- & -- & -- & -- & \\
Jaraguá & 0,59 & 0,61 & 0,67 & $\mathbf{0 , 6 2}$ & 3 \\
Industrial III & 0,54 & 0,58 & 0,60 & $\mathbf{0 , 5 7}$ & 3 \\
Roosevelt II & 0,61 & 0,61 & 0,60 & $\mathbf{0 , 6 1}$ & 3 \\
Vânia Maria & 0,72 & 0,59 & 0,62 & $\mathbf{0 , 6 4}$ & 3 \\
Bíblia & 0,62 & 0,66 & 0,75 & $\mathbf{0 , 6 8}$ & 3 \\
Padilha/Consolação & 0,66 & 0,66 & 0,71 & $\mathbf{0 , 6 8}$ & 3 \\
Primavera & 0,59 & 0,59 & 0,59 & $\mathbf{0 , 5 9}$ & 3 \\
Beija Flor & 0,57 & 0,58 & 0,60 & $\mathbf{0 , 5 8}$ & 3 \\
Santa Cecília/Garrafa & 0,54 & 0,57 & 0,59 & $\mathbf{0 , 5 7}$ & 3 \\
Gasparini & 0,73 & 0,64 & 0,66 & $\mathbf{0 , 6 8}$ & 3 \\
Lotes Urbanizados & 0,11 & 0,60 & 0,77 & $\mathbf{0 , 4 9}$ & 3 \\
Mary Dota & 0,59 & 0,57 & 0,60 & $\mathbf{0 , 5 9}$ & 3 \\
Cruzeiro do Sul & 0,10 & 0,59 & 0,54 & $\mathbf{0 , 4 1}$ & 3 \\
Octávio Rasi & 0,72 & 0,69 & 0,67 & $\mathbf{0 , 6 9}$ & 3 \\
Funcraf/Sta Terezinha & 0,68 & 0,67 & 0,64 & $\mathbf{0 , 6 6}$ & 3 \\
Bauru 25 & 0,73 & 0,71 & 0,61 & $\mathbf{0 , 6 8}$ & 3 \\
Geisel II & 0,60 & 0,55 & 0,51 & $\mathbf{0 , 5 5}$ & 3 \\
Nações & 0,65 & 0,64 & 0,61 & $\mathbf{0 , 6 3}$ & $\mathbf{3}$ \\
Samambaia & 0,61 & 0,62 & 0,61 & $\mathbf{0 , 6 1}$ & $\mathbf{3}$ \\
Jardim América & 0,65 & 0,60 & 0,56 & $\mathbf{0 , 6 0}$ & $\mathbf{3}$ \\
\hline & & & & $\mathbf{T o t a l}$ & $\mathbf{7 2}$ \\
\hline
\end{tabular}

* Poço Nova Esperança desativado

TABELA 33 - Classificação das amostras de água da ETA e dos poços, de acordo com o teor de flúor, no mês de fevereiro de 2004, em Bauru

\begin{tabular}{rccc}
\hline Teor de flúor & $\mathbf{n}$ & $\%$ & Classificação \\
\hline $01-0,55 \mathrm{mg} / \mathrm{L}$ & 6 & 8 & Inaceitável \\
$0,55-0,65 \mathrm{mg} / \mathrm{L}$ & 42 & 59 & Sub-ótima \\
$0,65-0,75 \mathrm{mg} / \mathrm{L}$ & 19 & 26 & Ótima \\
$0,75-0,85 \mathrm{mg} / \mathrm{L}$ & 2 & 3 & Supra-ótima \\
$0,85-1,15 \mathrm{mg} / \mathrm{L}$ & 1 & 1 & Inadequada \\
$1,15-$ acima & 2 & 3 & Inaceitável \\
\hline Total & $\mathbf{7 2}$ & $\mathbf{1 0 0}$ & \\
\hline
\end{tabular}




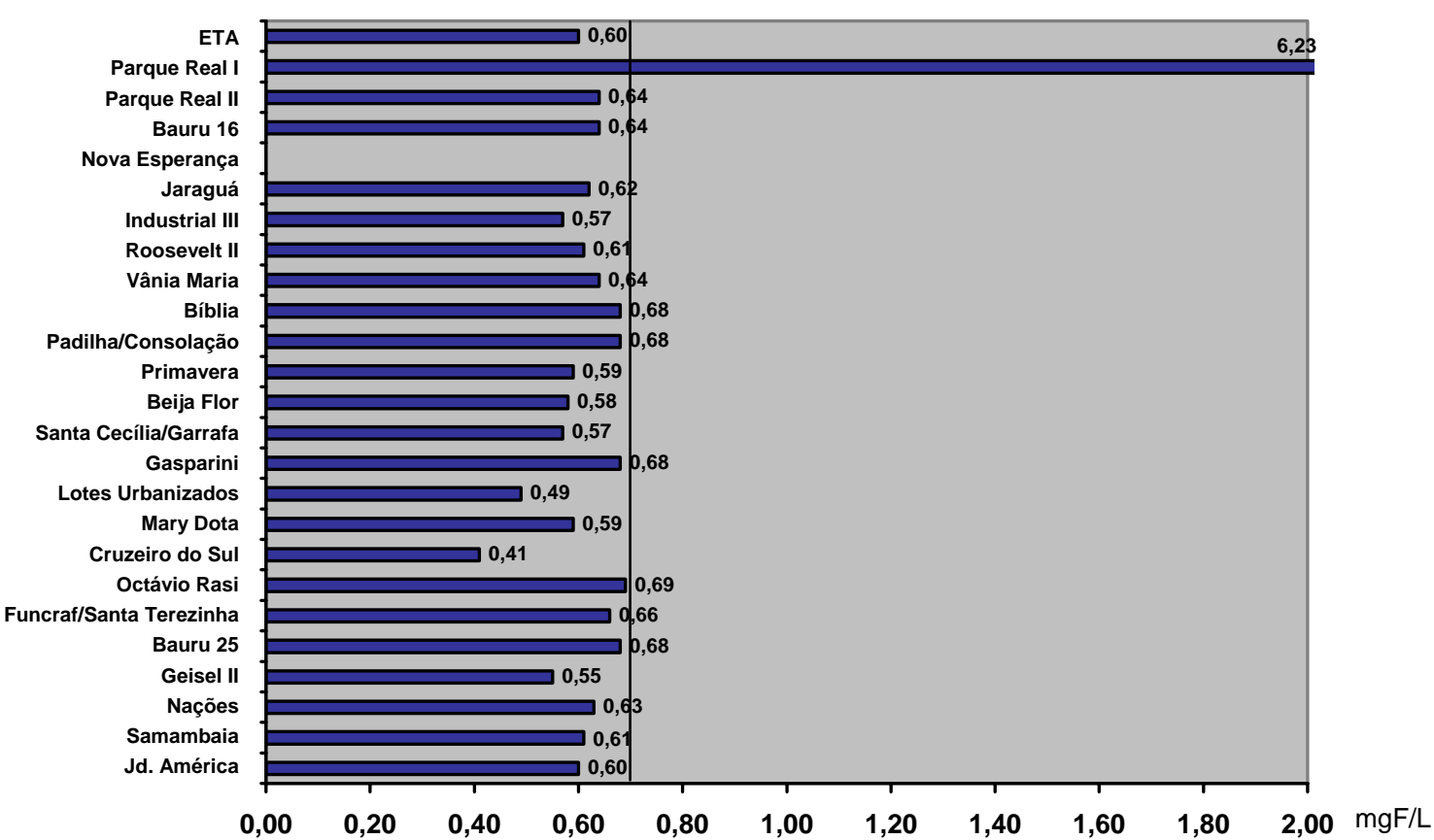

FIGURA 21 - Concentração média de flúor na ETA e nos poços, em Bauru no mês de fevereiro de 2004

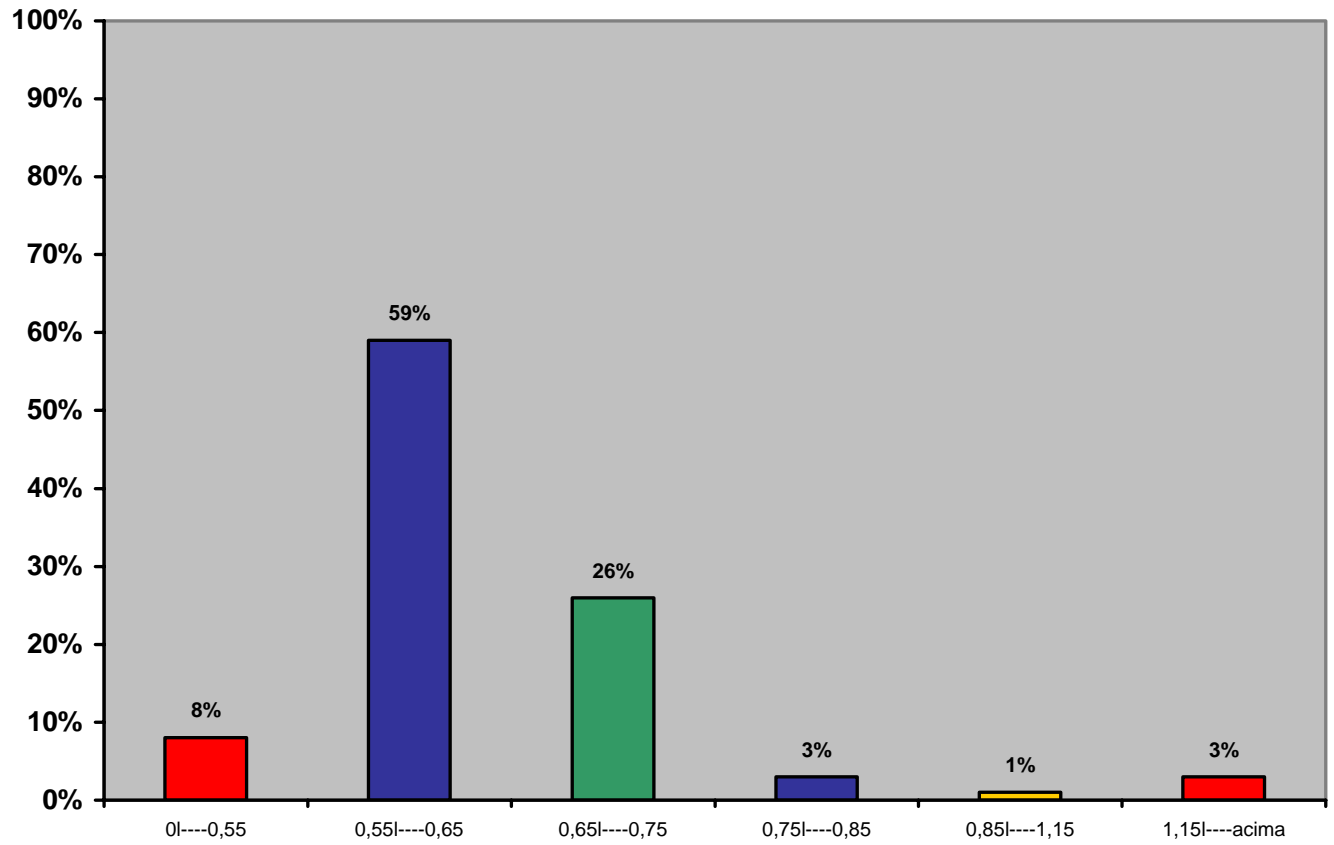

FIGURA 22 - Classificação das amostras de água de acordo com a concentração de flúor da ETA e dos poços de Bauru, no mês de fevereiro de 2004 
TABELA 34 - Concentração de flúor na água da ETA e dos poços, depois da fluoretação, nos meses de maio, agosto e novembro de 2003 e de fevereiro de 2004, em Bauru

\begin{tabular}{|c|c|c|c|c|c|c|}
\hline ETA e Poços & mai & ago & nov & fev & Média & $\mathbf{n}$ \\
\hline ETA & 0,44 & 0,50 & 0,79 & 0,60 & 0,58 & 12 \\
\hline Parque Real I & 1,70 & 1,58 & 1,89 & 6,23 & 2,85 & 12 \\
\hline Parque Real II & 0,59 & 0,52 & 0,71 & 0,64 & 0,62 & 12 \\
\hline Bauru 16 & 0,67 & 0,60 & 0,73 & 0,64 & 0,66 & 12 \\
\hline Nova Esperança* & 0,68 & 0,55 & 0,79 & -- & 0,67 & 9 \\
\hline Jaraguá & 0,68 & 0,61 & 0,76 & 0,62 & 0,67 & 12 \\
\hline Industrial III & 0,95 & 0,58 & 0,72 & 0,57 & 0,71 & 12 \\
\hline Roosevelt II & 0,58 & 0,65 & 0,83 & 0,61 & 0,67 & 12 \\
\hline Vânia Maria & 0,62 & 0,63 & 0,83 & 0,64 & 0,68 & 12 \\
\hline Bíblia & 0,51 & 0,59 & 0,74 & 0,68 & 0,63 & 12 \\
\hline Padilha/Consolação & 0,42 & 0,54 & 0,71 & 0,68 & 0,59 & 12 \\
\hline Primavera & 0,70 & 0,53 & 0,78 & 0,59 & 0,65 & 12 \\
\hline Beija Flor & 0,51 & 0,49 & 0,82 & 0,58 & 0,60 & 12 \\
\hline Santa Cecília/Garrafa & 0,68 & 0,36 & 0,74 & 0,57 & 0,59 & 12 \\
\hline Gasparini & 0,64 & 0,58 & 0,81 & 0,68 & 0,68 & 12 \\
\hline Lotes Urbanizados & 0,26 & 0,63 & 0,52 & 0,49 & 0,48 & 12 \\
\hline Mary Dota & 0,55 & 0,61 & 0,76 & 0,59 & 0,63 & 12 \\
\hline Cruzeiro do Sul & 0,59 & 0,59 & 0,76 & 0,41 & 0,59 & 12 \\
\hline Octávio Rasi & 0,78 & 1,31 & 0,85 & 0,69 & 0,91 & 12 \\
\hline Funcraf/Sta. Terezinha** & 0,56 & 0,58 & 0,64 & 0,66 & 0,61 & 12 \\
\hline Bauru 25 & 0,59 & 0,59 & 0,93 & 0,68 & 0,70 & 12 \\
\hline Geisel II & 0,63 & 0,56 & 0,72 & 0,55 & 0,62 & 12 \\
\hline Nações & 0,58 & 0,55 & 0,74 & 0,63 & 0,63 & 12 \\
\hline Samambaia & 0,46 & 0,60 & 0,74 & 0,61 & 0,60 & 12 \\
\hline \multirow[t]{2}{*}{ Jardim América } & 0,58 & 0,60 & 0,77 & 0,60 & 0,64 & 12 \\
\hline & & & & & Total & 297 \\
\hline
\end{tabular}

TABELA 35 - Classificação das amostras de água da ETA e dos poços, de acordo com o teor de flúor, nos meses de maio, agosto e novembro de 2003 e de fevereiro de 2004, em Bauru

\begin{tabular}{rccc}
\hline Teor de flúor & $\mathbf{n}$ & $\%$ & Classificação \\
\hline $01-0,55 \mathrm{mg} / \mathrm{L}$ & 52 & 18 & Inaceitável \\
$0,55 \models-0,65 \mathrm{mg} / \mathrm{L}$ & 110 & 37 & Sub-ótima \\
$0,65-0,75 \mathrm{mg} / \mathrm{L}$ & 69 & 23 & Ótima \\
$0,75-0,85 \mathrm{mg} / \mathrm{L}$ & 43 & 15 & Supra-ótima \\
$0,85 \models-15 \mathrm{mg} / \mathrm{L}$ & 10 & 3 & Inadequada \\
$1,15 \models$ acima & 13 & 4 & Inaceitável \\
\hline Total & $\mathbf{2 9 7}$ & $\mathbf{1 0 0}$ & \\
\hline
\end{tabular}




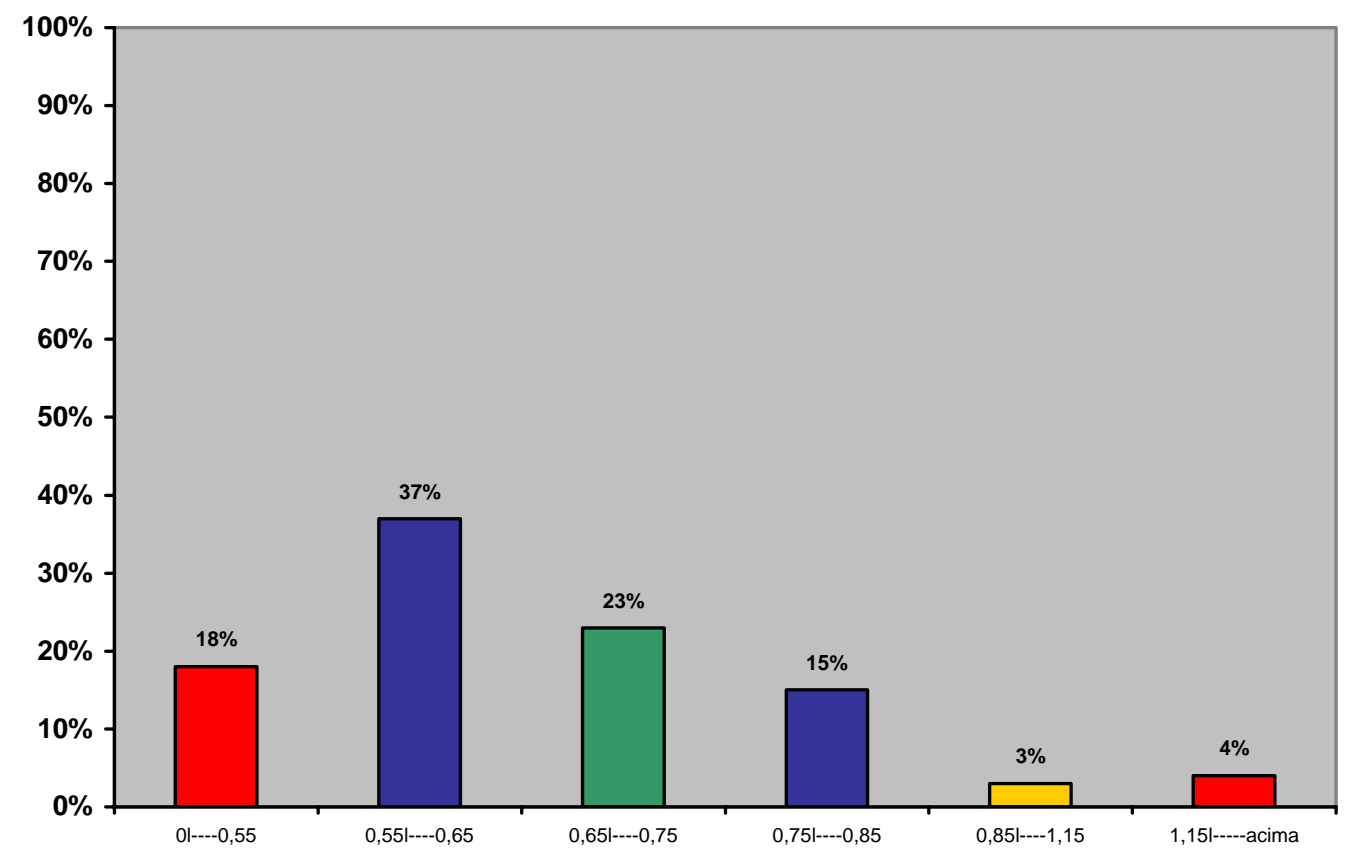

FIGURA 23 - Classificação das amostras de água da ETA e dos poços de acordo com a concentração de flúor, nos meses de maio, agosto e novembro de 2003 e fevereiro de 2004, em Bauru 
No período de maio de 2003 a fevereiro de 2004 foram coletadas e analisadas 697 amostras de água, embora o número estipulado inicialmente fosse de 756. No setor de abastecimento dos poços Santa Cecília/Garrafa/Beija Flor, o ponto de coleta de número 30, e, no setor do poço Bauru 25, o de número 54, foram perdidos porque os voluntários se mudaram do endereço. As demais perdas se devem ao fato de que os voluntários não coletaram as amostras, por esquecimento ou falta de água no dia determinado para coleta. Do total das amostras coletas, a média da concentração de flúor variou entre 0,10 (Setor Lotes Urbanizados) a 0,91 mg/L (Setor Padilha/Consolação) (TABELAS 36, 36.1, 38, 38.1, 40, 40.1 e 42, 42.1). A reprodutibilidade obtida com a análise destas amostras foi de $98,89 \%$.

No mês de maio foram coletadas 180 amostras nas residências e de acordo com a concentração de flúor, cerca de 58\% foram classificadas entre os limites mínimo e máximo de flúor aceitáceis, e, 31\%, como inaceitáveis (TABELA 37). No mês de agosto foram coletadas 168 amostras e destas, $46 \%$ foram consideradas como inaceitáveis e 54\% entre os limites mínimo e máximo aceitáveis (TABELA 39). Entretanto, no mês de novembro, das 176 amostras coletadas, cerca de 85\% foram classificadas entre os limites mínimos e máximos aceitáveis, 4\% como inadequadas, e apenas, 11 \% como inaceitáveis (TABELA 41). Em fevereiro de 2004 foram coletadas 173 amostras, e destas, cerca de $47 \%$ foram classificadas como dentro dos limites mínimo e máximo de flúor tido como aceitáveis e 51\%, como inaceitáveis. Estes resultados mostraram-se próximos daqueles verificados no mês agosto e opostos aos de novembro (TABELA 43). Através das 
TABELAS 44, 44.1 e 45 pode-se analisar a variação na média das concentrações de flúor das 697 amostras coletadas nas residências dos diferentes setores de abastecimento de Bauru, durante todo o período de maio de 2003 a fevereiro de 2004, assim como, a classificação destas amostras de acordo com a concentração de flúor. A média das concentrações de flúor variou entre $0,26 \mathrm{mg} / \mathrm{L}$ (Setor dos poços Parque Real I e II) $0,78 \mathrm{mg} / \mathrm{L}$ (Setor do poço Octávio Rasi) (TABELAS 44 e 44.1). A classificação das amostras, segundo a concentração de flúor, indica que cerca de $34 \%$ das amostras, coletadas no período de maio de 2003 a fevereiro de 2004, em Bauru, foram consideradas inaceitáveis, 4\% inadequadas e 62\% variando entre os limites de mínima e máxima concentração aceitável (TABELA 45). 
TABELA 36 - Concentração de flúor na água de abastecimento público nos diferentes setores, no mês de maio, em Bauru, 2003

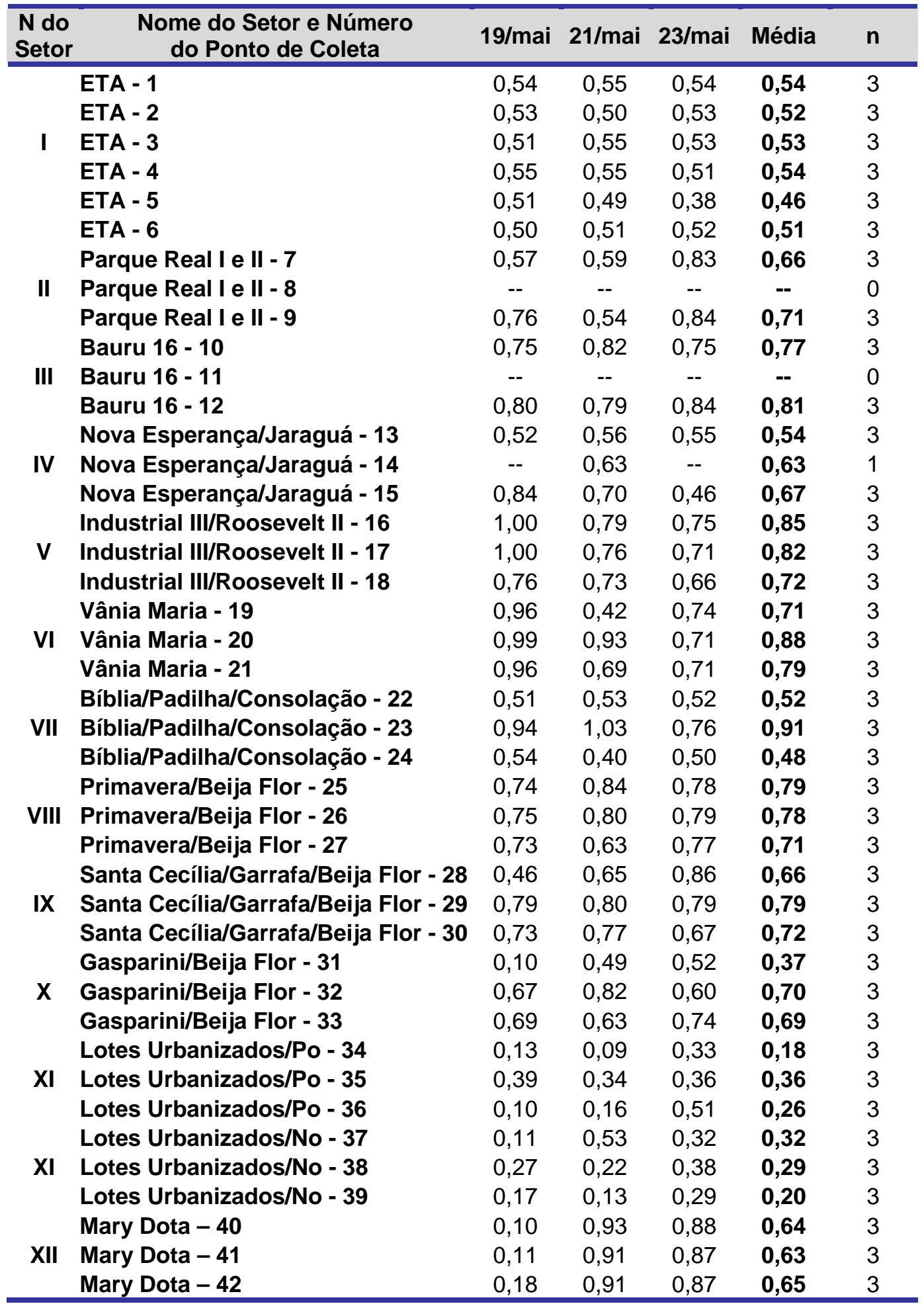


TABELA 36.1 - Concentração de flúor na água de abastecimento público nos diferentes setores, no mês de maio, em Bauru, 2003

\begin{tabular}{|c|c|c|c|c|c|c|}
\hline $\begin{array}{l}\mathrm{N} \text { do } \\
\text { Setor }\end{array}$ & $\begin{array}{l}\text { Nome do Setor e Número } \\
\text { do Ponto de Coleta }\end{array}$ & 19/mai & 21/mai & 23/mai & Média & $\mathbf{n}$ \\
\hline & Cruzeiro do Sul - 43 & 0,66 & 0,65 & 0,63 & 0,65 & 3 \\
\hline \multirow[t]{3}{*}{ XIII } & Cruzeiro do Sul - 44 & 0,68 & 0,60 & 0,58 & 0,62 & 3 \\
\hline & Cruzeiro do Sul - 45 & 0,63 & 0,66 & 0,51 & 0,60 & 3 \\
\hline & Octávio Rasi - 46 & 0,80 & 0,82 & 0,98 & 0,87 & 3 \\
\hline \multirow{3}{*}{ XIV } & Octávio Rasi - 47 & 0,85 & 0,84 & 0,91 & 0,87 & 3 \\
\hline & Octávio Rasi - 48 & 0,80 & 0,92 & 0,84 & 0,85 & 3 \\
\hline & Funcraf/Santa Terezinha - 49 & 0,65 & 0,67 & 0,63 & 0,65 & 3 \\
\hline \multirow{3}{*}{$x V$} & Funcraf/Santa Terezinha - 50 & 0,67 & 0,64 & 0,70 & 0,67 & 3 \\
\hline & Funcraf/Santa Terezinha - 51 & 0,66 & 0,67 & 0,65 & 0,66 & 3 \\
\hline & Bauru $25-52$ & 0,66 & 0,53 & -- & 0,60 & 2 \\
\hline \multirow{3}{*}{ XVI } & Bauru $25-53$ & 0,51 & 0,61 & 0,66 & 0,59 & 3 \\
\hline & Bauru $25-54$ & 0,60 & 0,65 & 0,59 & 0,61 & 3 \\
\hline & Geisel II - 55 & 0,62 & 0,66 & 0,61 & 0,63 & 3 \\
\hline \multirow{3}{*}{ XVII } & Geisel II - 56 & 0,59 & 0,65 & 0,64 & 0,63 & 3 \\
\hline & Geisel II - 57 & 0,55 & 0,64 & 0,62 & 0,60 & 3 \\
\hline & Nações - 58 & 0,66 & 0,74 & 0,70 & 0,70 & 3 \\
\hline \multirow[t]{3}{*}{ XVIII } & Nações - 59 & 0,63 & 0,71 & 0,68 & 0,67 & 3 \\
\hline & Nações - 60 & 0,51 & 0,57 & 0,56 & 0,55 & 3 \\
\hline & Samambaia - 61 & 0,62 & 0,61 & 0,60 & 0,61 & 3 \\
\hline \multirow{3}{*}{$\mathrm{XIX}$} & Samambaia - 62 & 0,57 & 0,50 & 0,49 & 0,52 & 3 \\
\hline & Samambaia - 63 & 0,63 & 0,65 & 0,54 & 0,61 & 3 \\
\hline & & & & & Total & 180 \\
\hline
\end{tabular}

TABELA 37 - Classificação das amostras de água de acordo com o teor de flúor, dos diferentes setores de abastecimento de Bauru, no mês de maio de 2003

\begin{tabular}{|c|c|c|c|}
\hline Teor de flúor & $\mathbf{n}$ & $\%$ & Classificação \\
\hline O—- $0,55 \mathrm{mg} / \mathrm{L}$ & 56 & 31 & Inaceitável \\
\hline $0,55 \vdash 0,65 \mathrm{mg} / \mathrm{L}$ & 36 & 20 & Sub-ótima \\
\hline $0,65 \vdash 0,75 \mathrm{mg} / \mathrm{L}$ & 38 & 21 & Ótima \\
\hline $0,75 \vdash 0,85 \mathrm{mg} / \mathrm{L}$ & 31 & 17 & Supra-ótima \\
\hline $0,85 \vdash 1,15 \mathrm{mg} / \mathrm{L}$ & 19 & 11 & Inadequada \\
\hline 1,15— acima & 0 & 0 & Inaceitável \\
\hline Total & 180 & 100 & \\
\hline
\end{tabular}




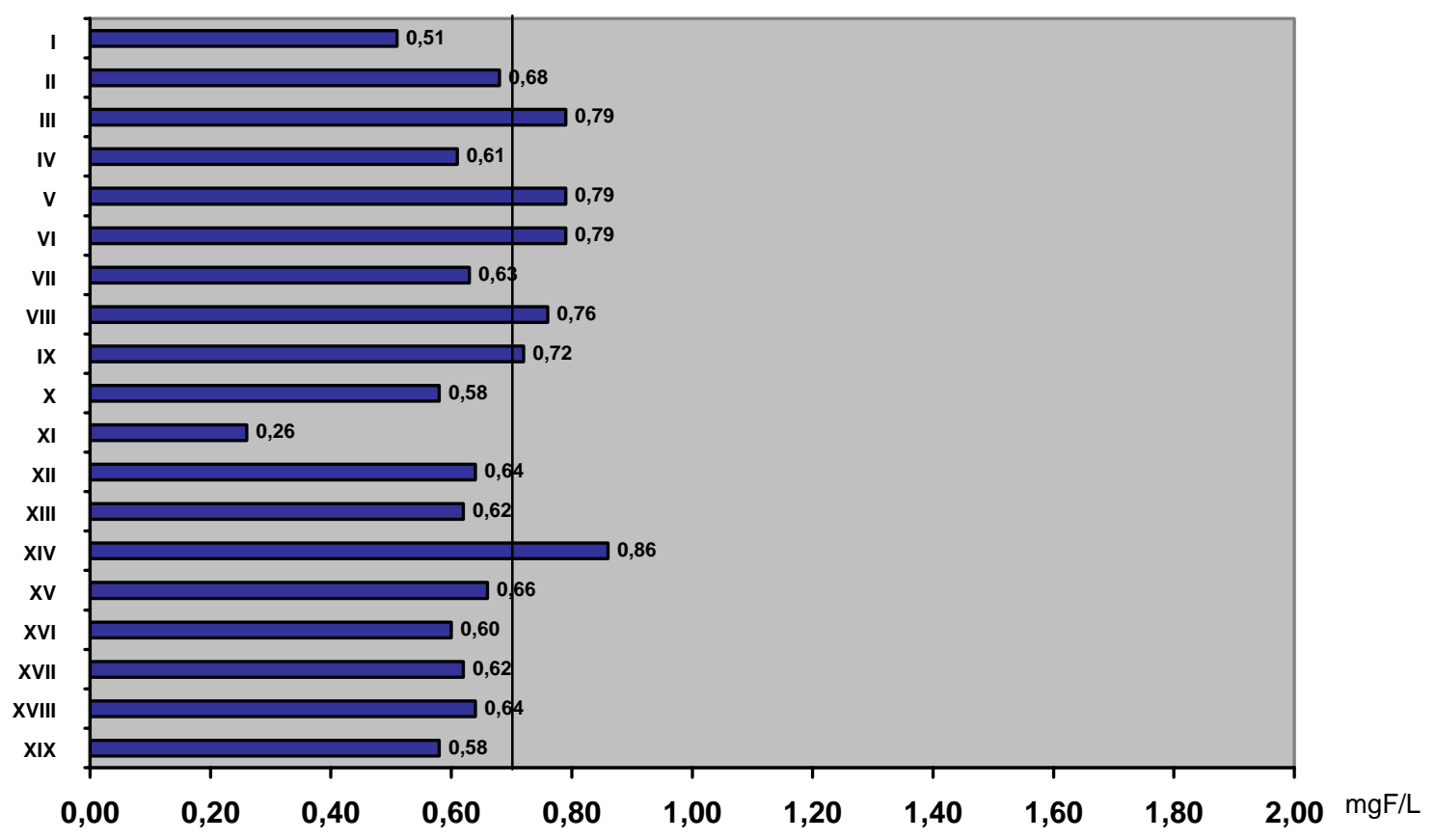

FIGURA 24 - Concentração média de flúor, nos diferentes setores de abastecimento de Bauru, no mês de maio de 2003

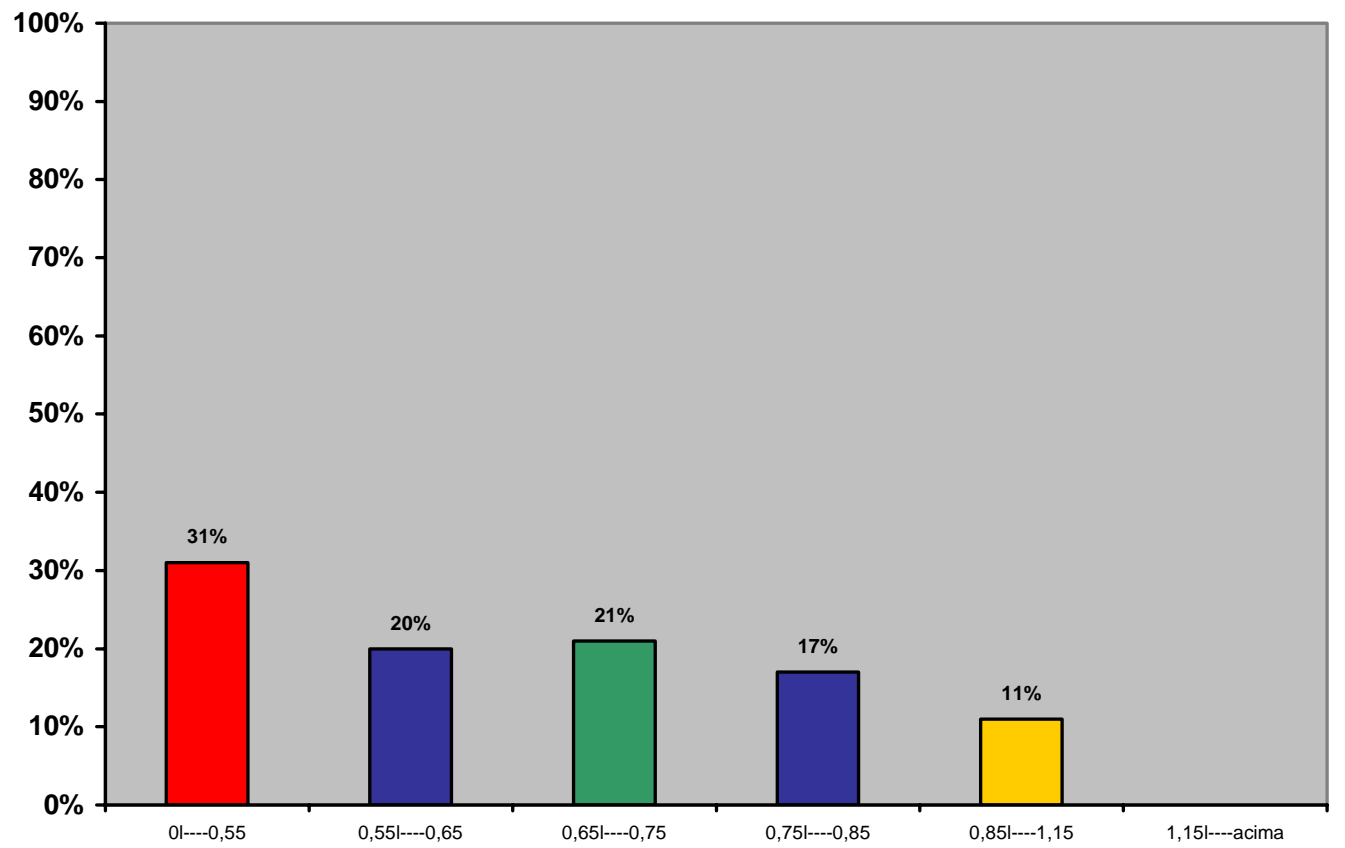

FIGURA 25 - Classificação das amostras de água de acordo com a concentração de flúor nos diferentes setores de abastecimento de Bauru, no mês de maio de 2003 
TABELA 38 - Concentração de flúor na água das residências nos diferentes setores de abastecimento público, no mês de agosto, em Bauru, 2003

\begin{tabular}{|c|c|c|c|c|c|c|}
\hline $\begin{array}{l}\mathrm{N} \text { do } \\
\text { Setor }\end{array}$ & $\begin{array}{l}\text { Nome do Setor e Número } \\
\text { do Ponto de coleta }\end{array}$ & 18/ago & 20/ago & 22/ago & Média & $\mathbf{n}$ \\
\hline \multirow{6}{*}{$\mathbf{I}$} & ETA - 1 & 0,55 & 0,54 & 0,44 & 0,51 & 3 \\
\hline & ETA - 2 & 0,40 & 0,52 & 0,37 & 0,43 & 3 \\
\hline & ETA - 3 & 0,52 & 0,56 & 0,45 & 0,51 & 3 \\
\hline & ETA - 4 & 0,55 & 0,66 & 0,53 & 0,58 & 3 \\
\hline & ETA - 5 & 0,54 & 0,52 & 0,38 & 0,48 & 3 \\
\hline & ETA - 6 & 0,50 & 0,52 & 0,41 & 0,48 & 3 \\
\hline \multirow{4}{*}{ II } & Parque Real I e II - 7 & 1,28 & 0,71 & 0,60 & 0,86 & 3 \\
\hline & Parque Real I e II - 8 & 0,52 & 0,63 & 0,51 & 0,55 & 3 \\
\hline & Parque Real I e II - 9 & 0,48 & 0,49 & 0,60 & 0,52 & 3 \\
\hline & Bauru 16 - 10 & 0,72 & 0,73 & 0,72 & 0,72 & 3 \\
\hline \multirow[t]{2}{*}{ III } & Bauru 16 - 11 & -- & 0,66 & 0,59 & 0,63 & 2 \\
\hline & Bauru 16 - 12 & 0,72 & 0,73 & 0,72 & 0,72 & 3 \\
\hline \multirow{3}{*}{ IV } & Nova Esperança/Jaraguá - 13 & -- & -- & -- & -- & 0 \\
\hline & Nova Esperança/Jaraguá - 14 & 0,60 & -- & 0,57 & 0,63 & 2 \\
\hline & Nova Esperança/Jaraguá - 15 & 0,46 & 0,51 & 0,57 & 0,51 & 3 \\
\hline \multirow{3}{*}{ v } & Industrial III/Roosevelt II - 16 & 0,63 & 0,60 & 0,58 & 0,60 & 3 \\
\hline & Industrial III/Roosevelt II - 17 & 0,63 & 0,61 & 0,57 & 0,60 & 3 \\
\hline & Industrial III/Roosevelt II - 18 & 0,65 & 0,52 & 0,59 & 0,59 & 3 \\
\hline \multirow{3}{*}{ VI } & Vânia Maria - 19 & 0,65 & 0,62 & 0,45 & 0,57 & 3 \\
\hline & Vânia Maria - 20 & 0,67 & 0,56 & 0,45 & 0,56 & 3 \\
\hline & Vânia Maria - 21 & 0,61 & 0,61 & 0,55 & 0,59 & 3 \\
\hline \multirow{3}{*}{ VII } & Bíblia/Padilha/Consolação - 22 & 0,63 & 0,55 & 0,44 & 0,54 & 3 \\
\hline & Bíblia/Padilha/Consolação - 23 & 0,60 & 0,63 & 0,48 & 0,57 & 3 \\
\hline & Bíblia/Padilha/Consolação - 24 & 0,55 & 0,53 & 0,48 & 0,52 & 3 \\
\hline \multirow{3}{*}{ VIII } & Primavera/Beija Flor - 25 & 0,51 & 0,55 & 0,49 & 0,52 & 3 \\
\hline & Primavera/Beija Flor - 26 & 0,45 & 0,33 & 0,18 & 0,32 & 3 \\
\hline & Primavera/Beija Flor - 27 & 0,49 & 0,57 & 0,51 & 0,52 & 3 \\
\hline \multirow{3}{*}{ IX } & Santa Cecília/Garrafa/Beija Flor - 28 & 0,52 & 0,58 & 0,42 & 0,51 & 3 \\
\hline & Santa Cecília/Garrafa/Beija Flor - 29 & 0,44 & 0,43 & 0,26 & 0,38 & 3 \\
\hline & Santa Cecília/Garrafa/Beija Flor - 30 & 0,39 & 0,38 & 0,15 & 0,31 & 3 \\
\hline \multirow{3}{*}{$\mathbf{x}$} & Gasparini/Beija Flor - 31 & 0,55 & 0,59 & 0,53 & 0,56 & 3 \\
\hline & Gasparini/Beija Flor - 32 & -- & -- & -- & -- & 0 \\
\hline & Gasparini/Beija Flor - 33 & 0,57 & 0,53 & 0,44 & 0,51 & 3 \\
\hline \multirow{3}{*}{$\mathbf{X I}$} & Lotes Urbanizados/Po - 34 & 0,64 & 0,77 & 0,68 & 0,70 & 3 \\
\hline & Lotes Urbanizados/Po - 35 & -- & -- & -- & -- & 0 \\
\hline & Lotes Urbanizados/Po - 36 & 0,62 & 0,71 & 0,49 & 0,61 & 3 \\
\hline \multirow{3}{*}{$\mathbf{X I}$} & Lotes Urbanizados/No - 37 & 0,68 & 0,71 & 0,49 & 0,63 & 3 \\
\hline & Lotes Urbanizados/No - 38 & 0,66 & 0,61 & 0,52 & 0,60 & 3 \\
\hline & Lotes Urbanizados/No - 39 & 0,63 & 0,69 & 0,53 & 0,62 & 3 \\
\hline \multirow{3}{*}{ XII } & Mary Dota - 40 & 0,67 & 0,63 & 0,50 & 0,60 & 3 \\
\hline & Mary Dota - 41 & 0,62 & 0,64 & 0,52 & 0,59 & 3 \\
\hline & Mary Dota - 42 & 0,65 & 0,62 & 0,46 & 0,58 & 3 \\
\hline
\end{tabular}


TABELA 38.1 - Concentração de flúor na água das residências nos diferentes setores de abastecimento público, no mês de agosto, em Bauru, 2003

\begin{tabular}{|c|c|c|c|c|c|c|}
\hline $\begin{array}{l}N \text { do } \\
\text { Setor }\end{array}$ & $\begin{array}{l}\text { Nome do Setor e Número } \\
\text { do Ponto de coleta }\end{array}$ & 18/ago & 20/ago & 22/ago & Média & $\mathbf{n}$ \\
\hline \multirow{3}{*}{ XIII } & Cruzeiro do Sul - 43 & 0,60 & 0,62 & 0,50 & 0,57 & 3 \\
\hline & Cruzeiro do Sul - 44 & 0,62 & 0,62 & 0,50 & 0,58 & 3 \\
\hline & Cruzeiro do Sul - 45 & 0,58 & 0,61 & 0,47 & 0,55 & 3 \\
\hline \multirow{3}{*}{ XIV } & Octávio Rasi - 46 & 0,78 & 0,53 & 0,51 & 0,61 & 3 \\
\hline & Octávio Rasi - 47 & 0,41 & 0,41 & -- & 0,41 & 2 \\
\hline & Octávio Rasi - 48 & -- & 0,51 & -- & 0,51 & 1 \\
\hline \multirow{3}{*}{$x V$} & Funcraf/Santa Terezinha - 49 & 0,57 & 0,55 & 0,43 & 0,52 & 3 \\
\hline & Funcraf/Santa Terezinha - 50 & 0,58 & 0,60 & 0,45 & 0,54 & 3 \\
\hline & Funcraf/Santa Terezinha - 51 & 0,58 & 0,60 & 0,45 & 0,54 & 3 \\
\hline \multirow{3}{*}{$\mathrm{XVI}$} & Bauru $25-52$ & -- & -- & -- & - & 0 \\
\hline & Bauru $25-53$ & 0,59 & 0,64 & 0,50 & 0,58 & 3 \\
\hline & Bauru $25-54$ & -- & -- & -- & - & 0 \\
\hline \multirow{3}{*}{ XVII } & Geisel II - 55 & 0,60 & 0,62 & 0,36 & 0,53 & 3 \\
\hline & Geisel II - 56 & 0,61 & 0,61 & 0,50 & 0,57 & 3 \\
\hline & Geisel II - 57 & 0,64 & 0,64 & 0,53 & 0,60 & 3 \\
\hline \multirow{3}{*}{ XVIII } & Nações - 58 & 0,64 & 0,62 & 0,45 & 0,57 & 3 \\
\hline & Nações - 59 & 0,63 & -- & 0,47 & 0,55 & 2 \\
\hline & Nações - 60 & 0,54 & 0,53 & 0,43 & 0,50 & 3 \\
\hline \multirow{4}{*}{$\mathrm{XIX}$} & Samambaia - 61 & 0,55 & 0,46 & 0,56 & 0,52 & 3 \\
\hline & Samambaia - 62 & 0,51 & 0,55 & 0,38 & 0,48 & 3 \\
\hline & Samambaia - 63 & 0,61 & 0,36 & 0,50 & 0,49 & 3 \\
\hline & & & & & Total & 168 \\
\hline
\end{tabular}

TABELA 39 - Classificação das amostras de água de acordo com o teor de flúor, dos diferentes setores de abastecimento de Bauru, no mês de agosto de 2003

\begin{tabular}{cccc}
\hline Teor de flúor & $\mathbf{n}$ & $\%$ & Classificação \\
\hline $01-0,55 \mathrm{mg} / \mathrm{L}$ & 77 & 46 & Inaceitável \\
$0,55 \models-0,65 \mathrm{mg} / \mathrm{L}$ & 68 & 40 & Sub-ótima \\
$0,65-0,75 \mathrm{mg} / \mathrm{L}$ & 21 & 13 & Ótima \\
$0,75-0,85 \mathrm{mg} / \mathrm{L}$ & 1 & 0,5 & Supra-ótima \\
$0,85 \models-15 \mathrm{mg} / \mathrm{L}$ & 0 & 0 & Inadequada \\
$1,15 \models$ acima & 1 & 0,5 & Inaceitável \\
\hline Total & $\mathbf{1 6 8}$ & $\mathbf{1 0 0}$ & \\
\hline
\end{tabular}




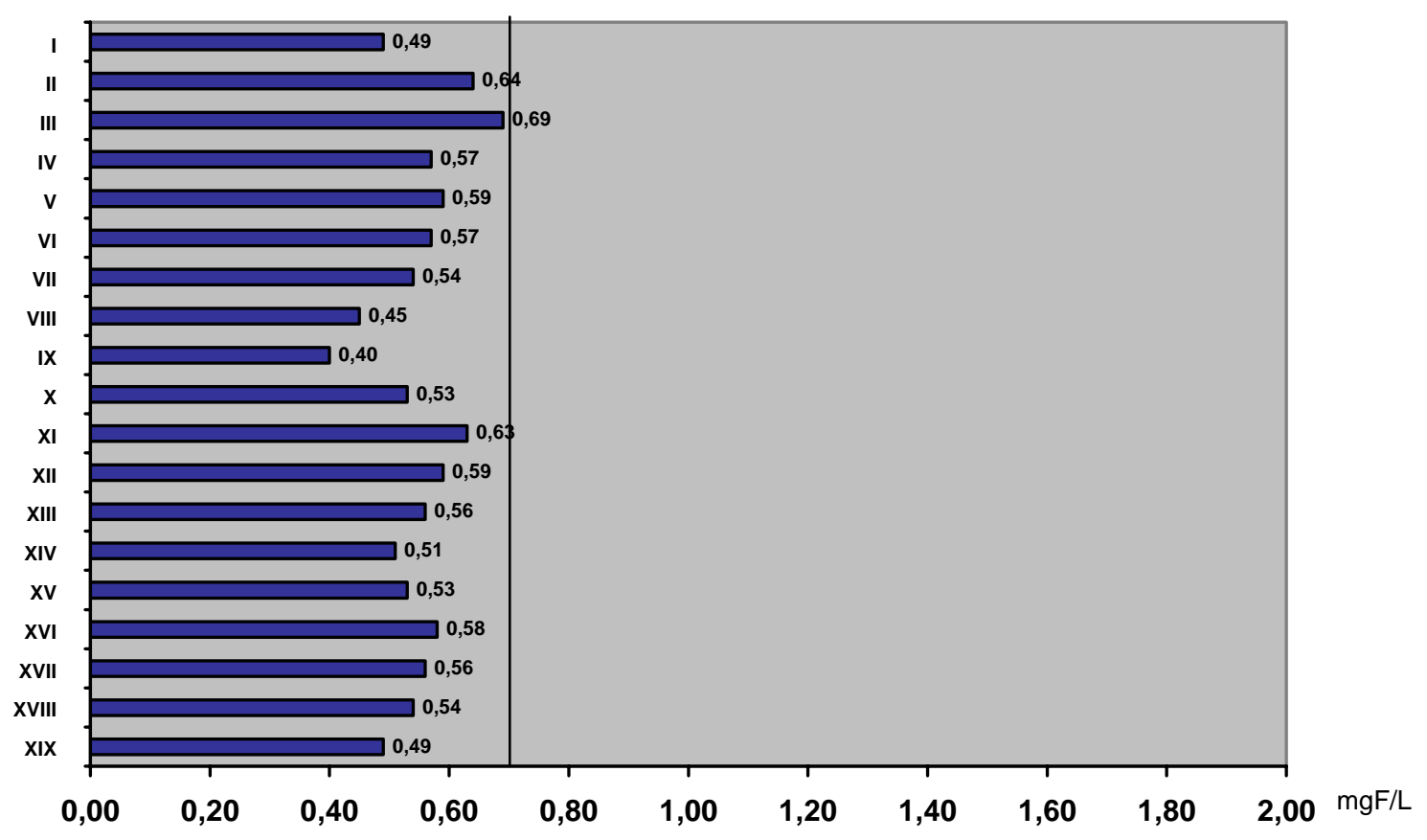

FIGURA 26 - Concentração média de flúor, nos diferentes setores de abastecimento de Bauru, no mês de agosto de 2003

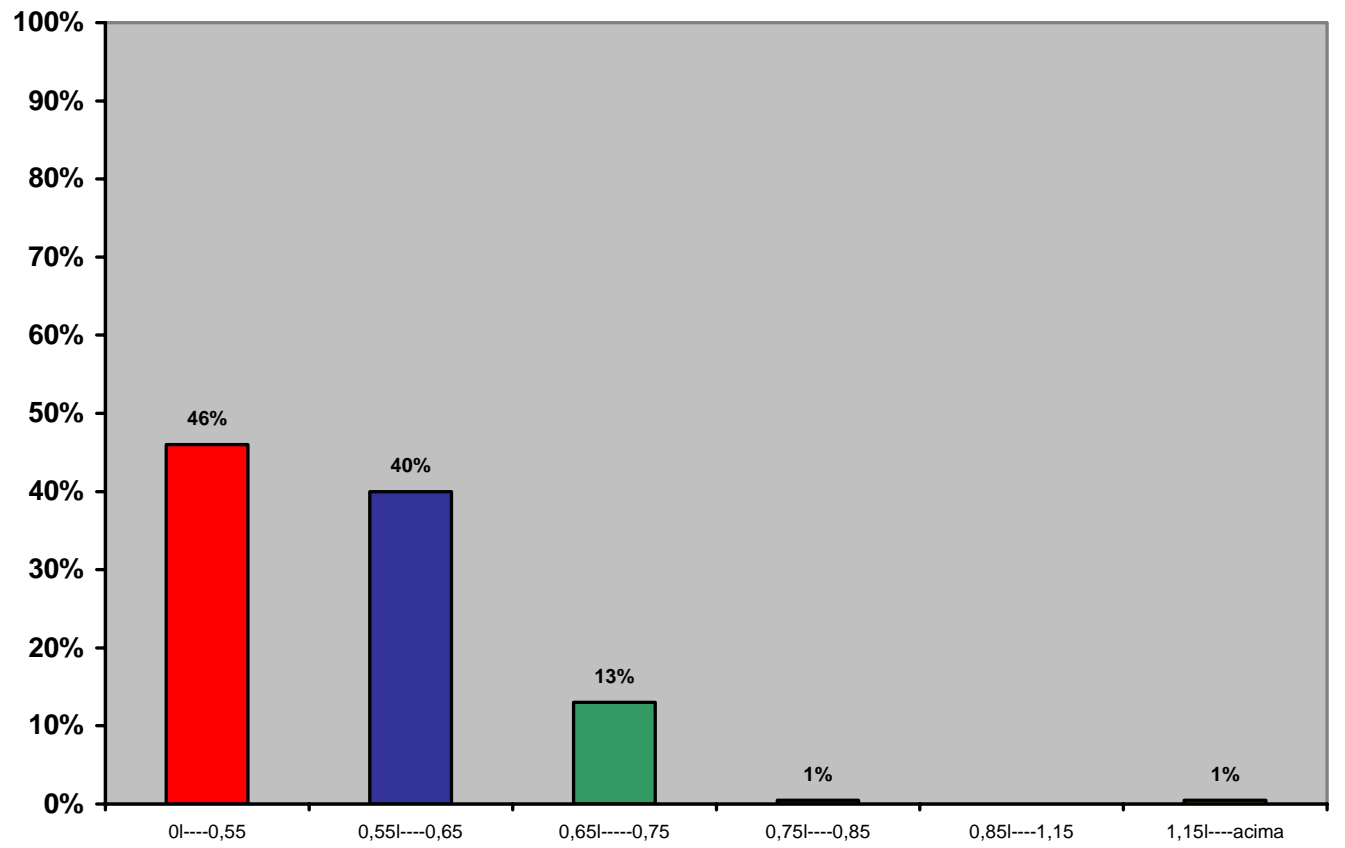

FIGURA 27 - Classificação das amostras de água de acordo com a concentração de flúor nos diferentes setores de abastecimento de Bauru, no mês de agosto de 2003 
TABELA 40 - Concentração de flúor na água das residências nos diferentes setores de abastecimento público, no mês de novembro, em Bauru, 2003

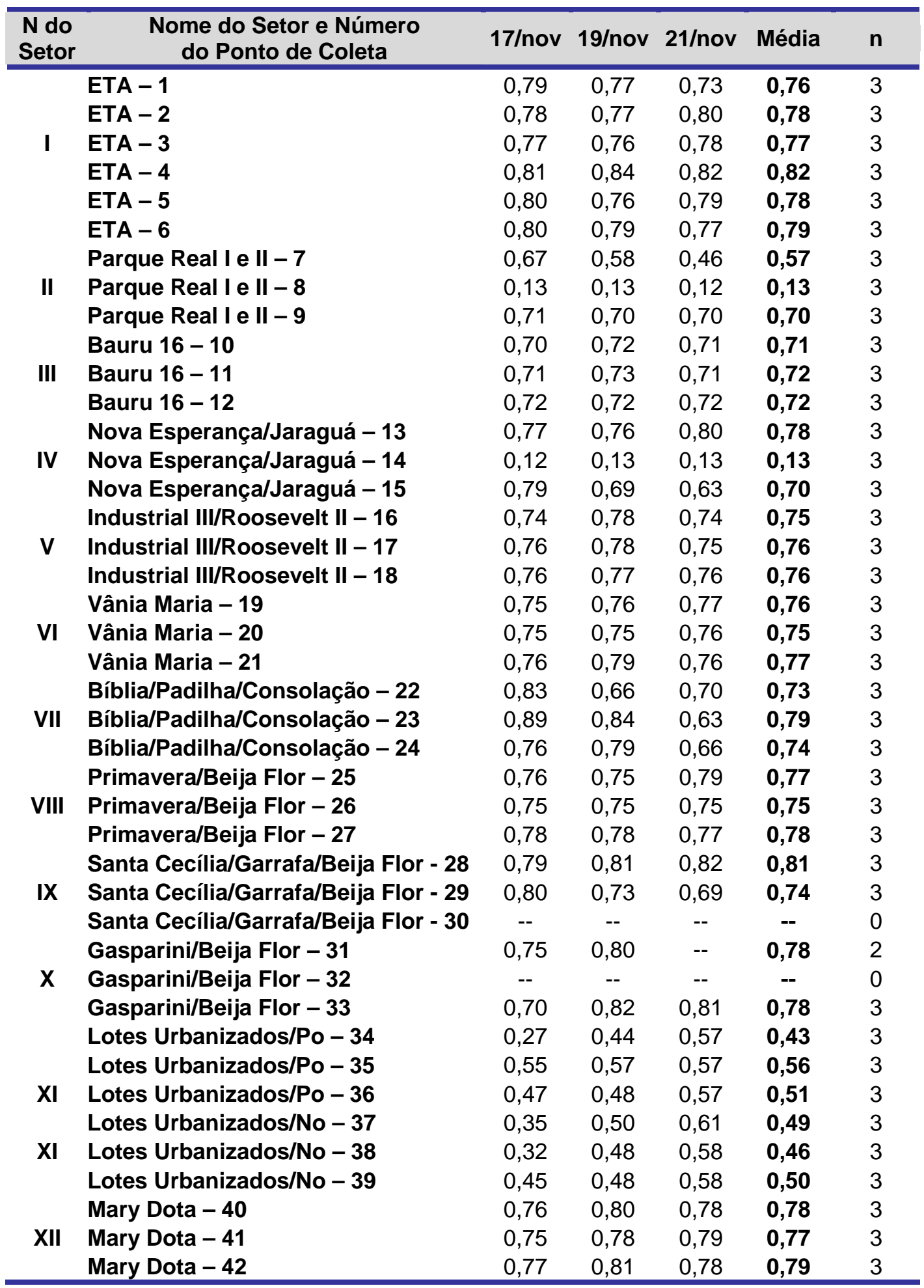


TABELA 40.1 - Concentração de flúor na água das residências nos diferentes setores de abastecimento público, no mês de novembro, em Bauru, 2003

\begin{tabular}{|c|c|c|c|c|c|c|}
\hline $\begin{array}{l}\mathrm{N} \text { do } \\
\text { Setor }\end{array}$ & $\begin{array}{l}\text { Nome do Setor e Número } \\
\text { do Ponto de Coleta }\end{array}$ & 17 Inov & $19 /$ nov & $21 /$ nov & Média & $\mathbf{n}$ \\
\hline & Cruzeiro do Sul - 43 & 0,43 & 0,67 & 0,74 & 0,61 & 3 \\
\hline \multirow{3}{*}{ XIII } & Cruzeiro do Sul - 44 & 0,72 & 0,80 & 0,79 & 0,77 & 3 \\
\hline & Cruzeiro do Sul - 45 & 0,40 & 0,73 & 0,76 & 0,63 & 3 \\
\hline & Octávio Rasi - 46 & 0,81 & 0,94 & 0,87 & 0,87 & 3 \\
\hline \multirow[t]{3}{*}{ XIV } & Octávio Rasi - 47 & 0,79 & 0,82 & 0,81 & 0,81 & 3 \\
\hline & Octávio Rasi - 48 & 0,73 & 0,86 & 0,93 & 0,84 & 3 \\
\hline & Funcraf/Santa Terezinha - 49 & 0,64 & 0,66 & 0,64 & 0,65 & 3 \\
\hline \multirow[t]{3}{*}{$X V$} & Funcraf/Santa Terezinha - 50 & 0,64 & 0,67 & 0,66 & 0,66 & 3 \\
\hline & Funcraf/Santa Terezinha - 51 & 0,64 & 0,66 & 0,68 & 0,66 & 3 \\
\hline & Bauru $25-52$ & 0,83 & 0,76 & 0,83 & 0,81 & 3 \\
\hline \multirow[t]{3}{*}{ XVI } & Bauru $25-53$ & 0,85 & 0,85 & 0,82 & 0,84 & 3 \\
\hline & Bauru $25-54$ & -- & -- & -- & -- & 0 \\
\hline & Geisel II - 55 & 0,72 & 0,72 & 0,74 & 0,73 & 3 \\
\hline \multirow[t]{3}{*}{ XVII } & Geisel II - 56 & 0,55 & 0,72 & 0,74 & 0,67 & 3 \\
\hline & Geisel II - 57 & 0,74 & 0,73 & 0,74 & 0,74 & 3 \\
\hline & Nações - 58 & 0,74 & 0,77 & 0,75 & 0,75 & 3 \\
\hline \multirow[t]{3}{*}{ XVIII } & Nações - 59 & 0,77 & 0,76 & 0,76 & 0,76 & 3 \\
\hline & Nações - 60 & 0,79 & 0,77 & 0,78 & 0,78 & 3 \\
\hline & Samambaia - 61 & 0,78 & 0,77 & 0,78 & 0,78 & 3 \\
\hline \multirow[t]{3}{*}{ XIX } & Samambaia - 62 & -- & -- & -- & -- & 0 \\
\hline & Samambaia - 63 & 0,76 & 0,75 & 0,75 & 0,75 & 3 \\
\hline & & & & & Total & 176 \\
\hline
\end{tabular}

TABELA 41 - Classificação das amostras de água de acordo com o teor de flúor, dos diferentes setores de abastecimento de Bauru, no mês de novembro de 2003

\begin{tabular}{rccc}
\hline Teor de flúor & $\mathbf{n}$ & $\%$ & Classificação \\
\hline $01-0,55 \mathrm{mg} / \mathrm{L}$ & 19 & 11 & Inaceitável \\
$0,55 \models-0,65 \mathrm{mg} / \mathrm{L}$ & 15 & 9 & Sub-ótima \\
$0,65-0,75 \mathrm{mg} / \mathrm{L}$ & 43 & 24 & Ótima \\
$0,75 \models 0,85 \mathrm{mg} / \mathrm{L}$ & 92 & 52 & Supra-ótima \\
$0,85 \models-15 \mathrm{mg} / \mathrm{L}$ & 7 & 4 & Inadequada \\
$1,15 \models$ acima & 0 & 0 & Inaceitável \\
\hline Total & $\mathbf{1 7 6}$ & $\mathbf{1 0 0}$ & \\
\hline
\end{tabular}




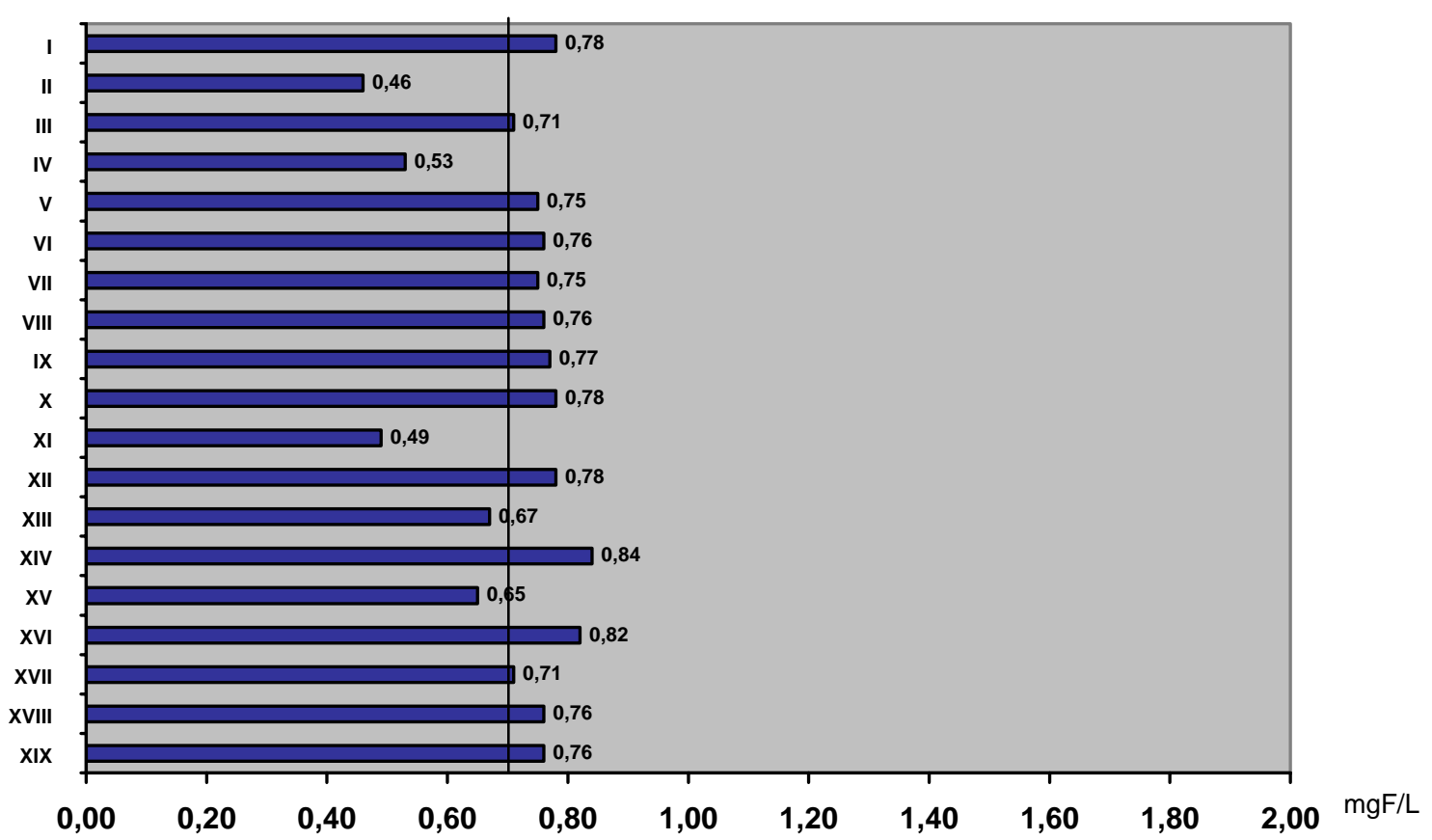

FIGURA 28 - Concentração média de flúor, nos diferentes setores de abastecimento de Bauru, no mês de novembro de 2003

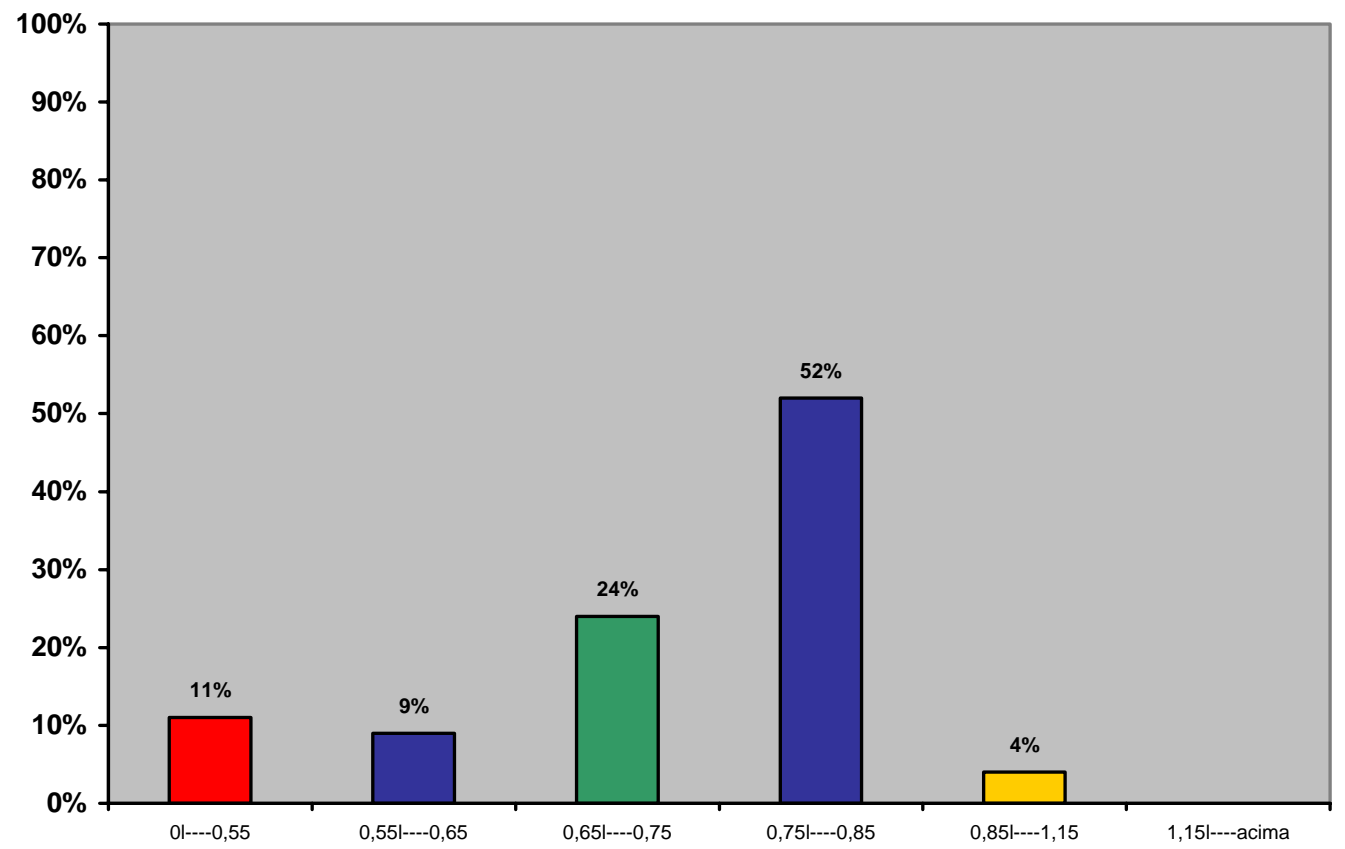

FIGURA 29 - Classificação das amostras de água de acordo com a concentração de flúor nos diferentes setores de abastecimento de Bauru, no mês de novembro de 2003 
TABELA 42 - Concentração de flúor na água das residências nos diferentes setores de abastecimento público, no mês de fevereiro, em Bauru, 2004

\begin{tabular}{|c|c|c|c|c|c|c|}
\hline $\begin{array}{l}\mathrm{N} \text { do } \\
\text { Setor }\end{array}$ & $\begin{array}{l}\text { Nome do Setor e Número } \\
\text { do Ponto de Coleta }\end{array}$ & 16/fev & $18 / f e v$ & $20 / f e v$ & Média & $\mathbf{n}$ \\
\hline \multirow{6}{*}{$\mathbf{I}$} & ETA - 1 & 0,48 & 0,46 & 0,52 & 0,49 & 3 \\
\hline & ETA - 2 & 0,46 & 0,47 & 0,51 & 0,48 & 3 \\
\hline & ETA - 3 & 0,49 & 0,47 & 0,51 & 0,49 & 3 \\
\hline & ETA - 4 & 0,53 & 0,47 & 0,53 & 0,51 & 3 \\
\hline & ETA - 5 & 0,44 & 0,45 & 0,50 & 0,46 & 3 \\
\hline & ETA - 6 & 0,49 & 0,43 & 0,51 & 0,48 & 3 \\
\hline \multirow{4}{*}{ II } & Parque Real I e II - 7 & 0,85 & 0,70 & 0,97 & 0,84 & 3 \\
\hline & Parque Real I e II - 8 & 0,10 & 0,10 & 0,10 & 0,10 & 3 \\
\hline & Parque Real I e II - 9 & 0,75 & 0,72 & 0,60 & 0,69 & 3 \\
\hline & Bauru 16 - 10 & -- & -- & -- & -- & 0 \\
\hline \multirow[t]{3}{*}{ III } & Bauru 16 - 11 & 0,65 & 0,67 & 0,86 & 0,73 & 3 \\
\hline & Bauru 16 - 12 & -- & -- & -- & -- & 0 \\
\hline & Nova Esperança/Jaraguá - 13 & 0,62 & 0,59 & -- & 0,61 & 2 \\
\hline \multirow[t]{3}{*}{ IV } & Nova Esperança/Jaraguá - 14 & 0,60 & 0,50 & 0,63 & 0,58 & 3 \\
\hline & Nova Esperança/Jaraguá - 15 & 0,59 & 0,53 & 0,63 & 0,58 & 3 \\
\hline & Industrial III/Roosevelt II - 16 & 0,58 & 0,46 & 0,63 & 0,56 & 3 \\
\hline \multirow[t]{3}{*}{ V } & Industrial III/Roosevelt II - 17 & 0,57 & 0,49 & 0,62 & 0,56 & 3 \\
\hline & Industrial III/Roosevelt II - 18 & 0,57 & 0,48 & 0,61 & 0,55 & 3 \\
\hline & Vânia Maria - 19 & 0,56 & 0,46 & 0,60 & 0,54 & 3 \\
\hline \multirow[t]{3}{*}{ VI } & Vânia Maria - 20 & 0,54 & 0,44 & 0,61 & 0,53 & 3 \\
\hline & Vânia Maria - 21 & 0,54 & 0,46 & 0,58 & 0,53 & 3 \\
\hline & Bíblia/Padilha/Consolação - 22 & 0,53 & 0,48 & 0,75 & 0,59 & 3 \\
\hline \multirow[t]{3}{*}{ VII } & Bíblia/Padilha/Consolação - 23 & 0,61 & 0,50 & 0,74 & 0,62 & 3 \\
\hline & Bíblia/Padilha/Consolação - 24 & 0,61 & 0,50 & 0,73 & 0,61 & 3 \\
\hline & Primavera/Beija Flor - 25 & 0,55 & 0,69 & 0,57 & 0,60 & 3 \\
\hline \multirow[t]{3}{*}{ VIII } & Primavera/Beija Flor - 26 & 0,51 & 0,65 & 0,58 & 0,58 & 3 \\
\hline & Primavera/Beija Flor - 27 & 0,54 & 0,78 & 0,59 & 0,64 & 3 \\
\hline & Santa Cecília/Garrafa/Beija Flor - 28 & 0,38 & 0,59 & 0,76 & 0,58 & 3 \\
\hline \multirow[t]{3}{*}{ IX } & Santa Cecília/Garrafa/Beija Flor - 29 & 0,51 & 0,56 & 0,54 & 0,54 & 3 \\
\hline & Santa Cecília/Garrafa/Beija Flor - 30 & -- & -- & -- & -- & 0 \\
\hline & Gasparini/Beija Flor - 31 & 0,62 & 0,51 & 0,54 & 0,56 & 3 \\
\hline \multirow[t]{3}{*}{$x$} & Gasparini/Beija Flor - 32 & 0,64 & 0,57 & 0,52 & 0,58 & 3 \\
\hline & Gasparini/Beija Flor - 33 & 0,45 & 0,57 & 0,80 & 0,61 & 3 \\
\hline & Lotes Urbanizados/Po - 34 & 0,49 & 0,53 & 0,75 & 0,59 & 3 \\
\hline \multirow[t]{3}{*}{$\mathbf{X I}$} & Lotes Urbanizados/Po - 35 & 0,55 & 0,53 & 0,55 & 0,54 & 3 \\
\hline & Lotes Urbanizados/Po - 36 & 0,31 & 0,48 & 0,67 & 0,49 & 3 \\
\hline & Lotes Urbanizados/No - 37 & 0,46 & 0,44 & 0,58 & 0,49 & 3 \\
\hline \multirow[t]{3}{*}{$\mathbf{X I}$} & Lotes Urbanizados/No - 38 & 0,44 & 0,51 & 0,69 & 0,55 & 3 \\
\hline & Lotes Urbanizados/No - 39 & 0,50 & 0,53 & 0,69 & 0,57 & 3 \\
\hline & Mary Dota - 40 & 0,51 & 0,45 & 0,54 & 0,50 & 3 \\
\hline \multirow[t]{2}{*}{ XII } & Mary Dota - 41 & 0,52 & 0,47 & 0,52 & 0,50 & 3 \\
\hline & Mary Dota - 42 & & & & & 0 \\
\hline
\end{tabular}


TABELA 42.1 - Concentração de flúor na água das residências nos diferentes setores de abastecimento público, no mês de fevereiro, em Bauru, 2004

\begin{tabular}{|c|c|c|c|c|c|c|}
\hline $\begin{array}{l}\mathrm{N} \text { do } \\
\text { Setor }\end{array}$ & $\begin{array}{l}\text { Nome do Setor e Número } \\
\text { do Ponto de Coleta }\end{array}$ & $16 / f e v$ & $18 / f e v$ & 20/fev & Média & $\mathbf{n}$ \\
\hline & Cruzeiro do Sul - 43 & 0,55 & 0,56 & 0,67 & 0,59 & 3 \\
\hline \multirow[t]{3}{*}{ XIII } & Cruzeiro do Sul - 44 & 0,14 & 0,42 & 0,51 & 0,36 & 3 \\
\hline & Cruzeiro do Sul - 45 & 0,20 & 0,43 & 0,52 & 0,38 & 3 \\
\hline & Octávio Rasi - 46 & 0,71 & 0,85 & 0,68 & 0,75 & 3 \\
\hline \multirow[t]{3}{*}{ XIV } & Octávio Rasi - 47 & 0,81 & 0,54 & 0,65 & 0,67 & 3 \\
\hline & Octávio Rasi - 48 & 0,64 & 0,61 & 0,56 & 0,60 & 3 \\
\hline & Funcraf/Sta Terezinha - 49 & 0,63 & 0,55 & 0,61 & 0,60 & 3 \\
\hline \multirow[t]{3}{*}{$x V$} & Funcraf/Sta Terezinha - 50 & 0,62 & 0,56 & 0,58 & 0,59 & 3 \\
\hline & Funcraf/Sta Terezinha - 51 & 0,58 & 0,71 & 0,57 & 0,62 & 3 \\
\hline & Bauru $25-52$ & 0,61 & 0,54 & 0,59 & 0,58 & 3 \\
\hline \multirow[t]{3}{*}{ XVI } & Bauru $25-53$ & 0,58 & 0,55 & 0,59 & 0,57 & 3 \\
\hline & Bauru $25-54$ & -- & -- & -- & -- & 0 \\
\hline & Geisel II - 55 & 0,54 & 0,46 & 0,52 & 0,51 & 3 \\
\hline \multirow[t]{3}{*}{ XVII } & Geisel II - 56 & 0,57 & 0,45 & 0,54 & 0,52 & 3 \\
\hline & Geisel II - 57 & 0,54 & 0,50 & 0,54 & 0,53 & 3 \\
\hline & Nações - 58 & 0,58 & 0,52 & 0,59 & 0,56 & 3 \\
\hline \multirow[t]{3}{*}{ XVIII } & Nações - 59 & 0,56 & 0,48 & 0,56 & 0,53 & 3 \\
\hline & Nações - 60 & 0,49 & 0,45 & 0,49 & 0,48 & 3 \\
\hline & Samambaia - 61 & 0,61 & 0,47 & 0,59 & 0,56 & 3 \\
\hline \multirow[t]{3}{*}{ XIX } & Samambaia - 62 & 0,57 & 0,51 & 0,51 & 0,53 & 3 \\
\hline & Samambaia - 63 & 0,51 & 0,46 & 0,52 & 0,50 & 3 \\
\hline & & & & & Total & 173 \\
\hline
\end{tabular}

TABELA 43 - Classificação das amostras de água de acordo com o teor de flúor, dos diferentes setores de abastecimento de Bauru, no mês de fevereiro de 2004

\begin{tabular}{cccc}
\hline Teor de flúor & $\mathbf{n}$ & $\%$ & Classificação \\
\hline $01-0,55 \mathrm{mg} / \mathrm{L}$ & 88 & 51 & Inaceitável \\
$0,55-0,65 \mathrm{mg} / \mathrm{L}$ & 59 & 34 & Sub-ótima \\
$0,65-0,75 \mathrm{mg} / \mathrm{L}$ & 16 & 9 & Ótima \\
$0,75-0,85 \mathrm{mg} / \mathrm{L}$ & 6 & 4 & Supra-ótima \\
$0,85-1,15 \mathrm{mg} / \mathrm{L}$ & 4 & 2 & Inadequada \\
$1,15 \models$ acima & 0 & 0 & Inaceitável \\
\hline Total & $\mathbf{1 7 3}$ & $\mathbf{1 0 0}$ & \\
\hline
\end{tabular}




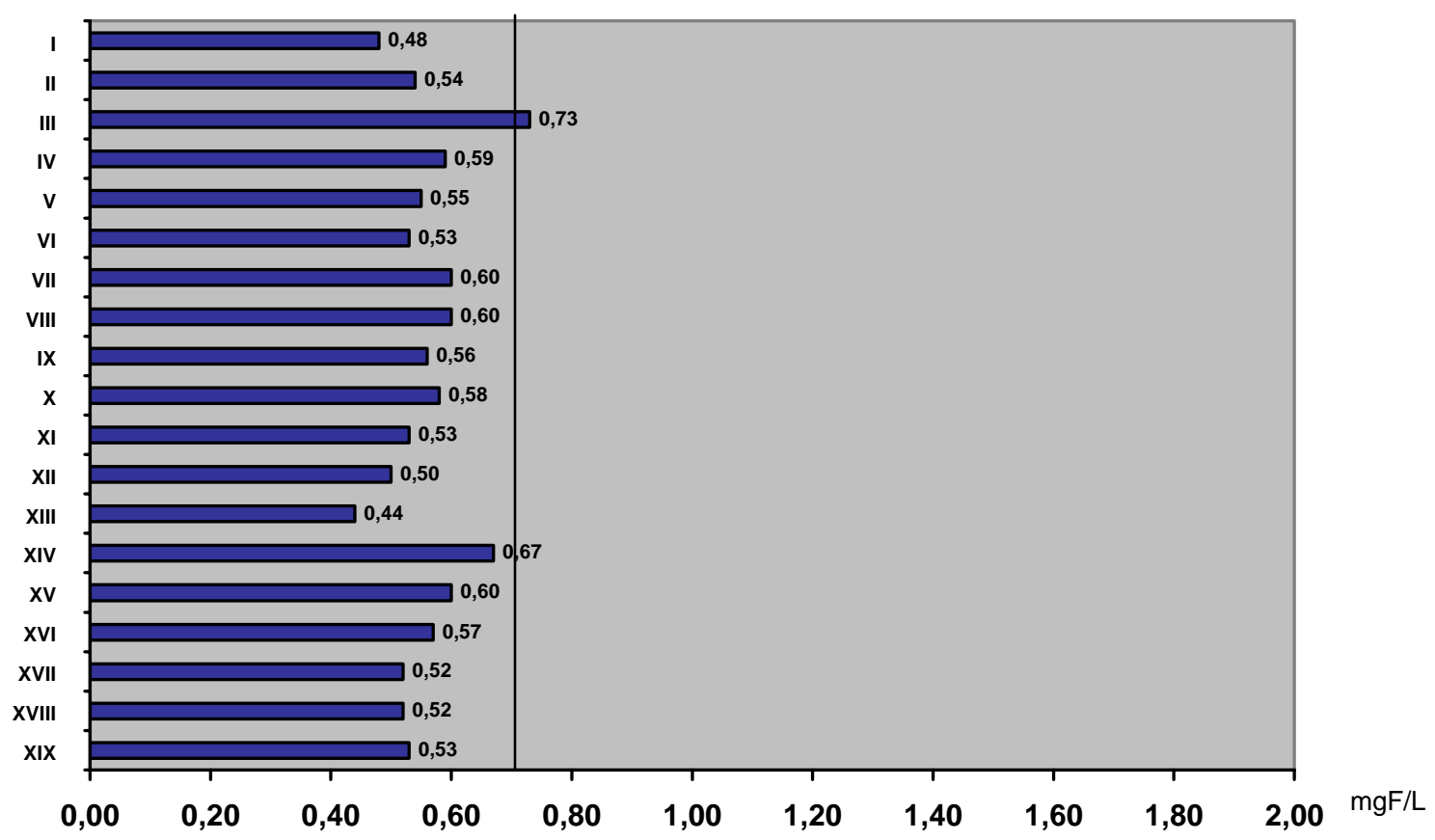

FIGURA 30 - Concentração média de flúor, nos diferentes setores de abastecimento de Bauru, no mês de fevereiro de 2004

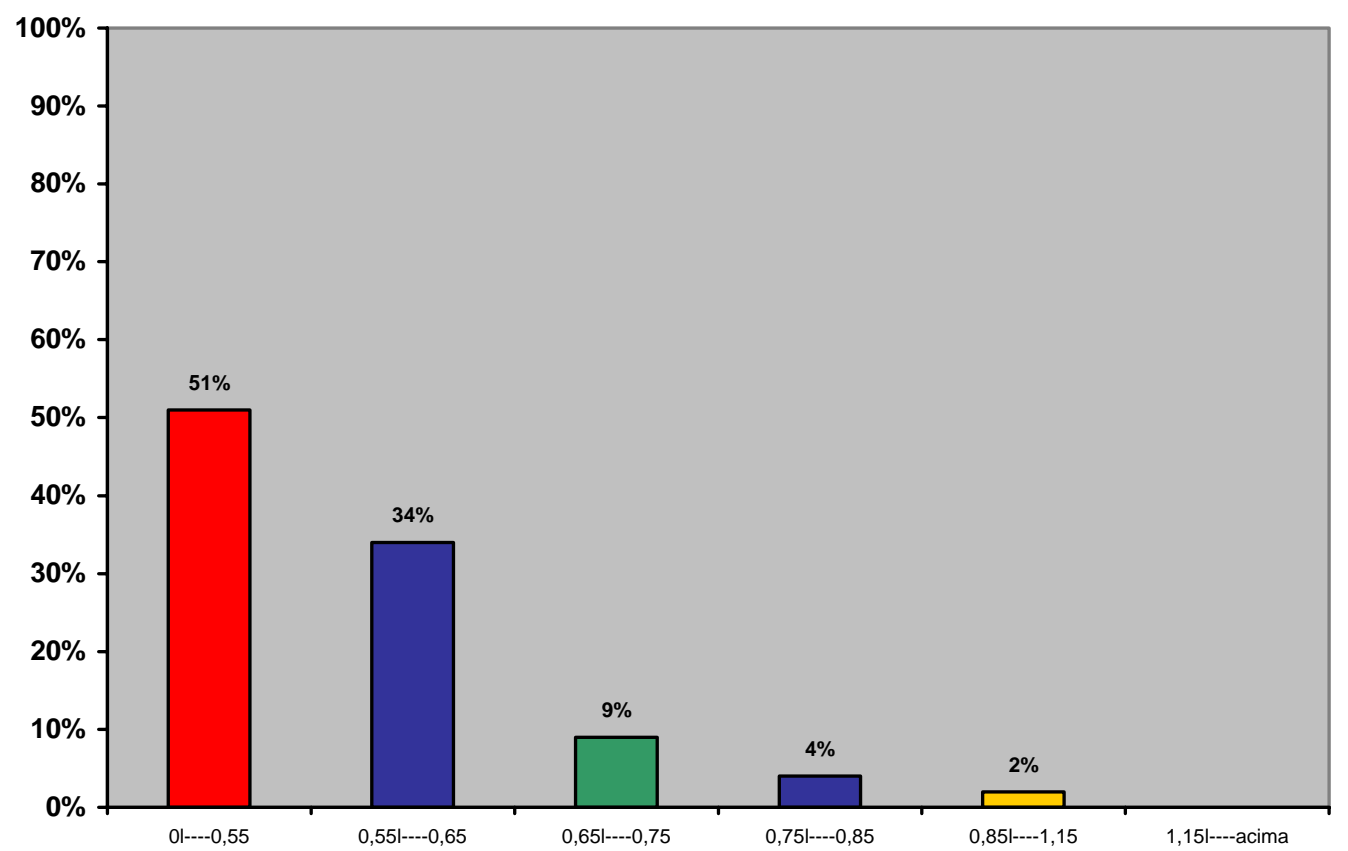

FIGURA 31 - Classificação das amostras de água de acordo com a concentração de flúor nos diferentes setores de abastecimento de Bauru, no mês de fevereiro de 2004 
TABELA 44 - Concentração de flúor na água das residências nos diversos setores de abastecimento público, nos meses de maio, agosto e novembro de 2003 e de fevereiro de 2004, em Bauru

\begin{tabular}{|c|c|c|c|c|c|c|c|}
\hline $\begin{array}{l}\mathrm{N} \text { do } \\
\text { Setor }\end{array}$ & $\begin{array}{l}\text { Nome do Setor e Número do } \\
\text { Ponto de Coleta }\end{array}$ & mai & ago & nov & fev & Média & $\mathbf{n}$ \\
\hline & ETA - 1 & 0,54 & 0,51 & 0,76 & 0,49 & 0,58 & 12 \\
\hline & ETA - 2 & 0,52 & 0,43 & 0,78 & 0,48 & 0,55 & 12 \\
\hline \multirow[t]{5}{*}{$\mathbf{I}$} & ETA - 3 & 0,53 & 0,51 & 0,77 & 0,49 & 0,58 & 12 \\
\hline & ETA - 4 & 0,54 & 0,58 & 0,82 & 0,51 & 0,61 & 12 \\
\hline & ETA - 5 & 0,46 & 0,48 & 0,78 & 0,46 & 0,55 & 12 \\
\hline & ETA - 6 & 0,51 & 0,48 & 0,79 & 0,48 & 0,57 & 12 \\
\hline & Parque Real I e Real II - 7 & 0,66 & 0,86 & 0,57 & 0,84 & 0,73 & 12 \\
\hline \multirow[t]{3}{*}{ II } & Parque Real I e Real II - 8 & -- & 0,55 & 0,13 & 0,10 & 0,26 & 9 \\
\hline & Parque Real I e Real II - 9 & 0,71 & 0,52 & 0,70 & 0,69 & 0,66 & 12 \\
\hline & Bauru 16 - 10 & 0,77 & 0,72 & 0,71 & -- & 0,73 & 9 \\
\hline \multirow[t]{3}{*}{ III } & Bauru 16 - 11 & -- & 0,63 & 0,72 & 0,73 & 0,69 & 8 \\
\hline & Bauru 16 - 12 & 0,81 & 0,72 & 0,72 & -- & 0,75 & 9 \\
\hline & Nova Esperança/Jaraguá - 13* & 0,54 & -- & 0,78 & 0,61 & 0,64 & 8 \\
\hline \multirow[t]{3}{*}{ IV } & Nova Esperança/Jaraguá - 14* & 0,63 & 0,63 & 0,13 & 0,58 & 0,49 & 9 \\
\hline & Nova Esperança/Jaraguá - 15* & 0,67 & 0,51 & 0,70 & 0,58 & 0,62 & 12 \\
\hline & Industrial III/Roosevelt II- 16 & 0,85 & 0,60 & 0,75 & 0,56 & 0,69 & 12 \\
\hline \multirow[t]{3}{*}{ V } & Industrial III/Roosevelt II - 17 & 0,82 & 0,60 & 0,76 & 0,56 & 0,69 & 12 \\
\hline & Industrial III/Roosevelt II - 18 & 0,72 & 0,59 & 0,76 & 0,55 & 0,66 & 12 \\
\hline & Vânia Maria - 19 & 0,71 & 0,57 & 0,76 & 0,54 & 0,65 & 12 \\
\hline \multirow[t]{3}{*}{ VI } & Vânia Maria - 20 & 0,88 & 0,56 & 0,75 & 0,53 & 0,68 & 12 \\
\hline & Vânia Maria - 21 & 0,79 & 0,59 & 0,77 & 0,53 & 0,67 & 12 \\
\hline & Bíblia/Padilha/Consolação - 22 & 0,52 & 0,54 & 0,73 & 0,59 & 0,60 & 12 \\
\hline \multirow[t]{3}{*}{ VII } & Bíblia/Padilha/Consolação - 23 & 0,91 & 0,57 & 0,79 & 0,62 & 0,72 & 12 \\
\hline & Bíblia/Padilha/Consolação - 24 & 0,48 & 0,52 & 0,74 & 0,61 & 0,59 & 12 \\
\hline & Primavera/Beija Flor - 25 & 0,79 & 0,52 & 0,77 & 0,60 & 0,67 & 12 \\
\hline \multirow[t]{3}{*}{ VIII } & Primavera/Beija Flor - 26 & 0,78 & 0,32 & 0,75 & 0,58 & 0,61 & 12 \\
\hline & Primavera/Beija Flor - 27 & 0,71 & 0,52 & 0,78 & 0,64 & 0,66 & 12 \\
\hline & Cecília/Garrafa/Beija Flor - 28 & 0,66 & 0,51 & 0,81 & 0,58 & 0,64 & 12 \\
\hline \multirow[t]{3}{*}{ IX } & Cecília/Garrafa/Beija Flor - 29 & 0,79 & 0,38 & 0,74 & 0,54 & 0,61 & 12 \\
\hline & Cecília/Garrafa/Beija Flor- 30 & 0,72 & 0,31 & -- & -- & 0,52 & 6 \\
\hline & Gasparini/Beija Flor - 31 & 0,37 & 0,56 & 0,78 & 0,56 & 0,57 & 11 \\
\hline \multirow[t]{3}{*}{$\mathbf{x}$} & Gasparini/Beija Flor - 32 & 0,70 & -- & -- & 0,58 & 0,64 & 6 \\
\hline & Gasparini/Beija Flor - 33 & 0,69 & 0,51 & 0,78 & 0,61 & 0,65 & 12 \\
\hline & Lotes Urbanizados/Po - 34 & 0,18 & 0,70 & 0,43 & 0,59 & 0,48 & 12 \\
\hline \multirow[t]{3}{*}{ XI } & Lotes Urbanizados/Po - 35 & 0,36 & -- & 0,56 & 0,54 & 0,49 & 9 \\
\hline & Lotes Urbanizados/Po - 36 & 0,26 & 0,61 & 0,51 & 0,49 & 0,47 & 12 \\
\hline & Lotes Urbanizados/No - 37 & 0,32 & 0,63 & 0,49 & 0,49 & 0,48 & 12 \\
\hline \multirow[t]{3}{*}{ XI } & Lotes Urbanizados/No - 38 & 0,29 & 0,60 & 0,46 & 0,55 & 0,48 & 12 \\
\hline & Lotes Urbanizados/No - 39 & 0,20 & 0,62 & 0,50 & 0,57 & 0,47 & 12 \\
\hline & Mary Dota - 40 & 0,64 & 0,60 & 0,78 & 0,50 & 0,63 & 12 \\
\hline \multirow[t]{2}{*}{ XII } & Mary Dota - 41 & 0,63 & 0,59 & 0,77 & 0,50 & 0,62 & 12 \\
\hline & Mary Dota - 42 & 0,65 & 0,58 & 0,79 & -- & 0,67 & 9 \\
\hline
\end{tabular}


TABELA 44.1 - Concentração de flúor na água das residências nos diversos setores de abastecimento público, nos meses de maio, agosto e novembro de 2003 e de fevereiro de 2004, em Bauru

\begin{tabular}{|c|c|c|c|c|c|c|c|}
\hline $\begin{array}{l}\mathrm{N} \text { do } \\
\text { Setor }\end{array}$ & $\begin{array}{l}\text { Nome do Setor e Número do } \\
\text { Ponto de Coleta }\end{array}$ & mai & ago & nov & fev & Média & $\mathbf{n}$ \\
\hline & Cruzeiro do Sul - 43 & 0,65 & 0,57 & 0,61 & 0,59 & 0,61 & 12 \\
\hline \multirow[t]{3}{*}{ XIII } & Cruzeiro do Sul - 44 & 0,62 & 0,58 & 0,77 & 0,36 & 0,58 & 12 \\
\hline & Cruzeiro do Sul - 45 & 0,60 & 0,55 & 0,63 & 0,38 & 0,54 & 12 \\
\hline & Octávio Rasi - 46 & 0,87 & 0,61 & 0,87 & 0,75 & 0,78 & 11 \\
\hline \multirow[t]{3}{*}{ XIV } & Octávio Rasi - 47 & 0,87 & 0,41 & 0,81 & 0,67 & 0,69 & 11 \\
\hline & Octávio Rasi - 48 & 0,85 & 0,51 & 0,84 & 0,60 & 0,70 & 10 \\
\hline & Funcraf/Sta Terezinha - 49** & 0,65 & 0,52 & 0,65 & 0,60 & 0,61 & 12 \\
\hline \multirow[t]{3}{*}{$X V$} & Funcraf/Sta Terezinha - $50^{\star *}$ & 0,67 & 0,54 & 0,66 & 0,59 & 0,62 & 12 \\
\hline & Funcraf/Sta Terezinha - $51^{\star *}$ & 0,66 & 0,54 & 0,66 & 0,62 & 0,62 & 12 \\
\hline & Bauru $25-52$ & 0,60 & -- & 0,81 & 0,58 & 0,66 & 8 \\
\hline \multirow[t]{3}{*}{$\mathrm{XVI}$} & Bauru $25-53$ & 0,59 & 0,58 & 0,84 & 0,57 & 0,65 & 12 \\
\hline & Bauru 25 - 54 & 0,61 & -- & -- & -- & 0,61 & 3 \\
\hline & Geisel II - 55 & 0,63 & 0,53 & 0,73 & 0,51 & 0,60 & 12 \\
\hline \multirow[t]{3}{*}{ XVII } & Geisel II - 56 & 0,63 & 0,57 & 0,67 & 0,52 & 0,60 & 12 \\
\hline & Geisel II - 57 & 0,60 & 0,60 & 0,74 & 0,53 & 0,62 & 12 \\
\hline & Nações - 58 & 0,70 & 0,57 & 0,75 & 0,56 & 0,65 & 12 \\
\hline \multirow[t]{3}{*}{ XVIII } & Nações - 59 & 0,67 & 0,55 & 0,76 & 0,53 & 0,63 & 11 \\
\hline & Nações - 60 & 0,55 & 0,50 & 0,78 & 0,48 & 0,58 & 12 \\
\hline & Samambaia - 61 & 0,61 & 0,52 & 0,78 & 0,56 & 0,62 & 12 \\
\hline \multirow[t]{3}{*}{ XIX } & Samambaia - 62 & 0,52 & 0,48 & -- & 0,53 & 0,51 & 9 \\
\hline & Samambaia - 63 & 0,61 & 0,49 & 0,75 & 0,50 & 0,59 & 12 \\
\hline & & & & & & Total & 697 \\
\hline
\end{tabular}

TABELA 45 - Classificação das amostras de água de acordo com o teor de flúor, dos diferentes setores de abastecimento de Bauru, nos meses maio, agosto e novembro de 2003 e no mês de fevereiro de 2004

\begin{tabular}{|c|c|c|c|}
\hline Teor de flúor & $\mathbf{n}$ & $\%$ & Classificação \\
\hline $0 \vdash 0,55 \mathrm{mg} / \mathrm{L}$ & 240 & 34 & Inaceitável \\
\hline $0,55 \longmapsto 0,65 \mathrm{mg} / \mathrm{L}$ & 178 & 26 & Sub-ótima \\
\hline $0,65 \vdash 0,75 \mathrm{mg} / \mathrm{L}$ & 118 & 17 & Ótima \\
\hline $0,75 \vdash 0,85 \mathrm{mg} / \mathrm{L}$ & 130 & 19 & Supra-ótima \\
\hline $0,85 \longmapsto 1,15 \mathrm{mg} / \mathrm{L}$ & 30 & 4 & Inadequada \\
\hline $1,15 \vdash$ acima & 1 & 0 & Inaceitável \\
\hline Total & 697 & 100 & \\
\hline
\end{tabular}




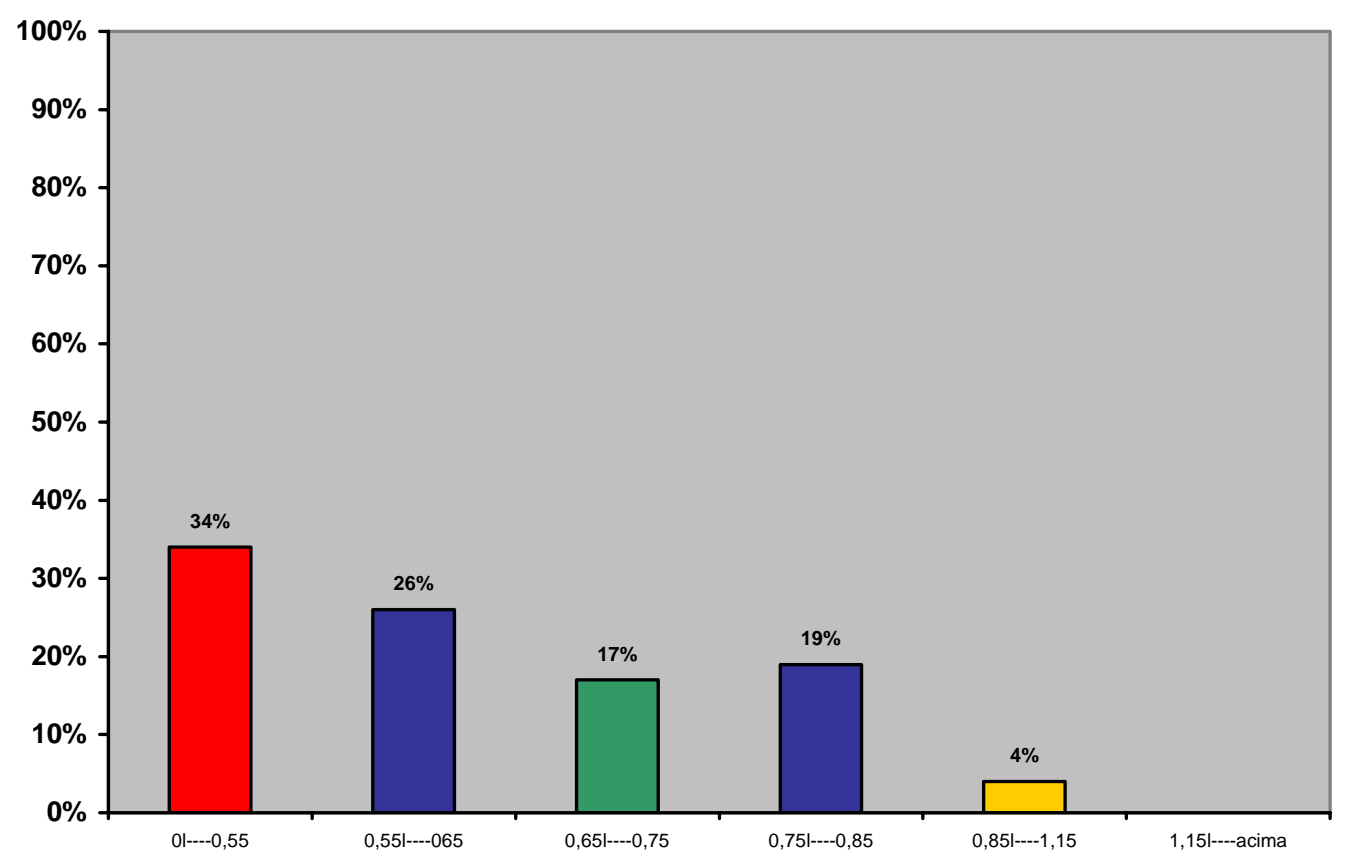

FIGURA 32 - Classificação das amostras de água de acordo com a concentração de flúor nos diferentes setores de abastecimento de Bauru, nos meses de maio, agosto e novembro de 2003 e fevereiro de 2004 
6 DiscussÃo 


\section{DISCUSSÃo}

A concentração de flúor naturalmente presente na água de abastecimento, a partir da qual se pode verificar algum efeito favorável sobre a prevalência de cárie, segundo VIEGAS, é de 0,4 mg F/L (VIEGAS ${ }^{137}$, 1961), e CASTELLANOS, preconize 0,5 mg F/L (NARVA $\left.{ }^{98}, 2001\right)$.

No Estado de São Paulo, existem registros de 52 municípios que abastecem parte ou toda sua população com água naturalmente fluoretada. Nestes municípios o teor de flúor natural varia entre 0,4 a $12 \mathrm{mg} / \mathrm{L}$. Os municípios que possuem flúor natural em suas águas, dependendo da concentração, precisam disponibilizar soluções técnicas para a normalização desta concentração, dentro dos padrões recomendados. Os teores superiores a 1,2 mg/L são ajustados na Estação de Tratamento de Água, à exceção do município de Pereiras, com $6,5 \mathrm{mg} F / L$, onde a água não é classificada como potável, não sendo, assim, recomendada para o consumo pela população. Portanto, existem municípios em que apenas parte da população é abastecida com água naturalmente fluoretada, como Araçatuba, onde $20 \%$ da população recebe água com flúor natural e o restante com flúor adicionado na ETA, durante o processo de tratamento e distribuição de água. Para os municípios nos quais a água naturalmente fluoretada abastece a totalidade da população urbana e rural, o procedimento técnico é simplificado, bastando o monitoramento dos teores de flúor de acordo com a sazonalidade da região $\left(C A L V O{ }^{36}, 1996\right)$.

Além da região Sudeste, no Brasil, outras regiões também apresentam importantes concentrações de flúor natural na água (MALTZ; 
FARIAS ${ }^{86}, 1998$; SAMPAIO et al. ${ }^{117}$, 2000; SANTOS et al. ${ }^{120}$, 2003). Os mesmos aspectos são considerados em outros países, por exemplo a cidade de Los Angeles, nos EUA, onde $75 \%$ da população é abastecida com água apresentando uma concentração de flúor natural variando entre, 0,4 a 1 mg $\mathrm{F} / \mathrm{L}$, com uma média de 0,56 mg/L. As variações ocorrem durante alguns meses do ano e são de curta duração (SPEARS $\left.{ }^{128}, 1991\right)$. Da mesma forma um alto, conteúdo de flúor natural, em torno de $5 \mathrm{mg} / \mathrm{L}$, é observado em algumas regiões do Srilanka, geralmente em áreas da zona climática conhecida como "zona seca" (EKANAYAKE; HOEK6 ${ }^{56}$ 2002).

O flúor naturalmente presente na água de abastecimento público de Bauru, apresenta-se em baixas concentrações (abaixo de 0,4 mg/L). Com o protocolo proposto para a pesquisa, objetivou-se avaliar também a ocorrência de possíveis variações nesta concentração sob a influência da sazonalidade da região. Esta influência, quando ocorre, é de fundamental importância para que se possa calcular a quantidade de flúor a ser adicionado à água de abastecimento, observando a concentração natural de flúor. Outro aspecto da sazonalidade é o consumo maior ou menor de água, em função das altas ou baixas temperaturas. As 318 amostras de água coletadas na ETA e nos poços, antes da fluoretação, ou seja, para avaliar a concentração de flúor naturalmente presente na água do manancial de águas superficiais do Rio Batalha (ETA) e do manancial de águas subterrâneas do Aqüífero Guarani, não apresentaram variações importantes na média, durante o período de coleta (TABELA 25). Vale salientar que entre as concentrações verificadas, a mais baixa foi a do poço Garrafa, 0,04 mg 
F/L (TABELA 23) e a mais alta foi a do poço Samambaia, 0,22 mg F/L (TABELA 21).

Alguns dados relevantes merecem ser comentados, até para um melhor entendimento de alguns aspectos do sistema de fluoretação de Bauru, bem como de algumas concentrações elevadas, verificadas na água, que a princípio, deveria apresentar uma concentração de flúor inferior a 0,4 mg/L. Mediante a análise das amostras de água, no poço Parque Real I as concentrações mais altas, fora da margem de valores considerada como normal para Bauru, variaram de 0,87 (TABELA 22) a 6,68 mg F/L (TABELA 24). Os valores encontrados na água do poço Parque Real I, não correspondem à real concentração de flúor naturalmente presente na água. Esta afirmação é feita com base nos dados obtidos das amostras de água do mesmo poço após a fluoretação, que apresentaram valores pouco acima. Além disso, a coleta das amostras de água já fluoretada era feita no mesmo ponto de coleta de água não fluoretada, pela falta de um ponto para a coleta da água natural antes do procedimento da fluoretação. Talvez a manobra executada pelo funcionário do DAE não tenha sido realizada com o intervalo de tempo necessário, para se obter uma água natural. Após o procedimento de desligar a bomba dosadora de flúor, aguardava-se cerca de 3 minutos para a coleta da amostra, com a água jorrando da tubulação. Certamente o tempo deveria ser maior. Outros dados que indicam uma falsa "alta" concentração de flúor natural na água, são os resultados da análise das amostras coletadas nas residências do setor abastecido pelos poços Parque Real I e Parque Real II (Setor II), consideradas dentro dos teores aceitáveis (TABELAS, 36, 36.1, 37, 38, 38.1, 39, 40, 40.1, 41, 42, 42.1, 43). 
O maior problema identificado com o poço Parque Real I não está relacionado ao flúor naturalmente presente na água, mas sim, ao adicionado. Este fato será discutido a seguir, quando forem abordados os resultados obtidos com a análise da água coletada imediatamente após a fluoretação na ETA e nos poços.

Ainda com relação ao flúor natural, além do poço Parque Real I, no poço Santa Terezinha também houve erro na definição do ponto de coleta, feita pelo funcionário do DAE. As amostras expressaram a concentração de flúor alcançada após a fluoretação. Se comparados os valores do teor de flúor do poço Santa Terezinha, obtidos para a água antes da fluoretação, com os verificados após a fluoretação, que é realizada juntamente com a água do poço Funcraf, pode-se perceber que são muito próximos e em alguns casos, iguais (TABELAS 23, 24, 30 e 31). Portanto, na verdade a água coletada e analisada, correspondia à água artificialmente fluoretada.

Além destes, outros resultados chamaram a atenção, com valores particularmente elevados. No poço Bauru 16, o valor encontrado foi de 2,29 mg F/L (TABELA 23), no poço Parque Real II, 3,48 mg F/L, e no Bauru 25, 12,70 mg F/L (TABELA 24), sem que uma explicação técnica tenha sido dada.

Os dados obtidos indicam que a água captada tanto do Rio Batalha (ETA), quanto do Aqüífero Guarani (27 poços), não apresenta variação na concentração de flúor naturalmente presente em decorrência da sazonalidade própria de cada uma das estações do ano (TABELAS 21, 22, 23, 24), nem tão pouco existe diferença entre a água da ETA e dos poços. 
No entanto, verificou-se que o poço que apresentou, de forma constante, a mais alta concentração de flúor natural foi o Industrial III (média final=0,13 mg/L), enquanto que a mais baixa, foi constatada no poço Garrafa (média final=0,05 mg/L) (TABELA 25).

Para que uma medida seja adotada em saúde pública na prevenção de doenças, esta deve preencher alguns requisitos básicos. As características que fazem da fluoretação da água de abastecimento público uma grande medida de saúde pública na prevenção da doença cárie, quando implantada, são sua segurança, efetividade na prevenção da cárie, facilidade de administração, baixo custo e sua abrangência populacional (HOROWITZ ${ }^{74}$, 1996). No entanto, uma série de problemas dificulta a sua manutenção, como a manutenção minuciosa dos equipamentos, monitoramento constante do teor de flúor adicionado, programas de treinamento para os operadores dos equipamentos além de outros (HOROWITZ $^{73}$, 1990; CURY ${ }^{49}$, 1992; MURRAY ${ }^{93}$, 1992; BASTOS; LOPES; FREITAS $^{12}$, 1993; MODESTO et al. ${ }^{92}, 1997$ CURY $\left.^{50}, 2001\right)$.

Embora nem todos os segmentos da população tenham acesso aos benefícios da fluoretação, por outro lado, tem-se observado um aumento na prevalência e, em uma menor extensão, na intensidade da fluorose dentária em ambas as comunidades, adequadamente fluoretada ou não. Estas constatações não surpreendem quando consideradas todas as fontes adicionais de ingestão de flúor disponíveis atualmente (1996), que não existiam nas décadas de 40 e 50 quando se introduziu a fluoretação (HOROWITZ ${ }^{74}$, 1996; MALTZ et al. ${ }^{87}$, 2000; PEREIRA et al. ${ }^{108}$, 2001). Além destes, um outro aspecto a ser considerado é a mudança considerável dos 
hábitos alimentares das crianças, tendo aumentado o consumo de alimentos e bebidas processados industrialmente com água fluoretada (BUZALAF ${ }^{35}$, 2002). O aumento na prevalência da fluorose dentária tem sido associado essencialmente ao uso precoce de dentifrícios fluoretados, uso indiscriminado de suplementos fluoretados na dieta e o consumo prolongado de fórmulas infantis (HOROWITZ ${ }^{74}, 1996$; PEREIRA et al. $\left.{ }^{108}, 2001\right)$. Estimase que mais de $60 \%$ da fluorose observada atualmente é conseqüência da ingestão das diferentes fontes de flúor, que não a água de abastecimento público (LEWIS; BANTING $\left.{ }^{82}, 1994\right)$.

Quando analisadas as amostras de água da ETA e dos poços imediatamente após a fluoretação, constatou-se que a concentração de flúor naturalmente presente não interferiu na concentração de flúor após a fluoretação, ou seja, o poço Industrial III não foi o que apresentou a maior concentração de flúor e tão pouco o Garrafa, manteve a menor.

O poço Parque Real I apresenta uma situação singular e muito preocupante. As amostras de água fluoretada apresentaram uma concentração de flúor elevada, acima do limite máximo aceitável, variando entre 1,58 a 6,23 mg F/L, sendo que estas correspondem aos meses de agosto e fevereiro respectivamente (TABELA 34). Embora conste que o Setor II é abastecido pelos poços Parque Real I e Parque Real II, uma parcela pequena da população deste setor é abastecida exclusivamente pelo Parque Real I, até que suas águas se encontrem com as do Parque Real II. O poço Parque Real II não tem bomba dosadora de flúor e de cloro e, sendo assim, é adotado o seguinte procedimento, a água do poço Parque Real I é clorada e fluoretada com o dobro ou um pouco mais do teor de cloro e flúor 
recomendado, e quando suas águas encontram com as do poço Parque Real II, já sendo distribuída para a população, estas são cloradas e fluoretadas (FIGURAS 15, 17, 19, 21). Mas como fica a população moradora desta pequena área, com cerca de 150 casas e com muitas crianças? Medidas urgentes devem ser adotadas. Foi realizado um monitoramento durante uma semana, com coletas de amostras de água na segunda, quarta e sexta-feira, totalizando 50 amostras. Para complementar as informações, foi realizado o levantamento epidemiológico de fluorose dentária com as crianças entre 7 e 15 anos de idade, empregando o índice TF. Os dados estão em fase de tabulação e assim que os resultados forem definidos serão encaminhados para o DAE e Secretaria Municipal de Saúde, a fim de alertar as autoridades com relação às condições de fluoretação da água no local.

Embora em outros poços seja adotado o sistema de fluoretação conjunta de águas, o caso do Padilha/Consolação, Santa Cecília/Garrafa e Funcraf/Santa Terezinha, esta estratégia não apresenta problemas, uma vez que se dá nos reservatórios, para posterior distribuição à população (FIGURAS 15, 17, 19, 21). Com valores menos alarmantes, embora também altos, as amostras do poço Octávio Rasi resultaram em uma média final de 0,91 mg F/L, classificada como inadequada (TABELA 34).

Quando analisada a classificação das amostras coletadas, do total de 297, cerca de $18 \%$ foram classificadas como inaceitáveis, por apresentarem uma concentração de flúor muito baixa e 4\% muito alta. Portanto, 22\% das amostras estão fora dos padrões considerados aceitáveis (TABELA 35 e FIGURA 23). Alguns poços mostraram uma tendência dominante de subfluoretação, tendo suas águas classificadas como 
inaceitáveis segundo sua concentração de flúor, o caso do Lotes Padilha/Consolação, Santa Cecília/Garrafa, Urbanizados, Cruzeiro do Sul e a ETA (TABELA 34). As amostras da ETA, surpreendentemente apresentaram uma das menores concentrações de flúor. Na ETA fica instalado o laboratório de análises químicas da água de abastecimento público de Bauru, o que favorece correções mediante a constatação de teores inadequados de flúor. Portanto, o esperado era que suas águas apresentassem os melhores teores de flúor.

Nos meses de maio e agosto de 2003 foram constatadas as mais baixas concentrações de flúor e em maior freqüência, 32\% e 27\%, respectivamente (FIGURAS 16 e 18). Nos meses de novembro e fevereiro, quando coerentemente eram esperadas concentrações mais baixas de flúor, em função das altas temperaturas e conseqüente maior consumo de água, ocorreu o inverso. As concentrações verificadas foram as mais altas, sendo que no mês de novembro de 2003, aproximadamente $83 \%$ das amostras foram classificadas entre sub-ótima (4\%), ótima (36\%) e supra-ótima (43\%) (FIGURA 23). No mês de fevereiro de 2004, cerca de $88 \%$ das amostras foram classificadas como aceitáveis, onde 3\% como supra-ótima, 59\% como sub-ótima e 26\% como ótima (FIGURA 20 e 22). Além de haver uma oscilação grande na concentração de flúor na ETA e nos poços entre uma estação do ano e outra, esta está acontecendo inversamente ao indicado. Estes dados são importantes quando consideramos o mecanismo de ação do flúor.

Com base nas informações de levantamentos epidemiológicos, que estão de acordo com as pesquisas realizadas em laboratórios sobre a 
fluoretação da água e administração de flúor pós-eruptivo, é possível concluir que a adição regular de pequenas quantidades de flúor na boca, desde a erupção dentária, reduz o índice de cárie em cerca de 50\% (THYLSTRUP $\left.{ }^{134}, 1990\right)$. Este conceito da dinâmica de redução da cárie é baseado em pesquisas sobre o efeito do flúor durante a ocorrência da desmineralização, onde as elevações freqüentes nos níveis de flúor na boca reduzem a perda de mineral, reduzindo a progressão da lesão de cárie (THYLSTRUP ${ }^{134}, 1990 ;$ ASSIS et al. $\left.{ }^{5}, 1999\right)$. O consumo de água fluoretada não fornece apenas uma fonte de flúor tópico quando a água é ingerida, mas também quando o flúor circula pela boca através da saliva (THYLSTRUP ${ }^{134}$, 1990; HOROWITZ ${ }^{74}$, 1996; ASSIS et al. ${ }^{5}$, 1999; WHITFORD ${ }^{149}$, 2002).

Para avaliar a importância relativa ao consumo de água fluoretada no período pré e pós-eruptivo, é relevante examinar as informações clínicas de estudos onde as crianças foram examinadas em diferentes períodos. A significância da ação do flúor está centrada na sua ação pós-eruptiva, eminentemente tópica (THYLSTRUP $\left.{ }^{134}, 1990\right)$. Considerando que todas as crianças do estudo Grand Rapids, de até 14 anos de idade, nasceram na cidade após a fluoretação ter sido implantada, é possível concluir que a quantidade de flúor presente na água consumida foi capaz de reduzir o índice de cárie em dentes em erupção, durante o período do estudo (15 anos), em cerca de 50\% (THYLSTRUP ${ }^{134}$, 1990). Em Bauru, após 15 anos de fluoretação, o índice CPO-D médio para as crianças de 12 anos de idade declinou cerca de 60\% (9,89 em 1976 e 3,97 em 1990) (BASTOS; FREITAS ${ }^{11}$, 1991). Valores semelhantes foram observados em Campinas 
(VIEGAS; VIEGAS $\left.{ }^{139}, 1985\right)$, Barretos (VIEGAS; VIEGAS $\left.{ }^{141}, 1988\right)$ e Piracicaba (BASTING; PEREIRA; MENEGHIM ${ }^{10}$, 1997).

Desta forma, o flúor normalmente presente na placa dentária devido à fluoretação da água (flúor tópico) não é capaz de prevenir completamente a ocorrência de cárie, mas reduz em torno de 50\%. Sendo assim, a fluoretação é considerada uma medida econômica, capaz de reduzir a cárie de uma comunidade em 50\%, e ainda, altamente efetiva do ponto de vista do administrador de saúde, pois um indivíduo recebe um composto de flúor que pode oferecer $50 \%$ de proteção para a doença cárie (THYLSTRUP $\left.{ }^{134}, 1990\right)$.

Vale salientar ainda que, em uma população abastecida com água fluoretada, a concentração de flúor na placa durante grande parte do dia não é significativamente aumentada pelo uso de dentifrício fluoretado. Não está totalmente estabelecido porque os dentifrícios fluoretados, cujas concentrações de flúor normalmente variando entre 900 a 1000 mg/Kg, não têm mostrado serem mais efetivos que a água fluoretada na prevenção à cárie dentária. Com base em considerações de dose-resposta, seria esperado que o uso regular de dentifrícios produzisse concentrações de flúor na placa consideravelmente maiores e que, teoricamente, desencadearia em um efeito cariostático maior. Embora as concentrações de flúor na placa e na saliva aumentem bruscamente durante o uso de um dentifrício ou enxaguatório fluoretados, ocorre um declínio rápido, havendo uma aproximação ou mesmo a tendência de se igualar às concentrações basais, dentro de 1 a 2 horas. Assim, em uma região abastecida com água fluoretada, pode ser que, apesar de uma ou mais elevações transitórias na 
concentração de flúor que aconteçam durante o dia, de acordo com a freqüência do uso do dentifrício de cada indivíduo, as concentrações de flúor durante a maior parte do dia são similares, independente do uso de dentifrício fluoretado (WHITFORD et al. ${ }^{149}$, 2002). Provavelmente, a maior eficiência na utilização diária de dentifrício fluoretado se deve ao fato deste procedimento possibilitar, ao mesmo tempo, o controle da placa bacteriana associado à aplicação tópica de flúor (THYLSTRUP $\left.{ }^{134}, 1990\right)$. Os efeitos cariostáticos da água e do dentifrício fluoretados são similares (WHITFORD et al. $\left.{ }^{149}, 2002\right)$.

Os resultados obtidos da análise das 697 amostras, dos diferentes setores de abastecimento (FIGURAS 24, 26, 28 e 30) não difere muito daqueles verificados com as águas coletas nos poços (FIGURAS 15,17,19 e 21) e tão pouco de outros estudos desenvolvidos para analisar a fluoretação em Bauru (NAGEM FILHO et al. ${ }^{94}$, 1997; TAVARES; BASTOS ${ }^{129}$, 1999; BUZALAF et al. ${ }^{34}$, 2002; LODI; RAMIRES; BASTOS $^{85}$, 2003) e em outras cidades (VERTUAN ${ }^{136}$, 1986; BARROS; TOVO; SCAPINI ${ }^{8}, 1990 ;$ BARROS; $^{2}$ SCAPINI; TOVO ${ }^{9}, 1993$; FERREIRA et al. ${ }^{63}, 1999$; MODESTO et al. ${ }^{92}$, 1999; WERNER $\left.{ }^{142}, 1999\right)$, nos quais observou-se a dificuldade na manutenção da concentração de flúor dentro dos teores recomendados.

No setor II, abastecido pelos poços Parque Real I e II, as concentrações verificadas no mês de maio apresentaram-se dentro dos limites aceitáveis (TABELA 36 e FIGURA 24). No mesmo mês, a análise das amostras de água do setor XI mostrou valores que indicam oscilações muito grandes, entre 0,09 e 0,51 mg F/L, sugerindo a interrupção da fluoretação. No setor XII, no mesmo mês as variações foram ainda maiores, entre 0,10 e 
0,93 mg F/L. As hipóteses são várias, mas estes resultados podem indicar fundamentalmente, uma descontinuidade na fluoretação, inclusive num mesmo dia (FIGURA 24). Cerca de 31\% das amostras do mês de maio foram classificadas como inaceitáveis pela baixa concentração de flúor, 11\% inadequada pela alta concentração e 58\%, entre os limites mínimo e máximo aceitáveis (TABELA 37 e FIGURA 25 ).

Através dos resultados obtidos com a análise das amostras do mês de agosto, observa-se que houve uma baixa generalizada na concentração de flúor em relação ao mês de maio (FIGURA 26), tanto que cerca de $46 \%$ das amostras foram classificadas como inaceitáveis, pela baixa concentração de flúor (TABELA 39 e FIGURA 27). Esta classificação não mostrou correlação com a verificada nas amostras coletadas diretamente na ETA e poços, no mesmo período, quando $27 \%$ das amostras foram classificadas como inaceitáveis (TABELA 28). As concentrações de flúor verificadas nas amostras de água do setor I, abastecido pela ETA, mostraram correlação com aquelas verificadas nas amostras coletadas na Estação de Tratamento de Água (TABELA 38, FIGURA 26).

No mês de novembro, o setor $\mathrm{XI}$, abastecido pelo poço Lotes Urbanizados, voltou a apresentar baixas concentrações de flúor, com as médias oscilando entre 0,43 e 0,78 mg F/L, mas com predomínio de valores baixos (TABELA 40, FIGURA 28). Dois pontos de coleta deram mostras de interrupção da fluoretação, o ponto de número 8 do setor II e 014 do setor IV, ambos com média 0,13 mg F/L (FIGURA 28). Por sua vez, este foi o mês que apresentou as melhores concentrações, dentro dos níveis idealmente preconizados, com cerca de $52 \%$ das amostras classificadas em supra- 
ótima, e ainda $9 \%$ sub-ótima e $24 \%$ ótima, ou seja, $85 \%$ das amostras estavam dentro dos limites mínimo e máximo aceitáveis (FIGURA 29). Estes resultados demonstram que o sistema é capaz de fluoretar adequadamente a água de abastecimento público de Bauru, uma vez que cerca de $85 \%$ das amostras estavam dentro dos limites considerados aceitáveis (TABELA 41 e FIGURA 29). Os valores desejados deveriam variar desta porcentagem para acima, até alcançar 100\%. Esta meta de controle é totalmente possível, uma vez que uma cidade das dimensões de São Paulo conseguiu fazê-lo (ARMONIA et al. ${ }^{4}, 1995 ;$ NARVAI $\left.{ }^{98} ; 2001\right)$.

No mês de fevereiro de 2004 não foi mantido o padrão de fluoretação alcançado em novembro de 2003. Houve novamente uma tendência generalizada de subfluoretação, semelhante à evidenciada no mês de agosto. O setor XI voltou a dar mostras de baixa concentração de flúor em suas amostras, com as médias variando entre 0,49 e 0,59 mg F/L, o mesmo acontecendo com o setor I, onde a variação esteve entre 0,46 e 0,51 mg F/L (TABELA 42, FIGURA 30). De acordo com a classificação das amostras as concentrações inaceitáveis também foram constadas praticamente em todos os setores tanto que os resultados da classificação das amostras reforçam a percepção da situação, sendo que $51 \%$ das amostras foram classificadas como inaceitáveis (TABELA 43, FIGURA 31). Este foi o pior resultado verificado durante toda a pesquisa e não foi coincidente com o verificado nas amostras da ETA e dos poços o que pode ser explicado por algumas hipóteses. O sistema, através da sua malha de ligações no subsolo, acaba favorecendo a mistura da água de vários setores; as coletas se deram em momentos diferentes do dia ou ainda, a 
água que estava chegando nas residências poderia estar vindo do reservatório, e não diretamente do poço. Não é descartada a possibilidade de associação das três hipóteses. Mas, independente da justificativa, este fato demonstra uma grande flutuação nos teores de flúor da água de abastecimento público de Bauru. O mais preocupante é que o DAE, sabendo das datas em que se daria a coleta das amostras, presumidamente deveria estar colocando todos os seus esforços no sentido de manter as concentrações dentro do recomendado, objetivo este não alcançado.

Segundo a classificação das 697 amostras coletadas nos diferentes setores de abastecimentos na cidade de Bauru, no período de maio de 2003 à fevereiro de 2004, verifica-se que 34\% das amostras foram consideradas como inaceitáveis, por apresentarem uma concentração de flúor inferior a 0,55 mg/L, 62\% como aceitáveis, com a concentração de flúor variando entre 0,55 mg/L (teor mínimo) e 0,84 mg/L (teor máximo), sendo que $4 \%$ das amostras foram classificadas como inadequadas (teor variando entre 0,85 e 1,15 mg/L) (TABELA 45 e FIGURA 32).

A manutenção da fluoretação da água de abastecimento público é fundamental para que o controle parcial da cárie, alcançado em alguns países que empregam este método, perpetue (HOROWITZ ${ }^{74}, 1990$; SILVA $^{124}$, 1997; MODESTO et al. ${ }^{92}$, 1999; CURY $^{50}, 2001 ;$ NARVAI $^{98}, 2001$; BUZALAF $^{34}$ et al., 2002; WHITFORD ${ }^{149}$ et al., 2002). Pesquisas recentes sugerem que pode-se esperar que os níveis de cárie em crianças aumentem em áreas onde a fluoretação da água for interrompida ou encerrada, e nenhum outro método for oferecido (BRUNELLE; CARLOS ${ }^{26}, 1990$ ). Estas considerações podem ser confirmadas quando se analisa o levantamento 
Nacional de Saúde Bucal em escolares dos EUA, realizado em 1986/1987, onde as crianças que sempre viveram em cidade com água de abastecimento público fluoretada apresentaram um índice CPO-D 18\% menor que aquelas que sempre viveram em áreas não fluoretadas (BRUNELLE; CARLOS $\left.{ }^{26}, 1990\right)$. Embora a diferença média dos índices CPO-D entre as cidades fluoretadas e não fluoretadas apresentasse valores importantes no final da década de 80 , a magnitude desta diferença parece estar diminuindo (SALES PERES ${ }^{118}, 2001$; SEPPÄ et al. ${ }^{122}$, 2002).

No entanto, vale salientar que, embora haja uma tendência em se afirmar que a ação da fluoretação na prevenção da cárie dentária está diminuindo, na verdade o que está acontecendo é um emprego disseminado do flúor. Em princípio, deve-se considerar que houve um aumento no uso de fontes alternativas de flúor, como suplementos, aplicações tópicas, dentifrícios, soluções para bochecho, vernizes e outros. Além deste, outro aspecto importante é o fato de que o benefício da fluoretação da água de abastecimento tem uma ação difusa (fenômeno da difusão), ou seja, os produtos e bebidas processados em áreas fluoretadas acabam beneficiando áreas não fluoretadas, onde são consumidos. Desta forma a relevância da água de abastecimento pode estar sendo subestimada, devendo assim, ser considerada a contribuição direta e indireta do método (RIPA ${ }^{116}, 1993$; BUZALAF ${ }^{32}$, 1996; CURY $\left.^{50}, 2001\right)$. Segundo HOROWITZ, a fluoretação da água de abastecimento público é tão efetiva como sempre foi, capaz de prevenir cárie dentária em populações com alto risco à cárie dentária e sem acesso a outras fontes de flúor (HOROWITZ $\left.{ }^{74}, 1996\right)$. 
Os efeitos preventivos sobre a cárie dentária, resultantes do uso do flúor são específicos de cada indivíduo e do tempo de exposição, de forma que não podem ser experimentados por pessoas não diretamente expostas ao flúor. Ao contrário de outros métodos de prevenção de doenças, que resultam na erradicação de algum agente etiológico, os benefícios do flúor não são transmissíveis para as gerações futuras. Entretanto, é possível que, se a cárie dentária permanecer com índices baixos ou que estes declinem ainda mais, talvez a necessidade de continuar com a variedade e extensão dos programas de prevenção atualmente adotados, seja questionada (BRUNELLE; CARLOS $\left.{ }^{26}, 1990\right)$.

Para países com a maior parte da população vivendo em cidades com reservatórios de água de abastecimento público, a fluoretação é o método mais lógico, tanto do ponto de vista do custo-benefício e da segurança, quanto do impacto total na prevenção da cárie dentária (VIEGAS ${ }^{140}, 1987 ;$ HOROWITZ $\left.{ }^{73}, 1990\right)$. A fluoretação é seguramente o método com melhor relação custo-benefício para garantir a exposição tópica dos dentes continuamente desde a erupção e maximizar a colaboração do indivíduo (BRUNELLE; CARLOS $\left.{ }^{26}, 1990\right)$.

A interrupção definitiva da fluoretação da água de abastecimento faz cessar os benefícios, a adição de quantidades insuficientes de flúor torna a medida inócua, enquanto que a adição de quantidades excessivas podem causar fluorose dentária (CHAVES et al. $^{42}$, 1953). O fato de ambas serem indesejáveis, todos os esforços devem ser feitos no sentido de evitá-las, sendo imprescindível que haja permanente controle da fluoretação (NARVAI $^{98}$, 2001). A monitoração constante dos equipamentos de 
fluoretação, bem como da manutenção da concentração de flúor dentro dos padrões recomendados, é um problema constante (HOROWITZ $\left.{ }^{74}, 1996\right)$. A montagem de sistemas de heterocontrole pode contribuir efetivamente para melhorar a qualidade da fluoretação (NARVAI $\left.{ }^{98}, 2001\right)$.

O controle da qualidade da água de abastecimento público fornecida pelos órgãos ou empresas responsáveis pela sua distribuição e fluoretação, realizado, sobretudo por instituições relacionadas à saúde, tem se revelado de difícil aceitação e implantação (NARVAI $\left.{ }^{98}, 2001\right)$.

A necessidade de desenvolver mecanismos de controle da fluoretação fez surgir o conceito do heterocontrole (NARVAI $\left.{ }^{98}, 2001\right)$.

\section{Para NARVAI:}

"heterocontrole é o princípio segundo o qual se um bem ou serviço qualquer implica risco ou representa fator de proteção para a saúde pública então além do controle do produtor sobre o processo de produção, distribuição e consumo deve haver controle por parte das instituições do Estado" (NARVAl $\left.{ }^{97}, 2000\right)$.

Em 1996, apenas 32 municípios do Estado de São Paulo realizavam a vigilância sanitária dos teores de flúor na água de abastecimento público, o que corresponde a $44 \%$ da população beneficiada pela fluoretação. Entretanto, esta alta cobertura populacional em detrimento do número baixo de municípios, se deve à capital do Estado, a cidade de São Paulo que representa cerca de $74 \%$ da população deste grupo $\left(\right.$ CALVO $\left.^{36}, 1996\right)$. A exclusão de São Paulo resulta em uma população de apenas $8,9 \%$ da que é abastecida por água fluoretada no Estado. Os 
sistemas de vigilância devem ser ampliados para manter a segurança e garantir o benefício máximo da medida $\left(\right.$ CALVO $\left.{ }^{36}, 1996\right)$.

Seria de grande valia a implantação de programas de educação, treinamento e incentivo dos funcionários dos sistemas de fluoretação, no sentido de que estes sejam conscientizados a respeito da importância do trabalho por eles executado para a saúde da população e dos benefícios resultantes do mesmo, bem como, das conseqüências de quando este trabalho é negligenciado.

Mediante as informações e resultados prévios obtidos pela presente pesquisa, em março de 2004 foi implantado o heterocontrole da fluoretação da água de abastecimento público, em Bauru, pela Disciplina de Bioquímica, da Faculdade de Odontologia de Bauru - USP, com os mesmos profissionais envolvidos na elaboração e coordenação do projeto de monitoramento da fluoretação, com coletas realizadas mensalmente em algumas Unidades de Saúde e Escolas Públicas, abrangendo todos os setores de abastecimento da cidade. 
7 Conclusão 


\section{CONCLUSÃO}

A concentração de flúor presente na água de abastecimento público de Bauru, antes da fluoretação, mostrou-se constante nas diferentes estações do ano, não sofrendo portanto, interferência da sazonalidade, diferente daquela verificada após a fluoretação, que apresentou importantes variações, indicando que o sistema de abastecimento de Bauru não mantém constantes os níveis de flúor na água. 
AnEXos 
ANEXo 1 
INFOTEC No 103/04 (1/5)

INTERESSADO: Sra. Irene Ramires

PERÍODO SOLICITADO: Chuva, temperaturas máximas e mínimas de março/2003 a março/2004

Bauru, 23 de Agosto de 2004

Em atendimento à vossa solicitação, seguem em anexo os dados da precipitação (chuva) diária acumulada do município de Bauru - SP, referente ao período de março/2003 a março/2004 e das temperaturas máximas e mínimas do mesmo do mesmo período, para cálculo da temperatura média diária. Os dados foram coletados na estação meteorológica do IPMet/UNESP, localizada no Campus Universitário de Bauru, cuja posição é dada pelas seguintes coordenadas : Latitude : $22^{\circ} 21^{\prime} 30^{\prime \prime} \mathrm{S}$ Longitude : 4901' 37' W Altitude : 620 metros.

Segundo Figueiredo e Sugahara (1997), a temperatura média do ar (à sombra) nos meses mais quentes é de $26^{\circ} \mathrm{C}$ e nos meses mais frios, $20^{\circ} \mathrm{C}$.

A média das temperaturas máximas nos meses mais quentes é de 30 a $31^{\circ} \mathrm{C}$ e nos meses mais frios, em torno de $25^{\circ} \mathrm{C}$ apesar de ocorrerem recordes nas temperaturas máximas (próximo de $40^{\circ} \mathrm{C}$ ) nos meses de setembro e outubro.

A média das temperaturas mínimas nos meses mais quentes está entre 17 e $18^{\circ} \mathrm{C}$ e nos meses mais frios, entre $11^{\mathrm{a}} 13^{\circ} \mathrm{C}$. Recordes entre um máximo próximo de $24^{\circ} \mathrm{C}$ e um mínimo em torno de $0^{\circ} \mathrm{C}$, foram observados nos meses mais quentes e frios respectivamente.

Atenciosamente,

Zildene Pedrosa de Oliveira Emídio Meteorologista - CREA 0601837840/SP 
INFOTEC 103/04 (Continuação 2/5)

Chuva acumulada de março/2003 a março/2004

Dados coletados na Estação Meteorológica do IPMet

\begin{tabular}{|c|c|c|c|c|c|c|c|c|c|c|c|c|c|}
\hline dias & mar/03 & abr/03 & mai/03 & jun/03 & jul/03 & ago/03 & set/03 & out/03 & nov/03 & dez/03 & jan/04 & fev/04 & mar/04 \\
\hline 1 & 0.0 & 0.0 & 0.0 & 0.0 & 0.0 & 0.0 & 0.0 & 0.0 & 0.3 & 29.0 & 3.5 & 0.0 & 0,0 \\
\hline 2 & 0.0 & 0.0 & 0.0 & 0.0 & 0.0 & 0.0 & 0.0 & 0.0 & 0.3 & 12.6 & 4.1 & 0.0 & 0,0 \\
\hline 3 & 0.0 & 0.0 & 13.0 & 0.0 & 0.0 & 0.0 & 0.0 & 0.0 & 0.8 & 9.0 & 0.0 & 2.0 & 2,8 \\
\hline 4 & 0.7 & 1.0 & 0.0 & 20.0 & 0.0 & 0.0 & 0.0 & 0.0 & 0.0 & 48.0 & 0.0 & 9.0 & 15,0 \\
\hline 5 & 0.0 & 55.8 & 8.0 & 10.0 & 0.0 & 0.0 & 0.0 & 0.0 & 0.0 & 0.8 & 0.0 & 7.0 & 0,0 \\
\hline 6 & 3.2 & 0.0 & 0.0 & 4.0 & 0.0 & 0.0 & 0.0 & 0.0 & 5.6 & 16.0 & 0.0 & 0.0 & 0,0 \\
\hline 7 & 1.0 & 55.0 & 0.0 & 22.0 & 0.0 & 17.5 & 0.0 & 0.1 & 0.1 & 2.3 & 29.0 & 35.0 & 9,0 \\
\hline 8 & 28.5 & 0.0 & 0.0 & 0.0 & 0.0 & 1.6 & 0.0 & 6.0 & 0.0 & 0.0 & 10.0 & 0.0 & 0,0 \\
\hline 9 & 0.5 & 0.0 & 0.0 & 0.0 & 0.0 & 9.0 & 3.5 & 0.2 & 0.0 & 25.0 & 9.5 & 0.0 & 0,0 \\
\hline 10 & 0.0 & 2.0 & 0.0 & 0.0 & 13,5 & 0.3 & 0.6 & 6.0 & 0.0 & 1.2 & 5.2 & 0.0 & 0,0 \\
\hline 11 & 10.0 & 1.0 & 0.0 & 0.0 & 0.0 & 0.0 & 5.2 & 15.0 & 0.0 & 0.0 & 0.0 & 0.0 & 0,0 \\
\hline 12 & 6.2 & 0.0 & 0.0 & 0.0 & 0.0 & 0.0 & 0.3 & 16.0 & 0.0 & 5.4 & 7.0 & 0.0 & 0,0 \\
\hline 13 & 0.0 & 0.0 & 0.0 & 0.0 & 0.0 & 0.0 & 0.0 & 0.0 & 18.0 & 0.0 & 0.0 & 0.2 & 0,0 \\
\hline 14 & 9.0 & 0.0 & 0.0 & 0.0 & 0.0 & 0.0 & 0.0 & 0.0 & 2.0 & 0.0 & 0.0 & 18.5 & 30,0 \\
\hline 15 & 0.0 & 0.0 & 0.0 & 0.0 & 0.0 & 0.6 & 0.0 & 0.0 & 0.0 & 0.0 & 0.0 & 30.0 & 9,8 \\
\hline 16 & 0.0 & 0.0 & 0.0 & 0.0 & 0.0 & 0.0 & 7.0 & 0.0 & 0.0 & 0.0 & 0.0 & 0.0 & 0,0 \\
\hline 17 & 0.0 & 0.0 & 0.0 & 0.0 & 0.0 & 0.0 & 0.0 & 0.0 & 19.5 & 0.0 & 0.0 & 0.0 & 0,0 \\
\hline 18 & 0.0 & 0.0 & 0.0 & 0.0 & 0.0 & 0.0 & 0.0 & 0.0 & 6.0 & 0.0 & 0.0 & 0.0 & 20,3 \\
\hline 19 & 0.0 & 3.4 & 0.0 & 0.0 & 0.0 & 0.0 & 0.0 & 0.0 & 6.0 & 0.0 & 0.0 & 0.0 & 0,0 \\
\hline 20 & 0.0 & 53.0 & 0.0 & 0.0 & 0.0 & 0.0 & 0.0 & 0.0 & 0.0 & 0.0 & 0.0 & 0.0 & 0,0 \\
\hline 21 & 19.5 & 0.7 & 0.0 & 0.0 & 0.0 & 0.0 & 0.0 & 0.6 & 0.0 & 0.0 & 0.0 & 12.5 & 1,0 \\
\hline 22 & 0.5 & 0.0 & 0.0 & 0.0 & 0.0 & 0.0 & 0.0 & 5.0 & 0.0 & 20.0 & 0.0 & 0.1 & 0,0 \\
\hline 23 & 0.0 & 1.7 & 0.0 & 0.0 & 0.0 & 0.0 & 0.0 & 0.0 & 0.0 & 42.0 & 0.0 & 8.0 & 0,0 \\
\hline 24 & 0.0 & 0.0 & 17.5 & 0.0 & 0.0 & 0.0 & 0.0 & 0.0 & 3.2 & 0.0 & 9.5 & 0.2 & 0,0 \\
\hline 25 & 0.0 & 0.0 & 0.0 & 0.0 & 0.0 & 3.8 & 0.0 & 0.0 & 1.9 & 0.0 & 22.5 & 33.0 & 0,0 \\
\hline 26 & 0.0 & 0.0 & 0.0 & 0.0 & 0.0 & 0.3 & 0.0 & 0.0 & 53.0 & 0.0 & 36.0 & 0.0 & 0,0 \\
\hline 27 & 16.0 & 0.0 & 0.0 & 0.0 & 0.0 & 0.0 & 0.0 & 24.5 & 17.5 & 0.0 & 56.0 & 0.0 & 0,0 \\
\hline 28 & 0.0 & 0.0 & 0.0 & 0.0 & 0.0 & 0.0 & 0.0 & 5.8 & 9.0 & 3.6 & 30.0 & 6.8 & 0,0 \\
\hline 29 & 0.0 & 0.0 & 0.0 & 0.0 & 0.0 & 0.0 & 0.0 & 16.0 & 0.5 & 0.0 & 14.0 & 0.0 & 0,0 \\
\hline 30 & 0.0 & 0.0 & 0.0 & 0.0 & 0.0 & 0.0 & 0.0 & 0.0 & 0.0 & 0.0 & 0.0 & & 0,0 \\
\hline 31 & 0.0 & & 0.0 & & 0.0 & 0.0 & & 0.0 & & 18.0 & 29.0 & & 0,0 \\
\hline acumu & 95.1 & 173.6 & 38.5 & 56.0 & 13,5 & 33.1 & 16.6 & 95.2 & 143.7 & 214.9 & 265.3 & 162.3 & 87.9 \\
\hline
\end{tabular}


INFOTEC 103/04 (Continuação 3/5)

\begin{tabular}{|c|c|c|c|c|c|c|c|c|}
\hline & $\mathrm{mar} / 03$ & & $\mathrm{abr} / 03$ & & mai/03 & & jun/03 & \\
\hline Dias & Min & Max & Min & Max & Min & Max & Min & $\operatorname{Max}$ \\
\hline 1 & 22.2 & 35.0 & 19.4 & 31.4 & 20.0 & 30.2 & 16.2 & 26.8 \\
\hline 2 & 21.8 & 33.2 & 17.0 & 32.2 & 20.0 & 24.4 & 14.6 & 27.6 \\
\hline 3 & 21.0 & 33.4 & 17.8 & 29.4 & 11.6 & 21.6 & 16.2 & 28.0 \\
\hline 4 & 19.6 & 31.4 & 18.6 & 22.8 & 12.0 & 23.6 & 16.4 & 25.2 \\
\hline 5 & 21.2 & 32.6 & 18.0 & 25.2 & 14.8 & 20.0 & 15.4 & 20.4 \\
\hline 6 & 20.6 & 32.8 & 19.4 & 25.2 & 15.4 & 23.8 & 16.6 & 27.6 \\
\hline 7 & 20.0 & 30.4 & 18.4 & 24.4 & 9.4 & 21.4 & 18.6 & 29.4 \\
\hline 8 & 19.8 & 27.0 & 14.6 & 26.8 & 7.6 & 22.8 & 17.6 & 26.0 \\
\hline 9 & 20.8 & 25.8 & 16.4 & 28.0 & 11.0 & 22.0 & 15.4 & 27.6 \\
\hline 10 & 20.6 & 25.2 & 20.4 & 25.0 & 11.6 & 22.6 & 16.0 & 27.6 \\
\hline 11 & 20.4 & 27.0 & 19.8 & 27.4 & 13.2 & 24.2 & 15.8 & 27.4 \\
\hline 12 & 21.6 & 28.8 & 11.2 & 26.4 & 13.6 & 25.2 & 17.0 & 27.0 \\
\hline 13 & 21.0 & 27.8 & 11.4 & 23.8 & 14.6 & 25.2 & 16.2 & 29.0 \\
\hline 14 & 19.8 & 31.0 & 14.0 & 26.6 & 15.0 & 25.4 & 17.2 & 28.2 \\
\hline 15 & 20.0 & 32.8 & 15.6 & 26.6 & 15.4 & 26.8 & 15.0 & 27.0 \\
\hline 16 & 20.4 & 30.4 & 16.6 & 28.2 & 16.0 & 27.6 & 15.6 & 27.6 \\
\hline 17 & 20.4 & 28.2 & 16.2 & 29.4 & 16.6 & 28.0 & 15.8 & 28.4 \\
\hline 18 & 18.0 & 26.8 & 17.0 & 29.4 & 15.8 & 26.2 & 16.4 & 27.8 \\
\hline 19 & 18.4 & 29.6 & 20.8 & 29.4 & 14.4 & 26.2 & 15.0 & 27.6 \\
\hline 20 & 19.0 & 31.4 & 18.2 & 23.8 & 14.8 & 27.4 & 15.4 & 26.2 \\
\hline 21 & 20.2 & 27.4 & 18.2 & 26.2 & 17.8 & 29.2 & 13.2 & 25.6 \\
\hline 22 & 18.0 & 27.4 & 19.2 & 29.6 & 17.8 & 29.4 & 14.0 & 27.2 \\
\hline 23 & 16.4 & 27.8 & 19.0 & 29.6 & 19.2 & 25.4 & 13.8 & 26.6 \\
\hline 24 & 17.8 & 27.8 & 18.2 & 29.6 & 13.8 & 21.8 & 15.0 & 28.0 \\
\hline 25 & 18.2 & 27.4 & 18.4 & 29.8 & 8.6 & 22.0 & 14.8 & 27.6 \\
\hline 26 & 18.8 & 22.8 & 18.8 & 31.2 & 10.0 & 23.6 & 13.2 & 27.6 \\
\hline 27 & 18.2 & 27.2 & 19.8 & 30.4 & 11.2 & 20.2 & 13.2 & 27.6 \\
\hline 28 & 16.8 & 27.0 & 20.0 & 30.4 & 10.6 & 25.2 & 14.6 & 28.2 \\
\hline 29 & 16.2 & 29.8 & 19.8 & 30.2 & 10.6 & 24.2 & 14.0 & 27.8 \\
\hline 30 & 17.4 & 31.0 & 20.0 & 31.8 & 13.8 & 26.0 & 10.8 & 22.4 \\
\hline \multirow[t]{3}{*}{31} & 19.0 & 31.2 & & & 15.0 & 27.8 & & \\
\hline & \multirow{2}{*}{$\begin{array}{r}\text { T_Mínima } \\
19.5\end{array}$} & láxima 7 & 'Inima & dxima & & Idxilla & VIInima & \\
\hline & & 29.3 & 17.7 & 27.9 & 13.9 & 24.8 & 15.3 & 27.0 \\
\hline
\end{tabular}


INFOTEC 103/04 (Continuação 4/5)

\begin{tabular}{|c|c|c|c|c|c|c|c|c|c|}
\hline $\mathrm{jul} / 03$ & & $\mathrm{ago} / 03$ & & set/03 & & out/03 & & nov/03 & \\
\hline Min & Max & Min & Max & Min & Max & Min & Max & Min & Max \\
\hline 11.8 & 25.6 & 14.0 & 27.2 & 11.4 & 29.0 & 14.8 & 32.8 & 19.8 & \\
\hline 14.8 & 26.4 & 14.8 & 27.8 & 12.2 & 28.4 & 15.4 & 34.0 & 16.6 & \\
\hline 11.6 & 25.2 & 13.8 & 28.8 & 11.6 & 27.2 & 16.8 & 35.0 & 14.0 & \\
\hline 11.8 & 26.2 & 13.8 & 28.4 & 13.4 & 29.4 & 17.4 & 35.0 & 11.4 & \\
\hline 13.4 & 27.4 & 16.4 & 30.4 & 14.6 & 31.6 & 17.6 & 36.2 & 14.0 & \\
\hline 14.0 & 27.2 & 19.6 & 23.6 & 15.4 & 30.2 & 20.4 & 29.8 & 15.4 & \\
\hline 16.0 & 27.0 & 16.2 & 20.4 & 16.4 & 31.2 & 21.0 & 23.8 & 16.6 & \\
\hline 14.0 & 29.0 & 14.6 & 24.6 & 18.8 & 26.8 & 17.6 & 28.6 & 15.0 & \\
\hline 15.0 & 29.0 & 16.4 & 20.6 & 17.6 & 24.0 & 18.8 & 30.8 & 17.4 & \\
\hline 16.6 & 20.6 & 10.0 & 18.8 & 18.2 & 20.0 & 16.8 & 26.4 & 20.0 & \\
\hline 13.6 & 20.6 & 6.2 & 20.6 & 12.0 & 20.4 & 15.8 & 19.6 & 20.0 & \\
\hline 8.0 & 19.2 & 8.6 & 24.0 & 8.8 & 27.4 & 12.6 & 24.6 & 22.2 & 34.2 \\
\hline 9.4 & 20.6 & 10.4 & 27.2 & 14.8 & 24.0 & 13.8 & 26.6 & 20.0 & 34. \\
\hline 9.6 & 24.2 & 11.6 & 27.6 & 12.0 & 25.7 & 13.4 & 26.6 & 18.6 & \\
\hline 13.4 & 25.2 & 14.0 & 26.4 & 12.6 & 30.6 & 11.8 & 27.8 & 16.8 & 30.8 \\
\hline 13.6 & 26.8 & 14.2 & 24.2 & 15.6 & 22.4 & 11.8 & 28.8 & 19.8 & 31.2 \\
\hline 14.0 & 24.8 & 7.3 & 21.8 & 13.4 & 25.2 & 11.0 & 32.4 & 19.6 & 27.6 \\
\hline 13.4 & 26.2 & 7.8 & 23.8 & 12.2 & 29.4 & 16.0 & 34.2 & 20.8 & \\
\hline 14.2 & 28.2 & 9.4 & 28.8 & 14.0 & 32.6 & 20.0 & 35.4 & 17.6 & 24.8 \\
\hline 14.6 & 29.0 & 13.4 & 30.2 & 19.0 & 34.8 & 20.4 & 32.8 & 16.8 & \\
\hline 14.8 & 29.6 & 14.6 & 30.4 & 15.6 & 32.8 & 18.4 & 24.2 & 18.2 & 27.8 \\
\hline 16.2 & 29.0 & 14.6 & 31.6 & 16.0 & 34.6 & 16.4 & 26.6 & 17.4 & 30.6 \\
\hline 13.8 & 29.4 & 15.2 & 32.4 & 16.6 & 35.8 & 17.6 & 29.6 & 18.8 & 27.4 \\
\hline 15.6 & 27.6 & 16.6 & 34.2 & 20.2 & 36.6 & 16.0 & 33.2 & 18.2 & 27.2 \\
\hline 15.4 & 27.8 & 15.4 & 24.0 & 18.2 & 33.0 & 17.8 & 33.6 & 19.4 & 31.6 \\
\hline 18.0 & 25.4 & 10.6 & 21.8 & 18.2 & 24.8 & 21.4 & 32.2 & 20.8 & 27.8 \\
\hline 14.2 & 24.6 & 9.0 & 23.6 & 15.8 & 28.2 & 18.8 & 34.4 & 17.5 & 29.2 \\
\hline 14.6 & 25.0 & 11.6 & 22.8 & 16.8 & 32.6 & 17.8 & 23.6 & 18.8 & 26.6 \\
\hline 14.0 & 27.4 & 10.2 & 21.6 & 18.2 & 31.6 & 16.4 & 26.2 & 17.4 & 29.4 \\
\hline 17.2 & 29.2 & 10.2 & 26.4 & 14.8 & 31.4 & 17.2 & 30.4 & 17.2 & 33.6 \\
\hline 15.6 & 27.8 & 11.6 & 25.8 & & & 17.4 & 32.0 & & \\
\hline
\end{tabular}

\section{$\begin{array}{llllllllll}13.9 & 26.2 & 12.6 & 25.8 & 15.1 & 29.1 & 16.7 & 29.9 & 17.9 & 29.5\end{array}$}


INFOTEC 103/04 (Continuação 5/5)

\begin{tabular}{|c|c|c|c|c|c|c|c|}
\hline dez/03 & & $\mathrm{jan} / 03$ & & fev/03 & & mar/03 & \\
\hline Min & Max & Min & Max & Min & Max & Min & Max \\
\hline 19.4 & 28.8 & 20.6 & 24.8 & 21.0 & 30.6 & 18.6 & 30.0 \\
\hline 20.8 & 32.2 & 17.4 & 24.0 & 20.2 & 30.0 & 18.8 & 32.1 \\
\hline 21.2 & 30.8 & 15.6 & 26.4 & 20.6 & 29.8 & 22.2 & 30.8 \\
\hline 19.8 & 28.6 & 17.6 & 29.4 & 20.8 & 31.6 & 18.8 & 26.8 \\
\hline 21.6 & 29.0 & 17.8 & 30.6 & 22.0 & 31.2 & 19.2 & 27.7 \\
\hline 19.8 & 30.2 & 18.8 & 28.4 & 22.4 & 27.8 & 18.0 & 27.4 \\
\hline 18.8 & 27.8 & 19.8 & 27.8 & 18.8 & 27.2 & 18.6 & 29.2 \\
\hline 19.8 & 30.0 & 20.0 & 26.8 & 16.4 & 27.2 & 19.6 & 30.6 \\
\hline 18.8 & 24.6 & 20.8 & 30.6 & 16.6 & 27.2 & 20.8 & 31.2 \\
\hline 17.0 & 27.4 & 19.6 & 30.0 & 16.4 & 28.4 & 21.4 & 33.0 \\
\hline 21.2 & 33.6 & 19.8 & 33.6 & 18.2 & 29.4 & 20.6 & 30.8 \\
\hline 18.8 & 27.8 & 21.2 & 34.0 & 17.2 & 30.2 & 19.8 & 24.4 \\
\hline 19.1 & 31.6 & 18.6 & 32.6 & 18.4 & 30.4 & 18.8 & 30.2 \\
\hline 20.0 & 33.6 & 19.6 & 33.0 & 17.2 & 22.6 & 20.0 & 22.8 \\
\hline 21.2 & 34.2 & 21.6 & 32.6 & 20.4 & 30.4 & 18.8 & 30.6 \\
\hline 22.6 & 35.6 & 19.2 & 31.0 & 19.0 & 32.0 & 18.8 & 31.4 \\
\hline 20.2 & 28.0 & 17.6 & 30.2 & 18.6 & 33.2 & 18.6 & 29.4 \\
\hline 18.0 & 29.8 & 16.6 & 30.2 & 20.0 & 31.6 & 17.4 & 30.0 \\
\hline 18.6 & 32.0 & 16.8 & 30.4 & 21.8 & 32.2 & 18.8 & 27.8 \\
\hline 19.8 & 32.2 & 19.4 & 28.2 & 19.6 & 31.4 & 17.8 & 29.4 \\
\hline 20.4 & 33.8 & 20.4 & 27.6 & 19.0 & 31.2 & 16.4 & 27.2 \\
\hline 19.8 & 31.8 & 19.6 & 28.8 & 21.0 & 27.4 & 15.0 & 26.2 \\
\hline 19.4 & 31.0 & 19.8 & 29.6 & 18.0 & 25.4 & 14.6 & 26.2 \\
\hline 18.0 & 27.2 & 20.0 & 27.4 & 18.2 & 22.6 & 14.2 & 27.6 \\
\hline 16.8 & 29.0 & 20.4 & 23.2 & 18.0 & 24.4 & 14.6 & 28.2 \\
\hline 17.8 & 29.9 & 20.0 & 23.2 & 16.8 & 31.2 & 15.6 & 29.2 \\
\hline 18.6 & 31.4 & 17.6 & 25.0 & 17.8 & 31.4 & 15.6 & 30.2 \\
\hline 19.2 & 30.0 & 20.6 & 27.4 & 16.0 & 30.8 & 16.8 & 30.2 \\
\hline 20.0 & 29.2 & 20.0 & 29.2 & 18.4 & 32.0 & 16.8 & 32.0 \\
\hline 20.6 & 29.6 & 21.2 & 30.6 & & & 16.8 & 32.2 \\
\hline 21.2 & 29.0 & 19.6 & 29.6 & & & 16.8 & 30.4 \\
\hline
\end{tabular}

T

Mínima T_Máxima T_Mínima T_Máxima T_Mínima T_Máxima T_Mínima T_Máxima

$\begin{array}{llllllll}19.6 & 30.3 & 19.3 & 28.9 & 18.9 & 29.3 & 18.0 & 29.2\end{array}$


ANEXo 2 
Anexo 3 
ANEXO 4 


\section{a Saúde da Gestante e do seu}

BEBÊ

ATENÇÃo, MAMÃe!

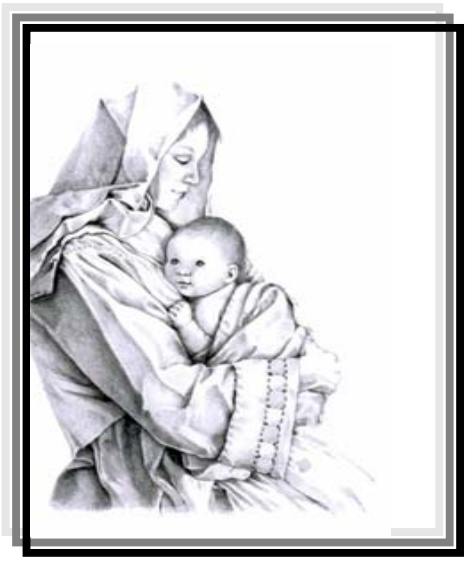

Você sabia que a cárie é uma doença transmissível, ou seja, que pode ser passada de uma pessoa para outra? Isso acontece quando há troca de saliva entre pessoas, onde microrganismos podem estar presentes. A cárie é uma doença e para que ocorra depende não só do microrganismo (bichinho da cárie), mas da alimentação e das condições de higiene bucal de cada um.

Por isso, mamãe, não prove os alimentos do seu filho com a mesma colher que vai alimentá-lo, nem mesmo experimente o leite no bico da mamadeira. Você pode estar expondo seu filho ao risco de ter cárie.

A alimentação da mamãe é importante para a saúde geral e dos dentes do futuro bebê? Sim, por isso deve seguir as orientações passadas pelo médico que a acompanha, fazendo regularmente os exames e tomando as vitaminas por ele indicadas, que na verdade não engordam. Devem ser evitados alimentos doces, assim como refrigerantes, que não fazem bem à saúde e ainda aumentam o risco de cárie.

Você acredita que a gravidez afeta a saúde dos dentes da futura mamãe? Isso não é verdade. Algumas mães têm apresentado problemas de saúde bucal durante a gestação, mas são decorrentes de problemas já existentes anteriormente, que se agravaram, ou ainda, conseqüência da falta de atenção e até mesmo de higiene bucal nesta fase de grandes mudanças.

É preciso cuidado com alterações nos hábitos alimentares. 
A gestante pode fazer tratamento dentário durante a gestação, sendo mais indicado a partir do terceiro mês. Atendimentos de emergência podem ser feitos antes. Para fazer radiografia, usar sempre proteção com avental de chumbo.

Quando o bebê nasce, ouvimos sempre dizer que é importante que a criança tome o sol da manhã; sabe por quê? O sol estimula a produção de vitamina D, no organismo, que participa da absorção do cálcio presente nos alimentos, fundamental na formação dos ossos e dos dentes da criança.

Mamãe, escove muito bem os seus dentes, para manter a sua saúde e a do seu bebê.
I mportante: 0 flúor presente nos cremes dentais tem ação local (direta no dente), o que auxilia, e muito, na prevenção da cárie. É um método que complementa a ação da fluoretação da água na prevenção da cárie. No entanto, é de fundamental importância saber que não se deve engolir creme dental, principalmente crianças entre 11 meses e 7 anos de idade. Dependendo da dosagem, pode causar problemas à saúde e não benefícios. O flúor que deve ser ingerido para prevenir a cárie dentária está presente na água adequadamente fluoretada, não no creme dental.
UNI VERSI DADE DE SÃO PAULO

FACULDADE DE ODONTOLOGI A DE BAURU

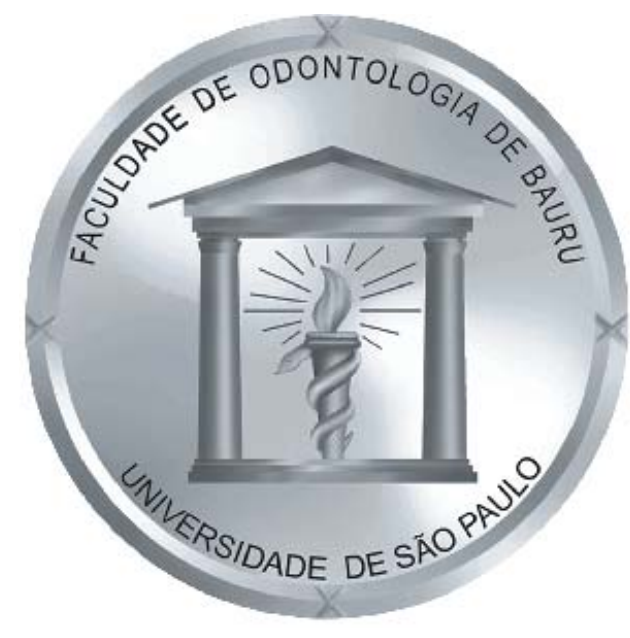

ÁREAS DE BI OQUÍ MI CA E DE SAÚDE COLETIVA

ORI ENTADORES:

Prof $^{\mathrm{a}} \mathrm{Dr}^{\mathrm{a}}$ Marília Afonso Rabelo Buzalaf

Prof. Dr. J osé Roberto Pereira Lauris

PESQUI SADORA:

Irene Ramires 
Anexo 5 
ANEXO 6 
Anexo 7 


\section{FATORES DE RISCO}

- Fumar qualquer tipo de cigarro;

- Fazer uso de qualquer tipo de tabaco;

- Ingerir bebidas alcoólicas com freqüência, principalmente quando associadas ao cigarro;

- Ter mais de 40 anos;

- Trabalhar exposto ao sol;

- Hábitos com estímulos traumáticos constantes na mesma área;

- Ter casos de câncer na família (em qualquer região do corpo);

- Ocorrência de câncer em outras regiões do corpo.

\section{ATENCÃO}

O CÂNCER DE BOCA NÃO DÓI EM SEU ESTÁGI O I NI CI AL.

PROCURE UM CIRURGI ÃO-DENTI STA SE ENCONTRAR QUALQUER ALTERAÇÃO QUE PERSI STA POR MAIS DE 15 DI AS.

\section{PREVINA-SE!}

O TRATAMENTO E AS POSSIBILIDADES DE CURA DO CÂNCER DE BOCA SÃO MAIS FAVORÁVEIS QUANDO ESTE É DIAGNOSTICADO EM SUA FASE INCIAL

\section{UNI VERSI DADE DE SÃO PAULO}

Faculdade de Odontologia de Bauru

Departamento de Odontopediatria, Ortodontia e Saúde Coletiva

Área de Saúde Coletiva

\section{PREVENÇÃO DE CÂNCER DE BOCA}

\section{Auto-Exame}

Orientadores: Profa. Dra. Marília Afonso Rabelo Buzalaf Prof. Dr. José Roberto Pereira Lauris

Profa. Silvia Helena de C. Sales Peres

Mestrandos: Fabiano Vieira Vilhena

Irene Ramires

Lucilene Sanchez Cirilo da Cunha

Roberta Francisca Martins de Castro 


\section{CÂNCER DE BOCA}

Segunda dados do Instituto Nacional do Câncer, em 1999, cerca de 8.00 novos casos de câncer bucal foram registrados no Brasil. Estes dados colocam a doença entre as 10 primeiras localizações primárias da lesão na população brasileira, sendo que há um maior número de casos de câncer de pele, mama e de colo de útero.

Para que se consiga mudar este quadro é preciso que haja uma ação conjunta dos profissionais de saúde na conscientização da população da importância do AUTO-EXAME na prevenção do câncer de boca.

AUTO-EXAME: COMO REALIZÁ-LO
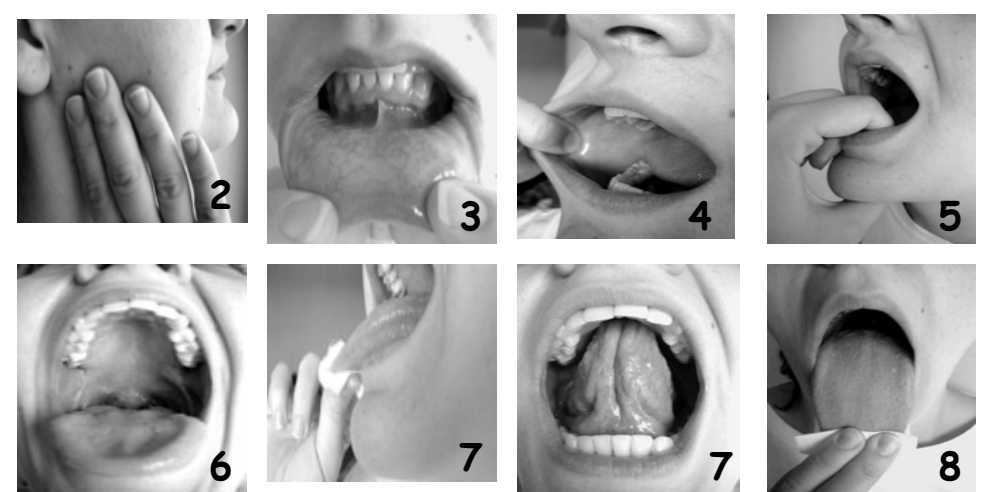

1. Lave bem as mãos e a boca e, caso use próteses removíveis (pontes), retire-as;

2. Em frente ao espelho, observe a pele da face e do pescoço e veja se há algo de diferente (como manchas, pintas ou alterações como nódulos e/ou inchaços);

3. Puxe o lábio inferior para baixo, observe sua parte interna (mucosa) e apalpe-o. Faça o mesmo com o lábio superior;

4. Com a ponta do dedo, percorra toda a gengiva inferior e superior, na parte da frente e de trás dos dentes. Faça o mesmo no palato ("céu da boca") e na bochecha;

5. Coloque o dedo indicador por baixo da língua e o polegar da mesma mão no queixo, apalpando o assoalho da boca;

6. Tente enxergar o palato inclinando sua cabeça para trás. Diga "AH" e tente observar o fundo da garganta;

7. Ponha a língua para fora e observe sua parte de cima. Com a língua no palato, observe sua parte de baixo. Para observar as laterais, puxe-a com o auxílio de uma toalha ou gaze para a esquerda e para a direita;

8. Ainda com o auxílio de uma toalha, apalpe a língua;

9. Repita o exame mensalmente e consulte 0 cirurgião-dentista 
REFERÊNCIAS BIBLIOGRÁFICAS 


\section{REFERÊNCIAS BIBLIOGRÁFICAS*}

1. AMARANTE, L.M.; JITOMIRSKI, F.; AMARANTE, C.L.F. Flúor: benefícios e controvérsias dos programas de fluoretação. Rev Bras Odontol, v.50, n.4, p.22-30, 1993.

2. ANGMAR-MANSSON, B.; WHITFORD, G.M. Environmental and physiological factors affecting dental fluorosis. J dent Res, v.69 (Special issue), p.706-13, 1990.

3. [ANVISA] Agência Nacional de Vigilância Sanitária. História da vigilância sanitária no Brasil. Disponível na Internet. http://www.anvisa.gov.br/inst/história.htm.

4. ARMONIA, P.L. et al. Estado atual da fluoretação das águas de abastecimento público no município de São Paulo. Rev Inst Cienc Saúde, v.13, n.2, p.63-6, 1995.

5. ASSIS, G.F. et al. Mecanismos biológicos e influência de fatores ambientais na fluorose dentária e a participação do flúor na prevenção da cárie. Revisão de literatura. Rev Fac Odontol Bauru, v.7, v.3/4, p.63-70, 1999.

6. BAELUM, V. et al. Daily dose of fluoride and dental fluorosis. Tandlaegebladet, v.91, p.452-6, 1987.

7. BARDSEN, A. "Risk periods" associated with the development of dental fluorosis on maxillary permanent central incisors. Acta Odontol Scand, v.57, n.5, p.247-56, 1999.

\footnotetext{
* Normas recomendadas para uso no âmbito da Universidade de São Paulo, com base no documento "Referências Bibliográficas: exemplos", emanado do Conselho Superior do Sistema Integrado de Bibliotecas da USP, em reunião de 20 de Setembro de 1990.
} 
8. BARROS, E.R.C.; TOVO, M.F.; SCAPINI, C. Análise Crítica da Fluoretação de Águas. Rev Gauch Odontol, v.38, n.4, p.247-54, 1990.

9. BARROS, E.R.C.; SCAPINI, C.; TOVO, M.F. Resultados da fluoretação da água. Rev Gauch Odontol, v.41, n.5, p.303-8, 1993.

10. BASting, R.T., PEREIRA, A.C., MENEGHIM, M.C. Avaliação da prevalência de cárie dentária em escolares do município de Piracicaba, SP, Brasil, após 25 de fluoretação das águas de abastecimento público. Rev Odontol Univ São Paulo, v.11, n. 4, p.287-92, 1997.

11. BASTOS, J.R.M., FREITAS, S.F.T. Declínio da cárie dentária em Bauru-SP, após 15 anos de fluoretação de água de abastecimento público. Odontologia Capixaba, v.19, n.20, p.9-12, 1991.

12. BASTOS, J.R.M.; LOPES, E.S.; FREITAS, S.F.T. Panorama mundial após 50 anos de uso do flúor. Rev Gauch Odontol, v. 41, n.5, p. 309-11, 1993.

13. BASTOS, J.R.M. et al. Concentração de flúor em água mineral engarrafada e de fontes naturais das cidades de Lindóia, Águas de Lindóia e Serra Negra, Brasil. Rev Fac Odontol Univ Passo Fundo, v.6, n.1, p.15-9, 2001.

14. BASTOS, J.R.M.; LOPES, E.S.; RAMIRES, I. Manual de Odontologia Social e Preventiva. Fluoretação da água de abastecimento público. 2. ed. Bauru, FOB/USP, p.6-29, 2001.

15. BLACK, G.V.; MCKAY, F.S. Mottled teeh - an endemic developmental imperfection of the teeth heretofore unknown in the literature of dentistry. Dent Cosmos. 1916, v.58, p.129-56 apud FEJESKOV, 
O.; EKSTRAND, J.; BURT, B.A. Fluoride in dentistry. 2. ed. Copenhagen, Munksgaard. 1996. Cap.15, p.275-90.

16. BOOTH, I.M.; MITROPOULOS, C.M.; WORTHINGTON, H.V. A comparison between the dental health of 3-year-old children living influoridated Huddersfiel and non fluoridated Dewsbury in 1989. Community Dent Hlth, v.9, p.151-7, 1991.

17. BRASIL. Ministério da Saúde. Lei Federal $n^{\circ} 6050$ de 24 de maio de 1974. Brasília, DF, D.O.U., 1974.

18. BRASIL. Ministério da Saúde. Decreto $n^{\circ} 76.872$ de 22 de dezembro de 1975. Regulamenta a lei $n^{\circ} 6050$ de 24 de maio de 1974. Brasília, DF, D.O.U., 1975.

19. BRASIL. Ministério da Saúde. Portaria nº 685/Bsb, de 25 de dezembro de 1975. Aprova as normas e padrões sobre a fluoretação da água dos sistemas públicos de abastecimento, destinada ao consumo humano. Brasília, DF, D.O.U., 1975.

20. BRASIL. Congresso Nacional. Lei Federal No 8.080, de 19/09/1990. Diário Oficial da União 20 de setembro de 1990, p.18055.

21. BRASIL. Ministério da Saúde. Tratamento e fluoretação da água dos municípios brasileiros [on line]. Disponível em URL: http://www.saude.gov.br/programas/bucal/fluoreta\%.htm. [2000 dez 18].

22. BRASIL. Ministério da Saúde. Situação da fluoretação da água de abastecimento público. Brasil 1996. Disponível na Internet. http://www.saude.gov.br/sps/aeastecnicas/bucal/inicial.htm. 
23. BRASIL. Ministério da Saúde. Programa de Saúde Bucal. Redução do índice CPO-D chega a quase 54\% em relação a 1989. CFO Informa, v.6, p.3, mar. 1997.

24. BRASIL. Ministério da Saúde. Comitê Técnico-Científico de Assessoramento à Área Técnica de Saúde Bucal. Brasília, 24 de agosto de 1999.

25. BRASIL. Ministério da Saúde. Portaria N518, de 25 de março de 2004. Estabelece os procedimentos e responsabilidade relativos ao controle e vigilância da qualidade da água para o consumo humano e seu padrão de potabilidade, e dá outra providências. Brasília, DF, D.O.U., 2004.

26. BRUNELLE, J.A.; CARLOS, J.P. Recent trends in dental caries in U.S. children and the effect of water fluoridatin. J dent Res, v.69 (Special issue), p.723-7, 1990.

27. BUENDIA, O.C. Fluoretação de águas: manual de orientação prática. São Paulo, American Med, 1996. 138p.

28. BUENDIA, O.C.; ZAINA, I. Será o flúor o vilão? Rev Paul Odontol. v.36, n.2, mar./abr.1997.

29. BURT, B.A. The changing patterns of systemic fluoride intake. J Dent Res, v.71, n.5, (Special issue), p.1228-37, 1992.

30. BURT, B.A.; FEJERSKOV, O. Water fluoridation. In: FEJESKOV, O.; EKSTRAND, J.; BURT, B.A. Fluoride in dentistry. 2. ed. Copenhagen, Munksgaard. 1996. Cap.15, p.275-90.

31. BURT, B.A.; KEELS, M.A.; HELLER, K.E. The effects of a break in water fluoridation on the development of dental caries and fluorosis. J Dent Res, v.79, n.2, p.761-9, 2000. 
32. BUZALAF, M.A.R. Bioquímica do flúor: manual didático. Bauru, FOB/USP, 1996. 119p.

33. BUZALAF, M.A.R.; CURY, J.A.; WHITFORD, G.M. Fluoride expousures and dental fluorosis: a literature review. Rev Fac Odontol Bauru, v.9, n.1/2, p.1-10, 2001.

34. BUZALAF, M.A.R. et al. Fluctuations in public water fluotide level in Bauru, Brazil. J Publ Hlth Den, v.62, n.3, p.173-6, 2002.

35. BUZALAF, M.A.R. Fatores de risco para fluorose dentária e biomarcadores de exposição ao flúor. Bauru, 2002. Dissertação (Livre-Docente) - Faculdade de Odontologia de Bauru, Universidade de São Paulo.

36. CALVO, M.C.M. Situação da fluoretação de água de abastecimento público no Estado de São Paulo - Brasil. São Paulo, 1996. Dissertação (Mestrado). Faculdade de Saúde Pública, Universidade de São Paulo.

37. CAMPOS, D.L. et al. Prevalência de fluorose dentária em escolares de Brasília - Distrito Federal. Rev Odontol Univ São Paulo, v.12, n.3, p.225-30, jul./set. 1998.

38. CAPELLA, L.F. et al. Ocorrência de fluorose dentária endêmica. Rev Gauch Odontol, v.37, n.5, p.371-5, 1989.

39. CHAN, J.T. et al. Fluctuations in tap water fluoride levels: a potential problem for practitioners. Texas Dent J, v.110, n.2, p.17-9, 1993.

40. [CDC] Centers for Disease Control and Prevention. Engineering and administrative recommendations for water fluoridation, 1995. Morbidity and Mortality Weekly Reports, v.44, n.RR-13, p.1-40, 1995. 
41. [CDC] Centers for Disease Control and Prevention. Achievements in public helth, 1900-1999: Fluoridation of drinking water to prevent dental caries. Morbidity and Mortality Weekly Reports, v.48, n.4, p.993-40, 1999.

42. CHAVES, M.M.; FRANKEL, J.M.; MELLO, C. Fluoretação de águas de abastecimento público para a prevenção parcial da cárie dentária. Rev Assoc Paul Cir Dent, v.7, n.2, p.27-33, 1953.

43. CHAVES, M.M. Odontologia social. 3. ed. Rio de janeiro: Artmed, 1986.

44. CLOVIS, J.; HARGREAVES, J.A. Fluoride intake from beverage comsumption. Community Dent Oral Epidemiol, v.16, p.11-5, 1988.

45. COMITÊ TÉCNICO CIENTÍfICO DE SAÚDE BUCAL. Parecer técnico. Fluoretação da água de consumo. Disponível na Internet. http://www.saúde.gov.br/sps/areastecnicas/bucal/inicial.htm.

46. CONFERÊNCIA MUNICIPAL DE SAÚDE DE BAURU - IV. Junho de 2003.

47. Convênio repassa verba para fluoretar as águas de 116 municípios de São Paulo. Jornal do CROSP, v.23, n.99, p.8-10, jun./ago. 2004.

48. CURY, J.A. Concentração de fluoreto em chás brasileiros e seu significado na prevenção de cárie. Rev Gauch Odont, v.29, n.2, p.136-8, 1981.

49. CURY, J.A. Fluoretação da água: benefícios, riscos e sugestões. ROBRAC, v.2, n.5, p.32-33, 1992. 
50. CURY, J.A. Uso do flúor e controle da cárie como doença. In: BARATIERI, L.N. et al. Odontologia restauradora. São Paulo, Ed. Santos, 2001. Cap. 2, p.34-68.

51. CUTRESS, T.W. et al. Fluoride content of the enamel and dentine of human premolares prior $\mathrm{t}$ and following the introduction of fluoridation in New Zeland. Caries Res, v.30, n. 3, p.204-12, 1996.

52. DE PRETO, P.W. et al. Redução de cárie dentária emescolares de Bauru, após oito anos de fluoretação de água de abastecimento público. Estomat Cult, v.15, n.3, p.20-5, 1985.

53. DO CARMO, M.D. et al. Localidades com diferentes concentrações de flúor nas águas de consumo e a sua relação com a prevalência de fluorose dentária. Odontol Mod, v.22, n.4, p.18-21, 1995.

54. DUPERON, D.F.; JEDRYCHOWSKI, J.R.; KONG, J. Fluoride content of Los Angeles country water. CDA Journal, v.23, n.2, p.45-8, 1995.

55. EAGER, J.M. Chiaie teeth. Dent Cosmos. 1902. v.44, n.3, Abstract 151, p.300-1 apud PEREIRA, A.C. Odontologia em saúde coletiva. Planejando ações e promovendo saúde. Porto Alegre, Artmed, 2003. Cap.14, p.265-74.

56. EKANAYAKE, L.; HOEK, W. vander. Dental caries and clevelapmental defects of enamel in relation to fluoride levels in drinking water ina a aried areas of Sri Lanka. Caries Research, v.36, p.398-404, 2002.

57. EKSTRAND, J.; OLIVEBY, A. Fluoride in the oral environment. Acta Odontol Scand, v.57, p.325-9, 1999.

58. FEATHESTONE, J.D.B. et al. Dependenc of in vitro demineralization and remineralization of dental enamel on fluorid concentration. $\mathbf{J}$ Dent Res, v.69, p.620-5, 1990. 
59. FEATHERSTONE, J.D.B. Prevention and reversal of dental caries: Role of low level fluoride. Community den oral Epidemiol, v.27, n.31, p.31-40, 1999.

60. FEJERSKOV, O.; THYLSTRUP, A.; LARSEN, M.J. Rational use of fluorosis in caries prevention. Acta Odontol Scand, v.39, p.241-9, 1981.

61. FEJERSKOV, O.; THYLSTRUP, A. Fluorose dentária: um manual para profissionais da saúde. São Paulo, Ed. Santos, 1994, 122p.

62. FEJERSKOV, O.; BAELUM, V.; RICHARDS, A. Dose-response and dental fluorosis. In: FEJESKOV, O.; EKSTRAND, J.; BURT, B.A. Fluoride in dentistry. Copenhagen, Munksgaard. 2. ed. 1996. Cap.9, p.153-66.

63. FERREIRA, H.C.G. et al. Avaliação do teor de flúor na água de abastecimento público do município de Vitória-ES. Rev Assoc Paul Cir Dent, v.53, n.6, p.455-9, 1999.

64. FOMON, S.J.; EKSTRAND, J.; ZIEGLER, E.E. Fluoride intake and prevalence of dental fluorosis: trends in fluoride intake whit special attention toinfants. J Publ Hlth Dent, v.60; n.3, p.131-9, 2000.

65. FRAZÃO, P. Epidemiologia em saúde bucal. In: PEREIRA, A.C. Odontologia em saúde coletiva. Planejando ações e promovendo saúde. Porte Alegre, Artmed, 2003. Cap. 4, p.64-82.

66. FREIRE, P.S.; FREIRE, A.S. Resultados de 7 anos de fluoretação de águas no Brasil. Rev Bras Odont, v.21, p.31-41, 1962.

67. FREIRE, A.S. Saúde oral do escolar do Espírito Santo - Panorama atual e perspectivas para o futuro. Odontol Capixaba, v.6, n.6, p.31-7, 1974. 
68. FREIRE, M. do C.M. et al. Prevalência de cárie e necessidade de tratamento em escolares de seis a doze anos de idade, Goiânia, GO, Brasil, 1994. Rev Saúde Pública, v.31, n.1, p.44-52, fev. 1997.

69. FREITAS, V. P. S. et al. Fluoreto em água: estudo de metodologia analítica e níveis encontrados na região de Campinas. Rev. Inst. Adolfo Lutz, v.56, n.2, p.29-36, 1996.

70. FUKUSHIMA, R. et al. Cinética do flúor na saliva de adultos e crianças após o uso de dentifrícios fluoretados. Rev Fac Odontol Bauru, v. 8, n. $1 / 2$, p. $45-50,2000$.

71. GALAGAN, D.J.; VERMILLION, J.R. Determining optimum fluoride concentrations. Publ HIth Rep, v.72, p.491-3, 1957.

72. GUHA-CHOWDHURY, N.; DRUMMOND, B.K.; SMILLIE, A.C. Total fluoride intake in children aged 3 to 4 years: a longitudinal study. J Dent Res, v.75, n.7, p.1452-7, 1996.

73. HOROWITZ, H.S. The future od the water fluoridation and other systemic fluorides. J Dent Res, v. 69 (Special issue), p.760-4, 1990.

74. HOROWITZ, H.S. The effectiveness of community water fluoridation in the Unidet States. J Publ HIth Dent, v.56 (Special issue), n.5, p.253-8, 1996.

75. ISMAIL, A.I. et al. Should the drinking water of Truro, Nova Scotia, be fluoridated? Water fluoridation in the 1990s. Commnity Dent. Oral Epiderm., v.21, n.3, p.118-25, 1993.

76. JACKSON, R.D. et al. Dental fluorosis in children residing in communities with different water fluoride levels: 33-month follow-up. Pediat Dent., v.21, n.4, p.248-54, 1999. 
77. KOZLOWSKI, F.C.; PEREIRA, A.C. Métodos de utilização de flúor sistêmico. In: PEREIRA, A.C. Odontologia em saúde coletiva. Planejando ações e promovendo saúde. Porto Alegre, Artmed, 2003. Cap.14, p.265-74.

78. KUHNS, C. Dt Mschr Zahnheilk. 1888, v.6, p.446 apud PEREIRA, A.C. Odontologia em Saúde Coletiva. Planejando ações e promovendo saúde. Porto Alegre, Artmed, 2003. Cap.14, p.26574.

79. Levantamento Epidemiológico de saúde bucal - Estado de São Paulo, 1998. São Paulo: UNIVERSIDADE DE SÃO PAULO, Faculdade de Saúde Pública e Pesquisas de Sistemas de Saúde, 1999.

80. LEVY, S.M.; KIRITSY, M.C., WARREN, J.J. Sources of fluoride intake in children. J Publ HIth Dent, v.55, n.1, p.39-52, Winter 1995.

81. LEVY, S.M.; GUHA-CHOWDHURT, N. Total fluoride intake and implications for dietary fluoride supplementation. J Publ HIth Dent., v.59 (Special issue), n.4, p.211-23, 1999.

82. LEWIS, D.W.; BANTING, D.W. Water fluoridation: current effectiveness and dental fluorosis. Community Dent Oral Epidemiol, v.22, n.3, p.153-8, 1994.

83. LIMA, Y.B.O; CURY, J.A. Ingestão de flúor por crianças pela água e dentifrício. Rev Saúde Pública, v.35, n.6, p.576-81, 2001.

84. LIMEBACK, H. A re-examination of the pre-eruptive and post-eruptive mechanism of the anti-caries effects of fluoride: Is there any anticaries benefit from swallowing fluoride? Community Dent Oral Epidem, v.27, p.62-71, 1999. 
85. LODI, C.S.; RAMIRES, I,; BASTOS, J.R.M. Concentração de flúor na água dos bairros abastecidos pela Estação de Tratamento de Água (ETA) de Bauru, SP. In: SIMPÓSIO DE INICIAÇÃO CIENTÍFICA DA USP, 11., Ribeirão Preto, 2003. Resumo dos Trabalhos. São Paulo, USP, 2003. Resumo Ficha 1521. Disponível na Internet. File://D:Ificha1521.htm.

86. MALTZ, M.; FARIAS, C. Fluorose dentária em escolares de quatro cidades brasileiras com e sem água artificialmente fluoretada. Rev Fac Odontol Porto Alegre, v.39, n.2, p.18-21, 1998.

87. MALTZ, M. et al. Prevalência de fluorose em duas cidades brasileiras, uma com água artificialmente fluoretada e outra com baixo teor de flúor, em 1987 e 1997/98. Rev Fac Odontol Porto Alegre, v.42, n.2, p.51-55, 2000.

88. MARTHALLER, T.M. Water fluoridation results in Basel since 1962: health and political implications. J Publ HIth Dent, v.56 (Special issue), n.5, p.265-70, 1996.

89. MCKAY, F.S., BLACK, G.V. An investigation of mottled teeth. Dent Cosmos. 1916. v,58, p.472-84. In: PEREIRA, A.C. Odontologia em saúde coletiva. Planejando ações e promovendo saúde. Porto Alegre, Artmed, 2003. Cap.14, p.265-74.

90. MCKAY, F.S.The relation of mottled enamel to caries. J Am Dent Assoc, v.15, p.1429-37, 1928 apud FEJERSKOV, O.; EKSTRAND, J.; BURT, B.A. Water Fluoridation. Copenhagen, Munkagaard. 2. ed. 1996. Cap.15. p.275-90.

91. MESSER , H.H.; OPHAUG, RH. Influence of gastric acidity on fluoride absortion in rats. J Dent Res, v.72, n.3, p.619-22, 1993. 
92. MODESTO, A. et al. Avaliação da concentração de fluoreto na água de abastecimento público do Rio de Janeiro. Rev Bras Odontol, v.56, n.5, p.217-21, set./out. 1999.

93. MURRAY, J.J. O uso correto de fluoretos na saúde pública. São Paulo, OMS/Ed. Santos, 1992. 131p.

94. NAGEM FILHO, $\mathrm{H}$. et al. Determinação da taxa de flúor da água de abastecimento da cidade de Bauru. Bauru, EDUSC, 1997.

95. NARVAI, P.C., CASTELLANOS, R.A. Levantamento epidemiólogico de saúde bucal: Estado de São Paulo, 1998. Jornal do COSEMS-SP, v.1, n.7, p.4, 1999.

96. NARVAI, P.C., FRAZÃO, P.; CASTELLANOS, R.A. Declínio na experiência de cárie em dentes permanentes de escolares brasileiros no final do século XX. Odontologia e Sociedade, v.1, n.1/2, p.25-9, 1999.

97. NARVAI, P.C., CASTELLANOS, R.A., FRAZÃO,P. Prevalência de cárie em dentes permanentes de escolares do Município de São Paulo, SP. Rev Saúde Pública, v.34, n.2, p.196-200, 2000.

98. NARVAI, P.C. Vigilância Sanitária da fluoretação das águas de abastecimento público no município de São Paulo, Brasil, no período de 1990-1999. São Paulo, 2001. Dissertação (LivreDocente) - Faculdade de Saúde Pública, Universidade de São Paulo.

99. NARVAI, P.C. Vigilância sanitária e saúde bucal. São Paulo: FSPUSP; 2002. 
100. NOBRE DOS SANTOS, M.; CURY, J.A. Dental plaque fluoride is lower after dicontinuation of water fluoridation. Caries Res, v.22, n.5, p.316-7, 1988.

101. OGAARD, B. et al. Microradiographic study of demineralization of shark enamel in human caries model. Scand J Dent Res, v.96, p.209-11, 1988.

102. OGAARD, B. et al. Effect of fluoride mouthrinsing on caries lesion development in shark enamel; an in situ caries model study. Scand J Dent Res, v.99, p.372-7, 1991.

103. OLIVEIRA, C.M.B.; ASSIS, D.F.; FERREIRA, E.F. Avaliação da fluoretação da água de abastecimento público de Belo Horizonte, MG, após 18 anos. Rev CROMOG, v.1, n.2, p.62-6, 1995.

104. O'MULLANE, D. et al. The results of water fluoridation in Ireland. J Publ HIth Dent, v.56 (Special issue), n. 5, p. 259-64, 1996.

105. [OMS] ORGANIZACIÓN MUNDIAL DE LA SALUD. Fluoruros y salud. Genebra, OMS; 1972. [Série de Monografias, n059].

106. [OMS] ORGANIZAÇÃO MUNDIAL DA SAÚDE. Dental caries levels at 12 years, may 1994. The Oral Health Programme. Genebra, 1994. $19 p$.

107. PANG, D.T.Y.; PHILLIPS, C.L.; BAWDEN, J.W. Fluoride intake from beverage consumption in a sample of North Carolina children. $\mathbf{J}$ Dent Res, v.71, n.7, p.1382-8, 1992.

108. PEREIRA, A.C. et al. Prevalência de cárie e fluorose dentária em escolares de cidades com diferentes concentrações de flúor na água de abastecimento. Rev Bras Odont Saúde Coletiva, v.2, n.1, p.34-9, 2001. 
109. PESSAN, J.P.; SILVA, S.M.B. da; BUZALAF M.A.R. Evaluation of the total fluoride intake of 4-7-year-old children from diet and dentifrice. J Appl Oral Sci, v.11, n.2, p.150-6, 2003.

110. PINTO, V.G. Revisão sobre o uso e segurança do flúor. RGO, v.41, n.5. p.263-6, 1993.

111. POLETTO, L.T. DE A. Levantamento epidemiológico do estado de saúde bucal da população urbana da cidade de Bauru. Bauru, 1993. 248p. Tese (Doutorado) - Faculdade de Odontologia de Bauru, Universidade de São Paulo.

112. RAMIRES, I. et al. Crianças livres de cárie, entre 7 e 12 anos de idade, Bauru, 2001. In: REUNIÃO ANUAL DA SBPqO, 2002. Anais São Paulo, SBPqO, 2002. v.16, p.24./Resumo PO08/

113. RAMIRES, I. et al. Avaliação da concentração de flúor e de consumo de água mineral. Rev Saúde Pública, v. 38, n.3, p.459-65, 2004.

114. Rede de Água de Bauru é Obsoleta. JORNAL DA CIDADE. 11 de julho de 2004, p.3.

115. REEVES, T.G. Status and strategic plans for fluoridation: Centers for Disease Control and Prevention perspective. J Publ Hlth Dent, v.56 (Special issue), n.5, p.242-5, 1996.

116. RIPA, L.W. A half-century of community water fluoridation in the United States: review and commentary. J Publ Hlth Dent, v.53, n.1, p.17-44, 1993.

117. SAMPAIO, F.C. et al. Dental caries and sugar intake of children from rural areas with different water fluoride levels in Paraíba, Brazil. Community Dent Oral Epidemiol, v.28, n.4, p.307-13, 2000. 
118. SALES PERES, S.H. de C. Perfil epidemiológico de cárie dentária, em cidades fluoretadas e não fluoretadas, na região CentroOeste do Estado de São Paulo. 2001, 178p. Dissertação (Mestrado) - Faculdade de Odontologia de Bauru, Universidade de São Paulo.

119. SALES PERES, S.H.C.S. et al. Avaliação da redução percentual de cárie dentária em escolares aos 12 anos de idade, entre 1976 e 2001, em Bauru-SP. In: REUNIÃO ANUAL DA SBPqO, 19., 2002. Anais São Paulo, SBPqO, 2002. v.16, p.23./Resumo PO03/

120. SANTOS, J.G. et al. Sazonalidade do teor de fluoreto em fontes de água de abastecimento no município de Nova Venécia, Espírito Santo. In: REUNIÃO ANUAL DA SBPqO, 20., 2003. Anais São Paulo, SBPqO, 2003. v.17, p.225./Resumo Pc123/

121. SÃO PAULO (Estado). Secretaria da Saúde. Resolução SS-250, de 15/08/1995. Diário Oficial do Estado de São Paulo, 16/08/1995, seção I, p.11.

122. SEPPÄ, L. et al. Caries ocurrence in a fluoridated and a nonfluoridated tow in Finland: a retrospective study using longitudinal data from Public Dental Records. Caries Research, v. 36, p.308-14, 2002.

123. SILVA, M.; REYNOLDS, E.C. Fluoride content of infant formule in Aust Dent J, v.41, n.1, p.37-42, 1996.

124. SILVA, M.F.A. Flúor sistêmico: aspectos básicos, toxicológicos e clínicos. In: KRIGER, L. Promoção de Saúde Bucal. São Paulo: ABOPREV, Artes Médicas, 1997. Cap.8, p.141-165.

125. SLADE, G.D. et al. Associations between exposure to fluoridated drinkimg water and dental caries experience among children in two Australian states. J Publ Hlth Dent, v.55, n.4, p.218-28, 1995. 
126. SOARES, M.D. do C.M. et al. Localidades com diferentes concentrações de flúor nas águas de consumo e sua relação com a prevalência de fluorose. Odontol Mod, v.22, n.4, p.18-21, out./dez. 1995.

127. SPADARO, A.C.C. et al. Avaliação do teor de fluoreto na água de abastecimento de cidades na região de Ribeirão Preto. Rev Odontol USP, v.4, n.3, p.252-5, 1990.

128. SPEARS, N.D. Los Angeles water should be considered fluoridated. J Public HIth Den, v.51, n.1, 1991.

129. TAVARES, P.G.; BASTOS, J.R.M. Concentração de flúor na água: cárie, fluorose e teor de flúor urinário em escolares de Bauru-SP. Rev Assoc Paul Cir Dent v.53, n.5, p.407-15, 1999.

130. TEN CATE, J.M.; FEATHERSTONE, J.D.B. Mechanistic aspects of the interactions between fluoride and dental enamel. Crit Rev Oral Biol, v.2, p.283-96, 1991.

131. TEN CATE, J.M. A review on fluoride, with special emphasis on clacium fluoride mechanisms in caries prevention. Eur J Oral Sci, v.105, p.461-5, 1997.

132. TEN CATE, J.M. Current concepts on the theories of the mechanism of action of fluoride. Acta Odontol Scand, v.57, p.325-9, 1999.

133. THYLSTRUP, A.; FEJERSKOV, O. Clinical appearence of dental fluorosis in permanent teeth in relation to histological changes. Community Dent Oral Epidemiol, v.6, p.329-37, 1978.

134. THYLSTRUP, A. Clinical evidence of the role of pre-eruptive fluoride in caries prevention. J Dent Res, v.69 (Special issue). p.742-50, 1990. 
135. Um Tesouro sob os Pés. Jornal da Cidade. Edição 175, 5 de novembro de 2003, p.42. Disponível na Internet. http://www.terramerica.com.br

136. VERTUAN, V. Redução de cáries com água fluoretada. Rev Gauch Odontol, v.34, n.6, p.469-71, 1986.

137. VIEGAS, A.R.P. Aspectos preventivos da carie dentária. São Paulo. Faculdade de Saúde Pública. USP. 1961.

138. VIEGAS, Y.; VIEGAS, A.R. Análise dos dados de prevalência de cárie dental na cidade de Campinas, SP, Brasil, depois de dez anos de fluoração da água de abastecimento público. Rev Saúde Pública, v.8, p.399-409, 1974.

139. VIEGAS, Y.; VIEGAS, A.R. Prevalência de cárie dental na cidade de Campinas, SP, Brasil, depois de quatorze anos de fluoração da água de abastecimento público. Rev Assoc Paul Cir Dent, v.39, n.5, p.372-82, 1985.

140. VIEGAS, A.R.; et al. Fluoretação da água de abastecimento público. Rev Assoc Paul Cir Dent, v.41, n.4, p.202-4, 1987.

141. VIEGAS, Y.; VIEGAS, A.R. Prevalência de cárie dental em Barretos, SP, Brasil, após dezesseis anos de fluoretação da água de abastecimento público. Rev Saúde Pública, v.22, n.1, p.25-35, 1988.

142. WERNER, A. Mapa dos bairros de Goiânia. O teor de flúor da cidade de Goiânia. Algumas análises -1997 a 1999. ROBRAC, v.8, n.25, p.49-51, 1999. 
143. WHITFORD, G.M.; PASHILEY, D.H.; REYNOLDS, K.E. Fluoride tissue distribution: short-term kinetics. Amer J Physiol, v.236, p.F141-8, 1979.

144. WHITFORD, G.M. Fluoride in dental products: safety considerations. J Dent Res, v.66, p.1056-60, 1987.

145. WHITFORD, G.M. The physiological and toxicologicol characteristics of fluoride. J Dent Res, v.69 (Special issue), p.539-49, 1990.

146. WHITFORD, G.M. Intake and metabolism of fluoride. Adv Dent Res, v.8, n.1, p.5-14, 1994.

147. WHITFORD, G.M. Effects of plasma fluoride and dietary calcium concentrations on $\mathrm{Gl}$ absorption and secretion of fluoride in the rat. Calcif Tissue Int, v.54, n.5, p.421-5, 1994.

148. WHITFORD, G.M. Fluoride toxicology and health effects. In: FEJESKOV, O.; EKSTRAND, J.; BURT, B.A. Fluoride in Dentistry. Copenhagen, Munksgaard. 2. ed. 1996. Cap.10, p.167-184.

149. WHITFORD, G.M. et al. Plaque fluoride concentrations are dependent on plaque calcium concentrations. Caries Research, v.36, p.25665, 2002. 
ABSTRACT 


\begin{abstract}
The importance of public water fluoridation for the prevention of dental caries has been scientifically recognized. The aim of this study was to evaluate the fluoride concentration of the public water supply of Bauru, SP, before and after the fluoridation, in different seasons. It was established a protocol for collecting water samples during 3 days in a week, every 3 months. Samples were collected at the Water Treatment Station and in 27 wells that supply the city, before and after fluoridation. In addition, samples were also collected in 63 points (houses), which were selected from a city map, corresponding to the 19 sections of supply, in order to represent all the distribution system. Samples were analyzed in duplicates, using an ion-sensitive electrode (Orion 9609), coupled to a potentiometer (Procyon, model SA 720), by adding $1 \mathrm{~mL}$ of TISAB to $1 \mathrm{~mL}$ of the water sample. Repeatability was checked in $10 \%$ of the samples and was higher than $90 \%$. No differences in the natural fluoride concentration in water were observed in the four different seasons. However mean fluoride concentrations found in the 297 samples collected in the Water Treatment Station and in the wells after fluoridation varied between 0.26 and $6.23 \mathrm{mg} \mathrm{F/L}$. For the 697 samples collected in the houses, the ranged was from 0.10 to $0.91 \mathrm{mg} \mathrm{F/L}$. Natural fluoride concentration in the water before fluoridation was constant, differently from fluoride concentration in the public water supply after fluoridation, which spanned a wide range. This indicates that the system of supply of Bauru does not maintain constant water fluoride levels.
\end{abstract}

Key-words: Fluoride, water fluoridation, prevention, vigilance. 
APÊNDICES 
APÊNDICE 1 
APÊNDICE 2 
APÊNDICE 3 
APÊNDICE 4 
APÊNDICE 5 